Universidade de São Paulo

Faculdade de Saúde Pública

\title{
TRABALHO E TEORIA SOCIAL NA SAÚDE COLETIVA: Uma análise da interpretação marxista sobre o trabalho em saúde
}

\section{HELTON SARAGOR DE SOUZA}

Tese apresentada ao Programa de Pós- graduação em Saúde Pública da Faculdade de Saúde Pública da Universidade de São Paulo para obtenção do título de Doutor em Ciências

Área de Concentração: Política, Gestão e Saúde Orientador: Prof. Dr. Áquilas Nogueira Mendes

São Paulo 
Trabalho e Teoria Social na Saúde Coletiva: uma análise da interpretação marxista sobre o trabalho em saúde

\section{HELTON SARAGOR DE SOUZA}

Tese apresentada ao Programa de Pósgraduação em Saúde Pública da Faculdade de Saúde Pública da Universidade de São Paulo para obtenção do título de Doutor em Ciências

Área De Concentração: Política, Gestão e Saúde

Orientador: Prof. Dr. Áquilas Nogueira Mendes

\section{São Paulo}


É expressamente proibida a comercialização deste documento, tanto na sua forma impressa como eletrônica. Sua reprodução total ou parcial é permitida exclusivamente para fins acadêmicos e científicos, desde que na reprodução figure a identificação do autor, título, instituição e ano da tese/dissertação. 
"Nada corrompeu mais o movimento operário alemão do que a convicção de Nadar a favor da corrente. Considerou o desenvolvimento técnico como o sentido da corrente. A partir daí, só precisou dar um passo para imaginar que o trabalho industrial representava uma conquista política. Às custas dos operários alemães, a velha ética protestante do trabalho celebrou, de uma forma secularizada, sua ressurreição. (...) Esta concepção de trabalho não se preocupa em saber em que medida os produtos deste trabalho servem aos próprios produtores, que não podem dispor deles. Só se preocupa com o progresso no domínio sobre a natureza, não com as regressões da sociedade".

Walter Benjamim, Teses sobre o conceito de história (1940) 
Souza, Helton Saragor: Trabalho e Teoria Social na Saúde Coletiva: uma análise da interpretação marxista sobre o trabalho em saúde. 174 pp. [Tese de Doutorado ]. São Paulo. Faculdade de Saúde Pública da Universidade de São Paulo. 2019

\begin{abstract}
RESUMO
A presente tese refere-se à pesquisa teórica acerca das principais obras de autores da corrente de interpretação marxista clássica do trabalho e da teoria social em saúde. Nesse sentido, os elementos centrais dessa corrente são abordados com referência a bibliografia de autores dos contextos intelectuais, francês e italiano. Depreende-se da pesquisa que a incorporação de outros meios intelectuais possibilitou $o$ desenvolvimento de uma teoria social em saúde original a partir de associações pluriparadigmáticas de teorias críticas de modernidade, na qual as contradições oriundas do domínio racional da natureza corpórea e seu meio na sociabilidade capitalista são elemento centrais do processo social de medicalização e mercantilização. A hipótese interpretativa desenvolvida aponta que duas principais teses da Escola de Frankfurt, a crítica ao progresso de Walter Benjamim e a crítica a racionalidade técnica instrumental de Adorno e Horkheimer, são basilares na elaboração da teoria social em saúde constituidora do campo interdisciplinar da saúde coletiva. Na perspectiva de balanço crítico da interpretação marxista, destacamos a transição analítica da prática médica à teoria do processo de trabalho em saúde com identificação de contribuições e limites para a apreensão do trabalho das ocupações em saúde no processo contemporâneo de complexificação do trabalho e da relação social em saúde.
\end{abstract}

Descritores: Saúde Coletiva; Trabalho em Saúde; Teoria Social em Saúde; Modernidade; Escola de Frankfurt; 
Souza, Helton Saragor: Work and Social Theory in Collective Health: an analysis of the Marxist interpretation on health work 174 pp. [Phd Thesis]. São Paulo. Faculdade de Saúde Pública da Universidade de São Paulo. 2019

\begin{abstract}
The present thesis refers to the theoretical research about the main works of authors of the current of classic Marxist interpretation of work and social theory in health. In this sense, the central elements of this chain are approached with reference to the bibliography of authors from the intellectual contexts, French and Italian. It follows from the research that the incorporation of other intellectual means enabled the development of an original health social theory from pluriparadigmatic associations of critical theories of modernity, in which the contradictions stemming from the rational domain of corporeal nature and its environment in capitalist sociability are central elements of the social process of medicalization and commodification. The interpretative hypothesis developed suggests that two main theses of the Frankfurt School, the criticism of Walter Benjamim's progress and the critique of instrumental technical rationality of Adorno and Horkheimer, are fundamental in the elaboration of the social health theory that constitutes the interdisciplinary field of collective health. From the perspective of a critical balance of Marxist interpretation, we highlight the analytical transition from medical practice to the theory of the health work process with the identification of contributions and limits for the apprehension of the work of occupations in health in the contemporary process of work and social relationship in health.
\end{abstract}

Keywords: Collective Health; Work Health; Social Theory and Health;Modernity; Frankfurt School of Critical Theory 


\section{SUMÁRIO}

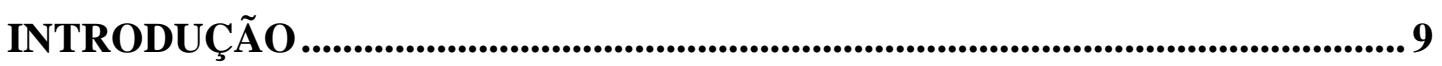

\section{CAPÍTULO 1: A INTERPRETAÇÃO MARXISTA CLÁSSICA SOBRE O TRABALHO EM SAÚDE NO CAMPO DA SAÚDE COLETIVA....................... 19}

1.1 O Cuidado Médico na Crítica À Medicina Preventiva: O Legado de Sérgio AROUCA.

1.1.1 Medicina e Sociedade: O Cuidado como Ponto de Partida ...................20

1.1.2 Capitalismo Monopolista e Trabalho Médico ……………………….....24

1.2 Medicina Como Prática Social Sob o Capitalismo e o Mercado de Trabalho Médico no Brasil: A Herança de Cecília Donnangelo À SaÚde Coletiva. .... 26

1.2.1 O Assalariamento do Profissional Médico no Mercado de Trabalho no Brasil

1.3 O Trabalho em Saúde na Perspectiva Ontológica e na Forma Histórica do CAPITAlismo na obra de Ricardo BRUNo MENDES-GonÇALVES 35

1.3.1 A Análise da Organização do Trabalho nos Serviços e a Acepção Ampla de Tecnologia .37

1.3.2 A Fundamentação Ontológica e Histórica do Trabalho ................................38

1.3.3 O Trabalho em Saúde na Forma Histórica do Capitalismo............................44

1.3.4 A Teoria das Necessidades em Saúde ..........................................................46

1.3.5 Conformação Técnica do Processo de Trabalho e as Necessidades Necessárias do Capitalismo. .51

1.3.6 A Práxis em Saúde: A Conformação de Novos Processos de Trabalho e Modelos de Atenção. .53

1.4 A Integralidade do Trabalho Médico na Transição da Medicina TECNOLÓGICA NA CONTRIBUiÇão de LILIA BLIMA SCHRAIBER. 55

1.4.1 A Pesquisa: A História pela perspectiva dos Agentes da Práticas .57

1.4.2 A Autonomia como Categoria Chave da Interpretação da Prática Médica60

1.4.3 O Trabalho Coletivo em Saúde e a Autonomia como Estratégia Política: A Resistência Médica. 64

CAPÍTULO 2: LEITURAS CRÍTICAS DA MODERNIDADE E TEORIA SOCIAL EM SAÚDE .67 
2.1 A Teoria Social em Saúde nos Departamentos de Medicina Preventiva de SÃo Paulo: As Relações dos Contextos Intelectuais entre Brasil, Itália E

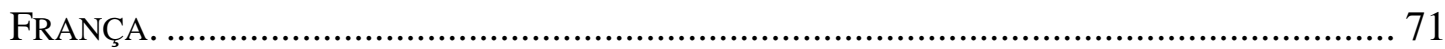

2.2 A RaCionalidade Moderna Em Debate na SAÚde Coletiva .......................... 74

2.3 A CRÍtica a Racionalidade Científica e a Medicina no Brasil: Natural,

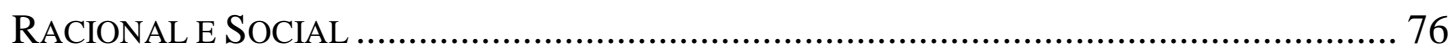

2.4 MODERNIDADE: ESPAÇO PÚBLICO E EPIDEMIOLOGIA …........................................ 78

2.5 Biopoder, Clinica E MercantilizaÇão: A ReCEPÇÃo MARXista dA

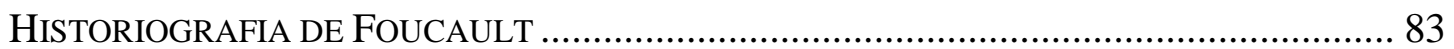

2.6 A RESSIGNIFICAÇÃO DA FILOSOFIA CANGUILLEM …............................................ 90

2.7 O ENCONTRO DA CRÍTICA MARXISTA À IDEOLOGIA DO PROGRESSO COM AS TEORIAS

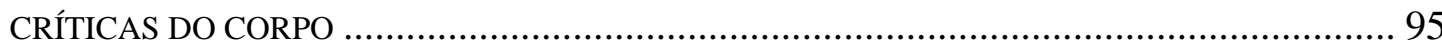

2.8 Teses Frankfurtianas: A Crítica ao Progresso e a Racionalidade TÉcnica

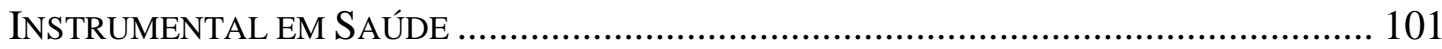

2.8.1 A Critica à Ideologia do Progresso na História da Medicina de Laura Conti 102

2.8.2 A Teoria Crítica no Centro da Radicalidade Anti-Moderna nas Relações de Saúde de Illich 107

\section{CAPITULO 3: BALANÇO CRÍTICO DA INTERPRETAÇÃO MARXISTA SOBRE O TRABALHO EM SAÚDE NO BRASIL 118}

3.1 Da Centralidade da Prática Médica À TeOria do Processo de Trabalho em SAÚdE: O SENTIDO SOCIAL DA COMPLEXIDADE 120

3.1.1 O Sentido Social da ComplexificaÇão do Trabalho Médico E das OCUPAÇÕES EM SAÚDE.

3.1.2 Proletarização Peculiar dos Médicos no Brasil e as OcupaÇões em SAÚDE

3.2 Trabalho, Estado Nacional E SeRviços de Saúde 134

3.3 Perspectivas ContemporÂneas da InTERPREtação MarXista do Trabalho EM SAÚDE 138

CONSIDERAÇÕES FINAIS .................................................................................. 150

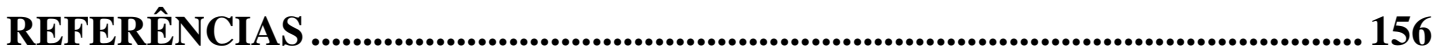




\section{SIGLAS UTILIZADAS}

ABRASCO - Associação Brasileira de Saúde Coletiva

Cebes - Centro Brasileiro de Estudos de Saúde

CLT - Consolidação das Leis Trabalhistas

OSS - Organização Social de Saúde

SUS - Sistema Único de Saúde

UBS - Unidade Básica de Saúde

USP - Universidade de São Paulo

Unicamp - Universidade Estadual de Campinas 


\section{Introdução}

Na presente tese, destacamos as análises acerca do trabalho médico e das práticas em saúde realizadas por autores fundamentais no período entre as décadas de 1970 à 1990. O estudo do trabalho das ocupações em saúde ao lado da crítica ao modelo da medicina comunitária ou preventiva fundaram o campo da saúde coletiva, ambos os objetos se inseriam na análise histórica geral da relação entre capitalismo e saúde na sociedade brasileira. Em nossa abordagem, selecionamos as obras e autores que se enquadravam nos parâmetros definição dos construtores da saúde coletiva (Hochmann e Nunes, 2015), ou melhor, autores que contribuíram decisivamente com sua produção teórica acerca do trabalho das ocupações em saúde inseridos no campo da saúde coletiva no Brasil.

As reflexões fundamentais sobre o trabalho em saúde compõe tanto o repertório dos autores considerados pioneiros na constituição do pensamento social crítico em saúde, Maria Cecília Donnangelo com as obras: Medicina e Sociedade: o médico e seu mercado de trabalho (1975) e Saúde e Sociedade (Donnangelo e Pereira, 1976); e O Dilema Preventivista: Contribuição para a compreensão e crítica da medicina preventiva de Sergio Arouca (2003) quanto essa compreensão prossegue e é desenvolvida por autores vinculados à escola de pensamento forjada por Donnangelo, a teoria do processo de trabalho em saúde (Mendes-Gonçalves, 1994) com as produções de Ricardo Bruno Mendes Gonçalves: Medicina e História: Raízes Sociais do Trabalho Médico (1979); Tecnologia e Organização Social das Práticas de Saúde: Características Tecnológicas do Processo de Trabalho na Rede Estadual de Centros de Saúde de São (1994) e Práticas de saúde: processos de trabalho e necessidades $(1992,2017)$ e da primeira fase da obra de Lilia Blima Schraiber analisamos a obra: O Médico e seu Trabalho. Limites da liberdade (1993), em nossa apreciação, a última obra é um ponto de chegada sobre o trabalho médico na escola de pensamento fundada por Cecília Donnangelo. Denominaremos o conjunto dessa produção teórica como interpretação marxista clássica do trabalho em saúde.

Sintetizamos a principal questão desenvolvida na pesquisa do seguinte modo: como pressupostos epistemológicos tão distintos constituem uma teoria social em saúde que baliza a constituição da saúde coletiva e analisa o trabalho em saúde? Dessa problemática chave, desdobra as interrogações correlacionadas: Quais eram os debates de 
suas referências teóricas? Qual era a conformação de seus meios intelectuais. O objetivo da tese é a leitura crítica da interpretação marxista clássica sobre o trabalho das ocupações em saúde, todavia, a análise do trabalho não se trata de um mero recorte empírico nesses autores, trata-se de apreciação de uma relação social fundamental na totalidade histórica. Logo, deve se explicitar os pressupostos dos constructos teóricos por meio da discussão detalhada dos pressupostos teóricos e paradigmáticos das obras.

Entendemos a saúde coletiva como campo de conhecimentos interdisciplinares e de práticas multiprofissionais oriundo da emergência de departamentos e programas de pós graduação de medicina preventiva e social entre as décadas de 1960 e 1970. As movimentações acadêmicas pretendiam a compreensão mais ampla e social do processosaúde doença a partir da recepção crítica da medicina preventiva (Leavel e Clarck, 1962), refutando a concepção exclusivamente fisiológica individual com vistas a determinação social do processo saúde e doença. Bem como, visava o direcionamento das práticas existentes e conformação de novas para a prevenção e promoção em saúde. Nesse contexto, a criação das entidades Associação Brasileira de Pós-Graduação em Saúde Coletiva (Abrasco); e do Centro Brasileiro de Estudos de Saúde (Cebes) na década de 1970 e a realização da $8^{\text {a }}$ Conferência Nacional de Saúde são marcos de constituição do campo no âmbito acadêmico, de aplicações nos serviços de saúde e político na proposição de um sistema público de saúde na realidade brasileira (Vieira-da-Silva LM, Paim JS, Schraiber LB, 2014; Vieira-da-Silva, 2015).

O exercício de retomar autores fundacionais ou construtores da saúde coletiva não é novo, a abertura de seções especiais destinadas a tal fim em revistas do campo; dissertações e teses; compilações e reedições de obras estão presentes nos últimos quinze anos. Com especial destaque para o projeto da revista Ciência e Saúde Coletiva: Construtores da Saúde Coletiva (Hochmann e Nunes, 2015) que realizou uma coletânea plural de personagens nacionais e estrangeiros, acadêmicos ou expoentes das práticas de saúde com diversas formações, perspectivas temáticas e teóricas na constituição do campo da saúde coletiva ${ }^{1}$. Também realçamos a edição da tese de Arouca na edição em

\footnotetext{
${ }^{1}$ Nos autores abordados em diversos artigos estão: Juan Cesar Garcia; Samuel Pessoa; Ricardo Bruno Mendes-Gonçalves; Rodolfo dos Santos Mascarenhas; Maria Cecília Donnangelo; Izabel dos Santos; Guilherme Rodrigues da Silva; Mario Magalhães; Walter Leser; Joaquim Alberto Cardoso de Melo; Giovanni Berlinguer; Maria Cecilia Puntel de Almeida; Hernán San Martin.
} 
livro O Dilema Preventivista: Contribuição para a compreensão e crítica da medicina preventiva em 2003 com contribuições de diversos comentadores, referente aos capítulos da obra. Destacamos também, a análise do seu referencial marxista na dissertação: As Raízes do Pensamento Econômico em Saúde no Brasil: A concepção do trabalho médico e a produção na obra o dilema preventivista de Sergio Arouca (Emerenciano, 2017). Comentadores ressaltam o caráter inaugural da obra de Donnangelo (Nunes, 2008) e as suas diversas contribuições para a saúde coletiva (Schraiber e Mota, 2015), assim como, a compilação em livro de aulas da autora em Social na Epidemiologia: um legado de Cecília Donnangelo (Carvalheiro, Heimann e Derblic, 2014). Concernente a MendesGonçalves, a coletânea de textos de diversas obras no livro Saúde, Sociedade e História em 2017 com contribuições temáticas, bem como, artigos que sintetizam sua produção teórica Ayres (2015). Da mesma maneira, as diversas abordagens teóricas sobre o trabalho em saúde no campo da saúde coletiva foram expostas em Peduzzi (2007) e em Schraiber (2008).

Nesse sentido, a diversidade do campo da saúde coletiva também se expressa em diversas correntes teóricas sobre o trabalho em saúde. Inicialmente, esboçamos panorama do conjunto dessa literatura a fim de diferenciações e justificativa de concentração de esforços na análise de uma corrente específica, a interpretação marxista clássica do trabalho em saúde. De modo introdutório e distante de análise definitiva e, propomos um painel das principais contribuições, as convergências e as divergências entre as abordagens presentes no campo da saúde coletiva. Os critérios de diferenciação foram os pressupostos teóricos e metodológicos, assim como, as prioridades de investigação dos autores. Os autores selecionados discutiram temáticas mais amplas do que o objeto de estudo da presente tese, o leque temático influencia consideravelmente a análise sobre o próprio trabalho. Nosso propósito, é meramente situar o conjunto das obras ${ }^{2}$.

Nessa perspectiva, agrupamos autores distintos em linhagens teóricas. Essa classificação não é rígida, pois o debate é dinâmico e alguns autores transitam entre as abordagens, por alteração do entendimento ou convencimento de outro paradigma, sínteses ou diálogos com associação de paradigmas teóricos distintos entre outras razões,

\footnotetext{
2 A teorização sobre o conjunto dessas interpretações a produção de considerações a partir das contribuições, de possíveis potencialidades e limites, e sobretudo, do embate de perspectivas dos autores e de analise exaustiva de cada corrente teórica ficará para outros empreendimentos de pesquisa.
} 
logo, a classificação da produção teórica não é estanque. De forma diferenciada nessas correntes, está presente a problemática inicial do campo da saúde coletiva acerca do trabalho: qual é a realidade do trabalho para a conformação dos serviços de saúde necessários à população brasileira? E como transformar e enfrentar determinados impasses na sociedade brasileira?

Propomos a classificação de quatro correntes teóricas do trabalho em saúde: 1interpretação marxista clássica; 2- teoria da ação comunicativa; 3- propositoras de racionalidades assistenciais e modelos de gestão alternativos; e 4- recursos humanos em saúde e gestão do trabalho.

A interpretação marxista clássica formula a partir das relações entre os serviços de saúde e a sociedade capitalista, mais precisamente, sobre três dimensões chaves: os serviços de saúde como uma espécie de mercadoria; na relação de exploração entre classes na relação social em saúde; o processo moderno da medicalização do social. Dentro do rol dos temas, a apreciação do caráter do Estado no Brasil está presente, consequentemente, a caracterização contraditória da política de saúde como conquista resultante da luta de classes e funcional à recomposição física da força de trabalho para a atividade produtiva. Subdividimos esse matiz teórico em três variações:

A interpretação clássica corresponde aos seguintes autores: Donnangelo, 1975 e 1976, Arouca, 2003, Mendes-Gonçalves, 1979, 1985 e 1992; Schraiber, 1993; Gomes, 2007 e 2010; Nogueira e Gomes, 2012³ . Também situadas nesse entendimento de crítica marxista, identificamos a abordagem do processo de trabalho, a divisão social do trabalho e a racionalização do trabalho das categorias da enfermagem (Almeida, 1986 e 1997; Melo, 1986; Pires 2007, 2009a, Pires et al., 2004 e 2010; Queiroz e Salum, 1996); as contribuições da saúde do trabalhador que analisa o conjunto da saúde dos trabalhadores em diversos segmentos profissionais e não necessariamente a condição do trabalho das ocupações em saúde (Lacaz, 1983 e 1996).

A segunda corrente identificada remete aos autores da teoria da ação comunicativa no trabalho em saúde. Nessa perspectiva, o processo de trabalho das

\footnotetext{
${ }^{3}$ Determinadas produções de Roberto Passos Nogueira de caráter teórico e de Rogério Miranda Gomes, embora, compartilhem do referencial teórico da interpretação clássica não foram analisadas por questões de exequibilidade.
} 
profissões em saúde desenvolver-se-ia de forma análoga aos demais processos de trabalho nos serviços com a incorporação do desenvolvimento científico e tecnológico, o peso da grandeza do saber no trabalho é ressaltado. Visto a peculiaridade do objeto e da relação entre os sujeitos/usuários e os sujeitos/agentes do trabalho, logo, o trabalho em saúde seria reflexivo e poderia ser interpretado sob duas dimensões: ação produtiva como atividade teleológica dotado de racionalidade e a comunicação como interação social segundo a teoria da ação comunicativa habermasiana (Ayres, 1996 e 2002; Peduzzi, 1999, 2001 e 2007; Peduzzi e Anselmi, 2002; Schraiber et al, 1999) ${ }^{4}$. Essa corrente tem sua constituição original na teoria do processo de trabalho em saúde e não caracteriza que a assimilação do paradigma habermasiano configure uma ruptura do entendimento da interpretação marxista clássica.

A terceira corrente desenhada, denominamos como propositoras de racionalidades assistenciais e modelos de gestão alternativos no trabalho em saúde. Desse modo, a subdividimos em duas perspectivas. A primeira é exposta pela teorização de Campos (1997, 1998 e 2003) que propõe novo método de gestão de organização do trabalho em equipe para a produção em saúde alternativo à organização/gestão do trabalho taylorista. Esse novo método se basearia na gestão colegiada, democrática, centrada nas equipes de saúde com apoio matricial. Essa forma de organização teria duplo horizonte. Por um lado, asseguraria o cumprimento do objetivo primário de cada organização produzir saúde, educar etc; e por outro lado, ao mesmo tempo, permitiria e estimularia os trabalhadores a ampliar sua capacidade de reflexão, de cogestão e, em decorrência, de realização profissional e pessoal. Em suma, consistiria em funcionamento democrático, mas ao mesmo tempo produtor de compromissos e responsabilidades bem definidos que resultariam em modelo alternativo de clínica ampliada e compartilhada (Campos, 1997, 1998, 1999, 2003 e 2010; Campos e Amaral, 2007; Almeida e Zanoli, 2011).

A segunda perspectiva da proposição de racionalidades alternativas é exposta na contribuição de dois autores Merhy e Cecílio (1991). Os autores definem o trabalho em saúde, por suas peculiaridades, como singular em relação aos demais processos

\footnotetext{
${ }^{4}$ Como forma de ilustração sobre o debate acerca de enquadramento de autores e perspectivas, Ayres (2002) e Peduzzi (2007) apontam a trajetória intelectual de como Mendes-Gonçalves a partir das premissas marxianas desenvolve a aproximação com a teoria da ação comunicativa de Habermas.
} 
produtivos. Merhy formula a cartografia da micropolítica do trabalho vivo em ato e explora dois pressupostos como fundamentação para a sua singularidade: 1) predomínio do trabalho vivo sobre o trabalho morto; 2) realização no encontro do trabalhador e do usuário. Na saúde, o trabalho vivo em ato em oposição aos outros trabalhos realizados são processos vivo-centrado e tem grau de liberdade significativo. Essa dinâmica comporta a criatividade do trabalhador e a ação do usuário como sujeitos instituintes que podem abrir fissuras nos processos produtivos instituídos, logo a proposição de linhas de fuga aos modos hegemônicos na gestão do trabalho (Merhy, 2007). O autor refere-se ao conjunto de conhecimentos teóricos e práticos associados à produção, logo, o termo não é utilizado em acepção restrita de referência somente a equipamentos. Merhy classifica e subdivide as tecnologias nas categorias: dura, dura-leve e leve.

De acordo com Cecílio, o primeiro aspecto do trabalho em saúde é a produção do cuidado e advoga que a partir das necessidades de saúde (2006) é possível caracterizar o trabalho e sua especificidade. Desse modo, o autor propõe o desenvolvimento da cartografia das necessidades em saúde e para a construção da política de saúde. Diante do aumento da institucionalização, da especialização e fragmentação, o autor propõe a constituição do trabalho multiprofissional com atenção que existem várias dimensões do cuidado, mas todas devem ter a capacidade de escuta singular de cada pessoa em contraste a homogeneização dos protocolos (Cecílio, 1994, 1999 E 2012; Cecílio e Lacaz, 2012; Cecílio e Mendes 2004).

A quarta corrente desenhada refere-se à pesquisa acerca dos recursos humanos em saúde e gestão do trabalho (Nogueira, 1983, 1985, 1997 e 2002; Paim, 1994; Pereira, 2004). Sinteticamente, essa corrente tem como foco temas como o emprego e a gestão do trabalho se vinculam com a concretização e a execução de serviços, consequentemente, do SUS (Machado, 1995). Desse modo, os autores priorizam temas como a formação dos profissionais em saúde e as questões pertinentes as profissões, reflexões sobre qualificação, a mensuração do emprego nas três origens: o sistema público, a gestão terceirizada e o sistema privado, a distribuição desses profissionais pelo território nacional, a constituição de carreiras, a dinâmica do mercado de trabalho etc. (Maciel Filho e Pierantoni, 2004) ou seja, a política de recursos humanos. Os autores chamam a atenção para que os recursos humanos em saúde fossem prioridade do Estado (PIERANTONI, 2001) e quais são as consequências pela falta de priorização (MACHADO, 2011). Essa produção tem caráter crítico e se associa à produção teórica das demais correntes. Essa 
corrente também se aproximou da perspectiva da sociologia das profissões em saúde (Friedson, 2009) e se dedicou ao entendimento dos perfis de categorias profissionais como médicos e enfermeiros na realidade brasileira (Cofen/Fiocruz, 2017 Machado, 1996; Machado, Mh; Vieira, Als; Oliveira 2012.)

A explanação panorâmica sobre a elaboração teórica de diversos autores com pressupostos teóricos e objetos heterogêneos está sujeita há alguns riscos, o primeiro seria a análise parcial e incipiente desprovida de conteúdo relevante, em síntese, desenvolverse-ia um "catálogo" das diversas contribuições; o segundo seria o estabelecimento apriorístico de uma concepção como correta e, consequentemente, a desqualificação das demais teorias de constructos teóricos diversos, essa posição configuraria em proselitismo disfarçado. Escolhemos a concentração na análise na interpretação marxista clássica sobre o trabalho em saúde, porque a pesquisa acerca do trabalho médico e das ocupações em saúde nos autores ao ser levada à ultima estância forçou o empreendimento sobre os fundamentos e traços constituintes da própria teoria social em saúde.

Desse modo, a hipótese interpretativa da tese advoga que mesmo de modo implícito nas contribuições dos autores marxistas na constituição da saúde coletiva está presente uma teoria social em saúde baseada na associação de paradigmas sociais críticos da modernidade. Obviamente, não se reserva ao esforço do empreendimento limitado da tese acadêmica, o conjunto de problemáticas e aspectos multifacetados decorrentes da relação social moderna com o corpo alicerçado na racionalidade científica e na sociedade capitalista entre outros. A emergência da modernidade com a conformação de três séculos XVI a XVIII na Europa Ocidental e posterior influência e condicionamento na realidade brasileira abrange uma amplitude múltipla. Dessa maneira, o fio condutor da análise pode ser sintetizado nos seguintes termos: o desenvolvimento teórico dos autores da interpretação marxista clássica se basearam principalmente na recepção das produções teóricas no contexto italiano e francês na década de 1960 que analisavam seus objetos a partir de teorias críticas, todavia, distintas da modernidade. Esse "preâmbulo" teórico altera o patamar da discussão sobre a teoria social em saúde e o trabalho das ocupações em saúde, assim como, oferta a crítica elementos mais profundos sobre a realidade contemporânea e seus objetos de pesquisa.

Em nossa perspectiva, os pressupostos acerca da modernidade presente nos autores basilares da teoria social em saúde continuam significativamente relevantes e 
produtivas a interpretação da vida social sob a racionalidade moderna e suas contradições nos aspectos políticos e intelectuais. Indubitavelmente, vivemos na contemporaneidade tendências de complexificação em todas as esferas da experiência individual, familiar, laboral, cultural, religiosa e na relação com corpo e sua natureza, todavia, os fundamentos da modernidade não ficaram datados à sua consolidação no século XVIII e ainda estão vivos no cotidiano.

A presente tese mira um debate e "acerta" dois alvos no diálogo com a atual produção corrente das ciências sociais em saúde, primeiramente, a reflexão de objetos a partir das teorias sociais clássicas estão secundarizadas, seja pela adesão as teorias sociais contemporâneas ou pela maior presença dos estudos antropológicos e dos diversos eixos de pesquisa requerido pelo conjunto da saúde coletiva. Tal apreciação pode ser confirmada com a observação da programação principal, eixos temáticos e maioria dos trabalhos apresentados nos Encontro de Ciências Sociais em Saúde da ABRASCO (Associação Brasileira de Saúde Coletiva) nos últimos anos (Abrasco, 2013 e 2016). Da mesma maneira, a discussão da teoria social em saúde permanece restrita aos textos iniciais do campo, especificamente, a constituição da clínica ou as formas de medicina social na perspectiva focaultiana e não como teoria para apreensão contemporânea na maioria dos programas de pós-graduação da saúde coletiva no país. Outro ponto de debate é sobre a abordagem do trabalho, majoritariamente, a categoria ou a integralidade do trabalho em suas múltiplas expressões não são objetos correntes para análise sociológica em saúde, sendo que a maior parte das análises sobre o tema está vinculado à discussão de recursos humanos ou gestão e política do SUS (Sistema Único de Saúde) não propriamente uma abordagem sociológica do trabalho e da saúde ${ }^{5}$. Outro aspecto que colabora para tal situação refere-se à fragmentação nas multiplicidades das categorias profissionais e sua pluralidade característica na dinâmica da produção acadêmica,

O percurso metodológico adotado para a interpretação dos autores seguiu por dois caminhos: O primeiro refere-se à revisão de literatura que selecionou as obras que se inserem nos parâmetros do que denominamos como interpretação marxista clássica sobre o trabalho em saúde e realizou a leitura imanente, a valorização dos termos dos autores

\footnotetext{
${ }^{5}$ Discussão mais presente nos congressos de Política e Gestão da ABRASCO do que no Encontro de Ciências Sociais (Abrasco, 2013 e 2017)
} 
inseridos no conjunto de suas obras. O segundo caminho diz respeito ao estudo de fontes em seus ambientes intelectuais e políticos no esforço de desvendar as associações teóricas desenvolvidas a partir das interpretações sociais da modernidade nos autores utilizados como referências paradigmáticas. De modo associado, a leitura procedeu a pesquisa de obras fundamentais de referência dos autores selecionados, oriundos dos ambientes intelectuais francês e italiano. Tal encaminhamento de análise de fontes possibilitou maior entendimento dos pressupostos teóricos e de identificação das associações paradigmáticas dos autores.

As escolhas metodológicas objetivaram, por um lado, a fiel exposição do pensamento dos autores não incorrendo em reducionismo de suas reflexões, do outro lado, a agregação acerca das obras de referência enriqueceram a compreensão e relevância dos autores. Desse modo, a compreensão das obras foi um esforço inegável, ao passo que, tal elucidação necessariamente transita nas relações do conhecimento produzido e o contexto social de inserção. Contudo, a prioridade do enfoque se concentra nos desenvolvimentos acerca do trabalho em saúde na relação social em saúde, pois não se trata de uma tese característica da sociologia do conhecimento. Desse modo, esboçamos uma história das ideias secundariamente, todavia não como objetivo central da presente tese.

A reflexão desse processo de assimilações e integrações dos conceitos e categorias teórica em ambientes intelectuais distintos altera a apreciação mais comum dos autores do campo da saúde coletiva, nas quais Arouca $(2003)$ e Donnangelo $(1975,1976)$ são o ponto de partida da conformação das teorias. Em nosso empreendimento os autores "inaugurais" do campo integram a produção crítica internacional e suas associações das teorias formuladas em outros contextos à realidade brasileira. A compreensão crítica do meio intelectual associado aos objetivos teóricos e político dos autores auxiliam a compreensão de suas obras, escolhas e construções teóricas e suas apostas. Bem como, as chaves interpretativas das obras, auxiliam para mensurar a relevância de teoria para compreensão contemporânea do real e dos temas das relações sociais em saúde. Em outros termos, a compreensão das raízes da teoria social em saúde a partir dos seus fundamentos teóricos nos possibilita ir além de seus próprios desenvolvimentos.

A tese dividir-se-á em três partes: a primeira, apresentaremos a síntese dos autores da bibliografia sobre o trabalho da interpretação marxista clássica no campo da saúde coletiva; a segunda abordará as reflexões presentes sobre a modernidade no campo da 
saúde coletiva e do fundamentos da teoria social em saúde com ênfase aos elementos precedentes acerca da modernidade em saúde; na terceira seção, realizamos um balanço das contribuições e limites da interpretação marxista clássica para a apreensão contemporânea. 


\section{Capítulo 1: A Interpretação Marxista Clássica sobre o Trabalho em Saúde no Campo da Saúde Coletiva}

Os autores da interpretação marxista do trabalho em saúde se dedicaram a análise do trabalho médico vinculado aos temas da formação social capitalista no Brasil, da mesma forma, analisaram a associação do capital e do Estado nacional na conformação dos serviços de saúde no país do ponto de vista do trabalho, e tinham como pressuposto a caracterização da contradição da reprodução do modo de produção capitalista e a expansão da medicalização.

No conjunto dos autores, o compartilhamento de referências teóricas críticas se combina com estudo de objetos diferentes e com preocupações diversas. Sob essa ótica, identificamos complementaridades e diferenças, e também, limites sujeitos à crítica que somente o estudo criterioso pode proporcionar, não obstante, destacamos a presença de formulações fundamentais nas obras. Nesse sentido, a abordagem da linhagem marxista clássica sobre o trabalho em saúde nos oferece elementos para apreensão do real, mais do que o mero resgate dos autores, suas posições foram incorporadas parcialmente por todas as correntes interpretativas do trabalho em saúde e são produções originais interpretativas da transição presente na relação das instituições de saúde e o estado brasileiro, com especial destaque acerca das práticas de saúde e os aspectos concernentes o trabalho médico: considerações sobre o funcionamento das regras de mercado, o assalariamento, a autonomia profissional dos médicos; a exploração e a alienação do trabalho das ocupações de saúde e a proposição de novos modelos.

\subsection{O Cuidado Médico na Crítica à Medicina Preventiva: O Legado de} Sérgio Arouca

Em O dilema preventivista: contribuição para a compreensão e crítica da medicina preventiva (2003), Arouca se dedica centralmente a análise da formação discursiva foucaultiana da medicina preventiva associando ao conceito de ideologia proveniente da teoria crítica de Marx. Dessa maneira, problematiza o paradigma da História Natural das Doenças e propõe a constituição do paradigma do contexto históricosocial. Em seus termos realiza "uma abordagem materialista da arqueologia" (Arouca, 2003, p.84).

Na crítica à obra de Leavel e Clarck (1962), Arouca destaca o caráter ideológico da constituição da Medicina Preventiva, visto que se trata sobretudo de uma reorganização dos conhecimentos anteriores, que se propõe a combater e substituir a 
ideologia anterior da Medicina Curativa para tal tarefa. Também, problematiza a ineficiência na resolução dos problemas de saúde populacionais e a excessiva especialização biomédica do modelo curativo. A partir da premissa que a doença não é condição estática, mas que essa segue um percurso previsto na história natural, essa deve ser interrompida o quanto antes de acordo com as possibilidades, assim como, as medidas preventivas devem se ampliar para todos os indivíduos tanto doentes quanto sadios, nesses últimos deve intervir nos hábitos para a promoção da saúde. Essa nova postura reivindica a formação humanística na educação médica.

$\mathrm{Na}$ crítica ao preventivismo, o autor aponta os limites teóricos dessa concepção que ainda mantém a lógica individualista e a redução biomédica das condições sociais e históricas de saúde, logo, o paciente continua como suporte da doença e a dinâmica reduzida ao paradigma biomédico, sendo os aspectos histórico-sociais assemelhados à externalidades. Posteriormente, esse debate ganhou outros termos no campo da saúde coletiva: a crítica ao modelo biomédico e as diversas aplicações da teoria da determinação social do processo saúde e doença. Não obstante, o destaque da crítica ampla aos pressupostos do modelo preventivista, o autor expõe a necessidade "Analisar a articulação da medicina em geral com a sociedade" (Arouca, 2003, p.219) no capítulo Medicina Preventiva e Sociedade. Para tal tarefa analisa o trabalho médico como fundamento dessa articulação.

\subsubsection{Medicina e Sociedade: O Cuidado como Ponto de Partida}

Arouca define o cuidado médico como a mais simples unidade de toda medicina e que o cuidado acontece em uma relação social daquele que cuida e daquele que é cuidado. A reflexão de Arouca construiu posições fundamentais que foram incorporadas na produção teórica posterior por todos os matizes teóricos, por exemplo, a definição do cuidado como o processo de trabalho do médico, a natureza relacional entre o médico e o paciente. Posto que, o processo de trabalho médico ou das demais profissões em saúde não constituem objeto principal da tese de Arouca, a conceituação da relação social do cuidado é uma pedra angular de toda bibliografia do trabalho em saúde, pois esse aspecto relacional ou interativo entre o trabalhador dos serviços de saúde ( não exclusivamente o médico) e o sujeito atendido é elemento basilar para a construção de teorização plural e posições díspares embora partam da relação fundamental apontada por Arouca. Para o autor essa relação de cuidado é desigual e a concentração do saber é pressuposto, por tal 
motivo, os médicos conformariam um grupo privilegiado na relação social de cuidado. Historicamente, Arouca destaca a relação capitalista no cuidado médico, na qual médico e paciente estão em relação de troca:

(...) As leis que regulam a divisão do trabalho operam coma força irresistível das leis naturais, de tal forma que os médicos e pacientes encontram-se em relação de troca, em que um é portador de necessidades e o outro de conhecimentos. Mas o que o primeiro recebe não é o conhecimento, e sim o cuidado, forma instrumental deste conhecimento monopolizado (Arouca, 2003, p.220)

Na perspectiva do autor, não existe cuidado apartado das relações capitalistas de troca que estaria no mesmo patamar de força das relações da natureza, na qual um sujeito que necessitaria de cuidado e outro trocaria o cuidado oriundo do conhecimento monopolizado na qual o médico intercambiam na divisão social do trabalho. A partir dessa definição, o autor define o processo de trabalho médico conforme a interpretação de Althusser (1971) como o cuidado em si, composto tanto pela dimensão técnica quanto social, Arouca diz:

Entendendo processo de trabalho como um processo de transformação, o cuidado médico como tal está centrando sobre seu objeto, o homem, em suas dimensões biológicas e psicológicas, cujo resultado é a manutenção, recuperação e transformação de determinados valores vitais. Portanto, o cuidado é o próprio processo de trabalho de agentes que monopolizavam o conhecimento e habilidades para esta atividade, utilizando instrumentos determinados (Ibid, 2003,p.220)

Seguidamente, o autor desenvolve o cuidado em saúde como mercadoria, na qual se subentende o valor de uso na intervenção sobre as necessidades humanas vitais e na relação social e histórica do valor. A partir dessa ideia-base, Arouca discorrerá sobre as características sociais do cuidado médico no capitalismo: o cuidado esse seria simultaneamente unidade de produção e consumo ${ }^{6}$ e implicaria três tipos de valores: valor de troca, valor (uso e troca) e valores socialmente atribuídos aos valores vitais. Nessa perspectiva, o cuidado médico está inserido no processo de trabalho e, simultaneamente, atende as necessidades vitais criadas nos "modos de andar a vida", formulação de Canguillem (2009), envolto em relações sociais e históricas (Arouca, 2003, p.221).

6 Parte da caracterização de Arouca sobre o trabalho médico refere-se às características da atividade econômica de serviços relacionais, logicamente, o autor formulava quando a temática e o peso econômico dos serviços já era relevante economicamente com tendência crescente, mas sem diagnóstico teórico correspondente. A tese de Arouca é defendida em 1976, enquanto a obra de Mandel que aborda a supercapitalização nos serviços é de 1971 sendo lançada no Brasil somente em 1985 (Mandel, 1985). 
O cuidado médico desenvolver-se-á sob duas dimensões na obra de Arouca: 1- O cuidado como trabalho produtivo na economia capitalista, nesse âmbito a formação social está submetida à sobre determinação do econômico 2- $\mathrm{O}$ cuidado inserido nas relações do sujeito e a sociedade, sintetizada no termo modos de "andar a vida" (Canguilhem, 2009).

Na primeira dimensão, Arouca expõe como os serviços de saúde cumprem o papel de reconstituição das condições necessárias para a reprodução da força de trabalho e desempenha efeito atenuante das tensões sociais próprias da desigualdade social na sociedade capitalista. $\mathrm{O}$ autor expõe articulação da medicina com a formação social capitalista, sendo uma relação diferenciada entre as classes sociais, reconstituição da força de trabalho para a criação do valor ou artigo de consumo para as classes proprietárias, o cuidado tem relação social distinta para as classes sociais.

A perspectiva do autor pode ser sintetizada no trecho abaixo, Arouca diz:

(...) Consideraremos que uma formação social representa uma totalidade histórica concreta onde se compões um conjunto de modos de produção em que um é predominante sobre os demais; isto significa que este modo de produção dominante marca (ou determina), em última instância, o conjunto desta formação.

Uma formação social dada é especificada por uma articulação particular entre seus vários níveis e instâncias, bem como pela sobre-determinação que um destes níveis exerce os demais. Assim, em uma formação social determinada pelo modo de produção capitalista, o econômico determina, em última instância, os demais níveis desta formação. Portanto, o conceito de articulação envolve a idéia de um tipo particular de relação entre diversos níveis, cuja matriz é sobre-determinada por um desses níveis, o qual, neste modo de produção, é dominante.

Quando nos situamos a este nível de análise, não estamos nos referindo à relação médico-paciente como uma troca que envolve valores, nem às relações de autoridade, de representação e de ordem técnica, mas sim à relação estabelecida, dentro de uma formação social, da Medicina com o Econômico, o Político e o Ideológico. Trata-se, portanto, de relacionar a Medicina com a produção em geral, como o poder e com o mundo das representações que cimenta este modo de produção (AROUCA, 2003, p.223-224)

Não obstante as críticas pertinentes a esse trecho da obra, para Arouca, a dimensão do econômico é complementada por outros âmbitos da vida social formuladas por autores de matizes teóricos distintos do marxismo althusseriano adotado, logo, explicitamos que a formulação do autor não pode ser reduzida como meramente economicista.

Na segunda dimensão, o autor constrói um repertório a partir da formulação dos autores, tais como: a crítica à normatização positivista de Canguilhem na definição do 
patológico (2009); a análise discursiva; a biohistória, e consequentemente, o processo de medicalização de Foucault (2002 e 2007) assim como, a crítica da ideia do castigo social inserido na medicalização contemporânea de Illich (1975).

A nosso ver, a mediação de Arouca sobre as duas dimensões se fundamenta no caráter da sociedade capitalista, estritatmente, da contradição gerada pelas condições de solução e de não solução em saúde para os indivíduos, na qual não se realiza do valor de uso do cuidado para suprir as necessidades humanas de saúde. As condições sociais e históricas do processo saúde e doença, contraditoriamente, apresentam condições para satisfação das necessidades, mas as relações capitalistas são elementos impeditivos cruciais para o suprimento das necessidades. Nos termos de Arouca, quando "o desenvolvimento tecnológico e científico de alguns setores, e no caso concreto da medicina, tem tido um baixo impacto na solução de problemas emergentes, bem como de satisfação de novas necessidades" (Ibid, p. 235).

Contudo, as dimensões apresentam conflito de perspectiva teóricas distintas em que pese, a mediação para o entendimento do cuidado médico, mais amplamente, da relação da medicina e sociedade como objeto. Na exposição do autor, em determinadas passagens uma dimensão tem sobreposição em relação à outra. Provavelmente, a construção dissonante está relacionada à teorização a partir de autores com constructos diferentes. Contudo, vários aspectos apresentados no Dilema Preventivista são desenvolvidos posteriormente, por exemplo, o aprofundamento da incorporação de Canguilhem em artigo com Anamaria Tambellini ${ }^{7}$, conforme exposição dos autores:

\footnotetext{
"Portanto, devemos, a partir de Canguilhem:

- Libertar a vida para que ela, através da experiência dos sujeitos concretos, pergunte à ciência sobre a experiência...

- Libertar o homem em sua "experiência", o que significa fornecer-lhe os meios para compreender e controlar o seu "modo de andar a vida..." (A.T. Arouca e S. Arouca, 1976)
}

\footnotetext{
${ }^{7}$ Desenvolvimento realizado pelo Prof. Dr. José Ricardo Ayres na exposição da quinta aula da disciplina Saúde Coletiva: Origens E Deesenvolvimento Em Abordagem Sócio-Histórica lecionada na pós-graduação na Faculdade de Medicina da Universidade de São Paulo em conjunto com os professores Lilia Blima Schraiber e André Motta no segundo semestre de 2017. Discussão presente no artigo (Ayres, 2016)
} 
Desse modo, é a partir de Arouca que essas duas dimensões tornam-se fundamentais para o entendimento da prática social saúde, ou seja, o cuidado médico aborda os aspectos vitais condicionados pelo social histórico tendo a centralidade da sociedade capitalista produtora de mercadoria, por exemplo, na definição de patológico e social a partir do humano, esses valores sociais atribuem a que a medicina deve atender. O conhecimento médico vincula-se à relação com os valores uma dada formação social.

Arouca ressalta que o preventivismo, mesmo sendo uma reorganização dos conhecimentos anteriores, inaugura uma nova relação do trabalho medico, em outras palavras, existe mudança de uma lógica do cuidado individualizado da clínica entre o médico e o paciente no sentido de cuidado em todos os momentos da vida do sujeito. A ampliação do escopo do cuidado, transcende o indivíduo, abarcando a família e a comunidade, percebe se a influência de Foucault (1977) na discussão da clínica como campo nosológico estruturado e do "mago preventivista" e a ampliação do preventivismo para todos os sujeitos (Illich, 1973). As influências críticas da medicalização contemporânea auxiliam a interpretação de Arouca em relação do objeto trabalho médico, visto as implicações no cotidiano do ofício médico na relação social contemporânea. Desse modo, a ampliação da medicalização mescla-se com as determinações da estrutura capitalista, portanto a estratificação social e a divisão social do trabalho na qual o médico ocupa lugar privilegiado na relação com o sujeito que necessita do cuidado. Assim como, a intervenção na vida dos sujeitos constitui-se uma relação mais ampla articulada com a sociabilidade capitalista.

\subsubsection{Capitalismo Monopolista e Trabalho Médico}

A fim de precisar a relação medicina e sociedade, Arouca analisa historicamente a relação entre saúde e doença nas sociedades com modos de produção anteriores, sociedade grega e modo feudal. O autor, a semelhança de Donnangelo, assinala que a medicina durante a primeira metade do século XX manteve seu caráter liberal, com o desenvolvimento do capitalismo monopolista e multinacional. A medicina tornou-se ela em si a organizadora da produção, distribuição e consumo dos cuidados médicos (Ibid, 2003, p.230). Em vista disso, ocorre a ampliação do capital sobre os serviços em sua fase monopolista, logo esse estágio avançado aponta para universalização das mercadorias manifesta nas atividades como o lazer, o sexo e a própria saúde na segunda metade do século XX. A atuação das empresas de serviços de saúde privado vinculados aos seguros 
de saúde os Estados Unidos no período de 1970 é o exemplo destacado, Arouca destaca a propagação da racionalidade capitalista análoga da indústria para os demais setores ${ }^{8}$, Nas palavras de Arouca:

Portanto, tendencialmente, o sistema se configura em crise do ponto de vista capitalista. $\mathrm{O}$ submetimento do cuidado médico à categoria de mercadorias exige o controle e a racionalização do trabalho envolvido nesta produção específica, ou seja, existe a necessidade de transformar este trabalhador independente em trabalhador em geral, que produza ou transfira mais-valia.

A medicina privada (ou liberal) transformou o cuidado médico em mercadoria, mas não transformou a sua prática em atividade capitalista, já que os lucros, obtidos e divididos entre uma população dispersa de profissionais, não permitiram a transformação do dinheiro em capital, sendo gasto na maior parte das vezes, em um consumo de luxo. Assim, neste setor constitui uma fração de classe de alto consumo, mas de baixa densidade, de realização de capital, e o volume de dinheiro circulante no setor prevê um espaço de ampliação altamente viável para a expansão das atividades capitalistas.(Ibid, p.234)

Não obstante, a expansão da racionalidade industrial oriunda do capitalismo monopolista, no caso dos serviços de saúde, os "produtores de cuidado" não estariam submetidos ao controle do trabalho pelas características próprias do trabalho médico ${ }^{9}$,

\begin{abstract}
${ }^{8}$ Mandel (1985) caracteriza o período como de industrialização generalizada, na medida em que características antes industriais do trabalho expandem-se para todos os demais setores. Segundo o autor, tem-se que:

Longe de representar uma —-sociedade pós-industrial, o capitalismo tardio constitui uma industrialização generalizada universal pela primeira vez na história. A mecanização, a padronização, a super-especialização e a fragmentação do trabalho, que no passado determinaram apenas o reino da produção de mercadorias na indústria propriamente dita, penetram agora todos os setores da vida social. Uma das características do capitalismo tardio é que a agricultura está se tornando gradualmente tão industrializada quanto à própria indústria, a esfera da circulação tanto quanto a esfera da produção, o lazer tanto quanto a organização do trabalho. A industrialização da esfera de reprodução constitui o ápice desse processo (...). A "lucratividade" das universidades, academias de música e museus começa a ser calculada da mesma forma que a das fábricas de tijolos ou de parafusos (MANDEL, 1985., p.271-272)
\end{abstract}

Nessa passagem, Mandel considera como ápice do processo de -industrialização a transposição da dinâmica de trabalho capitalista nos serviços de reprodução social. Ressalvamos o termo industrialização, de fato no seu sentido estrito não caberia aos serviços de atividades preponderantemente relacionais, pois não ocorre a mecanização nessas atividades análoga ao sistema produtivo fabril e a subsunção real do trabalhador, porém, o termo industrialização no sentido amplo de açambarcamento de relações sociais capitalistas de trabalho e de consumo dos serviços-mercadorias faz sentido.

9 "Porém, na medida em que os produtores de cuidados funcionam isolados, o controle deste trabalho tornase difícil e a viabilidade da empresa depende da obtenção de fundos cada vez maiores dos consumidores, que compensem "a irracionalidade" do sistema." (...)

"Tal processo que, no interior das indústrias, obedece a uma organização e controle centrais, em alguns setores permanece difuso e descontrolado, como acontece nas chamadas profissões liberais. O capitalismo moderno, na expansão de sua racionalidade, encontra-se com esta barreira, que também foi um produto da industrialização e da ideologia liberal-burguesa" (Ibid, p.234) 
logo tal situação seria uma barreira de racionalização do capitalismo e alguns setores permanecem difusos, por exemplo, profissões liberais. Contudo, amparando-se em Basso (1973), Arouca cita que o domínio do capital não está primordialmente na esfera do trabalho, mas "em todos os domínios da vida política e social” (Ibid, p.235).

De modo preliminar, consideramos o aspecto inaugural da contribuição do autor na realidade brasileira que articulou várias temáticas em o Dilema Preventivista, embora tenha estabelecido relações teórica de ordem eclética, vários desenvolvimentos constituiram teses centrais para o campo da saúde coletiva no âmbito teórico e prático.

\subsection{Medicina como Prática Social sob o Capitalismo e o Mercado de Trabalho Médico no Brasil: A Herança de Cecília Donnangelo à Saúde Coletiva.}

Em Saúde e Sociedade (1976), o objeto central de Donnangelo é a medicina comunitária, todavia, ao aprofundar a análise sobre essa linha específica, desvela princípios da medicina enquanto prática histórico-social e apresenta fundamentos da teoria social em saúde. De acordo com Pereira, tal estudo inaugura a construção do objeto de pesquisa próprio da sociologia da saúde ou, em outros termos, da análise da relação entre saúde e capitalismo (Donnangelo e Pereira, 1976, p.97), enquanto a obra anterior Medicina e Sociedade (1975) representa a análise concreta da inserção do médico no mercado de trabalho. A medicalização da sociedade na modernidade capitalista e sua racionalização inerente são pressupostos da reorganização das práticas como o exemplo a medicina comunitária e das demais. A autora observa que a primeira vista a medicina é caracterizada como mera prática técnica com sustentação cientifico-tecnológica. Contudo, ao identificar os objetos alvos de transformação da medicina: o corpo e o meio físico, observa que esses elementos transcendem a técnica por serem socialmente determinados. Dessa maneira, Donnangelo afirma que a prática médica tem objetos fora dela, na estrutura econômica e política das sociedades ${ }^{10}$ (DONNANGELO, 1976).

\footnotetext{
${ }^{10}$ Donnangelo adverte que a partir da impossibilidade de recobrir todo o campo da prática em Saúde e Sociedade, do saber médico ao produto do trabalho e as formas de organização correspondentes, o foco da análise poderá ser visto como externalidade da própria prática, pois dedica-se as possibilidades de consumo de serviços médicos na sociedade capitalista, diagnostica a tendência de expansão da produção
} 
Nesse sentido, a medicina no contato com seus objetos conforma-se uma prática social vinculada às demais num contexto histórico. Logo, a visão "cientificista" e tecnicista da prática médica supostamente neutra é conformada ideologicamente e fundamentada na estrutura social. De acordo com Canguillem,

\begin{abstract}
"Não se ditam cientificamente normas à vida" e “(...) existe uma medicina porque há homens que se sentem enfermos e não que os homens se enteirem de suas enfermidades porque há médicos e através deles. (...).A própria vida (....) é quem introduz na consciência humana as categorias de saúde e de enfermidade. Essas categorias são biologicamente técnicas e subjetivas e não biologicamente cientificas e objetivas“. Portanto (...) existe uma medicina porque há homens que se sentem enfermos e não que os homens se enteirem de suas enfermidades porque há médicos e através deles. (Canguillem, 2009 , p. 89-92)
\end{abstract}

O contraponto de Canguillem, utilizado por Donnangelo, contrasta com a visão do predomínio biomédico de fundo positivista que afirma sua suposta missão no respaldo da técnica, na qual a linearidade apontaria o cumprimento de caráter progressivo da medicina conforme o avanço técnico da medicina. Conforme caracterização de Conti (1972, p.289) sobre a história tradicional da medicina "a historicidade dos meios e anistoricidade dos objetivos" que significaria supostamente "uma aprendizagem progressiva por parte da humanidade dos meios mais idôneos para curar a enfermidades".

Donnangelo destaca a centralidade histórica da medicalização, especialmente, o papel histórico cumprido pela clínica ${ }^{11}$ (Foucault, 2002): atuação sobre objeto particular não sendo redutível ao cientifico; inseparável da terapêutica; técnica de instauração ou reparação do normal vinculada à satisfação subjetiva de uma norma a ser instaurada. A conformação moderna da clínica precede à ciência biológica, a prática médica não se confunde com a prática científica. "A clínica não é uma ciência e nunca será uma ciência" (Canguillem, 2009 p.90)

Donnangelo para definir o objetivo" básico" da prática social médica, retoma a posição de Boltansky (1979) do corpo como realidade social e que a medicalização cumpre papel disciplinar e normatizadora do corpo para a atividade produtiva. A prática médica objetiva o corpo dos sujeitos antes de tudo como agente de trabalho, seu central. (DONNANGELO, 1976, p.30)

11 "Para que a clínica fosse possível como forma de conhecimento foi necessária toda uma reorganização do campo hospitalar, uma nova definição do estatuto do enfermo na sociedade e a instauração de uma certa relação entre a assistência e a experiência, o auxílio e o saber” (Foucault, 2002,p.226) 
correspondente significado na estrutura de produção, coletivamente, a quantidade de corpos socialmente necessários. Esse corpo socialmente investido não é homogêneo, os diversos corpos não têm significalidade igual, mas ao contrário se dimensionam e adquirem significados particulares nas representações pela qual estão na estrutura de produção social. A autora observa que tal dinâmica não encerra a historicidade da atuação da medicina sobre o corpo social, embora seja indispensável para estudos das formas da prática médica ${ }^{12}$.

A atenção sobre a historicidade da prática médica na formação social capitalista tem dois eixos específicos, a restituição da força de trabalho para a reprodução do capital e na provisão estatal da atenção médica com objetivo de atenuação nos antagonismos sociais. Em seu desenvolvimento, tanto a reprodução da força de trabalho coletiva quanto as necessidades de atenção médica e de consumo dos trabalhadores correspondem às necessidades da acumulação do capital. Essa interpretação da prática médica na estrutura social capitalista subverte qualquer análise neutra das relações de trabalho do médico e, logicamente, dos demais profissionais de saúde. Embora não tenha como foco o trabalho das ocupações em saúde, ao analisar a articulação entre medicina e sociedade, criticamente ao projeto da medicina comunitária, a autora esboça as principais tendências contemporâneas na quais o trabalho em saúde está envolto. Assim como, identifica na historiografia que o trabalhador médico tem estatuto diferente da maioria das outras ocupações capitalistas na modernidade.

Donnnangelo desenvolve como essa mudança social ampla conforma o trabalho do médico. A autora diz:

\footnotetext{
“ De outra parte, a imediatez na relação entre o trabalhador e os instrumentos de trabalho, consubstanciada na clínica, proporciona as bases para uma organização de todos os elementos do processo de produção de serviços sob a forma da medicina liberal ou artesanal: uma ideologia do trabalho - o liberalismo médico- uma relação especifica de troca desse trabalho por renda em um mercado livre uma delimitação particular do volume e modalidades do consumo. Finalmente, o desenvolvimento dos meios de trabalho médico e com
}

\footnotetext{
12 (...) a compreensão do modo pelo qual a sociedade toma seus corpos, os quantifica e lhes atribui significado cultural, política e econômica é indispensável para explicar as formas assumidas pela prática médica, sem que com isso se pretendesse também afirmar que todos os elementos que constituem o campo da medicina são estruturados fora dela. Encontra-se ainda por fazer uma história da medicina capaz de dar conta, sistematicamente, das determinações econômicas e políticas do corpo e de sua relação com as formas históricas da produção médica (...) (Donnangelo, 1976, p. 27)
} 
eles, o da prática médica, responde a outras ordens não redutíveis ao científico" (Donnangelo, 1976, p.18)"

A caracterização clássica do trabalho médico instaurado pela clínica na Europa, onde os meios de trabalho já se instaura com um conjunto princípios biológicos e equipamentos técnicos, porém, a clínica será o meio de trabalho que transformará o trabalho do médico, que terá estatuto próprio com relativa independência dos princípios da técnica e das ciências servirá como paralelo para Donnangelo realizar a análise da integração do profissional médico na realidade brasileira Em Medicina a Sociedade (1975). Tais considerações servirão para o estudo de formas posteriores de ampliação e superação da própria clinica como meio de trabalho devido ao desenvolvimento da lógica do capital.

\title{
1.2.1 O Assalariamento do Profissional Médico no Mercado de Trabalho no Brasil
}

Em Medicina e Sociedade: o médico e seu mercado de trabalho (1975), Donnangelo combina vasta pesquisa de campo da realidade dos profissionais médicos com elaboração de relevância teórica que marcou as décadas subsequentes. A autora caracteriza tipicamente a medicina liberal como a produtora dos serviços com a propriedade dos meios de trabalho pelo profissional que atende uma clientela livre no mercado. A autora demonstra a tendência de destituição do exercício desse tipo de medicina devido às formas de transição da política estatal de saúde, a organização da produção dos serviços de saúde e do mercado, nos termos da autora:

\begin{abstract}
A medicina liberal, vale dizer, o padrão de produção autônoma dos serviços supõe a presença de uma clientela livre no mercado e implica o controle do processo de trabalho, assim como a propriedade dos meios de trabalho, pelo produtor direto dos serviços. Ao nível das concepções relativas à medicina e ao trabalho médico, desenvolve-se um ética correspondentemente liberal, em cujo núcleo o ideal de autonomia do produtor reveste o sentido de exigência técnica inerente à medicina como ciência e prática. As inovações na técnica de produção, diversificação e a ampliação dos meios de trabalho, fornecem as bases para o solapamento progressivo dessa forma de organização, ao reduzirem as possibilidades de controle, pelo produtor direto, da totalidade do processo de trabalho, proporcionando as bases para sua apropriação em moldes distintos dos que caracterizam medicina liberal. (Donnangelo, 1975, p.171)
\end{abstract}

Embora mencione a diminuição do controle do processo de trabalho, a autora realiza de forma genérica, pois esse não é seu objeto de estudo estrito, logo se trata de uma consideração da tendência histórica que cabe à medicina assim como as demais profissionais historicamente liberais com a perda de autonomia do mercado (Ibid, p.10). A partir dessa constatação, a autora confirma o diagnóstico da tendência de perda de autonomia do trabalho médico no contexto da década de 1970. Na pesquisa, expõe a 
heterogeneidade da inserção dos médicos no mercado de trabalho pela oscilação entre os polos de assalariamento e a autonomia por exercício liberal ou empresarial. Traçamos um paralelo da tese apresentada por Donnangelo com a obra Trabalho e Capital Monopolista de Braverman (1987), em que pese abordagens e amplitudes distintas, existe convergência parcial na elaboração dos autores, pois tratam de fenômeno social semelhante em período análogo. A autora expõe a perda de autonomia no mercado da profissão liberal médica na década de 1970 no Brasil, enquanto Braverman aponta a transformação histórica do trabalho dos funcionários de escritórios e profissionais liberais prestadores de serviços compreendida no período do século XIX e a década de 1970 nos Estados Unidos. O autor expõe a proletarização dos antigos profissionais liberais devido ao desenvolvimento do capitalismo monopolista, diagnostica a incorporação dos preceitos tayloristas e à tendência da desqualificação no processo de trabalho. Donnangelo não analisa o trabalho médico em stricto sensu, todavia, a autora demonstra em termos gerais a mudança do caráter liberal para o assalariamento na chave maior ou menor autonomia do profissional/trabalhador ${ }^{13}$.

Donnangelo também discute a dimensão ideológica dos profissionais oriunda dessa heterogeneidade de inserção no mercado de trabalho e desmistifica a ideia de que os médicos se enquadrariam majoritariamente na "ideologia liberal" (Ibid, p.159). Na análise, a autora vincula esse afastamento do projeto liberal justamente pela impossibilidade de efetivação da postura tradicional no mercado contemporâneo, logo, o projeto liberal está distante da maioria dos médicos acarretando consequências sobre a autonomia e as condições de trabalho. De acordo com Donnangelo, a transição do padrão liberal para o assalariamento se manifesta de forma plural nas expectativas e avaliações dos profissionais, essa tendência de diferenciação das expectativas, é sintetizada como "resultante das pressões mais imediatas do mercado sobre o médico" (Ibid, p.163).

Donnangelo sintetiza dois padrões gerais de atitude e entendimento referente à ideologia ocupacional dos médicos a partir das respostas dos entrevistados. O primeiro grupo refere-se aos profissionais assalariados, enquanto o segundo grupo se enquadra no padrão liberal de trabalho. Para o primeiro segmento, as prioridades são expressas em

\footnotetext{
${ }^{13}$ Essa discussão sobre o controle e autonomia no processo de trabalho do médico e das demais profissões em saúde estará no centro e dividirá perspectivas de toda bibliografia da saúde coletiva e da sociologia do trabalho na abordagem do setor.
} 
temas tais como: a melhoria da remuneração e das condições técnicas de trabalho, assim como, melhor relação entre as relações entre empregado e empregador. As entrevistas presentes nesse grupo indicam temas atuais como o estabelecimento de padrão de mais um emprego para o médico e vínculos empregatícios irregulares ${ }^{14}$. No segundo segmento, o padrão das respostas tem como pressuposto a afirmação do trabalho autônomo, a medicina como profissão e a negação do assalariamento ${ }^{15}$. A autora identifica outros padrões de resposta, o terceiro tipo refere-se à perspectiva de maior investimento do Estado no segmento privado onde predomina a ideologia empresarial e tem perspectiva pragmática de privatização ${ }^{16}$ (Ibid, p.163-165).

Donnangelo observa que as atitudes e os entendimentos dos médicos acerca de sua situação são descritos com imprecisões conceituais, por exemplo, na percepção dos profissionais sobre os termos "profissional" e "empresário", pois independente da classificação descrita, ambos atuam na dimensão do trabalho assistencial e o empresário médico se distingue do empresário capitalista típico. De acordo com Donnangelo:

Essa indistinção, estabelecida ao nível da prática profissional, contribui para atenuar a percepção da heterogeneidade da categoria ocupacional, tanto pelos seus membros como pelo observador que não disponhas de instrumentos adequados de análise. Considerado o conjunto das atividades desenvolvidas pelo empresário, observa-se que o seu trabalho se concentra, em termos quantitativos, na prestação direta de serviços no interior da empresa. (Ibid, p.119)

Para além das respostas aparentes e típicas na dimensão da ideologia ocupacional, a questão objetiva acerca do entendimento do profissional médico sobre sua condição e acerca da estratificação interna da categoria desenvolver a partir dos seguintes aspectos:

14 Entrevistas enquadradas no primeiro segmento "O principal problema é o do salário". Ele é desproporcional e o médico precisa ter muitos empregos. Se fosse bem pago poderia ficar em um só e aumentar seu padrão de eficiência" e "O maior problema do médico é que ele é empregado irregularmente, sem contrato. Pode ser despedido, sem problemas. Seria preciso regularizar a situação do médico diante das empresas particulares. Ele deveria ser contratado e não trabalhar como autônomo dentro das empresas" (Ibid, p.164)

${ }^{15}$ Entrevista enquadrada no segundo segmento "É preciso fazer voltar a ética profissional, evitando que médicos aceitem empregos ridículos. Compreendo que muitos colegas tenham iniciado na carreira pública por pessimismo, falta de confiança em si, dificuldades econômicas no inicio. Mas, na hora que puderem deveriam e devem sair, para usufruir a beleza a profissão médica. Não há medicina livre escolha (...)"(Ibid, p.164)

${ }^{16}$ Entrevistas enquadradas no terceiro segmento "O que interessa é que a assistência seja feita não através de órgãos públicos, mas através de convênios com empresas particulares. O governo é péssimo administrador. Seria preciso acabar com em que o Governo é o patrão"; “ A medicina privada é mais barata e eficiente que a do Estado (...) (Ibid, p.165) 
“ (...) o maior ou menor controle sobre os meios de produção e estratificação interna à categoria ocupacional, em termos de área de atividade profissional e montante de renda." (Ibid, p.120). A autora identifica correspondência entre os níveis de renda auferidos e o controle sobre os meios de produção, indicando que quanto maior detalhamento da inserção no mercado é possível realizar um escalonamento por faixa de renda (Ibid. p.122). Donnangelo conclui que a ênfase nas características da profissão e a valorização da autonomia estão correlacionadas com o grau de atividade autônoma do médico ${ }^{17}$ (Ibid, p.167).

Em nossa visão, as proposições de Donnangelo são centrais porque têm o propósito de apreender a dinâmica da sociedade brasileira ${ }^{18}$ tanto sobre o estudo do trabalho médico quanto do temário desenvolvido em Saúde e Sociedade (1976), sendo assim, a autora correlacionou o trabalho médico com duas categorias fundamentais: Estado e capital no Brasil vinculado aos serviços de saúde. A análise da inserção do profissional médico no mercado de trabalho na fase urbano-industrial na década de 1970 na Região Metropolitana de São Paulo transcende às questões metodológicas de recorte da pesquisa empírica, na década de 1970, grande parte da população era composta por trabalhadores rurais e informais urbanos que não tinham acesso aos serviços de saúde (Ianni et all, 2016; Vita, 2012 ). Logo, as relações sociais e a luta por direitos da população urbana e trabalhadora da indústria têm dinâmica distinta das relações características do campo no país.

A caracterização sobre a fase urbano industrial no capitalismo brasileiro se insere na temática mais ampla desenvolvida por Pereira (1970) acerca do subdesenvolvimento brasileiro. Para o autor ocorreu a "urbanizanização sociopática" na América Latina e

\footnotetext{
17 "Mas dos dados permitem uma outra constatação, qual seja, a de que a definição de interesses tende a obedecer um padrão que se encontra relacionado às modalidades particulares de integração no mercado. Este aspecto da diferenciação entre os produtores revela-se, particularmente, pela comparação do modo que se distribuem os dois primeiros tipos de resposta: a partir da categoria dos assalariados - que concentram as suas "definições de interesses" em aspectos relacionados à melhoria das condições particulares em que se processa o seu trabalho - a ênfase nas características da profissão e na valorização da autonomia tende a se acentuar, progressivamente, na medida em que amplia a área de atividade autônoma do médico"(Ibid, p.167)

${ }^{18}$ Característica presente nos autores fundacionais do campo da saúde coletiva ou sob nossa denominação de teoria marxista clássica sobre o trabalho em saúde. O mesmo se aplica a contribuição de Arouca (2003) como abordaremos na próxima seção do texto.
} 
essas realidades estariam propensas às tensões sociais e a instabilidade política. Pereira observa sobre o possível papel do Estado como agente do desenvolvimento político econômico para enfrentar tais impasses. Donnangelo se ancora nesse debate para a compreensão da atuação do Estado na provisão de serviços de saúde para atenuar às tensões sociais e por ser um agente político-econômico privilegiado, logo a política estatal de saúde analisada por Donnangelo tem a noção implícita do subdesenvolvimento.

Embora a autora estude as características do médico no mercado de trabalho, as correspondentes ideologias ocupacionais e a dimensão técnica do trabalho no processo de produção dos serviços de saúde de modo aprofundado, destaca o espaço-tempo social específico que a dinâmica da sociedade de classes pressionaram a provisão de serviços públicos por parte do Estado, consequentemente, a atuação do Estado é importante elemento para a constituição do mercado de trabalho do profissional médico e suas modificações. No contexto brasileiro da década de 1970, a autora observa o emprego dos profissionais médicos às empresas privadas e ao serviço público, Donnangelo relaciona como o Estado nacional estava submetido às pressões das classes sociais na definição da provisão de serviços tendo como resultante a expansão da assistência médica aos setores populares tanto por meio dos serviços públicos quanto pelo segmento privado. Donnangelo discute questões de grande magnitude, a autora aponta como a dinâmica política das classes sociais na sociedade brasileira age sobre o Estado nacional, por um lado, e a organização da produção e consumo dos serviços de saúde, por outro, a conformação do mercado consumidor, em seus termos "clientela".

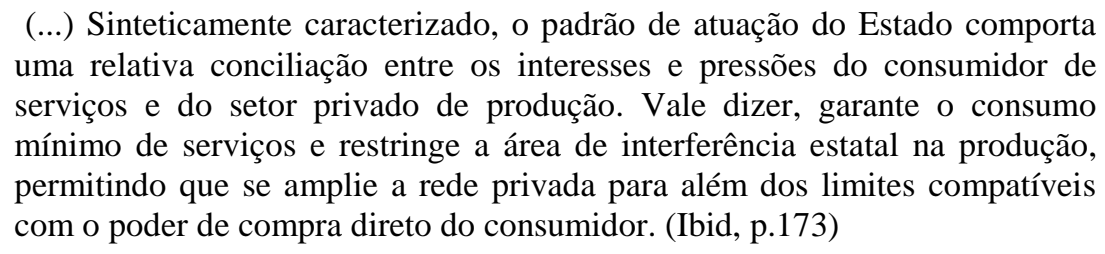

$\mathrm{Na}$ visão da autora, existe a resposta do Estado em relação ao consumo de parte da população, contudo, como determinação geral, a ação estatal objetiva a atenuação das tensões sociais e a recomposição da força de trabalho. Sobre a atuação estatal no que tange aos serviços públicos e privados de saúde, o Estado no Brasil cumpriu papel fomentador dos serviços privados em saúde. Nas palavras de Donnangelo:

Retomando, em linhas gerais, o processo que se considerou como de privilegiamento ou preservação do produtor privado, é possível sintetizá-lo: consiste na afirmação de um padrão geral e constante de compras de serviços pelo Estado, com o que, embora introduzindo no mercado mecanismos de 
controle de preços, ele evita assumir papel significativo como produtor; comporta formas de redefinição da política estatal tendencialmente favoráveis à preservação do setor privado, expressas por variações no padrão de compra de serviços que se estende, desde a compra direta, as novas formas de autonomia do produtor privado na manipulação de meios de produção originalmente sob controle do Estado (Ibid, p.44)

A caracterização feita por Donnangelo há cerca de 40 anos auxilia-nos na compreensão de como o Estado está sujeito às relações e choques de interesse de classes. O Estado brasileiro proveu serviços motivados pela pressão dos assalariados urbanos, simultaneamente, incentivou a presença dos serviços privados atendendo aos interesses desses grupos econômicos e suas classes sociais, possibilitando maior autonomia desses e menor controle por parte do Estado (Donnangelo, 1975). Esse aspecto é vigente e se desenvolve na incipiência da relação de serviços públicos e na própria constituição das “empresas médicas” ou serviços privados no país. Refletimos a partir da autora, que o Estado não caminha para a estatização total dos serviços e os serviços públicos em sua gênese já contam com o mercado privado de saúde de forma "suplementar", seja o Estado comprando serviços desse segmento, ausentando-se para abrir espaços de mercado ou claramente incentivando com benefícios o setor.

Em paralelo a atuação estatal, a autora observa o desenvolvimento do "setor de produção dos serviços de saúde", observando como o complexo médico industrial se expande e aprofunda a divisão técnica do trabalho no segmento pelo aumento da especialização e do desenvolvimento científico, consequentemente, a resultante do aumento dos custos da provisão de serviços, em grande parte, devido à incorporação tecnológica acarreta o solapamento do trabalho médico liberal na sua forma tradicional tendo como expressão a forma dominante do assalariamento. No caso brasileiro, a clientela dos serviços de saúde, o aspecto complementar dessa forma capitalista contemporânea, em outros termos, o mercado consumidor é fomentado pelo Estado que possibilita maior acesso aos serviços de saúde por provisão própria, mas permite/incentiva o segmento privado a não prover todos os serviços necessários ${ }^{19}$.

\footnotetext{
19 “ Concluindo, o tipo de exploração dos elementos obtidos através do estudo direto da força de trabalho, visou predominante referi-lo a duas ordens de alterações que se processam no mercado: a interferência do Estado, relacionada ao desenvolvimento da sociedade urbano-industrial-capitalista, e acarretando um padrão peculiar de controle dos meios de produção; a mudança científico-tecnológica, com a consequente ampliação e concentração dos meios de trabalho.
}

Da perspectiva do produtor direto, elas correspondem ao duplo processo de separação entre ele e seus instrumentos de trabalho e do assalariamento como uma modalidade nova e dominante de integração no 
Donnangelo analisa a relação social e histórica estabelecida pelo setor de produção dos serviços em saúde no capitalismo brasileiro, a relação entre profissional médico e o seu objeto de trabalho está inserida em uma relação histórica na qual, o desenvolvimento científico tecnológico (especialização em diagnósticos e terapêuticas), investimento de recursos de grande monta transcendem ao exercício individual do profissional muito além do assalariamento conformando a própria prática médica na reprodução da força de trabalho e no controle das tensões sociais (Donnangelo e Pereira, 1976, p.14). Por tal motivo, a relação social envolvida na dimensão técnica do trabalho médico será melhor desenvolvida em Saúde e Sociedade. Nessa obra, pelo seu nível de abstração, os pressupostos da relação entre saúde e formação social capitalista no Brasil são desenhados para diversos temas, para além do trabalho dos profissionais de saúde, embora o termo prática em Donnangelo seja vinculado ao conceito de trabalho ${ }^{20}$, sugerimos que Donnangelo se refere ao termo prática ao se referir aos aspectos sociais e históricos mais amplos e o termo trabalho para referir-se ao seu uso mais convencional localizado.

\subsection{O Trabalho em Saúde na Perspectiva Ontológica e na Forma Histórica do Capitalismo na obra de Ricardo Bruno Mendes-Gonçalves}

Esboçamos o percurso teórico de Mendes-Gonçalves referente a conceituação da categoria trabalho como fundamento da prática médica e a construção abstrata do trabalho em saúde. Em Medicina e História: Raízes Sociais do Trabalho Médico (1979), o autor propõe-se a desenvolver os pressupostos de Donnangelo ${ }^{21}(1976)$ ao estudar a prática social pelo ângulo do trabalho. Donnangelo estudou o significado das relações saúde e capitalismo, em termos gerais, desmistificou o caráter da neutralidade da técnica envolvida e analisou a expansão da produção de serviços e generalização do consumo por contingentes amplos da população, e especificamente, a medicina comunitária. A

mercado; equivale a dizer, a uma redefinição de sua posição na estrutura social.” (Donnangelo, 1975, p.123)

${ }^{20}$ A relação entre os termos práticas médicas ou prática em saúde e o conceito de trabalho é aspecto implícito de debate na bibliografia acerca do trabalho nos serviços de saúde e exploraremos ao decorrer da análise.

21 "A articulação da medicina comas demais práticas sociais constitui o ponto estratégico do qual melhor se pode apreender o seu caráter histórico” (Donnangelo, 1976, p. 15.) 
preocupação central ainda está na prática médica a semelhança de Donnangelo (1975, 1976) e Arouca (2003) nas primeiras obras, todavia o aspecto original é a utilização do conceito de trabalho sob influência da sociologia do trabalho (Friedmann, 1968; Braverman,1987) e da filosofia marxiana (Giannoti, 1973).

O pano de fundo é a relação medicina e capitalismo, contudo, a constituição histórica da medicina é prévia ao capitalismo, elemento necessário para o entendimento desse trabalho especifico na contemporaneidade. As diversas referências teóricas, a concepção dialética do trabalho (Giannoti, 1973) combinadas com a rigorosa epistemologia de Canguillem (2009) permitem ao autor diferenciar-se da visão de inspiração estruturalista ou economicista, ao apontar a crítica a essas leituras ${ }^{22}$ observa: "perde-se com isso a possibilidade de apreender um desenvolvimento histórico que não seja mais que o reflexo da história daqueles jogos de interesse [capitalistas]" (MendesGonçalves, 1979, p. 5). Contudo, sua diferenciação do economicismo, não abre mão do caráter crítico de caráter marxista as leituras apologéticas que ignoram a dimensão social, onde a história da medicina serve como componente ideológico, nos termos do autor:

\begin{abstract}
Em um sentido geral, a tentativa (bem-sucedida, já que transformada em concepção predominante; malsucedida, já que não explica nada, ainda que leve a muita satisfação autocomplacente) de isentar a medicina da "contrainte" do trabalho pode ser identificada na base da tradição mais volumosa entre seus intérpretes, aquela corrente de interpretação histórica que reduz o passado à crônica dos lances de "genialidade" que permitiram os avanços da ciência (nessa óptica não falta lugar também para os "retrocessos") em sua luta heroica contra a natureza e apesar da oposição (ou do favorecimento) do ambiente social, até chegar ao glorioso presente em que os problemas ou estão resolvidos em uma generalidade ou esperam o próximo capítulo dessa romanesca história em que a medicina posa sempre de heroína bem comportada. Para caber nesse molde a medicina é retirada de sua condição de trabalho e transformada em ciência, e como ciência é desvinculada de suas relações com o trabalho para ser situada em uma terra-de-ninguém de paisagem quase divina (Ibid, p.16)
\end{abstract}

Inquestionavelmente, a compreensão crítica sobre a prática médica a partir dos elementos constitutivos de trabalho na sociedade capitalista possibilitou a interpretação da historicidade e a crítica ao tecnicismo e à ideologia. O autor parte do estudo do trabalho médico, contudo ao analisar as determinações estruturais do trabalho médico, aborda a prática médica como um todo, logo esse é o objeto da pesquisa sendo o trabalho o ângulo

\footnotetext{
${ }^{22}$ Especificamente, a obra de Navarro, Medicine Under Capitalism (1976)
} 
privilegiado a partir dele desenvolve as características gerais da historicidade da prática (Mendes-Gonçalves, 1979)

1.3.1 A Análise da Organização do Trabalho nos Serviços e a Acepção Ampla de Tecnologia

Em Tecnologia e Organização Social das Práticas de Saúde. Características Tecnológica do Processo de Trabalho na Rede Estadual de Centros de Saúde de São Paulo (1994), a discussão dos modelos de organização de saúde se insere na historiografia da relação entre sociedade, saúde pública e o consumo privado na dinâmica paulista. Os Centros de Saúde se configuraram como uma nova modalidade tecnoassistencial por Paula Souza (Mendes-Gonçalves, 1994). Mendes-Gonçalves fundamenta-se em Rattner (1980) para a acepção ampla de tecnologia. Sinalizamos que tal definição pautará os demais estudos sobre o trabalho em saúde e de modelos assistenciais e implicará em uso do termo tecnologia que não será somente aos autores da intepretação marxista ou da teoria do processo de trabalho em saúde:

\begin{abstract}
"A marca mais característica do pensamento contemporâneo a respeito da tecnologia, em qualquer âmbito do conhecimento, em todo campo de práticas, é a redução do significado do termo ao conjunto de instrumentos materiais do trabalho. Por tecnologia se designa um conjunto de coisas, de objetos materiais, denotando primordialmente sua função técnica nos processos produtivos. Nada de especial haveria nessa restrição, se ela não correspondesse também a um movimento de omissão do aspecto essencial desses instrumentos, agora dito tecnológicos, de só virem ganhar existência no trabalho enquanto expressarem relações provisoriamente adequadas, estabelecidas entre os homens e os objetos sobre quais trabalham, relações cuja adequação não se estabelece por referência à capacidade produtiva ou à eficácia útil dos instrumentos, mas com respeito às relações sociais de produção, organizados conforme as quais os homens então modificam a natureza e a história." (Grifos nossos, Ibid, p.1516)
\end{abstract}

A categoria tecnologia condensava diversos objetivos do autor, conforme seus

termos:

(...) primeiro "objetivo" deste projeto de pesquisa, desdobrado no interesse de estudar tais setores a partir da conceituação de tecnologia (...) enquanto conjunto de saberes e instrumentos que expresse, nos processos de produção de serviços, a rede de relações sociais em que seus agentes articulam sua prática em uma totalidade social" (Ibid, p.32)

(...) tecnologia refere-se aos nexos técnicos estabelecidos no interior do processo de trabalho entre atividades operante e os objetos de trabalho, através daqueles instrumentos. Refere-se às concepções reciprocamente assumidas ou assumíveis pelo conjunto daquele três momentos do processo de trabalho, dados os objetivos, as finalidades do mesmo (Ibid, p.18) 
Nesse sentido, a partir de Rattner (1980), a tecnologia não pode ser restrita aos equipamentos e materiais, assim como, refere-se ao conjunto de técnicas, instrumentos e conhecimentos articulados no processo de trabalho. Em Mendes-Gonçalves, para além da dimensão objetiva, a tecnologia condensará o conjunto das relações sociais históricas em saúde. Em nossa opinião, essa decisão teórica se fundamentou em uma discussão introdutória do termo tecnologia em uma obra cujo o propósito é a discussão do papel da tecnologia no desenvolvimento social. Mendes-Gonçalves explorou a categoria processo de trabalho a partir da interpretação da obra de Marx na qual essa ação humana tem centralidade na produção da vida social, fundamento do materialismo histórico e explicitamente não considerou a abordagem marxiana sobre o termo tecnologia, tal configuração produzirá "conflitos" entre as duas categorias.

Em síntese, a tecnologia como mudança qualitativa da intervenção humana sobre a natureza e a relação social histórica oriunda dessa relação material na história será reduzida na discussão do autor e se referirá ao conjunto do trabalho e da sociabilidade humana. Deve ficar claro que a crítica a amplitude do termo não pretende invalidar as contribuições analíticas com a utilização do termo, mas problematiza-las.

\subsubsection{A Fundamentação Ontológica e Histórica do Trabalho}

Em relação ao conjunto das obras do autor existe diferenciações epistemológicas associadas à referência marxista. $\mathrm{Na}$ análise histórica da medicina, destaca-se a significativa influência de Canguillem no estudo da formação de conceitos ou "história teórica da prática" combinada com a "história social da prática" (Mendes-Gonçalves, 1979) ${ }^{23}$. No trabalho de doutoramento, sobre a organização dos serviços na rede estadual, realiza mediação do instrumental marxista e weberiano. Dessa forma, a categoria totalidade histórica do modo de produção capitalista "dialoga" com a aproximação compreensiva da fonte de informação como "núcleo substantivos de significação", a semelhança da construção intelectual do tipo ideal e a sua utilização na realidade (Mendes-Gonçalves, 1994).

Esse trajeto se encerra na teorização mais desenvolvida realizada sobre o trabalho em saúde em Práticas de saúde: processos de trabalho e necessidades (2017) publicado

\footnotetext{
${ }^{23}$ Aspectos abordados no texto de Nunes (2017).
} 
originalmente em 1992 com o propósito formativo de trabalhadores. É a partir do pressuposto filosófico da ontologia do ser social fundada pelo trabalho que MendesGoncalves teorizará o trabalho e as correspondentes necessidades em saúde. O autor expõe as seguintes categorias abstratas: energia e a centralidade do processo de transformação e não de suposto caráter espontâneo da transformação. Destaca a processualidade distinta entre homem e natureza, pois existem diversos exemplos de dispêndio de energia para transformações físicas não realizadas pela intencionalidade humana.

Tal preambulo define que as transformações não naturais ou causais são do âmbito da intencionalidade humana. Mendes-Gonçalves desenvolve a categoria trabalho como inerentemente humana e presente no intercâmbio humanidade-natureza ${ }^{24}$. Trata-se do momento do por teleológico da ideação no pensamento humano com a objetivação através do trabalho. Desse modo, expõe o momento ontológico no qual o homem confronta e transforma a natureza, nessa relação constitui se propriamente como humano.

A conceituação do processo de trabalho com tal pressuposto filosófico já estava presente na obra de Mendes-Gonçalves, todavia, não desenvolvido, conforme trecho do livro oriundo da tese de doutoramento:

O processo de trabalho não é apenas dispêndio mecânico de forças: é a forma
mais especialmente humana de socialidade, de gênese histórica. Em cada grâo
de tecnologia estão contidos, assim, ao mesmo tempo todas as determinações
do passados que nela desembocam e toda construção viva do futuro (Mendes-
Gonçalves, 1994, p. 268)

No texto de 1992, o autor se aprofunda nos pressupostos teóricos, tornando explicito que ação dotada de teleologia não implica em uma concepção teleológica da história. Distintamente da concepção teleológica, a relação homem e natureza origina a concepção materialista da história e da produção da vida social. Nessa processualidade o homem altera a sua própria condição natural ${ }^{25}$. Nas palavras do autor tem-se que:

\footnotetext{
${ }^{24}$ Indubitavelmente, as principais referências do autor são as obras elaboradas por Marx na década de 1840, Ideologia Alemã (2007) e Manuscritos Econômico-Filosóficos (2011) e a Ontologia do Ser Social de Luckács (2011), particularmente, sua seção sobre o Trabalho.

25 Discussão presente originariamente em Engels e desenvolvida filosoficamente posteriormente por Luckács. "Deste modo, faz de uma coisa da natureza órgão de sua própria atividade, um órgão que acrescenta a seus próprios órgãos corporais aumentando seu próprio corpo natural, apesar da Bíblia”(Marx, 1968b, p. 203 In
} 
"Toda objetualidade da natureza decorre da presença de um sujeito, para o qual ela é objeto, o que enlaça subjetividade e objetividade de modo inseparável; se esse sujeito transformar a si próprio enquanto se reproduz à custa de sua metabolização da natureza, ambos tornar-se-ão históricos."(MendesGonçalves, 2017, p.308)

E expõe graficamente a centralidade do processo de trabalho:

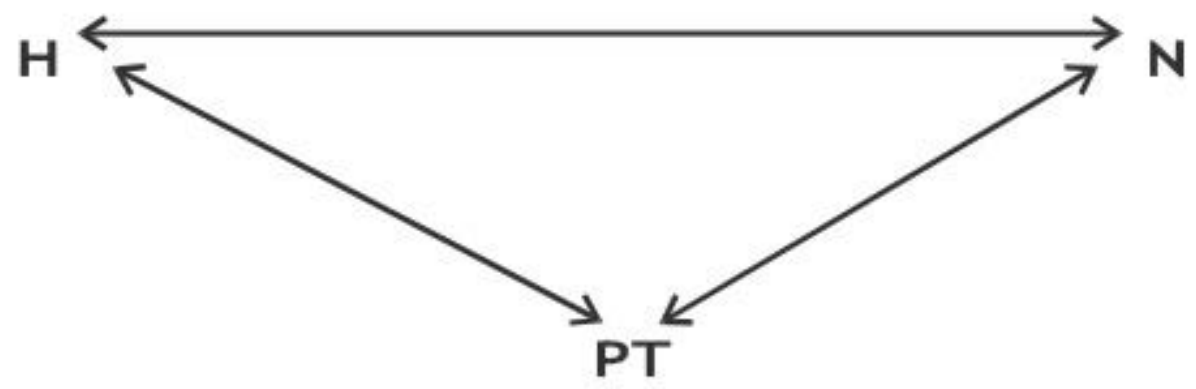

(Mendes-Gonçalves, 2017, p.318)

A passagem e a representação gráfica fundamentam a relação sujeito e objeto; expõe o fundamento do materialismo histórico como fluxo aberto pela ação humana na relação com a natureza na produção da vida social. $O$ autor desenvolve como a intencionalidade projetada pelo humano interfere de acordo com as configurações e legalidades causais inerentes à natureza. A intencionalidade humana objetiva dominar os aspectos naturais e desenvolver técnicas adequadas para sanar um determinado carecimento:

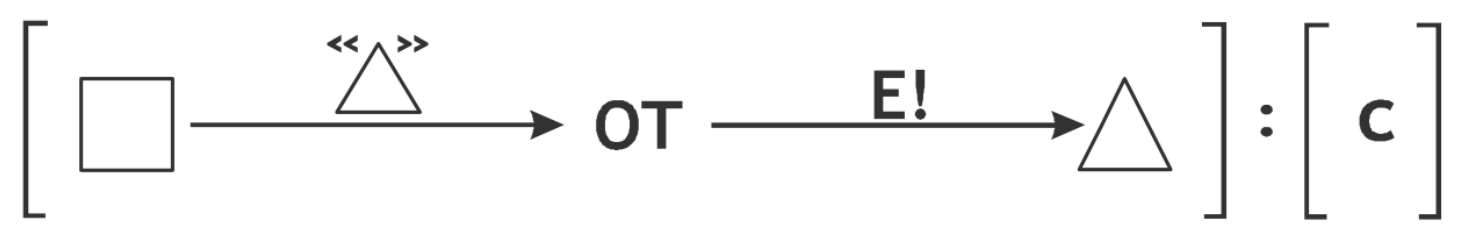

(Mendes-Gonçalves, 2017, p. 307)

A representação gráfica estabelece a correspondência com determinado carecimento condensada no processo de trabalho com a descrição da integralidade dos 
elementos: a prévia ideação; a utilização de objeto; dispêndio de energia com um propósito.

\begin{abstract}
"Esses utensílios, os instrumentos de trabalho (I), o braço, a mão e a clava, correspondem, portanto à forma pela qual a energia se incorpora ao processo de trabalho, e devem apresentar a capacidade de sintetizar, como se disse, as qualidades de e o projeto de $\mathrm{U}$ em uma ação transformadora. Convém examiná-los melhor, entretanto, para ver de onde vem esse seu poder sintetizador, bem como para bem avaliar que características imprimem ao trabalho humano (Ibid, p.309)
\end{abstract}

Embora pareça que o autor esteja "somente retomando" a teoria marxiana sobre o trabalho humano, esse está desenvolvendo elaborações chaves sobre o trabalho em saúde. Conforme o propósito implícito na reflexão filosófica na relação entre teleologia da ação humana e causalidade fisíco-natural ${ }^{26}$, deve se observar que a referida causalidade é mais complexa do que estabelecida na "ciência normal" e consagrada no positivismo. O trabalho em saúde intervém sobre o corpo, necessariamente sua atuação intencional com propósito estabelecido relacionar-se-á com a "legalidade" ou característica do metabolismo orgânico. A relação desenvolvida entre metabolismo orgânico corpóreo e metabolismo social homem e natureza, sintetizam totalidades diferenciadas, porém, componentes da totalidade em outro nível de abstração.

A elaboração do pensamento em saúde do autor baseia-se na categoria trabalho, todavia, na definição de processo de trabalho do autor, é necessário apontamento crítico. Ao nosso ver, a passagem fundamental para a constituição do humano não é idêntica a categoria processo de trabalho na ontologia marxiana do ser social, por mais que essa interpretação não pode ser caracterizada como equivocada ${ }^{27}$. A primeira vista, o processo de trabalho aparece como dedução lógica, pois o por teleológico é anterior e central na

\footnotetext{
26 "O exemplo da queimada é um aprofundamento e reflexão sobre a relação anterior "A queimada é um processo de trabalho que se vale do poder de uma parte da natureza de transformar a outra, não mais em sua ocorrência "natural", mas em sua ocorrência teleologicamente vinculada a um carecimento." (Ibid, 310 )

27 "Pressupomos o trabalho numa forma em que ele diz respeito unicamente ao homem. Uma aranha executa operações semelhantes às do tecelão, e uma abelha envergonha muitos arquitetos com a estrutura de sua colmeia. Porém, o que desde o início distingue o pior arquiteto da melhor abelha é o fato de que o primeiro tem a colmeia em sua mente antes de construí-la com a cera. No final do processo de trabalho, chega-se a um resultado que já estava presente na representação do trabalhador no início do processo, portanto, um resultado que já existia idealmente. Isso não significa que ele se limite a uma alteração da forma do elemento natural; ele realiza neste último, ao mesmo tempo, seu objetivo, que ele sabe que determina, como lei, o tipo e o modo de sua atividade e ao qual ele tem de subordinar sua vontade.” ( Marx, 2013, p. 255-256).
} 
atividade humana propriamente dita, mas não se confunde com essa. Em síntese, o trabalho é originário da constituição do ser social e as demais categorias tem características puramente sociais posteriores à constituição do ser social, nos termos de Lukács:

\begin{abstract}
Somente o trabalho tem, como sua essência ontológica, um claro caráter de transição: ele é, essencialmente, uma inter-relação entre homem (sociedade) e natureza, tanto inorgânica (ferramenta, matéria-prima, objeto do trabalho etc.) como orgânica, inter-relação que pode figurar em pontos determinados da cadeia a que nos referimos, mas antes de tudo assinala a transição, no homem que trabalha, do ser meramente biológico ao ser social (...)

Desse modo, o trabalho pode ser considerado o fenômeno originário, o modelo do ser social; parece, pois, metodologicamente vantajoso iniciar pela análise do trabalho, uma vez que o esclarecimento de suas determinações resultará num quadro bem claro dos traços essenciais do ser social. (Lukacs, 2014, p.35)
\end{abstract}

Ainda mais, deve-se considerar a distinção qualitativa da dimensão ontológica e histórica, sendo que o processo de trabalho sempre teve a pré-condição dos modos de produção de estabelecidos e a aplicação de uma forma social para a execução de um trabalho (Lukács, 2014 e Marx, 2011). Do mesmo modo, o processo ontológico e o processo de trabalho na vida cotidiana comportam momentos distintos conforme Marx no capítulo "Processo de Trabalho e Processo de Valorização" em O Capital, Livro 1 (Marx, 2013). Assim sendo, Mendes-Gonçalves expõe graficamente o processo de trabalho como elemento constitutivo da tríplice relação dialética que inclui o homem e a natureza. O autor ampara-se em Meszáros para tal definição, contudo, em sua representação a tríade é sintetizada nos elementos: homem; natureza; e indústria ${ }^{28}$ (Mészáros, 2006, p.100). A atividade produtiva exposta por Meszáros refere-se a caracterização histórica no capitalismo. Logo, não atribui caráter ontológico em construções históricas, atribuições imprecisas presentes em trechos específicos de Mendes-Gonçalves.

Por todas essas considerações, advogamos que o termo condizente seria a categoria, trabalho, mais ampla da ação humana e não processo de trabalho mais estrito. Nesse sentido "que não se deve exagerar de maneira esquemática esse caráter de modelo do trabalho em relação ao agir humano em sociedade” (Lukács, 2014, p.37),

\footnotetext{
${ }^{28}$ No exemplo citado, não ignoramos a possibilidade do equívoco ocorrer por questões de diferentes traduções da obra de Meszários
} 
conjunto da sociabilidade, o ponto de partida do trabalho como forma originária diz pouco sobre a realidade a ser apreendida. Interpretamos e desenhamos a hipótese de que a redução da categoria trabalho para o processo de trabalho, gera imprecisão da referência ao processo específico e histórico na sua dimensão concreta, desse modo, restringiu o entendimento da categoria trabalho em períodos da sua obra e significou a construção de categorias alternativas como a acepção ampla de tecnologia ao invés da conceituação de trabalho complexo, intelectual, organização do processo de trabalho e principalmente, do trabalho social combinado.

A despeito de imprecisões teóricas, Mendes-Gonçalves fundamenta ontologicamente o trabalho em saúde. Aprofunda a discussão homem e natureza considerando o primeiro parte do todo representado pelo segundo, por não se tratar de relação de oposição, porém, distinta qualitativamente, da intencionalidade humana dos eventos naturais-causais, tem na teleologia sua marca, o desenvolvimento das potencialidades humanas são provenientes da natureza ${ }^{29}$.

Desse modo, explana o porquê da construção social do equívoco de não se tratar a prática em saúde enquanto trabalho. Mendes-Gonçalves reconhece a existência particularidades na produção em saúde que forjam o equívoco construído socialmente de desvincular a prática em saúde da categoria trabalho. O autor expõe:

\begin{abstract}
Alguns tipos de trabalho humano, mais do que outros, mesmo no contexto de culturas e sociedades diferentes e em momentos completamente diferentes da história, são mais facilmente desvinculados da ideia geral de "trabalho", aparentando serem formas de atividades distintas, mais nobres, mais livres de injunções materiais que costumam estar associadas ao estereótipo do "mundo do trabalho" como algo pesado, sofrido, repleto das leis férreas da necessidade e distante da criatividade e da liberdade. Dentre esses tipos de trabalho, um dos mais notáveis é o trabalho em saúde, principalmente se reduzido à atividade de seu trabalhador mais típico, e em muitos sentidos principal, o médico.

Se são mais facilmente desvinculados é porque certamente são mais facilmente desvinculáveis: esse equívoco do pensamento, para que possa ocorrer e reiterar-se, deve estar necessariamente baseado em características objetivas do
\end{abstract}

\footnotetext{
${ }^{29}$ Essa consideração é fundamental para a teoria marxiana da história apresentada pelo autor, em seus termos:

“Ora, o que aqui evidencia a distinção do homem (parte) na natureza (todo), que bem pode também ser apreendido na teoria de que os homens fazem sua própria história, embora em condições previamente dadas, é a presença nele, homem, diferentemente dos reinos mineral e vegetal, e do restante do reino animal, da teleologia, enquanto todas essas outras partes da natureza apresentam, como ele, causalidade, mas não teleologia" (Mendes-Gonçalves, 2017, p.304)
} 
trabalho em saúde - que não obstante quaisquer equívocos segue sendo um trabalho - que o diferenciam de modo peculiar no contexto da divisão social do trabalho. E ao mesmo tempo, necessariamente, como esse equívoco não ocorre em nenhum conjunto abstrato de cérebros, mas sim na realidade mais inclusiva das práticas sociais, (...). Desde já se pode adiantar que entre as características que baseiam esse equívoco, ganham especial relevo: 1) o peso aparentemente maior das dimensões intelectuais do trabalho sobre as manuais; 2) a associação mais direta entre os valores ligados a seus produtos e os princípios ideológicos mais importantes no processo históricos de estruturação/desestruturação/reestruturação das sociedades capitalistas ocidentais, nas épocas moderna e contemporânea; 3) a posição social situação nas hierarquias e estratificações sociais - que é obtida e reproduzida mediata e imediatamente através do trabalho pelos agentes sociais que o realizam. (MENDES-GONÇALVES, 2017, p.301)

Na passagem acima, o autor expõe como a partir da dimensão concreta do trabalho em saúde, os homens constroem uma abstração que não é mero equivoco, mas uma construção ideológica enraizada nas práticas sociais. $\mathrm{O}$ autor desvela os aspectos ideológicos das práticas de saúde para analisar a categoria trabalho que não encerra em si a reflexão sobre a prática de saúde que comportará outros elementos da realidade, não sendo possível determinado reducionismo, mas é aspecto central.

Analisando o pensamento em saúde de Mendes-Gonçalves, as considerações do autor não são meras exposições do pressuposto filosófico de Lukács, pois a reflexão sobre a prática social em saúde é deveras original. Implicitamente, nessas passagens acerca do homem e natureza, estão as considerações do corpo como "natureza humanizada" e que as intervenções do trabalho em saúde agirá de forma teleológica sobre uma configuração orgânica estabelecida. Nesse meandro, a ontologia do ser social se depara com a construção da história humana, na qual as intervenções sobre o corpo relacionar-se-ão com as condições do inerentemente naturais, mas sobretudo pela sociabilidade entre os homens, logo, os carecimentos e as necessidades em saúde comportarão uma amplitude de elementos para além do orgânico.

\subsubsection{O Trabalho em Saúde na Forma Histórica do Capitalismo}

Nas trilhas de Donnangelo, a partir do diagnóstico da crescente associação entre medicalização e mercantilização da sociedade capitalista, Mendes-Gonçalves caracteriza o trabalho contemporâneo em saúde, em seus termos:

"O trabalho em saúde reorganizou-se e desenvolveu-se nas sociedades capitalistas ao redor desses dois eixos acima citados: como forma de controlar a doença em escala social relativamente ampla e de forma efetiva, como forma 
de recuperar a força de trabalho na mesma escala e finalmente, como forma de ampliar efetivamente os direitos e o consumo das classes subalternas" (Ibid, p.351)

Esse processo associado condiciona o trabalho em saúde. Não obstante, a instituição do hospital contemporâneo ocorreu pela lógica militar (Foucault, 2002), esse é o primeiro lócus da organização capitalista do trabalho em saúde, sendo o elemento histórico fundamental das estratificação das ocupações em saúde, de acordo com MendesGonçalves:

\begin{abstract}
Instituição relativamente grande e complicada, o hospital levou ao aparecimento de toda uma coleção de trabalhos "infra-estruturais", sem os quais não pode funcionar, e que se constituíram na primeira extensão do médico em um trabalhador coletivo. $\mathrm{O}$ mais importante desses trabalhos foi o do enfermeiro, encarregado sobretudo de funções relativamente "mais manuais", associadas ao processo terapêutico, e de funções complementares, não obstante essenciais, à realização do processo como um todo. A preservação do núcleo " mais intelectual” (Diagnóstico e prescrição, além de certas técnicas privilegiadas) manteve o médico como dominante e determinante do processo. (Ibid,p.355)
\end{abstract}

Amparado na historiografia foucaultiana, o autor descreve como a dinâmica do hospital conforma as profissões de saúde, em um processso contraditório de especialização e complexificação do trabalho coletivo em saúde. Sobre a divisão capitalista do trabalho em saúde, o autor assinala:

"Ao mesmo tempo em que se dividia internamente - "verticalmente", em uma
metáfora espacial - o trabalhador médico coletivo passou a se dividir também
"horizontalmente", em etapa histórica posterior. Essa divisão "horizontal"
comporta dois tipos de expressão: a constituição de profissionais médicos
especializados em partes dos processos diagnósticos e terapêuticos, e a
agregação de outros profissionais com áreas de atuação complementares: o
odontólogo, o fonoaudiólogo, o terapeuta ocupacional, o fisioterapeuta, o
psicólogo, o assistente social, o cientista social e o administrador. "(Ibid, p.357)

O autor destaca o caráter social da dimensão técnica do trabalho, em seus termos:

Do ponto de vista exclusivamente e abstratamente técnico, nenhum desses postos de trabalho do trabalhador médico coletivo é dispensável, e, portanto, naturalmente subalternos seus agentes, mas a técnica não existe isolada de sua apropriação diferenciada na reprodução das diferenças de classe, e o controle dos momentos "mais intelectuais" do trabalho garante o poder sobre o conjunto do processo, além de outras hierarquizações sociais importantes.

Reproduz-se dentro do trabalhador médico coletivo, dessa maneira, dentro de certos limites, o mesmo tipo de dinâmica geral característica de reprodução social, acarretando contradições que opõem, deum lado, uma racionalidade puramente técnica, mas abstrata, e de outro lado, a necessidade de reprodução de relações sociais, em si mesma também abstrata. A rigor, esses dois polos contraditórios só existem em sua unidade, de tal forma que um põe limites à 
plena expressão do outro, já que se dá um através do outro: a divisão técnica do trabalho através da divisão social do trabalho, e vice-versa. A história social da medicina, olhada do ângulo da organização interna dessa prática, é história das soluções e impasses criados e recriados ao redor dessa contradição (Ibid, p.356-357)

\subsubsection{A Teoria das Necessidades em Saúde}

A partir do preâmbulo do caráter ontológico do trabalho Mendes-Gonçalves desenvolve a teoria das necessidades em saúde. O autor estabelece a correspondência entre os processos de trabalho e os carecimentos e as necessidades humanas ${ }^{30}$, o autor advoga:

Só existem carecimentos vinculados a objetos, decerto, mas a essa altura da conceituação, o carecimento importa apenas enquanto confere ao movimento do conjunto do processo de trabalho uma finalidade, um caráter teleológico. (Mendes-Gonçalves, 2017, p.333)

Em sua obra, o paralelo estabelecido entre processos de trabalho e necessidades é contínuo. O trabalho corresponderá ao carecimento, esse não se resumirá as necessidades básicas, mas relacionar-se-á ao processo histórico social de constituição de necessidades condicionados pelos meios de produção da vida. As relações sociais capitalistas se desenvolveriam conforme os indivíduos efetivariam trabalhos e reproduziram necessidades no (e do) modo de produção (Ibid, p.333). A concepção materialista das necessidades não se confunde com um determinismo economicista vulgar, porque se coloca muito além de aspectos técnicos. $\mathrm{O}$ atendimento das necessidades vitais é condição sine qua non para a vida humana e social. À medida que as necessidades básicas são saciadas, novas necessidades mais complexas surgem exigindo do homem processos de produção da vida que as saciarão. Os meios construídos e dispostos pelo homem para produzir são fundamentais na esfera social, todo o desenvolvimento histórico está presente nas relações de saúde.

Destacamos o percurso teórico da linhagem marxista acerca do tema. Na chave interpretativa de Donnangelo (1976), o autor utiliza o referencial do normal e biológico de Canguillem (2009), especificamente, da definição do objeto da medicina se situar fora dela. Nesse sentido, temos o desenvolvimento teórico da prática médica em dois âmbitos:

\footnotetext{
30 "Entenda-se, portanto, o processo de trabalho como contendo, sob a forma de um de seus momentos, a correspondência a um carecimento (C) que o "algo depois" é capaz de satisfazer."(Ibid, p.333)
} 
a articulação com outras práticas sociais e a teoria acerca das necessidades em saúde que não podem ser reduzidas primariamente a dimensão anátomo-fisiológica. Donnangelo cita a passagem a seguir de Boltansky:

\begin{abstract}
"Somente através da relação que os indivíduos mantém com o seu corpo é possível romper com a teoria naturalista das necessidades e das funções (...). Esta teoria tende a ver em cada consumo particular, em nosso caso o consumo médico, a expressão direta de uma necessidade específica preexistente - em nosso caso a "necessidade sanitária" - espécie de necessidade primária cuja natureza seria idêntica em todas as épocas e em todos grupos sociais"(Boltansky apud Donnagelo, 1976, p.26-27)
\end{abstract}

Nesse sentido, Donnangelo observa:

\begin{abstract}
“a compreensão do modo pelo qual a sociedade toma seus corpos, os quantifica e lhes atribui significado cultural, política e econômica é indispensável para explicar as formas assumidas pela prática médica, sem que com isso se pretendesse também afirmar que todos os elementos que constituem o campo da medicina são estruturados fora dela. Encontra-se ainda por fazer uma história da medicina capaz de dar conta, sistematicamente, das determinações econômicas e políticas do corpo e de sua relação com as formas históricas da produção médica" (Donnangelo, 1976, p. 27)
\end{abstract}

A considerável dedicação teórica na discussão das necessidades em saúde por parte de Mendes-Gonçalves a partir do apontamento de Donnangelo, trata-se do entendimento da totalidade relação social em saúde. Mendes-Gonçalves supera os termos anteriores da reflexão ao deslocar a concentração da prática médica para a categoria abstrata trabalho em saúde, do mesmo modo reciproco, os elementos culturais, políticos e econômicos se expressam historicamente e ontologicamente nas necessidades em saúde. Logo, as necessidades "necessárias" são históricas para a reprodução do homem nas diversas sociedades concretas. A relação dialética entre necessidades e processo de trabalho é expressa pelo autor nos seguintes termos:

"Deve-se notar que essa sócio-historicidade é a contrapartidada sócio-
historicidade dos processos de trabalho, que criam os objetos para as
necessidades, enquanto ao mesmo também o inverso é verdadeiro, já que as
novas necessidades criam os sujeitos para os novos processos de trabalho.
Deve-se notar ainda que as necessidades "necessárias", assim concebidas, são
sempre objetualizadas, só podendo ser adequadamente definidas nessa relação
com os objetos (produtos) que resultam dos processos de trabalho. Não há,
necessidades "necessárias" de ainda-não-objetos"(Mendes-Gonçalves, 2017,
p. 327)

Nessa perspectiva do ciclo dialético do trabalho e das necessidades, a teleologia humana sintetiza-se no "encontro" de finalidades: o indivíduo na atividade laboral e seu produto de trabalho e o indivíduo com determinado carecimento. Desse modo, tanto a projeção do objeto de trabalho quanto do carecimento são históricos e a análise não deve 
ter uma visão parcial de destacar unilateralmente um dos pólos: a produção ou consumo em saúde, a assistência ou demanda, mas justamente a síntese dessa relação na totalidade constituída (Ibid, p. 313) ${ }^{31}$.

O autor insere a contribuição de Heller (1986) na teorização das necessidades em saúde, em que ela retoma três momentos constitutivos da necessidade do ser social em Ideologia Alemã, de acordo com passagens clássicas de Marx:

“(...) o primeiro pressuposto de toda a existência humana e também, portanto, de toda a história, a saber, o pressuposto de que os homens têm de estar em condições de viver para poder "fazer história". Mas, para viver, precisa-se, antes de tudo, de comida, bebida, moradia, vestimenta e algumas coisas mais. O primeiro ato histórico é, pois, a produção dos meios para a satisfação dessas necessidades, a produção da própria vida material, e este é, sem dúvida, um ato histórico, uma condição fundamental de toda a história (...)

O segundo ponto é que a satisfação dessa primeira necessidade, a ação de satisfazê-la e o instrumento de satisfação já adquirido conduzem a novas necessidades - e essa produção de novas necessidades constitui o primeiro ato histórico (...)

A terceira condição que já de início intervém no desenvolvimento histórico é que os homens, que renovam diariamente sua própria vida, começam a criar outros homens, a procriar - a relação entre homem e mulher, entre pais e filhos, a família (...) (Marx e Engels,2007,p.32-34)

Os três momentos observados da necessidade do ser social constituem a relação reciproca com o trabalho humano na produção da vida social. Marx prossegue:

(Quarto momento) A produção da vida, tanto da própria, no trabalho, quanto da alheia, na procriação, aparece desde já como uma relação dupla - de um lado, como relação natural, de outro como relação social -, social no sentido de que por ela se entende a cooperação de vários indivíduos, sejam quais forem as condições, o modo e a finalidade. (Ibid, p.34)

Mendes Gonçalves desenvolve as necessidades em saúde com o pressuposto da produção da vida social e com atenção especial para a constituição históricas dos vários momentos das necessidades. Por se tratar de teoria com alto nível de abstração operado não se deve deduzir uma certa simplificação esquemática para a abordagem concreta das múltiplas situações, a chave de interpretação do autor mencionar os termos fundamentais que não podem ser ignorados: "compreensão da vida concreta dos homens ...compreender sempre os processos de trabalhos e os carecimentos como compondo estruturas reciprocamente relacionadas quere cobrem o conjunto da vida social" (Ibid.

\footnotetext{
${ }^{31}$ Passagem inspirada na seção “a) Produção e Consumo” em Uma Contribuição para a Crítica Da Economia Política (Marx, 1999)
} 
p.324). No entendimento dos carecimentos, a abordagem "objetivista" ou naturalista é insuficiente $^{32}$, pois a socialidade e a história a compõe, logo não serão fixamente determinadas. A necessidades nunca serão exclusivamente naturais ${ }^{33}$, embora tenham raiz na natureza, sobretudo, por exemplo, o aspecto essencialista da natureza corpórea (alimentação, fisiológicas, entre outras) se combina com a sociabilidade capitalista e na história das demais sociedades e sua reprodução, dessa maneira, esboça e a perspectiva emancipatória na reflexão de necessidades em saúde.

O autor assinala as características das necessidades necessárias e radicais no constructo teórico de Heller (1986). As necessidades necessárias sintetizariam o caráter contingente e característico da forma histórica de vida, desse modo, todas as mediações da vida na sociedade capitalista estão permeadas por tal necessidades. Por exemplo, a reconstituição da força de trabalho não encerra as necessidades sociais capitalistas em saúde, assim como, a expressão isolada do consumo também não expressa a sociabilidade da produção e circulação de mercadorias exige mediações mais complexas objetivas e subjetivas. As necessidades necessárias em saúde se apresentam na concentração do consumo de assistência à doença, mas também na redução do indivíduo à condição de paciente com um corpo doente demandante de intervenção. Em caráter de superação as necessidades radicais emergem dos indivíduos da mesma forma histórica, todavia, expressam a perspectiva emancipatória humana transcendente do modo de produção e das formas reificadas de vida. $\mathrm{O}$ autor distingue os dois tipos de necessidade, em seus termos:

\begin{abstract}
Ora, é precisamente esse o sentido que tomam, no capitalismo, aquelas necessidades "necessárias" especiais acima referidas: não são necessidades de ampliação quantitativa do consumo, pois essas, se não podem ser inteiramente satisfeitas, são, no entanto, perfeitamente funcionais, mas sim, necessidades de diversificação qualitativa do homem. Essas necessidades "necessárias" "necessárias" porque têm de estar presentes, por força da própria lógica do desenvolvimento do capitalismo — não podem, entretanto, ser satisfeitas, salvo em um movimento de transcendência da estrutura de poderes que as geram. A elas se aplica o conceito de 'necessidades radicais'.
\end{abstract}

\footnotetext{
32، As necessidades aparecem como aquilo que precisa "necessariamente" ser satisfeito para que esse ser continue sendo um ser.”( Ibid, p.325)

33،“...) alimentar-se, por exemplo, mas específicas quanto ao conteúdo e à forma: precisa alimentar-se de um certo modo, comendo coisas específicas e de uma maneira específica, pois só assim se reproduz como ser humano, ser natural sócio-histórico.” (Ibid, p.326)
} 
As necessidades radicais expressam a confluência da causalidade (elas não vêm "de fora", mas de dentro da própria estrutura histórica de reprodução da socialidade: traduzem suas tendências imanentes objetivas) com a teleologia (elas não são um tipo-ideal, mas um tipo empírico, idêntico à existência de seus portadores, que necessitam "necessariamente" a remoção dos obstáculos sócio-históricos à sua satisfação). (Mendes-Gonçalves, 2017, p.332)

A materialização das necessidades, ou melhor a objetualização das necessidades significa que os homens projetam sua finalidade sobre objetos e situações previamente dadas pelas condições humanas estabelecidas. Por exemplo, indivíduos de outras sociedades em outras épocas históricas não projetariam a necessidade de se submeter a intervenção cirúrgica em uma situação de agravo de saúde, porque tal configuração não está presente em sua forma social. O autor aborda o vínculo da objetualização e necessidades nos seguintes termos:

$\mathrm{Ou}$ em outros termos ainda, do conjunto de necessidades "necessárias", sócio historicamente produzidas, objetualizadas, conscientes, individuais, destaca-se um subconjunto que se opõe, porque opõe seus portadores, ao modo de reprodução histórico da socialidade; esse subconjunto, também foi sóciohistoricamente produzido, também é objetualizado, também é consciente, também é individual, e configura, para seus portadores, mais do que uma necessidade, um dever moral, que traduz a necessidade (besoin, need, Bedürfnis) de efetivação das possibilidades imanentes de "enriquecimento humano" já configuradas, e se expressa na necessidade (nécessité, necessity, notwendigkeit) de constituir-se e expandir-se como sujeito ético de forma objetivamente congruente com sua gênese e diferenciação (Ibid, p.331)

A dinâmica do social na constituição da estrutura de necessidades envolve os indivíduos que entenderão determinadas necessidades como se fossem exclusivamente suas. Assim sendo, necessidades contingentes elaboradas na sociabilidade capitalista terão a legitimação como interesse geral e a realização das necessidades alternativas serão “interditadas por ilegitimidade" (Mendes-Gonçalves, 2017, p.366), isto é, não serem funcionais a reprodução social. A reprodução da estrutura de necessidades pressupõe o processo histórico envolto por “ "presumível geral” passam por cima das necessidades conscientes dos indivíduos e justificam-se, antes e depois, por seus resultados técnicos" (Heller apud Mendes-Gonçalves, 2017, p.329).

Nessa perspectiva, o caráter alienado e fetichista na sociedade capitalista “cristaliza" os seus valores em necessidades, para a superação da contingência. O encontro das necessidades necessárias e a constituição das necessidades radicais poderá ser realizado pela práxis de um sujeito coletivo que esboçaria outra forma de sociabilidade emancipadora, que nos dizeres do autor se explictam como: 


\begin{abstract}
"A constituição desse sujeito coletivo dotado de um dever não de uma utopia, no sentido usual desse termo implica a tendencial generalização do núcleo radical de suas necessidades "necessárias", o que equivale à constituição efetiva de um novo valor histórico objetivo, por um lado, e à requalificação como antivalores objetivos, por outro lado, das necessidades que expressam tão somente a inércia da estrutura social. Se esses antivalores objetivos (no sentido de sua gênese e de sua configuração histórica, não de nenhuma característica si" que contenham) são identificáveis em princípio, por referência à estrutura sócio-histórica capitalista de reprodução da sociedade, são no mais especificamente na fetichização das necessidades. Se a fetichização capitalista das necessidades, a culminância histórica do processo mais geral da alienação do homem, pode assim ser tomada como o critério objetivo geral de discriminação das dimensões de antivalor presentes tanto na estrutura de necessidades "necessárias" como, obrigatoriamente, nos processos de trabalho e elas correspondentes, haverá, entretanto todo um universo de mediações entre esse critério geral e suas formas particulares e individuais de objetivação(...) (Ibid, p.332)
\end{abstract}

As necessidades radicais do ser social da humanidade não alienada ou a expressão na práxis do sujeito coletivo podem ser materializadas por meio de processos de trabalho não estranhados ou reificados. Com a mediação estabelecida de não negar eticamente as necessidades necessárias constituída na reprodução capitalista apresentadas pelos indivíduos, mas identificar seus limites e constituir novas práticas para sua superação.

1.3.5 Conformação Técnica do Processo de Trabalho e as Necessidades Necessárias do Capitalismo

No desfecho do texto, o autor aponta aspectos interessantes sobre a configuração do trabalho contemporâneo em saúde e indica perspectivas de superação da forma alienada. Em sua apreciação, a incorporação de instrumentos nos processos de trabalho reflete uma "necessidade social" capitalista de consumir produtos de outros setores. Desse modo, as indústrias de equipamentos e de medicamentos tem uma proeminência sobre o processo de trabalho e essa incorporação não se justifica exclusivamente pela dimensão técnica, mas por toda relação social envolvida de centralidade do poder econômico. A integração do trabalho médico ao conjunto dos trabalhos sociais, solidariamente e adequado as suas exigências, implica à especialização como resultante desse processo, ou seja, o recorte do objeto anteriormente sobre a natureza transformam o objeto de trabalho que deve ser efetivado com os meios e instrumentos adequados, produtos do capital em saúde.

A dinâmica capitalista configurou essa realidade, a busca incessante do lucro e o aumento da produtividade secundarizam as demais questões, inclusive, as centrais da intervenção humana sobre a saúde. A constituição de toda uma cadeia de produção se 
viabilizou pela ampliação das necessidades necessárias próprias da sociabilidade histórica do capitalismo. $\mathrm{O}$ autor esclarece:

O lucro do capital, investido diretamente em saúde, o lucro das empresas produtoras de bens e serviços consumidos no trabalho em saúde, a multiplicação dos postos de trabalho associados à necessidade de extensão permanente de cobertura de uma gama permanentemente ampliada de necessidades, tudo isso junto levou ao que costuma ser referido como "crise contemporânea da medicina", querendo-se com isso dizer que o gasto social no setor tornou-se desproporcionalmente grande em relação a outras demandas e em relação ao benefício dele decorrente.(Ibid, p. 359)

Mendes-Gonçalves desenha processualmente como as necessidades próprias do capitalismo incorporada pelos indivíduos trabalhadores e usuários fundamentam determinados processos de trabalho na produção e circulação de mercadorias "em saúde". Esses ditames conformam a prática médica e, consequentemente, as demais ocupações em saúde. Dessa maneira, a organização do processo de trabalho em saúde vincula-se a lógica de reprodução das estruturas de necessidades do capitalismo. O autor advoga:

Não se recupera a força de trabalho inutilizada por efeito da doença através de ações de vigilância epidemiológica; não se estabiliza a relação entre capital e população com antibióticos. Em outros termos, essas dimensões "externas" do processo de trabalho, que foram compreendidas como "necessidades sociais" do capitalismo em termos de saúde, devem encontrar correspondência adequada também com os momentos "internos" do processo, além de esses precisarem estar dispostos coerentemente entre si. (Ibid, p. 363)

Essa coerência do processo de trabalho e a dinâmica capitalista também é identificada nos modelos de atenção ou mesmo nas políticas públicas em saúde, desde a constituição da medicina social no capitalismo industrial ${ }^{34}$, embora o processo histórico não possa ser reduzido a correspondências mecânicas. $O$ autor entende que a discussão de modelo deve considerar tal pressuposto, então, referente aos modelos clínicos e epidemiológico que, se por um lado, o segundo abre possibilidades de práticas distintas,

34 “(...) práticas de saúde devem necessariamente estar referidas a "necessidades sociais”, isto é, a necessidades de grupos específicos de indivíduos que logram, exatamente por causa de sua objetivação pelo trabalho, alcançar o estatuto de necessidades "da sociedade", de todos os indivíduos. Nesse sentido, tanto o modelo epidemiológico, mas explicitamente em suas primeiras formas concretas — a Medizinischepolizei alemã e a "medicina urbana" francesa - quanto o modelo clínico, sobretudo no século XX, através dos mecanismos sociais de expressão do acesso ao consumo, são “medicinas sociais” (Ibid, p.363) 
contudo, se integra conforme as tendências das "necessidades sociais" do capitalismo, tendo aspecto diferenciado e complementar da mesma racionalidade do modelo clinico.

1.3.6 A Práxis em Saúde: A Conformação de Novos Processos de Trabalho e Modelos de Atenção

Mendes Gonçalves não ignora as proposições de modelos novos ${ }^{35}$ pretendentes da superação da mera complementaridade dos modelos na sociabilidade capitalista, mantém a perspectiva do materialismo histórico ao expor que as condições objetivas para a conformação de relações sociais radicalmente novas em saúde passaria por mudanças sociais históricas gerais com atuação política propriamente dita, em seus termos:

(...) em primeiro lugar, porque são "ideais" as condições de sua elaboração, faltando-lhes a base de objetivação das necessidades necessárias — neste caso, radicais - que permitiria sua contraposição às "necessidades sociais"; em segundo lugar, porque o espaço onde se geram as práticas e representações acerca das relações entre os processos de trabalho e a reprodução social deve ter sempre uma configuração política, irredutível - embora frequentemente reduzida - a uma problemática técnica( as "necessidades sociais" do capitalismo) faz com que essa oposição seja sempre posta secundariamente à sua integração. (Mendes-Gonçalves, p.364)

Em síntese, o autor diagnostica a contradição presente no desenvolvimento técnico-científico, na qual a humanidade tem condições de superar as antinomias do capitalismo, mas a reprodução capitalista se reafirma, critica a estrutura de necessidades sociais do capitalismo e a inerente reificação da vida social (coisificação do homem)

(...) em relação à estrutura de necessidades necessárias e ao lugar das necessidades de saúde dentro dela, para que às "necessidades sociais" do capitalismo não se venha opor nenhum outro conjunto abstrato de necessidades "sociais", capaz de transformar o homem, no máximo, em indivíduos despersonalizados, esmagado pela comunidade despótica de um capital social efetivado em forma estatal. (Ibid, p. 362)

Contudo, Mendes-Gonçalves se diferencia da visão pessimista da concentração nos aspectos regressivos ${ }^{36}$, tal apreciação refuta o nilismo da ação em saúde, esboça um

35 Por exemplo, a ação programática em saúde (Schraiber, 1990)

${ }^{36}$ É possível localizarmos semelhanças na análise de Mendes-Gonçalves $(1979,1994$ e 2017) e Illich (1973) acerca da relação entre medicina e capitalismo, contudo, a perspectiva política dos autores é díspar o primeiro tem o foco na proposição da transformação por meio da ação coletiva dos homens 
caminho em que as relações a partir do processo de trabalho objetivem e efetivem a "gênese das necessidades radicais de saúde" que deve perseguir "a mudança social". A oposição de modelos devem sempre ser relativizados, sua aposta política na conformação processos de trabalho vinculados as necessidades radicais visa a proposição a partir dos elementos históricos concretos da realidade histórica concreta e não em um modelo ideal. Desse modo, de acordo com o autor:

A constituição do sujeito da mudança histórica consistindo na práxis coletiva que assume como dever a superação das condições objetivas que bloqueiam a satisfação das necessidades radicais, segundo Heller (1986, pp. 87-113), presume a necessidade da própria teoria como necessidade radical: como no capitalismo se estabelecem mediações entre a produção da teoria e sua utilização na práxis, entretanto, a teoria vê-se obrigada a "seguir a pista" das necessidades humanas concretas, e a só saber ex post sua qualidade de teoria verdadeiramente objetiva. Como as necessidades radicais não são fantasmagóricas, mas necessidades conscientes, individuais, sócio-historicamente geradas e referidas a objetivações, todas as esferas da práxis relacionam-se de algum modo com as antinomias nelas inscritas de modo positivo, isto é: as necessidades radicais são necessidades de objetos reais, estão referidas às "necessidades existenciais", à cultura, ao descanso, ao relacionamento interpessoal afetivo e sexual, à educação, à saúde, etc. (Ibid, p. 362)

A busca de relações sociais em saúde emancipadas seria tarefa do sujeito histórico que se efetivaria na práxis que identificaria as necessidades radicais e os processos de trabalho não alienados a elas vinculados. A ação humana se efetiva no curso da história, logo o sujeito não existe sem a intervenção propriamente dita e a consequente, transformação. A práxis coletiva baseada no entendimento da necessidade radical em saúde pode superar as condições objetivas para mediações superiores a sociabilidade capitalista.

A amplitude da reflexão filosófica do autor na análise dos objetos concretos do trabalho em saúde e a perspectiva emancipadora é algo a ser destacado, embora o rigor acadêmico esteja presente e existe uma perspectiva político crítica que compila a socialidade, a história, sobretudo a práxis sustentada na filosofia da vertente da teoria crítica, e a perspectiva de ação. Nesse sentido, quando o autor utiliza o termo práticas em

na história, o segundo tem uma perspectiva de denúncia com caráter antimoderno na defesa da autonomia do indivíduo. 
saúde é com a concepção de práxis, sua ampla utilização no campo da saúde coletiva a aproximou da noção de "praticismo", interpretação muito distante do autor, que originalmente utiliza práxis com uma profundidade mais do que o sentido aparente do termo filosófico que combina reflexão e prática, mas ao sentido atribuído por Luckács que o por teleológico do trabalho está presente nas demais práxis sociais, sendo o trabalho como protoforma de toda ação humana e, consequentemente, das outras práticas. Tal formulação teórica servirá para o entendimento da concepção ampliada de saúde, pois a teleologia da intervenção se relacionará a causalidade naural, mas não haverá submissão total da natureza a teleologia humana, logo o tecnicismo presente nas práticas desvela mais elementos ideológicos do que concretos.

\subsection{A Integralidade do Trabalho Médico na Transição da Medicina Tecnológica na Contribuição de Lilia Blima Schraiber}

Em O médico e seu trabalho: limites da liberdade, Schraiber (1993) estuda a prática médica no país, através de detalhada compilação das histórias de vida de médicos ingressantes na vida profissional no período de 1930 e 1955 no Brasil, especificamente, em São Paulo. Na análise da autora, a tendência histórica de destituição do exercício liberal da medicina para a organização capitalista dos serviços é caracterizada como transição da medicina liberal à medicina tecnológica. Nos termos da autora tem-se que:

\footnotetext{
(...) do ponto de vista da organização dos serviços, de um lado, o conteúdo técnico do trabalho individual diferencia-se e multiplica-se nas especialidades médicas. De outro lado, transforma-se a base do trabalho: de princípio estruturador apoiado no exercício isolado de consultório, para unidades de serviço fundadas no trabalho hospitalar ou em clínicas ambulatoriais, tendo por conformação típica o trabalho coletivo. Trabalho, cuja composição qualitativa e quantitativa diferencia-se em padrões diversos na dependência da organização empresarial das instituições" (Schraiber, 1993, p.131)
}

A ampliação analítica sobre diversos aspectos de trabalho e de modo de vida nesse processo histórico para além da inserção do médico no mercado de trabalho e da propriedade dos meios é o aspecto diferencial em relação aos seus predecessores. A autora objetiva essa perspectiva no estudo da tecnologia em sua acepção ampla para compreensão da prática médica no país. Especificamente, define seu objeto como a análise do trabalho médico enquanto tecnologia. A primeira vista, a aparência limitadora do recorte, torna-se caminho para a análise sobre a totalidade, em seus termos "projeto global" do trabalho médico (Ibid, p.17). A autora chama à atenção para: 
O que afirmamos é que a incorporação de tecnologia não é só o que vemos ser na primeira percepção, qual seja, a inovação de técnicas ou a criação de equipamentos, mas, pelo menos da perspectiva de nossas questões, é também um movimento de preservar o exercício autônomo da prática médica. Também a autonomia não se reduz apenas à liberdade de prática, tal como parece ser, senão uma liberdade cujas especificações podem qualificá-la sob diversos compromissos constrangedores e conformadores do desempenho profissional. (Ibid, p.22)

Principalmente, por utilizar o termo tecnologia como constructo teórico referente as relações sociais amplas vinculadas à incorporação de equipamentos e ao processo de especialização, mas não restritos às essas dimensões. Em seus termos, a autora explicita:

(...) os médicos constroem um modo de pensar sua prática clínica, projetandoa e buscando realizá-las sob determinadas forma de atual. Seu estudo me permitiria, assim, alcançar não só o projeto tecnológico dos médicos, senão também as bases de sua formulação. E este projeto aderiu de tal modo à produção do cuidado autônomo e individualizado, que terminou por mitificála como modalidade símbolo da boa e adequada assistência. Creio que a expressão mais clara disso e o valor dado ao trabalho do consultório particular,fazendo com que este modo de exercer a prática pareça ser, para a medicina, a mais correta tecnologia de operação. (Ibid, p.15)\

Desse modo, Schraiber interpreta a relação social histórica estabelecida no trabalho médico e na organização do serviço, ou seja, da medicina como prática social, por exemplo, ao dedicar a atenção sobre a "reprodução discursiva" dos profissionais desvela o seu "modo de pensar" (Ibid, p.35) e valorizar determinados aspectos, aprofundando a temática para a apreensão de determinado ethos, entendido aqui amplamente como forma de conduta da vida da social e de representação simbólica. Em síntese, trata-se na análise mais completa do trabalho médico através da pesquisa empírica e aprofunda teses esboçadas anteriormente na escola de pensamento da teoria do processo de trabalho em saúde.

A exposição da autora do trabalho médico e do trabalho coletivo elucidam ponto de aproximação com Mendes Gonçalves (2017)

O trabalho médico, como veremos adiante, dirigido para a configuração de trabalho coletivo, organiza de forma muito própria sua arquitetura de interdependências e cooperação. Relembremos nesse sentido o fato de que a medicina se constitui como trabalho social de marca capitalista sob a forma "artesanal" de trabalho, ou ao menos na forma de atos individualizados de produção do cuidado médico, tal como surge a prática liberal. Parece, pois, lícito supor não apenas que a autonomia do médico, como forma específica de inserção deste agente, assuma o sentido de peculiar na estruturação capitalista daquele trabalho, senão sobretudo supor que, enquanto forma determinada socialmente, cristalize-se já tensionada pelo movimento de especialização que simultaneamente também caracteriza a mesma estruturação. (Schraiber,1993, p. 26) 


\subsubsection{A Pesquisa: A História pela perspectiva dos Agentes da Práticas}

A partir dos depoimentos pessoais das experiências dos indivíduos desenvolve aspectos reflexivos da integralidade do trabalho médico na sua dimensão concreta, ou melhor, do modo como homens e mulheres entendem suas práticas no trabalho e na vida. No transcurso do texto de Schraiber, a relação entre teoria e empiria ou, mais precisamente, a construção dialética da apreensão da realidade na relação concreto e abstrato estão presentes, a interpretação teórica está relacionada aos achados empíricos. A interpretação das narrativas dos indivíduos revela a expressão da prática tecnologizada e especializada, característica histórica principal da medicina e interpretada de modo abstrato a partir da multiplicidade dos elementos concretos (Ibid, 1993, p.221). Pela minuciosa apreensão do real e a elaboração teórica, a autora assinala a simultaneidade do processo que não procedeu a pesquisa separada em partes, descrição dos casos e posterior análise, por tal motivo apresenta na condicional o desenho da hipótese. Desse modo, a autora menciona que o desenho da hipótese não caberia plenamente ao seu estudo ${ }^{37}$. Em seus termos, a autora afirma:

\footnotetext{
Ao nos aproximarmos da base empírica, trazíamos um conjunto relativamente abstrato de "hipóteses" iniciais, que se constituiu precisamente no motor primeiro de uma capacidade, só então efetivada, de iniciar a produção dos dados empíricos. Essa produção, por sua vez, resultado da reflexão conjunta com os entrevistados, obrigou ao ajustamento constante daquelas hipóteses teóricas iniciais, em um movimento permanente de aproximação mútua entre o teórico e o empírico. (Ibid, p.221-222).
}

Entre os muitos aspectos, destacam-se as representações centrais dos entrevistados, por exemplo, a projeção valorativa da formação como médico como sinônimo de ascensão social. Tornar-se médico é um marco em suas vidas, sobretudo, pelo prestígio social alcançado, seja na expressão de poucos indivíduos de origem social não abastada e da maioria de imigrantes europeus, ou de famílias tradicionais de comerciantes, fazendeiros ou industriais para manter a posição da família. Todos relatam

\footnotetext{
37 "Caso assim o fizéssemos nossa "hipótese", termo não muito adequado a este estudo, seria a de que a dinâmica de incorporação de tecnologia é uma dinâmica de preservação da autonomia dos médicos no trabalho, autonomia essa que surge como característica principal de certa forma de exercício da profissão, a medicina liberal.” ( Ibid, p.22)
} 
seus esforços pessoais na escolarização para a formação e posteriormente do exercício liberal ${ }^{38}$.

Schraiber ao destacar aos históricos de vida demonstram que a projeção dos indivíduos acerca da formação médica passa ao largo das questões técnicas e científicas. Os médicos na lembrança de entrevistados eram "ilustres" 39 com influência importante e davam conselhos de ordem pessoal. Essa projeção do prestigio profissional se associa com a representação da autonomia. A distância do ideal da profissão na formação e a inserção inicial no mercado de trabalho também é relatada, principalmente, porque não ocorre "como prática tipicamente liberal", nos termos do entrevistado.

De outro lado, ainda que para todos seja o consultório o que de fato simboliza o trabalho profissional, o sentido que assume a convivência com as atividades sob vínculos empregatícios não é exatamente o mesmo para o conjunto dos entrevistados, parecendo mais lógico aos mais jovens dentre eles. Para este parecerá bastante plausível a necessidade de um emprego como a forma primeira e mais imediata da inserção no mercado de trabalho. (Ibid, p.49)

Nessa perspectiva, os relatos singulares demonstram concretamente como os médicos vivenciaram as tendências históricas na sociedade brasileira no período de mudança qualitativa da prática social. Desse modo, a trajetória profissional demonstra as relações de emprego em hospitais e laboratórios privados, bem como vínculos públicos

\footnotetext{
38 "Ressaltemos que para tanto é central o fato de que, até esse momento, o saber ainda representa o principal meio de trabalho, e sua posse, o recurso suficiente para que o médico se estabeleça na vida profissional. Ser médico podia ser assim simples como fazer-se médico por seu próprio esforço. As barreiras sociais representadas pela escolarização e a seguir pela instalação do consultório e a captação da clientela, ainda são nessa época passíveis de uma margem grande de transposição pelo esforço relativamente mais individual.
}

Não obstante, devemos relativizar um pouco essa última afirmativa, pois este esforço é apenas parte dos requisitos para ser médico: a própria camada social de origem dos entrevistados (na maioria filhos de comerciantes, fazendeiros, gerentes de indústrias grandes, funcionários públicos graduados) e a pequena presença de indivíduos originários de famílias de baixos recursos nas escolas médicas, tal como eles mesmos relatam, mostra como era socialmente difícil chegar à qualificação profissional pois a medicina era encanto, esperança, conquista A escolarização como promessa de "vencer na vida"” (Ibid, p.53).

${ }^{39}$ Conforme relato de médico entrevistado na pequisa de Schraiber "É verdade que os médicos, nessa época eram pessoas, assim, ilustres. Muito considerados! (...) Indiscutivelmente! Isso, todos os que eu conheci! Todos! Alguns até me recordo que se a gente comparar com o conhecimento que a gente tem hoje, eles eram ingênuos. Mas eram umas pessoas que tinham uma influência importantíssima! Alguns eram conselheiros de família ... que a pessoa ia lá no consultório dele pedir opiniões pra decisões e tudo. Até acerca... opinar sobre casamento de filhos! Eram coisas desse tipo. Então o médico tinha uma influência muito grande, mais do que as outras profissões, inegavelmente.” Ibid, p.52 
em parceria com o consultórios privados com exemplos de exercício de 30 a 50 anos. A autora através do depoimento de uma médica expõe, por exemplo, elemento da divisão sexual do trabalho e representação dos gêneros na relação das especialidades médicas, nos seguintes termos da entrevistada:

Pra começar, médica - mesmo clínica geral - não examinava homem, né? Aliás, acho que nem precisa. Hoje... tem quem trate de homem, né? Eu acho! Homem é sempre homem e mulher é sempre mulher e sempre... Não dá certo! Em geral, as médicas da minha época elas faziam Pediatria ou Clínica Geral, né? Mas aí, mais ligado a parte de senhoras mesmo. Não me lembro de ninguém fazer... clínica de homens, assim. Só atendiam mesmo senhoras, né? , vias urinárias só senhoras mesmo. Mas hoje, a gente vê aquela doutora famosa aí que faz muito bem moléstias ano-retais, né? Ela faz muito bem e faz Procto mesmo... (Ibid, p. 57)

Do mesmo modo, a valorização da clínica está presente no relato da médica vinculada a um determinado ethos, de acordo com a entrevistada.

E eu achei por exemplo, que a Clínica Geral era uma ... uma bela especialidade, mas não se adaptava muito ao meu temperamento de imediatista, prática e objetiva. Então eu achei que era difícil ser um bom clínico. E o bom clínico é o grande médico de hoje, né? E o bom... o bom clínico é o grande médico de amanhã e sempre. Era difícil ser um bom clínico. Porque... depende de muito estudo. Precisava estudar muito e naquele tempo os recursos eram muito pequenos e os resultados não eram palpáveis, por assim dizer. A área cirúrgica era mais... era mais objetiva, né? Era uma área mais prática, mais objetiva, resultados imediatos! (Ibid, p. 57)

A abordagem da integralidade prática médica não é mero fruto da hipótese teórica, mas sobretudo da metodologia empregada, a pesquisa social, especificamente, a realização de entrevistas permitiu à autora desvelar a tendência histórica através da interpretação em depoimentos pessoais. Embora o termo prática social fosse corrente no campo da saúde coletiva, a metodologia utilizada era comum até aquele momento no campo das ciências sociais ${ }^{40}$, tal aspecto da obra deve ser ressaltado, pois a autora empreende a pesquisa da história social com os postulados teóricos da escola fundacional da saúde coletiva com métodos empregados distintos dos autores fundacionais, especificamente, na referida escola de pensamento.

40 Curiosamente, tornou-se comum que estudos interpretativos acerca da teoria da saúde coletiva caracterizaram que a produção vinculada aos autores marxistas da década de 70 e 80 expunha teses gerais de caráter economicista e ignorava a vida real dos sujeitos e a dimensão da singularidade, particularidade e localidade (Minayo, 2001). Por tal situação a adoção de teorias sociais compreensivas foram necessárias na década de 1990, tais análises embora critiquem corretamente o predomínio do estruturalismo no campo marxista, esquecem de mencionar a contribuição de Schraiber sobre esse aspecto. 


\subsubsection{A Autonomia como Categoria Chave da Interpretação da Prática Médica}

Schraiber ampara-se em Freidson (2009) e destaca a constituição da profissão médica na qual o Estado é o grande promotor do monopólio da cura, mas resguardando a autonomia e autoregulação dos profissionais por se tratar de matéria técnica científica, em contrapartida a corporação médica fortalece o poder do Estado. Na historiografia foucaltiana (2003), a constituição da clínica é o elemento central do desfecho moderno na relação de saúde e do controle dos corpos pelo Estado nos séculos XVIII e XIX. A incorporação teórica da sociologia da profissão médica de Freidson ${ }^{41}$ significa o desenvolvimento do termo autonomia do trabalho médico no constructo teórico na teoria do processo de trabalho em saúde é traço original de Schraiber (1993) e desenvolve reflexões e desdobramentos de outra natureza em relação aos autores predecessores. A saber, mesmo em Freidson a autonomia é traço da constituição profissional da medicina com um elemento da legalidade própria, em Schraiber se insere em um contexto de totalidade histórica.

Depreende-se da trajetória profissional dos médicos que a organização dos serviços e o exercício liberal da prática médica não pode ser deslocado da realidade dos países capitalistas centrais para o Brasil, pois deve ser contextualizado na realidade brasileira. Principalmente, porque no país nos séculos XIX e XX, embora a industrialização e a urbanização motivaram o crescimento de escolas médicas, não se constituiu uma clientela considerável com renda para consumo dos serviços de saúde. Do mesmo modo, o contexto do exercício liberal, em que pese, o Estado seja agente político no processo de medicalização em todas as sociedades, na particularidade nacional o assalariamento é presente desde o início do século XX na provisão de empregos públicos. Observa-se a coexistência entre formas de organização da prática liberal e tecnológicaempresarial, relação salarial de emprego misto (público e privado) associado ao exercício do consultório. Então, quando a autora trata da transição da medicina liberal a medicina tecnológica, analisa a forma predominante, todavia não exclusiva de uma forma liberal

\footnotetext{
${ }^{41}$ Ao contextualizarmos a obra de Freidson vinculado tanto a escola de Chicago quanto a abordagem weberiana acerca da constituição das profissões observamos a diferença analítica com a leitura marxista de trabalho (Schmitz, 2014; Machado, 1997)
} 
sobre o regime assalariado no período de 1930 a 1960 para o estabelecimento final da medicina de caráter empresarial na década de $1960^{42}$ (Ibid, p.141)

$\mathrm{Na}$ constituição dessa relação particular de trabalho, o conhecimento técnico científico e a validação social na qual o médico deve operar pelo seu próprio discernimento na definição das intervenções é raiz histórica da autonomia, essa prática autônoma configurou-se na sociedade capitalista industrial como profissional liberal. De acordo com Schraiber (1993) essa relação demonstra-se pelo monopólio dos médicos sobre diversas esferas:

\begin{abstract}
Ademais conseguiram nesses domínios reservar para si mesmos a avaliação e a regulação de seus desempenhos: controle sobre outros e autocontrole é a fórmula bem-sucedida de prática e que representa o seu ideal. Esta é a forma de relação que os médicos pressupõem por referência aos demais agentes sociais, tanto quanto na articulação entre seus próprios trabalhos. Definindo as ordens de vida e de saúde, definindo as transgressões dessas ordens e definindo suas re-normarlizações, em atos que também só essa categoria profissional efetiva, como gerentes e juízes de si próprios, os médicos demarcam uma profissão que parece decorrer exclusivamente da conquista de uma autonomia de amplos domínios, cujo principal substrato tecnológico tinha caráter de tecnologia não material. (Ibid, p.167)
\end{abstract}

(...)

Fato similar dá-se na medicina, ao haver a adoção de uma prática técnica única (a prática médica); conferida sempre a um mesmo trabalhador (o médico); regulamentada subordinadamente a uma só forma de saber (a ciência das doenças); conferida por uma única via de qualificação profissional (a escola médica); e por todo esse conjunto, validada socialmente como a única forma legítima de serviço. Para que a prática médica moderna se constitua plenamente, ocorre, portanto, uma uniformização e unificação de todas as práticas "curadoras" que existiam até o final do século XVIII. Também se constrói um exclusivo saber a fundamentá-la: o conhecimento médico sobre o corpo doente; conhecimento que à mesma época já se havia reorientado na direção de único saber sobre as doenças (Ibid, p.180)

As características profissionais da medicina ou o posicionamento privilegiado na divisão social do trabalho não deve olvidar o fundamento da relação social que possibilitou aos médicos a legitimidade e o poder de intervenção técnica sobre o corpo doente vista como objeto de seu trabalho. Nessa perspectiva, o conhecimento da fisiologia e da biologia proveniente da revolução científica da modernidade, posteriormente, o

\footnotetext{
42 Apresenta-se a capitalização desse setor amplamente subsidiada pelo Estado, o que se verifica notadamente a partir dos anos 60. A década de 60 virá marcar, desse modo, o deslocamento definitivo do modelo liberal de prática.é a medicina tecnológica e empresarial.
} 
domínio biomédico fundamentaram o trabalho técnico de caráter reparador e mantenedor das condições vitais dos indivíduos conjuntamente com os princípios éticos acerca de intervenção sobre a vida do paciente. Embora, a medicalização opere determinada redução da condição humana à dimensão ánatomo-fisiológica, inegavelmente, essa visão do homem a condição orgânica é bem sucedida socialmente e reconhecida dessa prerrogativa para a normatização de toda vida social e a "sacralização" desse trabalho social. Nenhuma categoria profissional contemporânea ou corporação de ofício medieval sustentaria tal posicionamento se fosse motivada somente pelos sentimentos de autopreservação ou prerrogativa de monopólio sobre determinada a atividade, a atribuição da prática como talentosa, "misto de arte e técnica" que ideologicamente seria realizada por indivíduos dotados de "vocação" e "dom" é socialmente constituída nesse período histórico.

\begin{abstract}
A noção de profissão, no sentido acima, qualifica a prática dos médicos de "talentosa", misto de arte e técnica: técnica na arte, supremacia criativa de um proceder técnico eticamente adequado. A arte reside, pois, nessa capacidade de aplicar o técnico-científico sob preceitos "corretos" de comportamento pessoal. É um ouvir, um receber, um interessar, um confortar, um orientar, em que se dispõem as ações técnicas derivadas da ciência.

(...)

O recurso ideológico ao dom ou vocação, neste caso, representa o apelo ao transcendente para recompor esta radical separação que o próprio pensamento médico faz ao adotar aquela racionalidade científica, entre o sujeito e as "coisas da natureza", produzindo a curiosa simbiose de um "natural" nada natural constituindo o dom para a profissão. (Ibid, p.153)
\end{abstract}

De todo modo, a redução desse complexo processo histórico e social à dimensão técnica, naturaliza a técnica como desdobramento lógico correspondente à natureza e negligencia a relação peculiar conformada historicamente na modernidade entre os médicos e os demais sujeitos. A reconstrução do pensamento médico a partir da identidade social que representava uma condição objetiva, elaborou o "núcleo essencial da prática técnica" correspondentes "características "naturais e intrínsecas" de seu objeto - o corpo doente" sendo a organização da prática alicerçada nesse fundamento. Então, a relação entre o médico e o paciente colocará a autonomia como princípio de trabalho, tal dimensão embora compartilhe do ideário comum tem diferenças inclusive com demais 
trabalhadores com especialização técnica justamente pelo caráter relacional e o poder de intervenção sobre os aspectos vitais ${ }^{43}$.

No plano ideológico, embora a realidade não seja condizente ao postulado da representação de forma idêntica, essa exerce força real nas relações sociais estabelecidas entre os indivíduos. Nos termos da autora, tal relação aparece do seguinte modo:

\begin{abstract}
A representação conforma, porém, um pensamento que traduz as bases do trabalho em um discurso que ao mesmo tempo as enuncia e valoriza. Capta, por isso, a realidade material em uma imagem conforme com o valor que porta, tornando esta mesma imagem também uma justificação da existência social dessa realidade. Cria, desta forma, um dever-ser, uma ordem ideal que aparece como precedente às próprias bases materiais que originam a imagem. Consequentemente, esse pensamento especifica-se como capaz de conformar comportamentos, já que os sujeitos-agentes do trabalho procurarão realizar em ações o ideal contido na representação, retraduzindo o imaginário em realidade material de trabalho. Devemos, pois, qualificar a autonomia também neste plano, inserindo a análise do pensamento dos médicos sobre a profissão como parte do conhecimento acerca das questões do trabalho médico. Até porque, como veremos, o dever-ser perseguido é, no caso desse trabalho ferramenta tecnológica nada desprezível. (Ibid, p.28)
\end{abstract}

Os profissionais médicos formulam posições próprias acerca do seu cotidiano, logo esse processo histórico não é expresso de forma automática nas representações profissionais. Schraiber aponta a valorização do ideal de uma medicina tecnológica ou de uma prática tecnologizada. Contudo, esse modo de pensar como manifestação de uma ideologia guarda em si, uma contradição: a valorização da autonomia de trabalho ao mesmo tempo que valoriza o cotidiano pautado pelas tecnologias, principal elemento de destituição da autonomia. Esse último aspecto é justamente o elemento de incorporação do capital em assistência médica e em saúde que solapou as bases do exercício liberal e domínio dos meios dos profissionais médicos de outrora.

O choque das tendências conflitantes está presente na constituição da representação, onde a defesa do ideal autonomia refere-se a uma prática cotidiana em transformação. Nessa perspectiva, a autora fundamenta que a incorporação de equipamentos e instrumentos combinada pela crescente especialização do trabalho médico ao mesmo tempo conservam o ideal de autonomia em uma realidade histórica distinta. O período de transição é caracterizado como conformador de "estabilidadesinstáveis", contudo os profissionais não consideram que a própria prática está em 
transformação, nesse sentido, efetivam uma prática tanto especializada quanto individualizada mantendo a representação simbólica da autonomia, conformando uma "estruturação tensionada".

A impossibilidade do produtor autônomo e independente na transição da medicina tecnológica é expressão da necessidade da cooperação pelo trabalho social seja na forma da empresa capitalista, na associação comercial de profissionais com o compartilhamento de meios de trabalho e estruturas administrativas ou posteriormente, no modo de cooperativas, logo a organização do trabalho é ditada pela forma histórica da produção em geral. Indubitavelmente, em relação a inserção do agente no meio de trabalho operase uma "reordenação da autonomia" ou a constituição de "autonomias relativas", situações caracterizadas como de domínio parcial dos meios ou da clientela, nos dizeres da autora.

\begin{abstract}
Essa “autonomia contemporânea", que tanto se dá no consultório privado, quase empresarial como nas clínicas cooperativas, ou ainda através da inserção da consulta no espaço hospitalar, criando o consultório do hospital, vem de fato constituir uma alternativa. Pois mesmo assim transformadas, essas situações de autonomia de maior ou menor extensão e qualidade, seguem sendo situações de maior renda e maior prestígio profissional, daí que persistam enquanto ideal de trabalho. (Ibid, p.143)
\end{abstract}

Certamente, a caracterização dessa reordenação da autonomia contemporânea é relevante, visto que apesar das transformações da medicina empresarial e do assalariamento, ainda parte dos profissionais médicos gozam de inserções diferenciadas no mercado, maior prestígio ou mesmo benesses materiais em relação aos demais trabalhadores.

1.4.3 O Trabalho Coletivo em Saúde e a Autonomia como Estratégia Política: A Resistência Médica

O diálogo de Mendes-Gonçalves e Schraiber é nítido quando os autores abordam prioritariamente o trabalho médico, mas não como processo de trabalho isolado ${ }^{44}$, pois está inserido no trabalho coletivo em saúde fundamentam. A autora localiza o trabalho médico da totalidade histórica e posicionalmente ao conjunto dos demais trabalhadores, sem desconsiderar a dimensão própria dessa prática.

${ }^{44}$ Por exemplo, na abordagem de Arouca (2003) 
Assim, recortaremos da prática médica, individualizando, o problema eleito para o estudo - o trabalhador médico e a posição que ocupa no processo de trabalho. Este problema que examinaremos é sempre parte de um plural, de uma totalidade: não se deve tomá-lo por situação única, independente ou autônoma. De outro lado, porém, não se deve tampouco buscar nele somente o similar, o que contém, enquanto parte, de generalizável, como se não fosse ao mesmo tempo realidade singular. (Schraiber, 1993, p.22)

Em relação a dimensão política e a conformação de novos modelos assistenciais existe complementaridade de Schraiber (1992) e Mendes-Gonçalves (1979, 1994 e 2017), os autores apostam em novos modelos de trabalho no entendimento das práticas dos indivíduos no trabalho coletivo em saúde ${ }^{45}$.

A reflexão sobre a autonomia profissional dos médicos se desenvolve para além dos aspectos subjetivos condensado na expressão "modo de pensar" e analisa a dimensão política desse profissional no seu meio de trabalho e na sociedade em geral. Assim sendo, a despeito da estratificação interna da profissão ${ }^{46}$, a defesa do ideal de autonomia transforma-se em estratégia política e, de certo modo fundamenta, a resistência dos médicos a processos coletivos ou modelos de atenção que "ameaçem" o exercício do cuidado individualizado com domínios absolutos das prerrogativas do diagnóstico e terapêutica. A autora destaca em seus termos "significar a autonomia uma estratégia de poder, não estamos querendo apontar para um sentido moral e maniqueísta de uma ação pessoal" (Ibid, p. 173).

Por conseguinte, o processo contraditório de transformação e preservação do caráter da autonomia altera a dimensão política vinculada a essa forma. No período da constituição moderna da clínica até meados do século XX, o oficio médico no exercício liberal representava barreira ao movimento do capital, a incorporação tecnológica e a predominância do capital e do Estado sobre os serviços de saúde alteram o caráter da resistência, tais como, para o enfrentamento por exemplo modelos alternativos de assistências “não-biomédicos”. Dessa maneira, teoriza acerca de aspecto presente, porém, analisado superficialmente nas práticas: a postura do médico relação ao trabalho coletivo e os demais processos de trabalho. A perspicaz observação da resistência dos profissionais

\footnotetext{
${ }^{45}$ A experiência dos autores no Centro de Saúde Escola representa essa dimensão praxiológica.

${ }^{46}$ Há grande distância entre os médicos-comuns e os intelectuais na participação política e ideológica para a formulação do projeto de organização da medicina (Ibid, p.174)
} 
médicos em relação a novas formas de prática independentemente da efetividade revela que a dimensão técnica não é desassociada da sociabilidade, a autonomia torna-se manifestação de resistência

A autora não trata da dimensão scricto sensu do corporativismo, todavia, o desenvolvimento de sua caracterização permite a interpretação histórica de situações contemporâneas de manifestações conservadoras, na qual embora o capital apresente uma tendência de precarização e intensificação sobre o trabalho médico, esse ainda resguarda melhores condições em relação aos demais profissionais, porque ainda goza de relativa herança do caráter peculiar na constituição do trabalho médico no capitalismo associado aos interesses de Estado. 


\section{Capítulo 2: Leituras Críticas da Modernidade e Teoria Social em Saúde}

Nos comentadores, a caracterização da contribuição dos autores fundacionais oscila entre a constituição de um pensamento social em saúde (Castellanos, Loyola e Iriart, 2014; Nunes, 2008 ) ou a proposição de uma "teoria social da medicina como prática social" (Tambellini in Arouca, 2003 p. 52). Em nosso entendimento, a noção de pensamento configura-se como forma de reflexão mais ampla sobre os objetos da saúde, doença, corpo entre outros aspectos. Contudo, a construção de uma teoria social implica balizamento em pressupostos filosóficos em comum ou de associações desses para a interpretação da ação dos agentes na realidade e do todo social. Indubitavelmente, esses autores como demais da medicina social latino-americana constituem latu sensu um pensamento social, contudo, também é significativo que Arouca e Donnangelo e sua escola de pensamento constituem uma teoria social original em saúde, todavia, não se trata da conformação de paradigmas da teoria social, pois se fundamenta na associação de teorias críticas da modernidade capitalista e é pluriparadigmática.

Porquanto, independente da diferenciação entre pensamento social ou teoria social em saúde, enfatizamos a produção teórica original na investigação dos objetos de pesquisa relacionado ao entendimento social da saúde a partir da estrutura pluriparadigmática para interpretação da ação social e do conjunto das relações envolvidas no processo histórico. As teorias sociais da modernidade e do capitalismo constituem o repertório clássico das ciências sociais, a formulação teórica original a partir da associação das teorias críticas da modernidade foi recurso necessário para apreensão das temáticas analisadas. Embora, as contribuições tenham focos distintos compartilham de preocupações e proposições comuns. A definição da teoria como clássica em saúde justifica-se porque essas obras se tornaram referência histórica que marcaram época e fundamentaram o movimento da reforma sanitária no contexto da redemocratização do país que teve seu ápice na $8 \mathrm{a}$ Conferência Nacional de Saúde na década de 1980.

Desvelar as associações teóricas realizada pelos autores inaugurais da saúde coletiva pode explicitar a contemporaneidade de suas teses, assim como, cabe interrogar no campo da saúde coletiva: é possível produzir conhecimento desprovido de teoria social ou mesmo com pouca fundamentação em paradigmas diversos e, muitas vezes, "utilizado" incoerentemente? 
Nesse sentido, argumentamos que o campo da saúde coletiva opera relativa redução dessas contribuições, frisando a elaboração que nos "autores inaugurais" da determinação social do processo saúde e doença, não obstante os autores possam compartilhar dos pressupostos dessa formulação, essa é parte integrante de compreensão teórica crítica mais ampla. Em tempo, a formulação da determinação social que provavelmente fora realizada pioneiramente por Berlinguer (1972) e Conti (1972) no debate da Reforma Sanitária italiana está presente na formulação dos autores brasileiros, nos termos de Berlinguer,:

\begin{abstract}
Essa situação crítica pode inclusive demonstrar, talvez, que de fato a doença não pode ser considerada como um processo puramente biológico. As doenças, como marcos clínicos, mais ainda, sua difusão, sua transformação em fenômeno de massa e, portanto, em sua relação com a vida social, tem sua historicidade e mudam profundamente em cada período da história, são diversas segundo as épocas, as zonas do mundo, as classes sociais. São um dos espelhos mais fiéis do modo como o homem entra em relação com a natureza, da qual é uma parte, através do trabalho, da técnica, da cultura, ou seja, através das relações sociais mutáveis e das aquisições cientificas e historicamente progressivas ${ }^{47}$ (Berlinguer, 1972, p.8, tradução nossa)
\end{abstract}

No desenvolvimento de Conti, depreendemos a reflexão originária dessa produção teórica: o modo de vida no capitalismo como fator de adoecimento, considerando alimentação, aspectos emocionais, atividades físicas entre outros. A autora traça o paralelo da forma histórica capitalista com outras formas sociais em diferentes regiões e épocas, por exemplo, contrasta como os filhos urbanizados de pastores nômades da Somália apresentam condições de saúde distintas (piores) dos seus pais que viviam sob condições materiais mais restritas. Contudo, a sua prioridade analítica é frisar o caráter funcional da medicina ao capitalismo:

Sem dúvidas. Como nos comportamos? O que fazemos na realidade? Segundo minha opinião, nossa atuação e nossos conhecimentos biológicos

\footnotetext{
47 "Esta situación crítica puede incluso provenir, quizá, del hecho que la enfermedad no puede ya ser considerada como un processo puramente biológico. Las enfermedad, em los marcos clínicos y más todavía en su difusión, en su transformación en fenómeno de masa y, por tanto, en su interferir con la vida social, tienen sua historicidad, cambian profundamente en cada recodo de la historia, son diversas según las épocas, las zonas del mundo, las clases sociales. Son uno de los espejos más fieles del modo como el hombre entra en relación con la naturaleza, de la que es uma parte, a través del trabajo, la técnica, la cultura, o sea a través de relaciones sociales mutables y de adquisiciones científicas historicamente progressivas" (Berlinguer, 1972, p.8)
} 
se orientam pela conservação e ao aumento da competência em uma sociedade que precisamente se define por essa, e sobretudo, pela competência produtiva. Somente sobre tal tal base podemos nos definir (...)

(...) fabricamos infartos, eletrocardiógrafos para diagnosticar infartos e seções hospitalares para curá-los. Fabricamos câncer pulmonar e centros cirúrgicos para operá-los. Seria fácil, porém inútil diagnosticar que estamos loucos. Na realidade, nosso comportamento tem sua lógica: a lógica da competência. Criar um tipo de vida como menos stress e que reduzisse os casos de infarto, significaria diminuir a competência em nossa vida: por essa razão que não fazemos. Em troca, os afetados por infarto não supõe diminuir a competência e seus resultados. Quando um paciente de infarto está curado, reconhecemos sua capacidade de trabalho recuperada, somos o árbitro da luta de boxe: o pugilista caído se levanta antes de contarmos até dez. Quando, ao contrário, indicamos que nosso doente tem que solicitar a aposentadoria por invalidez, seguimos a lógica da competência, o mesmo árbitro que declara um nocaute técnico está inserido na lógica do boxe. Prevenir o infarto equivaleria a oposição a lógica da competência, e por isto o curamos. Não me refiro aos nossos "médicos", falo de todos os homens de nosso tempo e de nossa cultura. O mesmo poderíamos dizer do câncer de pulmão e sua prevenção significaria significaria intervir sobre a competência, eliminá-la, seja nas indústrias, seja nas automotivas, e por isso mesmo não tomamos precauções contra o câncer pulmonar. Porém, curar o câncer de pulmão significa reconhecer a competência sem nos opormos a ela: significa refrescar nosso campeão de boxe, desinfetar os cortes, passar a espojar sem extinguir o boxe: assim,curamos o câncer pulmonar com os prodígios da técnica. Não somos em absoluto os sacerdotes da vida, somos os sacerdotes da competência ${ }^{48}$. (Conti, 1972, p.296-297, traduação e grifos nossos).

48 "Sin embargo, ? como nos comportamos? que hacemos em realidade? Según mi opinión nuestra actuación y nuestros conocimentos biológicos se orientam a la conservácion y al aumento de la competência em una sociedade que precisamente se define por la competência, y sobre todo por la competência productiva. Sólo sobre esta base podemos definir (...)

"fabricamos infartos, electrocardiógrafos para diagnosticar infartos y secciones hospitalares para curar-los. Fabricamos cánceres pulmonares y quirofános para operários. Seria fácil, pero inútil diagnosticar que estamos locos. En realidade, nuestro comportamento tiene su lógica: la lógica de la competência.

Crear un tipo de vida con menos stress y que redujera los casos de infarto, significaria diminuir la competencia em nuestra vida: por esta razon que no lo hacemos. En cambio, curar los afectados por infarto no supone diminuir la competência de la vida, sino que significa reconocer esta competência y sus resultados. Cuando ante um paciente de infarto ya curado reconocemos su recuperada capacidade de trabajo, somos el árbitro del juego: el púgil derribado se levanta antes de contar hasta $\langle\langle$ diez $\rangle\rangle$. Cuando, por el contrario, indicamos a nuestro enfermo que tiene que solicitar el retiro por invalidez, seguimos en la lógica de la competência, lo mismo que el árbitro que declara un k.o técnico se halla dentro de la lógica del boxeo. Prevenir los infartos equivaldría a oponerse a la lógica de la competência, y por estol os curamos. No me refiero a nosotros <<médicos〉>, hablo de todos los hombres de nuestro tempo y de nuestra cultura. Lo mismo podríamos decir del câncer de pulmón su prevención significaria intervenir em la competência, eliminarla - ya sea en las industrias, ya sea em -, y por lo mismo no tomamos prevenciones contra el câncer pulmonar. Pero curar el câncer de pulmón significa reconocer la competencia sin oponermos a ella : significa refrescar a nuestro campeón de boxeo, desinfectarle los cortes o pasarle la esponja sin abolir el pugilato: así curamos los cánceres pulmonares com los prodígios de la técnica. No somos em absoluto los sacerdotes de la vida, somos los sacerdotes de la competência. 
Não obstante, a formulação do processo de determinação social do processo saúde e doença ser fundamental para medicina social ou saúde coletiva, existem vários aspectos oriundos do debate italiano incorporado pelos autores inaugurais, Arouca (2003) e Donnangelo (1975 e 1976), logo , a determinação social da doença não é objeto principal de suas teorizações, cabendo a formulação de Laurell (1983). Os autores abordaram aspectos fundamentais da relação social em saúde na década de 1970, discussão que transcende o objeto das disciplinas próprias da saúde ao analisar diversos elementos da realidade brasileira. No desenvolvimento do campo da saúde coletiva, a interdisciplinaridade na abordagem nos objetos socialmente construídos em saúde se manteve associada ao pluriparadigmatismo teórico e resultou, por um lado, na riqueza analítica nas abordagens de objetos, por outro, na incorrência de ecletismos de associações e utilização de termos de modo incoerente (Oliveira Filho, 1995).

No presente capítulo, a exposição está dividida em duas seções com o propósito de facilitar a compreensão do caminho analítico percorrido. Na primeira, abordamos o contexto social e histórico dos meios intelectuais predecessores dos autores "inaugurais" - Donnangelo e Arouca - e introduzimos panoramicamente as contribuições teóricas e "preparamos o terreno" para as hipóteses interpretativas ao demonstrar aproximação da teorização de Foucault aos autores marxistas na França e de apresentação dos debates realizados por intelectuais ligados ao Partido Comunista Italiano. $\mathrm{Na}$ mesma seção, apresentamos duas visões contrastantes sobre o caráter da modernidade produzida na saúde coletiva - Luz (2004) e Ayres (2001). Na segunda seção, desdobramos a hipótese analítica enfatizando os aspectos constituintes da teoria social em saúde e posteriormente frisa-se as associações realizadas na interpretação marxista sobre o trabalho em saúde de teorias críticas da modernidade, por exemplo, as intersecções dos conceitos foucaultianos e de noções gerais da teoria marxista; a ressignificação da epistemologia histórica de Canguillem e a influência indireta, porém, decisivas das teses Escola de Frankfurt sobre as relações sociais em saúde. Em que pese, as distinções epistemológicas e paradigmáticas, os elementos abordados são centrais para entendimento do caráter da modernidade das teorias sociais envolvidas e são fundamentais para o desenvolvimento da teoria social da saúde sobre os objetos contemporâneos. 


\subsection{A Teoria Social em Saúde nos Departamentos de Medicina Preventiva de São Paulo: As Relações dos Contextos Intelectuais entre Brasil, Itália e França.}

A consideração da inserção institucional dos autores nos auxiliam no entendimento de perspectivas e de pesquisa sem a pretensão de fundamentar a história intelectual da produção, característica da sociologia do conhecimento. A formação de cientista social de Donnangelo (Schraiber e Mota, 2015) e o amplo repertório das humanidades em Arouca, Mendes-Gonçalves e Schraiber, médicos de formação, significam que as produções não têm uma lógica empirista descritiva dos elementos em saúde, como se a pesquisa por si só revelasse a "verdade". As críticas à neutralidade da técnica na medicina (Conti, 1971) e ao exercício da validação científica como pretensão de universal (Canguillem, 2009) estão presentes na intepretação de tendências históricas do consumo, da ampliação dos serviços de saúde ou do trabalho médico no capitalismo. A partir de teoria social, não existe empirismo de influência positivista proponente do distanciamento imparcial da realidade estudada, dividindo o mundo social em duas esferas, daqueles produtores de conhecimento objetivo e a esfera do real onde não existem elementos de conhecimento objetivo.

Do mesmo modo, parafraseando Arouca, a teoria social em saúde tem "o berço de origem" nos departamentos acadêmicos ${ }^{49}$ da Medicina Preventiva, de fato, não há um muro intransponível entre o mundo que estudamos e os departamentos, somos inerentemente parte do mundo estudado, ainda mais, quando consideramos que a universidade não é neutra, mas campo de perspectivas teóricas e abordagens metodológicas, sistematizadas em programas que oferecem diferentes formas de interpretação (Burawoy, 2009). A apreciação da inserção objetiva evidencia em parte que o escopo de temas é condicionado a partir da lógica departamental das Faculdades de Medicina, ao mesmo tempo, o aprofundamento dessas temáticas extrapolou o paradigma biomédico e representa a fundação de um novo campo interdisciplinar. A relação social

\footnotetext{
49 “Opções teóricas e conceituais não são livres, mas conformadas em contextos de produção da ciência, pois as escolhas epistemológicas se definem segundo a posição de seus produtores na própria estrutura da prática científica enquanto trabalho social. Em síntese, a contextualização histórica do conhecimento impõe não apenas limitantes técnicos de operação, mas no sentido da vida social global delimita para o conhecimento científico quais as questões que são pertinentes. (Schraiber, 1993, p. 23)
} 
em saúde teve relevância nas Faculdades de Medicina e posteriormente se ampliou na saúde coletiva, enquanto as demais faculdades de áreas do conhecimento, tais como, a filosofia, as ciências sociais, a história, e a economia entre outras as relegaram a serem objetos da própria medicina e aos médicos revelando uma posição de desinteresse ou acrítica dessas relações.

O parâmetro teórico do enquadramento dos autores na linhagem da teoria marxista se sustenta no entendimento que esses desenvolveram pesquisa com instrumental teórico amplo, todavia, amparavam-se no marxismo na referência do materialismo histórico na totalidade social, em outros termos, as diversas influências encontravam-se na leitura marxista da relação social em saúde. A posição corrente situa a produção de Donnangelo como construtora de um campo de estudos, conforme termos de Pereira:

\footnotetext{
“(...) trata-se de uma obra que, a partir do estudo da prática médica em geral, busca a construção do objeto de campo de estudos que academicamente se denominaria sociologia da saúde, mas que em termos de materialismo histórico melhor se designaria por capitalismo e saúde ou saúde e capitalismo (Pereira, 1975, p.97)
}

A nosso ver, tal afirmação é parcial, as produções de Donnangelo e Arouca são pioneiras na produção teórica sobre a realidade brasileira, contudo, não necessariamente construíram a temática da sociologia em saúde ou do capitalismo em saúde. A interpretação de suas contribuições a partir da influência da produção teórica europeia, especificamente, dos estudos a respeito da prática médica articulada a estrutura social capitalista desenvolvidas nos contextos intelectuais italiano e francês permitem melhor apreensão das temáticas. Em termos gerais, nas abordagens da relação saúde e sociedade, tanto Donnangelo quanto Arouca criticam a racionalização moderna em saúde e estudam formas de organização da prática médica: comunitária e preventiva, respectivamente, ao aprofundarem a análise dos seus objetos de pesquisa, destacam articulação da prática médica com outras práticas na estrutura social, e seus ideários, elucidam que a medicina não é uma prática técnica autorreferenciada meramente, mas parte integrante da totalidade social. Compreende-se que a obra dos autores brasileiros representa uma continuidade dos debates dos meios intelectuais francês e italiano nos oferece o entendimento das associações paradigmática realizada pelos autores.

Indubitavelmente, a influência foucaultiana é o traço presente sobre toda a discussão acerca do corpo e da clínica oriunda do ambiente francês na década de 1960, 
porém, é a recepção marxista do autor na França que influencia fortemente os autores brasileiros, por exemplo, a tese do biopoder como tecnologia disciplinar não é assimilada inteiramente. Contudo, a distinção fundamental de realidades nacionais deve ser lembrada a produção teórica francesa analisava os serviços de saúde consolidados na racionalidade capitalista, enquanto Donnangelo e Arouca descrevem o processo presente na sociedade brasileira no século XX e suas particularidades.

O contexto da experiência do Maio de 1968 justifica a associação de ideários radicais com epistemologias distintas, Foucault e Marx, realizados por Polack (1972) e Boltansky (1979) ${ }^{50}$. O movimento de forte expressão estudantil, mas também associada aos movimentos operários, crítica radicalmente as formas convencionais, sobretudo vinculada às expressões culturais de modo de vida, sexualidade e ao corpo. No plano político, parte considerável da esquerda próxima da teoria marxista amplia as críticas às estruturas tradicionais do Partidos Comunistas oficiais, tendo na França uma forte expressão dessa forma tradicional e também ampliam a temática de debates e de crítica a teorias correntes do século $\mathrm{XX}^{51}$. As obras de Polack e Boltansky se aproximam da temática foucaultiana na historiografia, porém, não assimilam a prerrogativa de Foucault na priorização da crítica à construção discursiva de poder e seus sujeitos envolvidos ou submetidos a essa construção do que propriamente em outras relações sócio históricas.

A influência do ambiente intelectual italiano, foi ainda mais incisiva na produção de Arouca e Donnangelo. O debate em torno da reforma sanitária italiana, especificamente, as iniciativas de jornadas de estudos acerca das formações técnico científicas em saúde; relações medicina e a sociedade na década de 1960 e, particularmente, a atuação do instituto Gramsci ligado ao PCI (Partido Comunista Italiano) tinha por objetivo fomentar o estudo critico de temas como: a moral, família, as características do capitalismo contemporâneo. De acordo com Berlinguer (1972), nos círculos sociais caracterizados como "ambientes mais vivos da cultura italiana" existia

\footnotetext{
${ }^{50}$ No momento de publicação das obras centrais dos autores franceses, ambos tinham em torno de trinta anos.

${ }^{51}$ No Prefácio ao Anti Edipo no texto "Uma Introdução à Vida Não Fascista" publicado em 1972, Foucault aponta a obra de Gatarri e Deleuze como uma crítica avassaladora a três grandes vertentes: o marxismo na política e sociedade; a subjetividade a partir de Freud e ao estruturalismo referente à cultura. (Foucault,2000)
} 
efervescência teórico política nesse período. Dentro dos espaços do partido comunista, o balanço crítico do período estalinista associado às elaborações diversas desde o revisionismo que culminou nas teses do eurocomunismo até a tática radical do movimento operário através dos obreiristas e brigadistas. Tal pluralidade política são expressões do processo heterogêneo no qual as esquerdas desenvolviam novas formulações e analisavam outros objetos.

Embora Berlinguer (1972), assinale a insuficiência nas análises das ciências físico- naturais e das biológico-medicas nessas jornadas, define a coletânea de palestrasartigos realizada em $1968^{52}$ como primeiro passo nesse sentido e visava o combate as cristalizações doutrinárias do campo das ciências da natureza Para o autor, o plano de fundo de todas as contribuições é a articulação das estruturas sociais com a evolução histórica, científica e social da medicina ${ }^{53}$. A junção da evolução científica e da medicina é um tema central das obras do autor, o desenvolvimento científico como possibilidade de progresso no bem estar dos indivíduos (Fleury, 2015). É possível traçar um paralelo dos expoentes da produção marxista italiana e brasileira. A discussão crítica da técnica e da história tradicional da medicina aproxima Conti de Donnangelo e sua escola de pensamento - Mendes-Gonçalves e Schraiber. Distintamente, a dimensão política das reformas sanitárias, nas biografias e histórias parlamentares dos autores (Fleury, 2015) aproximam Berlinguer de Arouca, ambos defenderam que as possibilidades ofertadas pelo desenvolvimento científico da medicina com serviços através do Estados propiciariam melhores condições de vida.

\subsection{A Racionalidade Moderna em Debate na Saúde Coletiva}

A teoria social em saúde produzida no Brasil na década de 1970 se forja nas recepções dos contextos intelectuais franceses e italiano, nesses o movimento da sociedade e das ruas condicionam as ideias da academia. O preâmbulo dos contextos

\footnotetext{
52 Em 1969, a Itália vivenciou movimentos operários ostensivos através de greves e mobilizações conhecidas por como Outubro quente.

${ }^{53}$ Sobre o termo evolução utilizado por Berlinguer, observa-se o caráter incipiente do debate sobre caráter da ciência, contudo, várias contribuições presentes no livro "Medicina y Sociedad" refutam a concepção evolucionista da ciência e da história.
} 
intelectuais nos auxilia para precisar os pressupostos teóricos e paradigmas utilizados nas formulações. Objetivamos superar a menção recorrente da constituição da teoria social em saúde aos autores inaugurais para reflexão dos seus elementos constituintes.

Nessa perspectiva, indicamos que a teoria social em saúde ocorreu fundamentalmente com associações paradigmáticas de teoria críticas da modernidade. Sendo assim, os autores transitam nas temáticas centrais: do fenômeno moderno da medicalização, em três aspectos fundamentais, no investimento social do corpo na estrutura produtiva (Boltansky, 1979); na ampliação da clínica como espaço momento legitimando de diagnóstico e terapêutica sobretudo pela medicina (Foucault,1979) quanto de intervenção técnica sobre o corpo com o parâmetro de normalidade (Canguillem, 2009). Do mesmo modo na linhagem marxista, a constituição capitalista industrial, outro fenômeno central da modernidade, generaliza as mercadorias, inclusive, no âmbito do consumo de serviços privados de saúde e mesmo públicos no século XX (Polack, 1972 e Donnangelo, 1976), consequentemente, a própria força de trabalho dos profissionais médicos passam para a "mercadorização" através do assalariamento (Polack, 1972, Donnangelo, Mendes-Gonçalves, 2017 e Schraiber, 1993)

A partir desse entendimento, explicitamos que está presente nos autores clássicos e na constituição do campo da saúde coletiva uma teorização acerca da modernidade relacionada ao corpo e a relação histórica em saúde. Contraditoriamente, a reflexão sobre os elementos constituintes da racionalidade moderna ou dos parâmetros sócio-históricos da modernidade no âmbito da saúde e do corpo fundamentam o campo da saúde coletiva e, consonantemente, não são explícitos em sua produção teórica, salvo exceções.

Entre as produções teóricas do campo com abordagens diretas sobre a modernidade, desenvolveremos as realizadas por Luz (2004) e por Ayres (2001) tal paralelo demonstrará a pluralidade de abordagens no campo sobre o caráter da modernidade.

A contribuição de Foucault manifestada sobretudo nos temas: das formas de medicina social; a política sanitária no século XVIII e da constituição da clínica moderna (Foucault, 1977 e 2002) é inegavelmente a análise sobre a modernidade em saúde mais referenciada, em nosso entendimento, em que pese sua validade não pode servir como "encerramento" do assunto. 
Advogamos que três obras da década de 1940 são fundamentais para as associações teóricas pluriparadigmáticas nas décadas de 1960 e 1970, a mais conhecida e citada é a epistemologia histórica de Georges Canguillem (2009), especificamente, e $O$ Normal e o Patológico. Contudo, tão importante quanto e menos reconhecido é a influência das teses frankfurtianas, especialmente, presentes em Teses sobre o conceito da história (1987) de Walter Benjamim e a Dialética do Esclarecimento: Fragmentos Filosóficos (1995) de Theodor Adorno e Marx Horkheimer, sobretudo pela influência em Conti (1972) e Illich (1975) na discussão sobre o caráter social da técnica e diluídamente em toda discussão de racionalidade presente da medicina e nos serviços de saúde. Elucidamos quais aspectos presentes na obra que "permitiram" tal associação não estivesse fadada ao ecletismo, mas a produção teórica original.

\subsection{A Crítica a Racionalidade Científica e a Medicina no Brasil: Natural, Racional e Social}

Luz (2004) se dedica aos conceitos centrais; racional, natural, social, vida, saúde e doença presentes tanto na medicina quanto na sociologia, ou melhor, na conformação institucional da sociologia na França sob a influência de Comte e assinala os efeitos políticos da racionalidade cientifica como forma de intervenção na vida social. A ciência como forma social dominante do conhecimento sobre a vida não representou uma evolução ou mesmo progresso sobre as formas anteriores de conhecimento social, mas configura-se concretamente em "deslocamento" e "destruições" sobre formulações anteriores produzidas por outras relações sociais. Na concepção da autora, a consolidação do fragmentarismo, quantitativismo, materialismo entre outros ocorre associado ao ocultamento da dimensão da integralidade humana, ou seja, o conceito de homem é repartido em diversos aspectos.

A ciência opera separações e classificações do mundo, a razão como produtora de conhecimentos utilitários se utiliza dos princípios: a aplicação da mecânica; a prática da experimentação; a conformação sistemática do método; a intepretação matemática do mundo. De acordo com a autora, esses princípios são elementos basilares da racionalidade moderna e conformam as dualidades em saúde como como normalidade-patologia; equilíbrio-desvio; harmonia-perturbação; integridade-degenerescência são comuns à medicina e da sociologia de pressuposto positivista. A abordagem de Luz desvela que as concepções centrais são biossociais, na qual conformações sociais se mesclam à política e se manifestam nas instituições sociais. Desse modo, os conceitos natural, racional e 
social consagrados pela ciência moderna para a saúde não podem ser interpretados desprovidos das relações de poder.

A autora argumenta que a medicina é também uma disciplina do social, sobretudo pela produção do discurso do conceito de natural sobre a realidade social. Trata-se do arcabouço da racionalidade cientifica que "naturaliza" concepções construídas, todas as categorias centrais trabalham com o social, mesmo que possam corresponder aos aspectos fisiológicos ou biológicos No paralelo da medicina e da sociologia, o trânsito dos conceitos é nítido. Desse modo, Luz (2004) sob a influência de Canguillem expõe que a racionalidade científica fundamenta a normalização de sujeitos em ambas disciplinas, sendo uma característica inerente na constituição e reprodução de relações sociais de saúde e de doença.

Os pressupostos teóricos da autora são a interpretação weberiana da racionalidade associada a crítica de Foucault, sendo assim os sujeitos são submetidos às intervenções do saber médico por instituições sociais e médicas que funcionariam como dispositivos disciplinar da modernidade. Na obra, está presente a apreciação pessimista da racionalidade moderna sobretudo ao que tange ao exercício do poder disciplinar das instituições de saúde e educação; na normalização de indivíduos e de modos de condutas de vida. A racionalidade se impõe sobre a possibilidade de outras lógicas da vida social. A destituição da integralidade humana e suas relações vitais é o elemento de destaque, na qual a fragmentação do homem possibilita sua destituição para tornar-se o objeto de intervenção ${ }^{54}$.

Nessa perspectiva, o indivíduo como paciente, objeto de ordenação social, é associado à eminência do desvio da normalidade, converte-se a saúde como ausência de doença conformando o deslocamento da medicina como arte de curar indivíduos doentes para uma disciplina de doenças da medicina moderna, um "descaminho" da racionalidade moderna por sua própria lógica intrínseca.

Em contraposição às formas consagradas da medicalização e no propósito de restaurar a integridade humana através da concepção holística, Luz aponta as

\footnotetext{
54 “Esta compartimentação terá o efeito de 'negar' socialmente o sujeito humano e de 'neutralizá-lo' epistemologicamente, criando condições históricas para torná-lo, como a natureza, objeto de ciência, (...) coisa passível de intervenção, de transformação, de modelação, de produção” (Luz, 2004, p. 26)
} 
possibilidades do uso da homeopatia ou em seus termos, "vitalismo homeopático" inclusive, através de historiografia da luta da razão médica contra a homeopatia no Brasil. Luz, a partir da crítica focaultiana dos regimes de verdade, questiona a racionalidade moderna por alçar o conhecimento da ciência moderna ao estatuto "verdade" e por construir a fragmentação e destituição do homem. Sob o crivo da crítica, Augusto (1989) analisa que vislumbrar a homeopatia como o "outro" suprimido pela ciência tem debilidades. Na medida em que, a autora compartilha do pressuposto teórico no qual o conjunto das ações são correspondentes à secularização e a racionalização da conduta de $v i_{a}{ }^{55}$. A proposição e defesa de racionalidades alternativas, demonstra um "choque teórico" da relação entre do indivíduo e a racionalidade moderna (Weber, 2013) e a crítica foucaltiana da modernidade (Foucault, 1977 e 2003). A nosso ver, justamente pela autora refutar a perspectiva niilista (Luz, 2004) essa analisa as possibilidade alternativas, caminho parcialmente realizado pelo próprio Foucault. Desse modo, incorre no ecletismo de diagnóstico da secularização do conjunto da vida social ou "desencantamento do mundo" com proposições de ações que contrariassem a própria racionalidade para a fundação de nova racionalidade, porém, o diagnóstico weberiano assinala, embora o agente tenha escolhas, essas ocorrem dentro de parâmetro determinados pelo conjunto da sociabilidade sem espaços para a fundação de novas racionalidades

\subsection{Modernidade: Espaço Público e Epidemiologia}

Ayres (2001) aponta perspectiva distinta da apreciação de Luz e trata da emergência da modernidade a partir da interpretação de outro objeto sócio histórico: a constituição da higiene pública decorrida do programa da Ilustração e como elemento precedente da moderna epidemiologia e da ciência médica contemporânea. De acordo com o autor, as intervenções da higiene iluminista se constituiram no espaço público moderno na qual a pluralidade de posições políticas envolvidas nos processos de revoluções burguesas clássicas possibilitou tal surgimento. Nessa perspectiva, a medicina transita do conhecimento individual para a coletividade, consequentemente, seu objeto de estudo desloca-se para o "fato social" da higiene ${ }^{56}$. O sentido social e político do ideário

\footnotetext{
${ }^{55}$ Inclusive, Madel assinala “A partir do triunfo desta razão no final do século XVII, nenhuma teoria ou conceito pode mais fugir dos limites da morfologia do modelo científico, sob pena de ser considerada não científica, portanto, não verdadeira" (Madel, 2004,p. 123)

56 "Essa ampliação do objeto de apreensão e intervenção relativas à saúde para uma esfera que transcende o individual aplicando-se a conjunto de indivíduos ( à espécie no limite), vem elucidar a especificidade da
} 
do conjunto de intervenções técnicas balizadas pelo conhecimento científico em larga escala sob as condições de vida e de saúde da população é o epicentro da análise de Ayres.

O autor assinala que as reflexões acerca da dimensão coletiva da saúde e doença não são inauguradas na modernidade, ao contrário, visto o exemplo clássico da medicina hipocrática, porém, o caráter moderno altera totalmente o tipo de intervenção prevista na medicina grega. O médico na antiguidade grega se postava enquanto servidor da natureza, opostamente, na modernidade, a racionalidade científica é o fundamento da intervenção de fins práticos nas alterações e transformações e não de "mero acompanhamento" da natureza do indivíduo e do meio.

Amplamente, a doença vira tema "da dimensão social" e dos interesses nacionais e econômicos balizadas pela opinião pública seja no caso alemão ou no controle do escorbuto nos navios ingleses. Os exemplos dos períodos ilustram o caráter social e os interesses políticos sob tal dimensão, nos termos do autor:

\begin{abstract}
O plano objetivo em que se localiza a questão é coletivo - sua frequência e sua relevância prática - e se acredita poder reconstituir uma história objetiva da doença através da observação dos traços compartilhados pelos diversos doentes. Trata-se de uma verdadeira inversão por referência ao tratado de Hipócrates, que recomendava conhecer bem a physis para melhor compreender a história de cada caso.

Essa inversão não é inocentemente lógico-formal, apenas, mas tem um profundo significado histórico. Para nossos interesses, em particular, ela tem a enorme importância de anunciar, não só uma mudança de perspectiva epistemológica, mas também a configuração de uma nova objetividade que estamos tratando. Transcendendo o fato de a doença não ser mais deduzida de princípios gerais, essenciais, aplicados às situações particulares, mas ao contrário, ser apreendida indutivamente a partir dos casos particulares, a exterioridade lógica entre o caso e o conjunto dos casos inaugura como efeito, um novo espectro de legalidade, inédito até então nas ciências da saúde. Essa exterioridade é um eloquente sinal de emergência do espaço público como origem de necessidades práticas (Ayres, 2001, p.94, grifos nossos).
\end{abstract}

Nas reflexões a respeito da relação do espaço e a higiene pública, o autor apresenta a consolidação da esfera pública moderna por indivíduos privados e considera que o espaço público na sua constituição era mais plural e não necessariamente tinha a posição burguesa consolidada em relação aos demais grupos (Sennet, 1989). Nesse espaço plural, o surgimento da opinião pública influenciada pela racionalidade cientifica e, consequentemente, a emergência da esfera de objetividade propriamente sanitária forja-

saúde pública moderna como campo de objetividade (...) a ampliação normativa da saúde da saúde a partir da higiene e os determinantes das "feições" epidemiológicas..." (Ayres, 2001, p.86) 
se nos trabalhos científicos e nas ações da "saúde pública" no século XVIII ${ }^{57}$, o estabelecimento de "leis" e do comportamento populacional e entre outras intervenções técnicas. Tal movimento é anterior e presente na expressão da medicina do Estado alemã que por sua especificidade histórica, a racionalidade e a mentalidade sanitária foi desenvolvida pelo Estado através, principalmente, do diagnóstico populacional sanitário e da regulação estatal exercício da medicina.

Nos termos do autor, a higiene sócionaturalista como predecessora da conformação da epidemiologia moderna é sintetizada do seguinte modo:

Em síntese, a higiene socionaturalista representa a mais ambiciosa tentativa de descrição objetiva de um campo específico de normatividade da saúde que, uma vez configurado historicamente, determina dialeticamente uma profunda reestruturação da normatividade médica de um modo geral. Inaugura-se, então, um espectro mais amplo de "saberes e fazeres" em saúde, dando origem a uma nova ciência do campo da saúde: a epidemiologia (Ibid,p.98)

O desenvolvimento da higiene iluminista e das bases epidemiológicas são possíveis devido ao contexto político e social expresso no espaço público, o autor assinala:

\footnotetext{
O espaço público da saúde tem aqui sua especificidade ampliada e exaltada, com base em estudos que passam do caráter mais setorial e restrito para uma perspectiva universalizadora. Ao mesmo tempo, a higiene sistematizase e amadurece epistemologicamente, avançando rapidamente. Na direção da construção de um perfil científico nos moldes modernos. Nesse processo de amadurecimento, diversos aspectos concorrentes precisam ser considerados, como os notáveis progressos das ciências estatísticas, a ampla base social do pensamento reformista, o sanitário em particular, a formalização científica de outras disciplinas da área de saúde, tendo à frente a patologia experimental de Claude Bernard, a emergência das ciências sociais e, fundamentalmente a influência humanista e racionalista do iluminismo. (Ibid,p.97)
}

A emergência do espaço público moderno acompanha a constituição do capitalismo industrial na Europa Ocidental, essas tendências sócias históricas são concretizadas nas condições de vida e de saúde do proletariado urbano nas cidades. Essas se configuram em espaço sociais, políticos e sanitários explosivos, as contradições oriundas da revolução industrial e o pauperismo nos bairros operários fundamentam no campo da higiene e de estudos de outros campos correlacionam as condições de vida e de

57 “(...) a higiene conforma a primeira matriz racional para o avanço das ciências da saúde sobre o social” (Ayres, 2001, p.91) 
saúde. A partir da conceituação da pluralidade política do espaço moderno, o autor cita a formulação de Sigerist de uma higiene "desde baixo" representada por correntes reformistas e revolucionárias que associavam a realidade sanitárias às condições de vida, enquanto a representação política da burguesia através do Estado conformava a higiene “desde cima”. Em síntese, as perspectivas emancipadoras do programa do iluminismo estariam vinculadas à higiene "desde baixo"58.

A obra de Engels (2008) e Villermé (1988) são expressões das produções em saúde vindas "de baixo" relacionadas aos interesses dos trabalhadores. Inclusive, Villermé é expoente de uma ruptura do pensamento médico tanto nos preceitos prémodernos quanto nos modernos ao projetar a síntese dos diversos elementos analíticos nas condições gerais da vida do operário, logo, seu objeto é sobre a condição humana. Ayres comenta sobre a produção de Villermé, em seus termos.

\begin{abstract}
O propriamente humano passa a ser, assim, não só um ponto de partida, mas se coloca no núcleo do objeto a ser conhecido, como o destinatário de um conhecimento que só se completa quando a esse destino. Os elementos empíricos que a higiene de Villermé utiliza não tem qualquer significado positivo enquanto não são interpretados à luz de uma referência de vida digna. Não é a fábrica, a lã ou o tear que explicitam e explicam a doença e a saúde. São as formas de vida humana que permitem estabelecer uma mórbida identidade entre indivíduos tão diversos quanto trabalhadores das fiações de Lille e operário de uma manufatura londrina, por exemplo (Ibid, p.98)
\end{abstract}

Sendo assim, as experiências localizadas de saúde humana são entendidas como experiência humana em relações sociais e históricas, a objetividade especificamente social da saúde situa o humano em questão e não o funcionamento fisiológico individual na abordagem restrita.

Segundo Ayres (2001), o auge da mentalidade sanitária e a configuração da epidemiologia ocorre no período de transformação da esfera pública. A primeira passa de propositora da superação políticas dos problemas sanitários para o controle das influências patogênicas do meio para os organismos individuais (Ibid, p.99). Contraditoriamente, os fundamentos da higiene configuraram a epidemiologia, como ciência da dimensão social da experiência humana na coletividade de saúde e doença, porém, as alterações do espaço público e consolidação política da burguesia alça o espaço

\footnotetext{
${ }^{58}$ Nesse sentido, a França estabelece sua hegemonia no campo da higiene, inclusive, com a inserção dessa mentalidade sanitária social no curso de medicina na década de 1820.
} 
público como gestão coletiva dos interesses privados. A saúde é colonizada pelos interesses privados, ou concretamente, desenvolve-se como administração estatal das condições de vida e saúde, as relações de saúde desenvolvem a "indeterminação dos sujeitos sociais envolvidos" fundamentada no "paroxismo instrumental" da racionalidade científica (Ayres,2001). Consequentemente, o temário das análises se concentram na relação das causalidades do meio sobre as variáveis orgânicas individuais, desse modo, reduz se abordagem do entendimento humano sobre os problemas humanos, nessa perspectiva, segundo o autor.

É compreensível, nesse sentido, que uma teoria explicativa sobre a causa das doenças, tomada a partir da perspectiva de eficiência entre causa e efeito se tornasse não só possível, mas também a mais profícua alternativa para uma ciência da saúde. O causalismo mecanicista do experimentalismo bernardiano, sobre o qual se fundamente todo o edifício de saber da clínica moderna, transfere sua força também para o pólo da saúde pública, apoiado no acentuado desenvolvimento da estatística vital. (Ibid, p.100-101)

A combinação da demografia associada às variáveis morfo-funcionais orgânicas fundamentaram a lógica positivista presente na epidemiologia e também se consolidou na clínica contemporânea, embora os postulados e princípios da epidemiologia já estavam presentes na higiene pública, o paradigma do conhecimento em saúde implicava em proposições sociais de reforma social e não de reiteração social baseado no mecanicismo de base orgânica com empiro-indutivismo sobre o meio social.

Teoricamente, no processo histórico, as relações sociais de saúde moderna se desenvolvem em paralelo das contraditoriedades da própria modernidade. Ayres (2001), com base em Habermas (1984) enfatiza a cisão da esfera do sistema sobre o mundo da vida e da colonização do primeiro sobre o segundo, logicamente, assinala a colonização da razão técnica consolidada na moderna epidemiologia, no âmbito social geral representa a colonização tecnocrática do espaço público e sobre a intervenção do social na saúde. Contraditoriamente, estabelece-se que no auge da mentalidade sanitária embasada cientificamente ocorre a sua transformação pela redução ao caráter instrumental na mudança da esfera pública.

Em síntese, o espaço público resultante do processo histórico oriundo das ideias iluministas e das Revoluções Burguesas é colonizado pela racionalidade técnica instrumental de caráter privatista e conservador, logo, a epidemiologia contemporânea se distancia dos preceitos que a fundaram. Não obstante, a virada político social assinalada 
da transição da higiene para a epidemiologia, na discussão de Ayres, apresenta-se uma perspectiva progressiva da racionalidade cientifica em sua constituição na modernidade, grosso modo, a apreciação positiva da modernidade refere-se às possibilidades políticas e sociais de que a razão ofertaria potencial para a provisão de melhores condições de vida das massas urbanas no período histórico. A discussão de Ayres apresenta acordo com a historiografia de Foucault acerca da característica da intervenção da higiene ou da medicina social nos termos do autor francês sobre a dimensão coletiva e pública, contudo tem apreciação distinta do sentido da modernidade.

\subsection{Biopoder, Clinica e Mercantilização: A Recepção Marxista da}

\section{Historiografia de Foucault}

A influência decisiva de Canguillem ${ }^{59}$ sobre a obra de Foucault nas temáticas das ciências e nos conceitos de saúde e patologia é aspecto citado pelo próprio Foucault e demais autores. Todavia, esboçamos caminho distinto. Destacamos, primeiramente, as associações teóricas das teses marxistas à produção foucaultiana e posteriormente, interpretamos a teoria crítica de Foucault em relação à racionalidade médica.

Amplamente, a formulação de Foucault sobre as relações entre modernidade em saúde se expressam na constituição das formas de medicina social e da instituição da clínica na emergência da sociedade industrial e do capitalismo moderno ocidental. Nos termos de Foucault:

O que o século XVIII mostra, em todo o caso, são duas faces de um mesmo processo: o desenvolvimento de um mercado médico sob a forma de clientelas privadas, a extensão de uma rede de pessoal que oferece intervenções medicamente qualificadas, o aumento de uma demanda de cuidados por parte dos indivíduos e das famílias, a emergência de uma medicina clínica fortemente centrada no exame, no diagnóstico, na terapêutica individuais, a exaltação explicitamente moral e científica (secretamente econômica) do "colóquio singular", em suma, o surgimento progressivo da grande medicina do século XIX não pode ser dissociado da organização, na mesma época, de uma política da saúde e de uma consideração das doenças como problema político e econômico, que se coloca às coletividades e que elas devem tentar resolver ao nível de suas decisões de conjunto (Foucault, 2002, p.193-194)

\footnotetext{
${ }^{59}$ Posteriormente, destacamos a contribuição de Canguillem para o conjunto dos autores inaugurais da saúde coletiva.
} 
No prefácio em o Nascimento da Clínica (1977), ao introduzir a temática da mudança da medicina anterior para o seu caráter científico do século XVIII para XIX ${ }^{60}$, Foucault estabelece a medicina científica como característica da "nossa época", em outros termos, a modernidade. No desenvolvimento da obra, todo o repertório do objeto e métodos de intervenção do saber médico se manifestam na clínica como espaço legitimado social de diagnóstico e terapêutica, e sobretudo da vida e da morte.

Referente as formas de medicina social na historiografia foucaultiana, o poder político utilizou a medicina social justamente para socializar e controlar os corpos, a passagem do capitalismo da modernidade não institui uma transição da medicina coletiva para uma medicina privada, mas o seu contrário (Foucault, 2002, p.80). Desse modo, se estabelece uma "nosso-política" que não fora inventada no século XVIII, mas ela é sistematizada, socializada e tem como como pressuposto a tecnologia disciplinar em primeira instância sobre os corpos, no conceito de biopoder tem centralidade nessa reflexão e estaria inerente à constituição dos "aparelhos" da modernidade capitalista e suas instituições (hospital; hospícios; prisões; escolas).

A partir desse pressuposto ao discutir os exemplos históricos da medicina de Estado na Alemanha; da medicina social-urbana na França e da medicina industrial na Inglaterra. Foucault assinala: "Em primeiro lugar o Estado, em seguida a cidade e finalmente os pobres e trabalhadores foram objetos da medicalização.” (Ibid, p.93). A priorização do poder político da medicina social em um primeiro momento teve foco nos pauperizados, passando ao conjunto da população, sendo que a primazia nesse estágio não é meramente a existência dos corpos para o exército ou para a atividade produtiva, mas com uma dimensão maior do projeto de tecnologia de controle da população e dos corpos. Embora Foucault, não ignore o aspecto de reconstituição da força de trabalho, não coloca o aspecto como o central, sendo expressão prioritária somente na formulação da medicina social inglesa tornou-se a referência e prosseguiu porque articulou três elementos: "assistência médica ao pobre, controle de saúde da força de trabalho e esquadrinhamento geral da saúde pública” (Ibid p. 84).

60 "Entre o texto de Pomme que conduzia os velhos mitos da patologia nervosa à sua última forma e o de Bayle que descrevia, para uma época que ainda é a nossa, as lesões encefálicas da paralisiga geral, a diferença é ínfima e total” (Foucault, 1979, p.8). 
A respeito da recepção da historiografia focaultiana pelos autores inaugurais da saúde coletiva, Arouca e Donnangelo, advogamos que o advento histórico da medicalização nas formas da medicina social ou na legitimação da clínica no capitalismo ocorreram a partir da mediação dos marxistas franceses. Descrevemos algumas associações relevantes, o conceito foucaultiano do biopoder converte-se nas análises acerca do entendimento social do corpo na sociedade produtora de mercadorias (Boltanksy, 2004), a ressignificação do controle dos corpos parte de paradigma social distinto de Foucault, a prioridade analítica não está sobre a construção discursiva, mas na produção da vida material em sociedade, especificamente, na terminologia do "corpo investido socialmente". Os autores discutem a caracterização de Foucault em relação ao seu entendimento de que o investimento da sociedade capitalista no controle sobre os corpos é anterior a sua utilização enquanto força de trabalho, pois essa fora utilizada somente no século XIX na Inglaterra, sendo assim a preocupação não deve se restringir a capacidade produtiva dos indivíduos, mas ao poder disciplinar mais amplo. Sob esse prisma, a relação da reconstituição da força de trabalho para a produção tem centralidade no próprio fundamento da relação entre a modernidade e o corpo, o capital e o Estado se sobrepõem aos instrumentos disciplinares para os marxistas. Polack (1972) define a relação como "capital de corpos" (tradução nossa), pela capacidade única de criação de valor pela utilização da força de trabalho.

Do mesmo modo, a emergência da clínica de Foucault e a prática social balizada pela racionalidade científica integra a caracterização do movimento histórico de ascensão e declínio da clínica motivada centralmente pela transição do oficio liberal para o assalariamento das relações capitalistas no trabalho médico, tese central ${ }^{61}$ de Polack (1972) e com influência decisiva sobre Donnangelo e Arouca. Dito de outro modo, o processo de generalização da Clínica (Foucault, 2002) e posterior declínio (Polack, 1972) serve como pressuposto para o estudo das práticas de saúde para o capitalismo no final do século XX.

\footnotetext{
${ }^{61}$ Capítulo 1- O declínio da clinica - (tradução nossa) - Dechéance de la clinique
} 
Consideramos, em que pese, a leitura do Foucault a partir da mediação dos autores marxistas franceses ${ }^{62}$, as mediações estabelecidas, especificamente, com determinados textos de Foucault, também resultam em produção teórica original. Se por um lado, a influência de Foucault auxilia na ampliação de uma abordagem não economicista dos serviços de saúde ${ }^{63}$, por outro lado, os autores incorporam parcialmente suas contribuições. Tanto Donnangelo como Arouca $^{64}$ realizam uma operação seletiva na obra foucaultiana e buscam outras prioridades de análise para o entendimento da relação social em saúde. Contudo, a referência à historiografia foucaultiana é essencial, tendo a centralidade da clínica como aspecto crucial para o entendimento do conjunto das relações em saúde é aspecto incorporado.

Como vimos, a associação da historiografia e críticas discursivas foucaultianas e a crítica marxista, não é realizada pela somente linhagem marxista na saúde coletiva no Brasil. As produções no meio intelectual francês representam uma assimilação da produção focaultiana. Independente da riqueza de associações teóricas bem desenvolvidas ou a incorrência de ecletismos nas contribuições dos autores, destacamos uma diferenciação acerca da perspectiva filosófica do autor acerca dos objetos de sua análise e sua leitura da racionalidade moderna nesse processo, tal apreciação serve tanto para valorizar sua contribuição fundamental, mas também serve para apresentar outra chave de interpretação do desenvolvimento da relação moderna em saúde, caminho parcialmente desenvolvido pelo autores marxistas franceses e brasileiros.

Foucault ao discorrer acerca da racionalidade médica, descreve o impacto do significado de trazer a luz a observação empírica e aos atos técnicos. Esse autora explicita:

\footnotetext{
62 Nas obras consideradas do campo da medicina social ou saúde coletiva, a historiografia de Roberto Machado sobre a psiquiatria desenvolve percurso teórico mais alinhado à perspectiva foucaultiana.De maneira distinta da metodologia foucaultiana,

63 Como assinalado no texto específico sobre a produção de Arouca (2003), mesmo considerando a riqueza de suas associações, o autor tem passagens na qual incorre tanto no ecletismo quanto em outras no economicismo.

${ }^{64}$ No caso do autor, a influência de Foucault também se refere ao método de sua tese, Arouca realiza em seus termos uma "arqueologia materialista", em nosso entendimento, manifestação eclética entre a crítica do discurso de Foucault e marxismo estruturalista, ver seção "A Crítica a Medicina Preventiva: Legado de Arouca".
} 
As formas da racionalidade médica penetram na maravilhosa espessura da percepção, oferecendo, como face primeira da verdade, a tessitura das coisas, sua cor, suas manchas, sua dureza, sua aderência. O espaço da experiência parece identificar-se com o domínio do olhar atento, da vigilância empírica aberta apenas à evidencia dos conteúdos visíveis. O olho torna-se o depositário e a fonte da clareza; tem o poder de trazer à luz uma verdade que ele só recebe à medida que lhe deu a luz; abrindo-se, abre a verdade de uma primeira abertura: flexão que marca, a partir do mundo da clareza clássica, a passagem do «lluminismo» para o seculo XIX. (Foucault, 2008, p. 11, grifos nossos)

O sentido da empiria e a experimentação, elementos pressupostos, das técnicas médicas no manuseio e o desvelamento do corpo são centrais para a construção de um "regime de verdade" sustentado na dimensão da "nitidez" e "clareza" da ciência socialmente legitimada, no escopo do Iluminismo. A fundamentação da verdade estaria vinculada ao poder soberano do olhar empírico (Ibid, p.12). A preocupação do autor culmina como tal racionalidade médica constrói o indivíduo no plano discursivo:

(...) O olhar não é mais redutor, mas fundador do indivíduo em sua qualidade irredutível. E, assim, torna-se possível organizar em torno dele uma linguagem racional. O objeto do discurso também pode ser um sujeito, sem que as figuras da objetividade sejam por isso alteradas. Foi esta organização formal e em profundidade, mais do que o abandono das teorias e dos velhos sistemas, que criou a possibilidade de uma experiência clínica: ela levantou a velha proibição aristotélica; poder-se-á, finalmente pronunciar sobre o indivíduo um discurso da estrutura científica

$(\ldots)$

A experiência clínica - esta abertura, que é a primeira na história ocidental, do indivíduo concreto à linguagem da racionalidade, este acontecimento capital da relação do homem consigo mesmo e da linguagem com as coisas (Ibid, p. 13, grifos nossos)

Indubitavelmente, a magnitude da perspectiva de Foucault na crítica a racionalidade médica (scricto sensu) e científica (latu sensu) é aspecto ainda presente, principalmente, ao considerarmos o predomínio positivista do entendimento social do corpo e das práticas em saúde (Camargo, 1993 e 2007). Na abordagem historiográfica das problematizações, Foucault aborda instituições, condições sociais da emergência e legitimação de saberes, os discursos e, principalmente, as relações de poder na 
modernidade Ocidental ${ }^{65}$. Na perspectiva foucaultiana, não existiria relações, conhecimentos, sujeitos ou discursos supra históricos, as materializações desses objetos ocorreriam em contextos historicamente dados. Por conseguinte, mesmo o homem não é um objeto trans-histórico, em seus termos, é uma invenção do século XVIII, precisamente, ao se tornar sujeito do conhecimento e objeto do saber na conformação da modernidade ocidental (Foucault, 2007). No pensamento do autor, a não existência da natureza humana é o ponto de partida. Nitidamente, Foucault aborda as inaugurações da modernidade sobre a concepção de homem, dos instrumentos disciplinares e, posteriormente em sua obra, o controle societário sobre os corpos e sujeitos mais amplos, todavia, a permanência e transformação das características humanas está presente na reflexão foucaultiana no contraste dos períodos históricos através da reconstituição de arqueologia do saber e, em outro momento. da genealogia do poder, com o objetivo do conjunto da sua obra das problematizações do presente e a crítica nas formas históricas.

Dessa maneira, as obras de referência produzidas na década de 1960 em sua fase definida como arqueologia influencia o conjunto dos autores sobretudo da França e do Brasil. Consistia na história das relações contemporâneas a partir do trabalho de "escavação" e reconstrução dos caminhos dos discursos e das instituições na história, somente assim os regimes de produção de verdade poderiam ser elucidados. Foucault aborda a prática social vinculada a clínica e, porém, as questões postas não buscavam a objetividade ou validade prática da técnica e da ciência em suas intervenções, mas as construções discursivas. Sob o risco de simplificação, o objetivo de Foucault não é o fenômeno em si ou sua relação concreta, mas a construção discursiva sobre ele e por meio da reconstrução linguística, o caráter social do discurso, as relações de poder nas práticas sociais se desvelariam. Sendo assim, a linguagem racional da experiência clínica ocorre com base a partir da reorganização formal de vários elementos. Nesse sentido, a temática do intercâmbio homem e natureza não está presente, justamente, por esse aspecto a relação social do trabalho tão cara ao marxismo, não tem destaque na sua análise.

Contudo, a formulação do biopoder desenvolvida desde as formulações da medicina social no século XVIII (Foucault, 2002) até sua formulação consagrada em

\footnotetext{
${ }^{65}$ Em nossa apreciação, a contribuição de Foucault é uma crítica radical da modernidade, mas não se situa no campo da pós-modernidade. Para o debate acerca da posição de Foucault e a modernidade, ver Rouanet (1998) e Habermas (2000).
} 
Vigiar e Punir (Foucault, 1987) condensada na expressão "corpos doces e domesticados" onde os aparelhos disciplinares preparam os corpos para a dominação, incluso, mas não prioritariamente a atividade produtiva ${ }^{66}$ é temática fundante da saúde coletiva. Essa formulação sobre o corpo tem desenvolvimento nas obras do autor, em produções posteriores a década de 1970 altera seu percurso de análise, a título de exemplo, na obra o Nascimento da Biopolítica (2008) referente ao curso lecionado no Collège de France, a temática da medicina social ou mesmo da clínica são praticamente inexistentes, ampliase a biopolítica para as formais mais gerais e históricas da política, por exemplo, no estudo do neoliberalismo.

A título de contraste, em uma de suas últimas obras, no desenvolvimento da história dos processos de subjetivação em diversos períodos históricos, Foucault afirma realizar uma ontologia do presente ${ }^{67}$, na medida em que a investigação sobre as práticas de poder nas relações entre outros e pelo próprio sujeito e nas possibilidades de combate das formas estabelecidas do poder e de autoconstituição dos sujeitos (Foucault, 2010). A utilização da nomenclatura ontologia por Foucault é distinta da abordagem corrente dessa área do conhecimento na Filosofia, grosso modo, estudo ou definição das características inerentemente humanas desvinculado da história, principalmente, ao destacar o período presente. A abordagem de Foucault também é radicalmente distinta da concepção filosófica de Marx na ontologia histórica do homem como ser social na história e no intercâmbio com a natureza (Marx, 2011)

Distintamente da via crítica foucaultiana sobre a racionalidade na modernidade, percorremos o caminho da configuração da modernidade na história considerando

66 "É dócil um corpo que pode ser submetido, que pode ser utilizado, que pode ser transformado e aperfeiçoado" (Foucault, 1987)

67 "Mas existe, no interior da filosofia moderna e contemporânea, outro tipo de questão, outro modo de interrogação categórica: a que vemos nascer justamente na questão da Aujkliirung ou no texto sobre a Revolução [Kant]. Essa outra tradição crítica não coloca a questão das condições em que um conhecimento verdadeiro é possível, é uma tradição que coloca a questão de: o que é a atualidade? Qual é o campo atual das nossas experiências? Qual é o campo atual das experiências possíveis? Não se trata, nesse caso, de uma analítica da verdade. Tratar-se-ia do que poderíamos chamar de uma ontologia do presente, uma ontologia da atualidade, uma ontologia da modernidade, uma ontologia de nós mesmos. E me parece que a opção filosófica com a qual nos vemos confrontados atualmente é a seguinte. É preciso optar ou por uma filosofia crítica que se apresentará como uma filosofia analítica da verdade em geral, ou por um pensamento crítico que tomará a forma de uma ontologia de nós mesmos, de uma ontologia da atualidade. E é essa forma de filosofia que, de Hegel à Escola de Frankfurt, passando por Nietzsche, Max Weber, etc., fundou uma forma de reflexão à que, é claro, eu me vinculo na medida em que posso" (Foucault, 2010, p.21-22) 
elementos substantivos, tais como, o domínio racional da ação humana sobre a natureza e o corpo, e as contradições inerentes ao sucesso e fracasso humano dessa nova relação histórica forjada na modernidade.

\subsection{A Ressignificação da Filosofia Canguillem}

A nosso ver, a incorporação de Canguillem nos autores é o aspecto fundante da associação com as teses marxistas em saúde. A epistemologia histórica do autor desvelou a historicidade e a construção social das ciências vinculadas ao corpo e a vida, sua crítica permanece sendo a principal posição alternativa aos postulados do positivismo, sendo o Normal e o Patológico (2009) é obra de referência para a saúde coletiva. A crítica à racionalidade cientifica e a cientificidade, entendida como instrumentalização, tem como ponto de partida que toda construção científica é sócio-cultural. Logo, desnaturaliza ou dessacraliza a ciência, não sendo a forma social apriorística detentora do critério da verdade.

A associação das teses de Canguillem ao repertório marxista não ocorreu de forma harmoniosa desprovida de conflitos teóricos. No debate italiano, Laura Conti ao discutir o parâmetro da normatividade vital pela medicina que se balizaria como intervenção técnico científica para a restituição desse tipo específico de normalidade, exemplifica que uma "anormalidade" físiológica que não trouxessem prejuízos a condução de vida do indivíduo não seria objeto da medicina ${ }^{68}$ e recebe a crítica do histórico militante

\footnotetext{
68 "Diante do perigo de cair no erro de conceber a doença como anomalia e a medicina como técnica para converter o anômalo em normal, deve se definir o conceito de anomalia e reconhecer que cada cultura tem sua própria definição do que anômalo e prescreve um determinado ritual de comportamentos. No que consiste o conceito de anômalo em nossa cultura? No que consiste o ritual de comportamentos que assumimos na nossa cultura diante do anômalo.
}

Se poderia afirmar então que a nossa medicina é uma medida que se preocupa em restituir a normalidade as funções do organismo? Talvez sim. Porém, a normalidade não significa valor intermediário, valor comum ou provável etc. Não podemos definir a medicina como atividade ordenada a restituição da média comum de funções diversas desta média.

(...)

Consideramos como doença, toda anomalia particularmente significativa com uma consequência determinada: fazer a vida mais difícil como a do diabético, que deve procurar insulina e seringa para as 
comunista e antifascista, Massimiliano Aloisi que contesta a ideia do objeto do orgânico sendo conformado pela vida e cultura ${ }^{69}$. Explicitamente, a diferença de perspectivas poderia ser sintetizada à não ou a influência de Canguillem, inclusive, na interpretação de Aloisi, Conti manifestaria um "patriotismo de partido" ao destacar a relação histórica que a sociedade capitalista desenvolve e abordar exemplos de formas sociais com outras conformações culturais e históricas da relação saúde e doença em diversas sociedades não capitalistas. Na opinião de Aloisi, Conti superestimaria as formas culturais não capitalistas e criticava demasiadamente as sociedades capitalistas, se aproximando da visão de "bom selvagem" de Rousseau.

De forma retrospectiva, as produções marxistas embora analisaram em diversos momentos as condições de vida dos trabalhadores, sendo A situação da classe trabalhadora na Inglaterra de Engels (2008) a referência clássica, no conjunto do século XX, a temática do corpo, do entendimento de saúde ou mesmo da ciência foram aspectos relegados e sobrepostos por outras temáticas da filosofia ${ }^{70}$, economia e sociologia. Contudo, para além dos conflitos epistemológicos e teorias sociais distintas, o caráter das associações teóricas realizadas pelos marxistas sobre o Normal e o Patológico (2009) devem ser destacados.

Em prefácio da segunda edição da obra, Canguillem relata seus propósitos e os objetivos, em linhas gerais, esses são presentes em toda produção da saúde coletiva em maior ou menor medida, a reflexão crítica sobre os postulados científicos e as técnicas de intervenção sobre o homem (corpo e intelecto), especificamente, a medicina. Nos termos do autor tem-se que:

infecções. A anomalia que facilita a vida - como seria uma pessoa que não tivesse necessidade de vitamina C- não consideraremos como doença” (tradução nossa) (Conti, 1972, p.293-294)

69 “(...) não estou de acordo com a relativização da normalidade e da anomalia a partir de bases sociais. Aceitaria, seguindo pelo menos a tradição mais comum relacionar os conceitos de normal e anormal a partir de bases genéticas melhor do que as bases sociais, segundo os grupos étnico de raças, incluso, de espécies'(tradução nossa) (Aloisi, 1972, p.360)

${ }^{70}$ Inclusive nas formulações da Segunda Internacional, parte da intelectualidade aproximava o marxismo dos postulados do positivismo e do princípio ideológico do progresso e da evolução. Tal relação episódica ampara que autores como Santos (2010) enquadrarem equivocamente a teoria crítica marxista no amplo campo do positivismo, ignorando o conjunto da obra de Marx e de diversos marxistas. 
(...) algumas palavras de explicação a respeito de nossas intenções. Não é necessariamente para conhecer melhor as doenças mentais que um professor de filosofia pode se interessar pela medicina. Não é, também, necessariamente para praticar uma disciplina científica. Esperávamos da medicina justamente uma introdução a problemas humanos concretos. A medicina nos pareceria, e nos parece ainda, uma técnica ou arte situada na confluência de várias ciências, mais do que uma ciência propriamente dita. Parecia-nos que uma cultura médica direta viria favorecer uma colocação mais precisa e o esclarecimento de dois problemas que nos interessavam: o das relações entre ciências e técnicas e o das normas e do normal. Aplicando à medicina um espírito que gostaríamos de chamar "sem preconceitos", pareceu-nos que, apesar de tantos esforços louváveis para introduzir métodos de racionalização científica, o essencial dessa ciência ainda era a clínica e a terapêutica, isto é, uma técnica de instauração e de restauração do normal, que não pode ser inteiramente reduzida ao simples conhecimento. (Canguillem, 2009, p.10)

Canguillem ao abordar a temática específica do livro, destaca a não intencionalidade no julgamento ou proposição de alteração da medicina, pois as alterações caberiam aos próprios médicos, em seus dizeres:

O presente trabalho é, portanto, um esforço para integrar à especulação filosófica alguns dos métodos e das conquistas da medicina. É preciso dizer que não se trata de dar nenhuma lição, nem de fazer nenhum julgamento normativo sobre a atividade médica. Não temos a pretensão de querer renovar a medicina incorporando-lhe uma metafísica. Se a medicina deve ser renovada, cabe aos médicos a honra e o risco de fazê-lo. Tivemos, porém, a ambição de contribuir para a renovação de certos conceitos metodológicos, retificando sua compreensão pela influência de uma informação médica. Que não se espere, portanto, desta obra, mais do que quisermos dar (Ibid, p.10, grifos nossos)

Em nosso entendimento, a passagem acima é ilustrativa da distinção da obra do autor e das produções marxistas fundamentada em Canguillem, apontamos a diferença qualitativa das contribuições originais e a incorporação dessa corrente. Donnangelo (1976), Arouca (2003) e Mendes-Gonçalves (2017) transitam da epistemologia para a história, ou melhor da teoria do conhecimento para a teoria social em saúde e inserem as interpretações epistemológicas no centro da totalidade histórica. Essa associação eclética em determinadas passagens, possibilitou que a teoria marxista abordasse as relações entre a normatividade, saúde e o corpo dantes ignorados, para além da relação desses elementos com a produção da vida social.

O legado de Canguillem na saúde coletiva promove interessante debate. Ayres (2016) apresenta a epistemologia histórica francesa como aspecto fundamental tanto para autores clássicos quanto nas discussões contemporâneas de saúde. Não se pode olvidar 
os pontos de partida, por exemplo, a normatização da vida pela ciência e medicina, e a consequente, definição de patologia. Em suma, a impossibilidade da correspondência entre a ciência e a própria vida dos sujeitos. Os autores fundacionais da saúde coletiva incorporam a normatização da vida na discussão do poder na divisão social do trabalho, seja na relação entre médico e sociedade, no poder social da ciência, ou mesmo, na posição interna do médico no trabalho coletivo em saúde. Em síntese, os autores marxistas se amparam na epistemologia histórica dos conceitos da saúde e analisam a vida dos indivíduos em realidades das sociedades capitalistas concretas. Essa possibilidade é “ofertada" por Canguillem, pois o autor frisa a construção e a validação social na história da produção dos conhecimentos, os autores da saúde coletiva trabalham com o fundamento da sociabilidade na totalidade histórica.

De acordo com Coelho e Almeida (1999), a incorporação de Canguillem e de Foucault nos autores fundacionais da saúde coletiva se configuraria como uma "camuflagem" da teoria marxista em um cenário de repressão da ditadura, exemplificando, os aspectos repressivos em relação a defesa de tese de Arouca (Coelho e Almeida, 1999, p. 15), mas sobretudo, gerando uma identificação dos autores à epistemologia de esquerda em parte devido ao desconhecimento do conjunto da obra de Canguillem. Ayres (2016) contesta tal interpretação ressaltando que a incorporação do epistemológo francês é aspecto crucial no estabelecimento entre “ (...) o plano da política, dos movimentos sociais e dos serviços, de um lado, e da comunidade científica da medicina e da saúde pública, de outro." (Ayres, 2016, p.141), de acordo com Ayres, Canguillem oferta recursos efetivos para relacionar os componentes "interno" e "externo" nas ciências da saúde realizado pela saúde coletiva. Ayres comenta:

O tipo de aproximação crítica às ciências médicas e a certas concepções e práticas da saúde desenvolvidas por Canguilhem mostrou-se bastante interessante na perspectiva dos impulsos reconstrutivos que animavam a Saúde Coletiva desde as suas origens (Ayres, 2016, p.141)

Diferenciamos um aspecto da posição de Ayres, acerca da contribuição de Canguillem. Em O Normal e Patológico, não temos a crítica as práticas de saúde propriamente ditas, mas a dimensão intelectual da constituição científica. Desse modo, a crítica as práticas de saúde é o aspecto original dos autores fundacionais da saúde coletiva. Destacamos que a transição de estatutos da epistemologia de Canguillem para a teoria social no propósito de compreensão dos agentes envolvidos na relação de saúde é a 
principal injunção da constituição da saúde coletiva em relação a epistemologia presente em o Normal e o Patológico.

Nessa perspectiva, a influência de Canguillem ${ }^{71}$ tem múltiplas variações, conduz a constituição da crítica do discurso e do biopoder em Foucault; nos autores da saúde coletiva incorpora-se na teoria política marxista na sociedade de classes, logo a ciência se aproxima da ideologia seja da valorização da técnica ahistórica autoreferenciada (Conti, 1971) e Donnangelo (1976), seja na crítica ideológica à Medicina Preventiva em Arouca (2003). Polack (1972) e Donnangelo (1976) se fundamentam na crítica de Canguillem para expor que a medicina não se encerra em si mesma, quando a autora advoga que a medicina transforma objetos que estão fora de seu próprio estatuto e retomam Canguillem na proposição que não existe na fisiologia ou em qualquer dimensão biológica uma definição ontológica de doença e que a vida dos indivíduos que caracterizam os estados considerados normais ou patológicos.

A título do esforço interpretativo, assinalamos que a incorporação de Canguillem é distinta da perspectiva original do autor que realiza crítica "discursiva" dos termos da ciência médica. Em nossa visão, para os autores marxistas, Polack e Donnangelo e sua escola de pensamento destacam o caráter da ação do médico enquanto técnica de restauração do normal, porém, vinculada as tendências históricas do mercado de trabalho e do capitalismo. Do mesmo modo, a interpretação Conti sobre o caráter da técnica da medicina é fundamento precedente para a incorporação do próprio Canguillem na saúde coletiva, caracterizamos que as críticas de Conti e Canguillem ao positivismo se complementam na obra de Donnangelo, através da crítica a ideia e linearidade do progresso positivista.

71 “ (...) suprimam Canguilhem e vocês não compreenderão mais grande coisa de toda uma série de discussões que ocorreram entre os marxistas franceses; vocês não mais apreenderão o que há de específico em sociólogos como Bourdieu, Castel, Passeron, e que os marca tão intensamente no campo da sociologia; vocês negligenciarão todo um aspecto do trabalho teórico feito pelos psicanalistas, especialmente os lacanianos. Mais: em todo o debate de ideias que precedeu ou sucedeu o movimento de 1968, é fácil reencontrar o lugar daqueles que, direta ou indiretamente haviam sido formados por Canguilhem" (Foucault apud Ayres, 2016) 


\subsection{O Encontro da Crítica Marxista à Ideologia do Progresso com as teorias} críticas do corpo

Tornou-se comum o apontamento de comentadores que Donnangelo (1975 e 1976) e Arouca (2003) partiam da referência teórica marxista sob a leitura althusseriana ${ }^{72}$. A contribuição dos autores precisa ser contextualizada no ambiente intelectual do período no qual a interpretação de Althusser da obra de Marx era "hegemônica" em setores acadêmicos brasileiros. Essa localização tem importância, visto porque dela decorrem imprecisões acerca do marxismo na constituição do campo da saúde coletiva: grosso modo, a primeira: é a atribuição de uma concepção economicista ou estruturalista à produção teórica, na qual os indivíduos não teriam agência, papel na história e sendo estabelecida a supremacia do "econômico" sob todas as dimensões da vida social"73; a segunda imprecisão, a caracterização de que a contribuição fundacional da saúde seria balizada por uma aplicação de paradigma teórico limitado e ultrapassado, ocorrendo sua expiração de status de contribuição relevante e atual.

Tal qual a influência althusseriana, em nossa interpretação, os primeiros autores da saúde coletiva tinham influência indireta da crítica da modernidade capitalista de Marx. Esse fundamento analítico de uma teoria social serve para investigação sobre seus objetos e do, mesmo modo, possibilita as associações com outros constructos teóricos críticos da modernidade com pressupostos filosóficos distintos. Embora, os autores da interpretação marxista em saúde não abordassem diretamente as contradições da modernidade, trabalharam com questões correlacionadas, e tal tratamento apresenta desenvolvimentos significativos.

Em termos gerais, a modernidade é entendida como largo período de transformações históricas oriundo do declínio da ordem feudal e do desenvolvimento do comércio, e da constituição dos Estados nacionais entre os séculos XV e XVI. Adventos históricos constitutivos da modernidade, tais como: o Renascimento associado a revolução científica; a Reforma protestante; a expansão ultramarina e o mercantilismo.

\footnotetext{
${ }^{72}$ No apêndice de Saúde e Sociedade, Pereira aponta criticamente que Donnangelo poderia ter aprofundado a bibliografia dentro do "althusserianismo" ao invés da referência gramsciana em temáticas políticas e ideológicas.

${ }^{73}$ Para uma apreciação marxista crítica ao estruturalismo marxista ou "althusserianismo", ver (Lowy, 2002; Thompson, 1981)
} 
Na apreensão de Marx comumente destacada, esse processo permeado por elementos progressivos e contraditórios na história teve a ação político social da burguesia seu vetor. Essa classe revolucionária conduziu o processo histórico ao ponto de culminar nas Revoluções Burguesas com presença dos ideais da Ilustração e na Revolução Industrial no limiar do século XVIII. Para a dissolução dos antigos regimes, o desenvolvimento científico e econômico solapou os alicerces das formas tradicionais dos países capitalistas centrais. O diagnóstico do caráter revolucionário da burguesia em relação ao antigo regime e posteriormente sua dominação política e na conformação da vida social "a sua imagem e semelhança" tem na obra de Marx diversos desdobramentos.

Em nossa abordagem, frisamos como a consolidação da ordem burguesa e da modernidade transforma totalmente a relação com a natureza. Essa chave é fundamental para uma série de transformações produtivas e da própria vida social, inclusive, na relação com o corpo. O caráter histórico e político revolucionário da obra de Marx tem como pressuposto filosófico: a ontologia do metabolismo homem e natureza. No transcurso histórico da consolidação moderna, o conhecimento racional cientifico é legitimado como parâmetro para a interpretação tanto da natureza quanto da sociedade, em relação a primeira, pretende-se erradicar a visão animista sobre a natureza na vida e na atividade produtiva, o conhecimento da natureza serve ao controle, domínio e exploração, a ciência tem centralidade nesse processo de mudança social. A apreensão "objetiva" do mundo pelos sujeitos como forma dominante, ou seja, o entendimento de sua legalidade, estrutura e dinâmica independente dos arbítrios dos sujeitos. Nesse sentido, a filosofia se autonomiza em relação a teologia, o processo de secularização enfrenta o controle do modo de vida pelo clero e a dominação política burguesa é explicita e não se justifica mais pela tradição da nobreza.

Contudo, no âmbito da vida social, para além da cidadania burguesa e dos direitos formais, parte da perspectiva do programa sócio cultural da Ilustração projetava a organização da sociedade baseado no conhecimento racional, na qual as suas prerrogativas garantiriam a autonomia e liberdade individuais, bandeiras da Revolução Burguesa, sendo o liberalismo a expressão política e a concepção de indivíduo consolidada. As transformações produtivas integravam as apostas de que sociedades sem restrições materiais, no entendimento da época, possibilitariam indivíduos emancipados, visto o salto comparativo do modo de vida em relação ao regime feudal no contexto europeu. 
Distintamente dos anseios do programa da Ilustração, a consolidação do domínio político burguês no século XIX desenvolveu a dimensão instrumental da natureza com a produção capitalista e abandonou as consignas progressivas de caráter emancipatório clássicos de liberdade, igualdade e fraternidade. Em Marx, a existência da tensão do projeto político burguês e das perspectivas emancipatórias do projeto ilustrado são sinalizados com a repressão da burguesia associada a nobreza às demandas populares das revoltas denominadas "Primavera dos Povos", marco histórico da Europa ocidental, sendo o lançamento do Manifesto Comunista realizado no mesmo ano de 1848. A crítica de Marx explora a contradição da sociedade que atinge patamares produtivos de riqueza nunca dantes vistos combinada ao pauperismo do proletariado. A humanidade, contraditoriamente, alcança as possibilidades de melhora da vida para todos justamente na consolidação de uma forma violenta de dominação com igualdade formal

O debate sobre o caráter da razão na ciência moderna, estritamente, se a razão porta intrinsecamente o caráter conservador ou se a razão é instrumentalizada por demais relações societárias não está sob nossa alçada. Em Marx, a ordem do movimento do capital constitui a racionalidade burguesa manifesta na ciência moderna, sendo essa funcional ao capital, consequentemente, a subordinação da natureza e da dinâmica social ao capital é justificada sob os auspícios da razão, contudo, não substancializa a razão como protagonista da dominação, essa é vinculada às classe sociais sob dinâmica do valor que gera mais valor. Dito de outro modo, o conhecimento científico integra a dinâmica capitalista das mercadorias tanto na dimensão dos valores úteis à humanidade quanto em sua manifestação de valor na troca no ciclo de acumulação do capital. Dessa maneira, a contradição inerente da modernidade refere-se à centralidade da relação sócio histórica do capital e não a substancialização da razão. Nos termos da contradição de unidade dos contrários, o domínio humano da natureza originalmente progressivo e emancipatório para a produção da vida social permanecem mesmo que subjugados a forma histórica do capital pautada por aspectos regressivos.

O domínio do corpo é a expressão particular do domínio da natureza, sendo, a melhor expressão para esse caso, a terminologia de Marx: "a natureza humanizada". De forma análoga ao domínio e manipulação da água, o uso do vapor ou na força das correntezas do rio, o desenvolvimento cientifico e tecnológico que possibilitaram a capacidade de intervenção bem sucedida sobre a fisiologia e a mente. Contudo contraditoriamente, o potencial humanístico presente nesse processo é secundarizado e as ciências do corpo e 
da "vida", como as demais ciências compõe a relação social totalizante da acumulação e reprodução do capital.

Marx em sua obra demonstra como a pujança capitalista na produção e circulação de mercadoria altera a relação espaço-temporal: a expansão de mercados e de busca de matérias primas aceleram os fluxos através de meios marítimos e férreos e o relógio da produção marca o passo do andamento da vida. A crítica a ideologia do progresso como expressão da forma de dominação burguesa é componente do repertório de Marx, contudo, essa visão é associada dialeticamente que a modernidade capitalista também possibilita melhora nas condições de vida tanto no sentindo material do controle de recursos da natureza, quanto no âmbito da igualdade formal de direitos e do trabalho livre assalariado. Todavia, a denúncia do caráter da modernização capitalista e a desmistificação da apologia do desenvolvimento econômico como portador em si de consequências sociais progressivas previstas pelos economistas políticos clássicos é duramente criticada pelo autor.

De acordo com Lowy (2000), duas concepções dialéticas de progresso persistem em Marx, a primeira, em alguma medida, associaria o desenvolvimento das forças produtivas ao progresso na história como ciclo fechado, presente na reflexão acerca do acerca do colonialismo inglês na Índia. Não obstante, a destruição da tradição caminhar conjuntamente a com destruição capitalista das condições sociais dos indianos, com formas mais ultrajantes de exploração antes desconhecidas na sociedade tradicional. Nessa concepção, a natureza contraditória do progresso capitalista combina a barbárie e a "evolução" sobre as formas tradicionais de vida e de dominação, o desenvolvimento histórico ofertaria as condições de revolução social. Ainda segundo Lowy (2000), tal raciocínio é teológico com a "previsão" que com base na realidade material se possibilitaria o fim histórico da revolução e o socialismo como resultado do desenvolvimento das forças produtivas e de seus conflitos; é eurocêntrico no sentido de interpretar outras sociedades a partir do desenvolvimento capitalista europeu.

Entretanto, reduzir a posição de Marx a essa primeira concepção configura equívoco reducionista, na segunda concepção da dialética do progresso manifesta em $O$ Capital e nas cartas sobre a situação russa na década de 1880 (Lowy, 2000). O processo histórico é simultaneamente progresso e barbárie, o desenvolvimento das forças produtivas caminharia de mãos dadas com o custo humano. Nessa concepção, a 
lineariedade e a teleologia são descartadas e a história é vista como fluxo aberto sem prédeterminação. Nessa concepção, as transformações capitalistas e aspectos libertadores em relação à tradição atuam consonantemente com a barbárie, sendo simultaneamente o melhor e o pior da humanidade, o progresso capitalista carrega intrinsecamente o retrocesso humano ou calamidade social. Marx nos apresenta a seguinte ideia:

(...) Assim como na indústria urbana, na agricultura moderna o incremento da força produtiva e a maior mobilização do trabalho são obtidos por meio da devastação e do esgotamento da própria força de trabalho. E todo progresso da agricultura capitalista é um progresso na arte de saquear não só o trabalhador, mas também o solo, pois cada progresso alcançado no aumento da fertilidade do solo por certo período é ao mesmo tempo um progresso no esgotamento das fontes duradouras dessa fertilidade. Quanto mais um país, como os Estados Unidos da América do Norte, tem na grande indústria o ponto de partida de seu desenvolvimento, tanto mais rápido se mostra esse processo de destruição. Por isso, a produção capitalista só desenvolve a técnica e a combinação do processo de produção social na medida em que solapa os mananciais de toda a riqueza: a terra e o trabalhador (Marx, 2013,p.573-574)

Certamente, essas duas concepções de progresso se confrontaram ao decorrer do século XX, grosso modo, as posições evolucionistas permeadas pelo determinismo e do economicismo influenciadas pelos positivistas, politicamente manifesta tanto na social democracia alemã quanto no estalinismo encarnaram a defesa do progresso como desenvolvimento social. Diversos autores da tradição marxista romperam com a linearidade do progresso, as formas capitalistas não eram mais entendidas como somente um avanço, mas também uma regressão, em relação as formas pré-capitalistas. A expansão capitalista através do imperialismo e do progresso demonstra sobretudo brutal exploração, na qual a dominação implica em retrocessos humanitários. O processo histórico entendido como fluxo aberto sem determinações fundadas no nível de desenvolvimento das forças produtivas concebe teoricamente a prescindibilidade da barbárie capitalista para as transformações sociais. Nessa chave a disjuntiva política: socialismo ou barbárie se localiza, do mesmo que não existe patamar subjetivo mecanicamente condicionado pelo desenvolvimento capitalista e projetos de emancipação social ocorrem em realidades desiguais e combinadas.

A crítica da ideologia do progresso marxista encontra em Walter Benjamin seu maior expoente Lowy (2000). O autor defende a abolição da ideia de progresso no materialismo histórico, tal defesa não ignora as capacidades humanas expressas no conhecimento e nas técnicas, mas não são necessariamente progresso humano, ao contrário, na sociedade capitalista se desenvolve como progresso maléfico. O contexto 
europeu das duas guerras mundiais e das ascensões do nazi-fascismo influenciam decisivamente Benjamin e o conjunto dos autores de Frankfurt.

As reflexões na crítica à ideologia do progresso abarca a relação com a natureza, visto a envergadura inédita de sua destruição na história humana sob o movimento do capital, a revolução dessa forma seria um freio de emergência no trem da história em direção ao abismo. Nas teses sobre a história, Benjamin (1987), contudo, o conhecimento e o trabalho humano permanecem como aspectos emancipatórios, enquanto, a técnica, ciência e tecnologia na sociabilidade capitalista são retrocessos humanitários à medida que reiteram relações de poder.

Nas trilhas da teoria marxista crítica da modernidade, as contradições do intercâmbio homem e a natureza baliza a compreensão da ação humana sobre a natureza corpórea do próprio homem ${ }^{74}$. Embora, nas obras de Marx e do marxismo originário, a abordagem histórica do corpo ocorre envolto as demais relações sociais na história, sendo distante de ser temática prioritária, advogamos que a teoria marxista em saúde baseada na acepção crítica do progresso contrasta como os ideais emancipatórios da ilustração manifestado na ciência são secundarizados na relação sobre o corpo, sendo o caráter instrumental da relação de domínio sobre a natureza e da exploração de homens sobre homens ${ }^{75}$.

\footnotetext{
${ }^{74}$ As repercussões da problemática central da filosofia entre sujeito e objeto não será abordada, todavia, mencionamos que a discussão do corpo tem alterações significativas em relação à intervenção da natureza. Nosso desenvolvimento ampara-se na crítica de Hegel à Kant, dois pensadores centrais da modernidade, no sentido de superação do dualismo sujeito e objeto (Girotti, 2010).

75 "Sob a história conhecida da Europa corre, subterrânea, uma outra história. Ela consiste no destino dos instintos e paixões humanas recalcados e desfigurados pela civilização. $O$ fascismo atual., onde o que estava oculto aparece à luz do dia, revela também a história manifesta em sua conexão com esse lado nocturno que é ignorado tanto na legenda oficial dos Estados nacionais, quanto em sua crítica progressista. Essa espécie de mutilação afecta sobretudo a relação com o corpo (Korper). A divisão do trabalho, onde o desfrute foi para um lado e o trabalho para o outro, proscreveu a força bruta. Quanto menos os senhores podiam dispensar o trabalho dos outros, mais desprezível ele se tornava a seus olhos. Assim como o escravo, também o trabalho foi estigmatizado. O cristianismo louvou o trabalho, mas em compensação humilhou ainda mais a carne como fonte de todo mal (...)
}

A libertação do indivíduo europeu realizou-se em ligação com uma transformação geral da cultura, que aprofundava cada vez mais a divisão, à medida que diminuía a coerção física exercida de fora. $\mathrm{O}$ corpo explorado devia representar para os inferiores o que é mau e o espírito, para o qual os outros tinham o ócio necessário, devia representar o sumo bem. Esse processo possibilitou à Europa realizar suas mais sublimes criações culturais, mas o pressentimento do logro, que desde o início foi se propagando, reforçava ao mesmo 
As duas concepções marxistas dialéticas do progresso estão presentes nas formulações do contexto italiano da reforma sanitária e da saúde coletiva brasileira, sinteticamente, a primeira acepção partiria do diagnóstico que o desenvolvimento científico deveria ter seus resultados socializados para melhores condições de vida e de saúde (Berlinguer, 1972 e Arouca, 2003); a segunda aponta como a técnica e ciência para além da sua funcionalidade portam elementos regressivos (Conti, 1972 e Donnangelo, 1976). Destacamos o desenvolvimento da crítica a ideologia do progresso da segunda perspectiva.

\subsection{Teses Frankfurtianas: A Crítica ao Progresso e a Racionalidade Técnica Instrumental em Saúde}

A influência indireta das teses frankfurtianas aos autores da saúde coletiva na década de 1970 é a hipótese teórica da presente tese. A relevância do debate sobre o caráter do progresso e da técnica na sociabilidade capitalista realizado por autores marxistas no século XX fundamenta parcialmente a teoria social em saúde e a própria saúde coletiva. Sinteticamente, o paralelo realizado da crítica histórica da medicina de Conti (1972) e a crítica de medicalização como "iatrogênese social” (Illich, 1975) apresentam componentes oriundos da crítica ao progresso e à técnica produzidos por autores reconhecidos da Escola de Frankfurt. Não obstante, tanto a autora não cita

tempo, com o controle sobre o corpo, essa obscena maldade que é o amor-ódio pelo corpo, que permeia a mentalidade das massas ao longo dos séculos e que encontrou na linguagem de Lutero sua expressão autêntica. Na relação do indivíduo com o corpo, o seu e o de outrem, a irracionalidade e a injustiça da dominação reaparecem como crueldade, que está tão afastada de uma relação compreensiva e de uma reflexão feliz, quanto a dominação relativamente à liberdade. Nietzsche, em sua teoria da crueldade, e sobretudo Sade reconheceram a importância desse factor, e Freud interpretou-o psicologicamente em sua teoria do narcisismo e da pulsão de morte.

O amor-ódio pelo corpo impregna toda a cultura moderna. O corpo se vê de novo escarnecido e repelido como algo inferior e escravizado, e, ao mesmo tempo, desejado como o proibido, reificado, alienado. É só a cultura que conhece o corpo como coisa que se pode possuir; foi só nela que ele sedistinguiu do espírito, quinta-essência do poder e do comando, como objecto, coisa morta, "corpus". Com o auto-rebaixamento do homem ao corpus, a natureza se vinga do facto de que o homem a rebaixou a um objecto de dominação, de matéria bruta." (Adorno e Horkheimer, 1995, p.108-109) 
passagens de obras dos frankfurtianos ${ }^{76}$ quanto na elaboração de Illich (1975) as citações aos frankfurtianos sejam escassas.

A associações dos autores críticos das relações sociais em saúde e as contradições do Iluminismo desenvolvidas por Adorno e Horkheimer (1995) deve ser criteriosas, para os autores a influência dos grandes adventos históricos, as guerras mundiais, o nazifascismo são os aspectos definidores para diversos fragmentos filosóficos, embora tratem sobre o corpo no ocidente capitalista, não desenvolvem qualquer discussão sobre relações de saúde e doença. Não obstante, a teoria das contradições da modernidade não se encerra para períodos de "exceção" ou somente para as temáticas abordadas, ao contrário, suas formulações se direcionam para as relações sociais contemporâneas, como por exemplo, a presença indústria cultural massificadora e alienante, mas o cerne da contradição para o conjunto das relações sociais é abordada pelos autores do seguinte modo:

Não alimentamos dúvida nenhuma - e nisso reside nossa petitio principii de que a liberdade na sociedade é inseparável do pensamento esclarecedor. Contudo, acreditamos ter reconhecido com a mesma clareza que o próprio conceito desse pensamento, tanto quanto as formas históricas concretas, as instituições da sociedade com as quais está entrelaçado, contém o germe para a regressão que hoje tem lugar por toda parte. Se o esclarecimento não acolhe dentro de si a reflexão sobre esse elemento regressivo, ele está selando seu próprio destino. Abandonando a seus inimigos a reflexão sobre o elemento destrutivo do progresso, o pensamento cegamente pragmatizado perde seu carácter superador e, por isso, também sua relação com a verdade.

(...)

A naturalização dos homens hoje em dia não é dissociável do progresso social. $\mathrm{O}$ aumento da produtividade económica, que por um lado produz as condições para um mundo mais justo, confere por outro lado ao aparelho técnico e aos grupos sociais que o controlam uma superioridade imensa sobre o resto da população. O indivíduo vê-se completamente anulado em face dos poderes económicos. Ao mesmo tempo, estes elevam o poder da sociedade sobre a natureza a um nível jamais imaginado. ((grifos nossos, Adorno e Horkheimer, 1995, p.4-5, grifos nossos)

\subsubsection{A Critica à Ideologia do Progresso na História da Medicina de Laura Conti}

\footnotetext{
${ }^{76}$ Nos seminários italianos compilados no livro "Medicina e Sociedad" (1972), o formato praticamente não conta com citações de autores de referência.
} 
Em Estructura social y medicina, Conti (1972) a autora caracteriza a medicina, sobretudo, por uma técnica específica na sociedade capitalista, mas essa consideração é o preâmbulo para elucidar o seu caráter social e histórico. A autora tem como referência teórica o entendimento histórico da ação humana influenciada, sobretudo, por Gramsci, expressa nos objetos abordados relacionados ao trabalho e à história em sua maioria, influência presente também na discussão dos demais autores italianos das temáticas sociais da saúde. Contudo, Indubitavelmente, a autora estava inserida em um contexto acadêmico e político que as teses "frankfurtianas" circulavam consideravelmente.

Conti afirma que a medicina como aplicação técnica para a cura das enfermidades não esgota as questões da relação da medicina e o patrimônio dos conhecimentos da cultura e da ciência ${ }^{77}$, considerando sua dimensão sociocultural e a grande autonomia conquistada, a medicina não necessariamente é um conhecimento derivado da biologia.

Nitidamente, a partir da influência da concepção de história e a crítica da ideologia do progresso de Benjamin (1987), Conti (1972) refuta a concepção linear e triunfalista da historiografia apologética do progresso científico da medicina, logicamente, os avanços inerentes e progressivos do incremento técnico, cientifico e tecnológico da atividade médica estariam encadeados na narrativa de concepção positivista ou idealista. A autora aponta a dimensão ideológica que a história de medicina seria sintetizada pelo desenvolvimento técnico para atingir os objetivos gerais da cura contra a doença. Nos termos da autora tem-se que:

Porém, a história da medicina tal como tem sido escrito pelos positivistas (...) não é de grande utilidade. Não é grande utilidade porque se trata de uma história escrita do incremento tecnológico a margem de toda tentativa de historicidade. Na realidade se trata de uma cronologia, uma história escrita em termos da aprendizagem progressiva na qual a humanidade se utilizar dos meios mais idôneos para curar as doenças

Esse modo de escrever a história apresenta a história da medicina como uma aproximação progressiva em relação a verdade (...), atualmente possuímos e desenvolvemos diariamente: nessa via, a aproximação ocorreria por grandes períodos de êxtase e progressos hipocráticos fulminantes, talvez incluísse os

\footnotetext{
77، O materialista histórico os contempla com distanciamento. Pois todos os bens culturais que ele vê têm uma origem sobre a qual ele não pode refletir sem horror. Devem sua existência não somente ao esforço dos grandes gênios que os criaram, como à corvéia anônima dos seus contemporâneos. Nunca houve um monumento da cultura que não fosse também um monumento da barbárie. E, assim como a cultura não é isenta de barbárie, não o é, tampouco, o processo de transmissão da cultura. Por isso, na medida do possível, o materialista histórico se desvia dela. Considera sua tarefa escovar a história a contrapelo" (Benjamin, 1987, p.227)
} 
retrocessos, como no caminho da medicina grego-romana à medicina cristãmedieval, estas seriam a dificuldades de todo progresso até que consiga <tomar o caminho justo>, depois do qual o progresso premiaria e coroaria os esforços realizados pelo Homem ${ }^{78}$ (Tradução nossa) (Conti, 1972, p. 288).

A expressão do "retomar o caminho justo" desvela o entendimento da ideia do progresso como aspecto inerente à medicina. A interpretação dos conhecimentos técnicocientíficos da intervenção humana sobre o corpo e mente como parte componente do patrimônio cultural e da ciência nos fornece perspectivas analíticas de "longo alcance", ainda mais, ao considerarmos a chave de Benjamim "Nunca houve um monumento da cultura que não fosse também um monumento da barbárie"(Benjamim, 1997, p.227). Em que pese, não utilizar esses termos, a reflexão de Conti desenvolve a medicina nessa chave de interpretação, mesmo sem o pleno desenvolvimento das suas ideias, a contradição da medicina como patrimônio humano da cultura e da barbárie está no centro de sua análise. Nesse sentido, a discussão de Conti se vinculará de modo amplo à problematização da medicalização e sua racionalidade na sociedade contemporânea em Donnangelo (1976) e, sobretudo, na leitura social da medicina para além da dimensão técnico-científica e na posição de que o objeto da medicina se situa fora dela.

Conti (1972) apresenta como o postulado da competência, entendido como capacidade produtiva, pauta toda atividade médica nas relações sociais capitalistas os conhecimentos biomédicos estariam instrumentalmente a serviço dessa competência. Nesse sentido, a medicina também seria expressão da racionalidade instrumental e não como mera articulação desses conhecimentos com outras esferas da vida social na

\footnotetext{
78 "Pero la historia de la medicina tal como la han escrito los positivistas ( y si no me equivoco esta historia ha sido escrita, hasta el momento presente, por los positivistas), no es de gran utilidade (...) No es de gran utilidade porque se trata de una historia escrita al margen de todo intento de historicidad. En realiad se trata de una cronologia, de una historia escrita em términos de aprendizaje progressivo por parte de la humanidad de los medios más idóneos para curar las enfermidades o, en general, para la protección de la salud.(...) este modo de escribir la historia presenta la historia de la medicina como una aproximación progresiva a la verdade (...) que hoy poseemos y desarrollamos día tras día: en esta vía de aproximación se dariam largos períodos de éxtasis, progressos hipocráticos fulminantes, quizá incluso retrocesos, como el passo de la medicina greco-romana a la medicina Cristiano-medieval; éstas serían las dificuldades de todo progresso hasta que se consiga <<tomar el camino justo〉>, después de lo cual el progresso premia y corona los esfuerzos realizados por el hombre."
} 
dinâmica capitalista79. A concepção implícita da objetividade encerrada na "finalidade do procedimento" de forma ahistórica, localiza a historicidade nos meios para atingir determinados objetivos, enquanto aos objetivos gerais não existe historicidade. De acordo com a autora:

(...) a saúde se considera como um bem, cuja a definição é absoluta e não se modifica historicamente: como se tratasse de um bem ao qual o homem aspirasse sempre e desde sempre; por essa razão, a história da medicina se concebe, no senso comum, como uma conquista progressiva dos meios idôneos para conseguir aquele bem absoluto e ahistórico: tanto no senso comum como nos textos de história se adota implicitamente o conceito "objetivo", de finalidade do procedimento, e ao invés de uma historicidade substancial dos objetivos. A historicidade somente seria própria dos meios, mais ou menos adequados aos objetivos, que em geral tendem a ser adequados. Historicidade dos meios e ahistoricidade dos objetivos: essa é a concepção que subjaze a visão da cultura corrente tem da história da medicina. E em relação aos objetivos são ahistóricos, podemos afirmar que essa história teleológica falta o sentido da historicidade ${ }^{80}$. (Ibid, p.289, grifos nossos)

Na obra de Adorno e Horkheimer (1995), identificamos a centralidade dos meios e da técnica em si, com a demonstração do sentido da priorização da "operation", da valorização da eficácia do procedimento sobre a vida. Na formulação presente em a Dialética do Esclarecimento, no desenvolvimento da ciência moderna os homens renunciaram ao sentido, de acordo com os autores:

O que importa não é aquela satisfação que, para os homens, se chama "verdade", mas a "operation", o procedimento eficaz. Pois não é nos "discursos plausíveis, capazes de proporcionar deleite, de inspirar respeito ou de impressionar de uma maneira qualquer, nem em quaisquer argumentos verosímeis, mas em obrar e trabalhar e na descoberta de

${ }^{79}$ Contrastamos com a concepção da visão baseada no marxismo estruturalista althusseriano também presente nos autores inaugurais da saúde coletiva.

80 "la salud se considera como um bien cuya definición es absoluta y no se modifica historicamente: como si tratara de un bien al que hombre aspira siempre y desde siempre; por esta razón la historia de la medicina se concibe en la opinión común como una conquista progresiva de los médios idóneos para conseguir aquel bien absoluto y ahistórico: tanto en la opinión común como en los textos de história se adopta implicitamente el concepto <<objetivo〉>, de finalidade del procedimento, y a la vez uma historicidade substancial de los objetivos. La historicidade sólo seria propia de los medios, más o menos adecuados a los objetivos, que em general tienden a ser adequados. Historicidad de los medios y ahistoricidad de los objetivos: ésta es la concecpción que subyace a la visión que la cultura corriente tiene de la historia de la medicina. Y em cuanto los objetivos son ahistoricos, podemos afirma que a esta história teleológica le falta el sentido de la historicidade. (Ibid, p. p.289) 
particularidades antes desconhecidas, para melhor prover e auxiliar a vida", que reside "o verdadeiro objectivo e função da ciência".(....)

No trajecto para a ciência moderna, os homens renunciaram ao sentido e substituíram o conceito pela fórmula, a causa pela regra e pela probabilidade. A causa foi apenas o último conceito filosófico que serviu de padrão para a crítica científica, porque ela era, por assim dizer, dentre todas as ideias antigas, o único conceito que a ela ainda se apresentava, derradeira secularização do princípio criador. (Adorno e Horkheimer, 1995, p.5-6)

A vinculação da racionalidade científica e os procedimentos técnicos na medicina é desmistificado e combatido por Conti quando se contrasta a projeção de outra perspectiva política e ética do sentido de ação humana distinta em relação ao mundo, nos termos da autora essa reflexão levaria a "crise" da medicina praticada.

Por outra parte, desta crise de valores nascem novos. Nossa pseudoideologia orgulhosa entra em crise, posto que fazíamos crer que éramos os sacerdotes da vida: nos levava a crer orgulhosamente que a ciência que nós temos consagrado teria nascido do amor a vida e por obra desse amor, escondia a nossos olhos que esta ciência tinha nascido da competência da produção e pela competencia da produção. Porém, no ato ${ }^{81}$ precisamos nos dar conta desse fato, e no momento que tomamos consciência dele e talvez também vinculado à tomada de consciência, o mundo que nos rodeia já é outro e se afasta de nós: começamos a engendrar as condições para que se possa chegar a verdade até o presente momento não tem sido assim, para que se possa chegar a verdade na medicina, que nascida de uma coisa diversa e para uma coisa diversa se converta em defesa da vida, do amor pela vida e se situe a favor da vida. (Conti, 1972, p.309)

Na passagem acima, embora a autora tenha a leitura semelhante as considerações frankfurtianas tem sentido político distinto dos autores dessa escola e se aproxima da perspectiva político revolucionária de Gramsci na qual a formulação de proposições culturais seriam temas de luta nas sociedades contemporâneas, postura razoavelmente

\footnotetext{
81 "Por otra parte, de esta crisis de valores nacen nuevos. Nuestra pseudoideologia orgullosa entra en crisis puesto que nos hacía crer que éramos sacerdotes de la vida: nos llevaba a crer orgullosamente que la ciência a la que nos hemos consagrado había nacido del amor a la vida y por obra de este amor, ocultando nuestros ojos que esta ciencia há nacido de la competência en la producción y por la competência de la producción. Pero en el acto preciso en que nos damos cuenta de este hecho, en el momento en que tomamos consciência de ello y quizá también gracias a esta toma de conciência, el mundo que nos rodea ya es outro se aleja de nosotros: empezamos a engendrar las condiciones para que pueda llegar a ser verdade lo que hasta el momento presente no lo ha sido, para que pueda llegar a ser verdad que la medicina, nacida de una cosa diversa y para uma cosa diversa, se convierta em defensa de la vida, amor por la vida y se situe a favor de la vida. (Conti, 1972, p.309)
} 
diferente da proximidade da resignação ou pessimismo, o primeiro pela influência weberiana, o segundo característica da escola condicionada pelo período histórico vivido pelos frankfurtianos (Anderson, 1989).

2.8.2 A Teoria Crítica no Centro da Radicalidade Anti-Moderna nas Relações de Saúde de Illich

A compreensão da obra de Ivan Illich não se trata de algo simples, a dificuldade se concentra na intepretação das posições destacadas pela radicalidade, sendo inclusive caracterizadas como extremistas por seus críticos tanto no espectro da esquerda quanto da direita, para além da vastidão de sua obra que tratou de diversas relações contemporâneas: educação, ciência, economia e saúde, especificamente, o caráter da medicina moderna para os indivíduos. As críticas à medicina e a vida social na temática da saúde recebe especial tratamento nas análises de Nogueira $\left(2003^{\mathrm{a}}, 2003^{\mathrm{b}}\right)$ que de forma pormenorizada estuda as influências filosóficas do autor e destrincha o desenvolvimento de suas posições.

Sob o entendimento, que Illich é autor seminal para a teoria social em saúde, situamos sua obra no entendimento da modernidade ocidental, retomamos a interpretação compartilhada parcialmente por Nogueira (2003) que as teses frankfurtianas condicionam as críticas sociais à saúde w na influência/incorporação sobre os autores do início da saúde coletiva brasileira. Além de tal apreciação, em nosso entendimento, curiosamente, o debate sobre as contradições da Ilustração e da racionalidade instrumental se difundem nas considerações das relações sociais de saúde de Illich (1975), teses originárias dos frankfurtianos que não versaram sobre a temática. Não é preciso uma interpretação sistemática de toda obra de Illich para situar que a crítica à ideologia do progresso de Benjamim (1987) é elemento contínuo.

Primeiramente, as posições à contracorrente de Illich sobre diversas instituições sociais do século $\mathrm{XX}$ apontam que as relações sociais centrais constituídas na modernidade não cumprem suas intenções ou promessas: a escola não educa ao contrário torna-se em um instrumento conservador, por isso propõe: a desescolarização (Illich,1971); o desenvolvimento capitalista - econômico e cientifico- gera acúmulo e desperdício em relação à humanidade e ao ambiente e sua contraproposta de convivencialidade de "não desenvolvimento capitalista" (Illich,1973 e Gajardo, 2010). 
Acerca da medicina e dos serviços de saúde, sinteticamente, Illich diagnostica que a generalização dos serviços médicos produz um sistema não condizente com a saúde dos indivíduos. Os recursos orçamentários públicos ou o investimento capitalista privado em saúde não necessariamente melhoram as condições e qualidade da vida dos indivíduos e produzem maior sofrimento aos indivíduos nas diversas formas de iatrogênese, clínica e social. Assim sendo, a medicina não cura, ao contrário, é iatrogênica. Nos termos do autor:

A crença deste modo criada de que as pessoas não podem enfrentar a doença sem uma medicina moderna causa à sua saúde mais desgastes que os médicos que impõem seus serviços aos pacientes (Illich, 1975, p.37)

De acordo com Illich, somente o prolongamento da vida estaria concretizado na falsa ideia predominante de que a medicina moderna conseguiria atenuar as dores e o sofrimento no prolongamento da vida, a incidência de dor e sofrimento individual de outrora se mantém, mas o indivíduo enfrenta esses sob a ilusão de que as intervenções técnicas conteriam a "salvação", em suma, ocorre a formatação da experiência da vida pela medicina, em seus termos acerca da velhice:

Tomemos como exemplo a velhice. Na maioria das sociedades, ela é concebida como a condição das pessoas além de determinada idade e não como uma doença. Na nossa sociedade, essa condição foi medicalizada sem que aliás isso modifique a esperança de vida. Mais pessoas chegam a ela porque não morreram enquanto crianças, porém, uma vez chegadas aos 65 anos, não lhes restam mais dias para viver hoje do que no passado. Pouco importam a quantidade e qualidade das drogas que engolem, pouco importam os cuidados médicos que se lhes prodigalizem, os velhos morrem no mesmo ritmo que outrora. $O$ tratamento médico da velhice é geralmente uma cruel mistificação, que só funciona graças à credulidade do paciente. $O$ único aspecto maravilhoso da intervenção moderna nas desordens cardiovasculares, a artrose, a cirrose e o câncer dos velhos, é que os sublimes feitos dos biocratas e os sofrimentos que eles impõem não reduzem de muito a vida de seus pacientes. (Ibid, p.44, grifos nossos)

Do ponto de vista cultural, os indivíduos da modernidade perdem suas prerrogativas de decisão sobre seu corpo e a forma de viver, a medicina avança sobre o humano do ponto de vista orgânico e da condução da sua vida. Esse avanço tem sua máxima expressão em dois cenários, os indivíduos pacientes em tratamentos longevos vivenciam um "calvário" legitimado socialmente, ou seja, um castigo social sob os ditames da medicina e da ciência; e a atual sociedade tem uma relação com o fato natural da morte muito mais problemática do que outras sociedades de outros períodos históricos. Em diversas passagens, Ilich expõe como as formas tradicionais continham dinâmicas 
culturais que sanavam a questões humanas com maior sucesso em relação à modernidade, contrariando a visão simplista e evolucionista que a modernidade representaria um avanço para o conjunto da vida dos indivíduos em todas as esferas da vida.

De modo "voraz", aponta que a medicalização transforma a cultura e suprime a autonomia dos indivíduos, essa situação beneficiaria economicamente, simbolicamente e socialmente, a corporação médica, inclusive, a caracteriza como uma "sexocracia" por se tratar de instituição composta e na defesa de posições de homens que seriam validados como os guardiões da vida e da morte e a indústria capitalista com sua imensidão de mercadorias médicas. Sendo assim, a iatrogênese clinica e social são desdobramentos da medicina e dos objetivos econômicos da indústria, e também, homogeneizam culturalmente as sociedades a partir do ocidente, por essas razões, propunha a desprofisisonalização da medicina.

Consideramos que a vertente crítica da modernidade de Illich, trata-se mais precisamente de uma formulação teórica de caráter antimoderno ou uma concepção negativa de modernidade associada a crítica radical a ordem capitalista, logo, sua produção teórica e posições políticas não se mesclam com correntes políticas de caráter conservador contrárias à modernidade, se situam no espectro da esquerda. Sua crítica não se enquadra no debate da modernidade e pós modernidade elaboradas posteriormente e em outros meios intelectuais, embora a razão moderna tem em sua lógica inerente um aspecto humano regressivo na apreciação do autor.

Nogueira $\left(2003^{\mathrm{a}}\right)$ reflete sobre o caráter social da razão em Illich na definição da primeira crítica social à saúde, na qual denuncia os "exageros de uma razão que se autoimpulsiona" (Nogueira, 2003.p.31-32) no aperfeiçoamento contínuo de instrumentos de ações heterônomas em detrimento da autonomia dos indivíduos, por tal consideração, formula a proposição da sociedade convivencial na qual deveria existir a composição dos dois pólos de decisão, na qual um indivíduo não teria prerrogativa de submissão sobre outrém. Desse modo, apresenta a ideia da contraprodutividade formulada a partir dessa crítica à razão:

A chave para o entendimento da primeira crítica social da saúde encontrase no conceito de "contraprodutividade" (...) A idéia central da "contraprodutividade" é a de uma ferramenta que passa a produzir resultados paradoxais, operando contra o objetivo implícito em sua função. Constituem exemplos de contraprodutividade: o hospital que favorece a doença, o automóvel que produz trânsito lento, a escola que inibe talentos, 
entre outros. O mundo industrial gera constantemente tais frustrações no uso de ferramentas de utilidade social, porque faz com que estas operem de tal modo a minimizar ou paralisar a ação autônoma, indispensável para que as pessoas possam se beneficiar com conveniência e segurança de sua utilidade pressuposta. Algumas vezes, a contraprodução é resultante da sobreprodução, como no caso do engarrafamento no trânsito, demonstrando que essas ferramentas deixaram de agir como portadoras do progresso e do bem-estar. Outras vezes é o próprio açambarcamento da função (por um grupo profissional) que faz surgir o efeito paradoxal: a cura que não acontece porque o paciente espera que tudo seja feito pelo médico ou por sua equipe. (Nogueira, 2003a, p.31-32)

De acordo com Nogueira $\left(2003^{\mathrm{a}}\right)$ existem diferenças sobre a possibilidade de efetividade dos sistema de saúde as edições francesas e americana da obra Nemêsis, por isso advoga que à crítica de Illich na edição americana posterior busca conciliar com os resultados concretos da medicina em caso de regulação pública.

A respeito da relação social da técnica e da ciência e, especificamente, como tornam-se ditames na vida dos sujeitos. Nogueira expõe que a crítica da saúde de Illich se aproxima da crítica geral do Iluminismo de Adorno e Horkheimer (1995). Contudo, sua crítica à razão não é do mesmo tipo a realizada na formulação da racionalidade técnica instrumental e afirma que Illich se aproximaria mais de Marcuse sobre o homem unindimensional na sociedade industrial. Em nossa consideração, embora a crítica de Illich à razão não é do mesmo tipo a realizada pelos frankfurtianos na formulação da racionalidade técnica instrumental, essas se assemelhem. O próprio desenvolvimento da crítica social em saúde de Illich (1975) utiliza o expediente da crítica aos mitos modernos a semelhança de Adorno e Horkheimer (1995), na qual os retornos dos mitos se materializam nas ideias do progresso e da razão e conduziram a não emancipação. Illich também se apropria do pressuposto que a racionalidade inerente da técnica sobretudo seu caráter instrumental não é vinculado aos princípios éticos ou humanitários, ainda mais, assim como, o esclarecimento tem característica totalitária no sentido de abrangência da vida social, a homogeneização da relação de vida e morte na medicina ocidental também cumpre o mesmo sentido em Illich. A maior diferença da crítica social em saúde do autor em relação aos frankfurtianos refere-se ao entendimento negativo da razão em proximidade com os pressupostos filosóficos de Nietzsche, enquanto em Adorno e Horkheimer, a supremacia da razão da técnica é decorrência do progresso material e do domínio da natureza, porém, essas condições de possibilidades de caráter emancipatório humana são secundarizados pelos valores sociais de massa do capitalismo no século XX, 
vinculando a teoria crítica frankfurtiana à saúde, generalização do consumo dos serviços médicos e a própria medicalização da vida expressam esse processo.

Na teoria social em saúde produzida no Brasil, os autores não desenvolvem uma concepção negativa da modernidade próxima de Illich. Donnangelo não adere as suas teses, particularmente, a reprodução do modo industrial de produção e diferencia o uso do termo medicalização do conjunto de suas posições, se por um lado, valoriza o diagnóstico da extensão do cuidado médico aos indivíduos, polemiza diretamente acerca da ênfase unidirecional da reprodução do "modo industrial de produção" e "postura do marcadamente voluntarista pela desinstitucionalização da medicina" (Donnangelo, 1975, p.33) quando Illich propõe a desprofissionalização da medicina e cita o exemplo chinês (Illich, 1975).

Distintamente, Arouca (2003) é autor com maior influência das teses de Illich, embora cite a ideia central de Illich "como uma Nemesis (castigo) social em que o desenvolvimento social gera condições para a não-solução dos problemas que a própria sociedade cria." (Arouca, 2003, p.218) e compartilhe da constatação da "intromissão"o da ciência e avanço da medicina sobre a vida individual, as incorpora parcialmente de "modo marxista", por assim dizer, pois as entende como expressão da contradição: na qual os progressos científico-tecnológicos e da medicina não desenvolveram necessariamente melhores condições de vida e saúde, muitas vezes, ao contrário, essas possibilidades produzem desigualdades maiores. Essa aproximação também versa, implicitamente, acerca reificação da vida social, ou mais precisamente, da "coisificação" do homem, em Illich, a razão moderna diluída em várias formas sociais destitui o humano de sua condição, ao passo que na teoria marxista, o estranhamento do trabalho ao domínio capitalista das relações sociais manifesta na aparência da produção e circulação das mercadorias, produzem o domínio da "das coisas sobre o homem” que perde a condição humana (Marx, 2011). Enquanto em Illich, a medicalização é sobretudo a supressão da autonomia na medicalização da vida social ${ }^{82}$ o desenvolvimento da medicina moderna porta inerentemente o retrocesso humano, em Arouca a medicalização ocorre sobretudo pelo domínio de classes na sociabilidade capitalista e se baseia de forma genérica na

\footnotetext{
82 Teoria fundamental para as abordagens da fenomenologia antropológica da vivência de pacientes em tratamento.
} 
crítica da modernidade marxista na qual a luta de classes deve disputar os frutos do desenvolvimento humano, incluindo, a medicina enquanto patrimônio dessa ordem.

O Domínio Racional da Natureza e do Corpo: Interseções entre Canguillem e a Escola de FrankfurtPara além da constatação da associação pluriparadimáticas das teorias críticas da modernidade na teoria social em saúde. Assim como, a incorporação da crítica à ideologia do progresso e da técnica em relação as teorias sobre o corpo e da medicina na contemporaneidade. Interrogamos quais foram os alicerces das associações teóricas de paradigmas teóricos com epistemologias e objetos distintos tão distintos que resultassem em ricas interpretações analíticas. Desse modo, identificamos fundamentos filosóficos associativos possíveis de duas obras centrais: O Normal e o Patológico de Canguillem (2009) e a Dialética do Esclarecimento, Adorno e Horkheimer (1995). Nessa perpesctiva, abordamos a problemática acerca do domínio racional sobre a natureza na crítica filosófica das obras, tanto da intervenção normatizadora em Canguillem quanto do caráter instrumental da técnica (Adorno e Horkheimer, 1995). No propósito de síntese, destacamos o domínio humano da natureza como elementos compartilhado por ambas obras e, consequentemente, prioritário da análise da relação social moderna em saúde. Em nosso entendimento, esse fundamento em comum nas duas obras é decisivo para a riqueza dos autores "inaugurais" da saúde coletiva e da teoria marxista clássica sobre o trabalho em saúde.

Primeiramente, a despeito do caráter moral inerente ao utilitarismo ou mesmo a análise moral dos utilitaristas do século XVII e XVIII, ambas obras retomam Bacon (1999) enfatizando o sentido da filosofia e da ciência totalmente vinculada a resultados práticos defendido pelo autor. O retorno à Bacon e não ao conjunto dos predecessores e fundadores da ciência moderna e da consolidação do pensamento racional, não se refere somente aos postulados da experimentação, do método e da empiria como validação da investigação científica, ou mesmo, de seu caráter histórico decisivo nas ciências da natureza, trata se, sobretudo, demonstrar que o filósofo inglês é o defensor primordial da relação objetiva com a natureza que destrói o animismo e forja a separação com o mundo exterior natural na consciência humana e prenuncia.

Em termos gerais, a formulação conhecimento como poder de poder de Bacon, não obstante, seu caráter geral para o conjunto de relações sociais, refere-se centralmente no poder sobre a natureza, no sentido de intervenção, transformação, domínio e, 
especialmente, "luta" contra a natureza. O domínio racional sobre o corpo também se insere em dinâmica similar de domínio da natureza, seja na concepção mecânica ou na fisiológica da medicina (Canguillem, 2009), mesmo que para isso seja fundamental destituir o "humano daquele corpo".

Em Adorno e Horkheimer ao exporem o percurso filosófico da racionalização sobre a natureza, destacam Bacon como pioneiro, segundo os autores:

A filosofia buscou sempre, desde Bacon, uma definição moderna de substância e qualidade, de ação e paixão, do ser e da existência, mas a ciência já podia passar sem semelhantes categorias. Essas categorias tinham ficado para trás como idola theatri da antiga metafísica e já eram, em sua época, monumentos de entidades e potências de um passado préhistórico. Para este, a vida e a morte haviam se explicado e entrelaçado nos mitos. (Adorno e Horkheimer, 1995, p.6)

A interpretação dos diversos fenômenos naturais na forma de lei universais e o entendimento causal são fundamentos da ciência moderna e representam alteração significativa com a natureza. Essa reflexão segue em Canguillem, em especial, quando contrasta a concepção naturista à da medicina moderna, a primeira atribuiria a própria natureza os meios para a cura do homem, relegando pouco espaço para a intervenção humana na restauração do normal, essa concepção é insustentável para a medicina modernas, pois essa se baliza pelos princípios que homem pode "forçar e dobrar" a natureza conforme seus propósitos. Novamente, os preceitos de Bacon são marcantes no sentido de não obediência à natureza, mas sim o seu contrário. $\mathrm{O}$ aspecto mencionado é central como pressuposto na história conceitual de Canguillem sobre a medicina, nos termos do autor:

O pensamento dos médicos oscila, até hoje, entre essas duas representações (ontológica e dinamista-funcional) da doença, entre essas duas formas de otimismo, encontrando, de cada vez, para uma ou outra atitude, alguma boa razão em uma patogenia recentemente elucidada. As doenças de carência e todas as doenças infecciosas ou parasitárias fazem a teoria ontológica marcar um ponto; as perturbações endócrinas e todas as doenças marcadas pelo prefixo dis reafirmam a teoria dinamista ou funcional. Essas duas concepções têm, no entanto, um ponto em comum: encaram a doença, ou melhor, a experiência de estar doente, como uma situação polêmica, seja uma luta do organismo contra um ser estranho, seja uma luta interna de forças que se afrontam. A doença difere da saúde, o patológico, do normal, como uma qualidade difere de outra, quer pela presença ou ausência de um princípio definido, quer pela re-estruturação da totalidade orgânica. Essa heterogeneidade dos estados normal e patológico ainda é compreensível na concepção naturista que pouco espera da intervenção humana para a restauração do normal. A natureza encontraria os meios para a cura. 
Contudo, em uma concepção que admite e espera que o homem possa forçar a natureza e dobrá-la a seus desejos normativos, a alteração qualitativa que separa o normal do patológico era dificilmente sustentável. Desde Bacon, não se insiste na idéia de que só se pode dominar a natureza obedecendo-lhe? Dominar a doença é conhecer suas relações com o estado normal que o homem vivo deseja restaurar, já que ama a vida. Daí a necessidade teórica, mas com prazo técnico diferido, de fundar uma patologia científica ligando-a à fisiologia ...(Canguillem, 2009. P.11, grifos nossos)

Canguillem associa os desejos do homem pela manutenção da vida às teorias científicas como a fisiologia, e também, uma nosografia classificatória, em síntese, o melhor conhecimento das causas para a intervenção humana e sobretudo, o controle da doença como fenômeno natural. De acordo com suas palavras temos:

Essa evolução resultou na formação de uma teoria das relações entre o normal e o patológico, segundo a qual os fenômenos patológicos nos organismos vivos nada mais são do que variações quantitativas, para mais ou para menos, dos fenômenos fisiológicos correspondentes. Semanticamente, o patológico é designado a partir do normal, não tanto como a ou dis, mas como hiper ou hipo.

Essa teoria (das relações entre normal e patológico) não defende absolutamente a tese de que saúde e doença sejam opostos quantitativos, forças em luta, apesar de conservar a confiança tranqüilizadora que a teoria ontológica deposita na possibilidade de vencer tecnicamente o mal. A necessidade de restabelecer a continuidade, para melhor conhecer, a fim de melhor agir é tal que, levando-a às últimas conseqüências, o conceito de doença se desvaneceria. (Canguillem, 2009. P.13, grifos nossos)A interpretação das contraditoriedades da racionalização e do programa da Ilustração ${ }^{83}$ para os autores frankfurtianos assinalam sentido semelhante ao de "forçar e dobrar" a natureza elucidado por Canguillem, Adorno e Horkheimer atestam que a relação de conhecimento com a natureza é patriarcal em Bacon e o programa da ilustração utilizou tal posição de forma exponencial. De acordo com os autores temos:

\footnotetext{
83 (...)O programa do esclarecimento era o desencantamento do mundo. Sua meta era dissolver os mitos e substituir a imaginação pelo saber. Bacon, “o pai da filosofia experimental”, já reunira seus diferentes temas. Ele desprezava os adeptos da tradição, que "primeiro acreditam que os outros sabem o que eles não sabem; e depois que eles próprios sabem o que não sabem. Contudo, a credulidade, a aversão à dúvida, a temeridade no responder, o vangloriar-se com o saber, a timidez no contradizer, o agir por interesse, a preguiça nas investigações pessoais, o fetichismo verbal, o deter-se em conhecimentos parciais: isto e coisas semelhantes impediram um casamento feliz do entendimento humano com a natureza das coisas e o acasalaram, em vez disso, a conceitos vãos e experimentos erráticos; o fruto e a posteridade de tão gloriosa união pode-se facilmente imaginar ( Adorno e Horkheimer, 1995, p.04)
} 
A imprensa não passou de uma invenção grosseira; o canhão era uma invenção que já estava praticamente assegurada; a bússola já era, até certo ponto, conhecida. Mas que mudança essas três invenções produziram uma na ciência, a outra na guerra, a terceira nas finanças, no comércio e na navegação! E foi apenas por acaso, digo eu, que a gente tropeçou e caiu sobre elas. Portanto, a superioridade do homem está no saber, disso não há dúvida. Nele muitas coisas estão guardadas que os reis, com todos os seus tesouros, não podem comprar, sobre as quais sua vontade não impera, das quais seus espias e informantes nenhuma notícia trazem, e que provêm de países que seus navegantes e descobridores não podem alcançar. Hoje, apenas presumimos dominar a natureza, mas, de fato, estamos submetidos à sua necessidade; se contudo nos deixássemos guiar por ela na invenção, nós a comandaríamos na prática

Apesar de seu alheamento à matemática, Bacon capturou bem a mentalidade da ciência que se fez depois dele. $\mathbf{O}$ casamento feliz entre o entendimento humano e a natureza das coisas que ele tem em mente é patriarcal: o entendimento que vence a superstição deve imperar sobre a natureza desencantada. $O$ saber que é poder não conhece nenhuma barreira, nem na escravização da criatura, nem na complacência em face dos senhores do mundo. Do mesmo modo que está a serviço de todos os fins da economia burguesa na fábrica e no campo de batalha, assim também está à disposição dos empresários, não importa sua origem. Os reis não controlam a técnica mais diretamente do que os comerciantes: ela é tão democrática quanto o sistema económico com o qual se desenvolve. A técnica é a essência desse saber, que não visa conceitos e imagens, nem o prazer do discernimento, mas o método, a utilização do trabalho de outros, o capital. (Adorno e Horkheimer, 1995, p. 4 e 5, grifos nossos)

Por exemplo, Adorno e Hokheimer (1995) na análise do caráter da técnica do século XX e no balanço da ilustração remetem o entusiasmo de Bacon nas descobertas pragmáticas possibilitadas pela técnica nas descobertas da pólvora, bussola e imprensa que mudaram os aspectos das coisas em todo mundo. As teses de Adorno e Horkheimer (1995) demonstram como esse poder de intervenção sobre a natureza serviu consonantemente para o domínio do homem sobre outros homens, e a cisão homem e natureza foi pressuposto para a cisão da humanidade na modernidade pela racionalidade instrumental. O utilitarismo sem sentido ético teve viabilidade e se materializou enquanto racionalidade. De acordo com os autores tem-se que:

O que os homens querem aprender da natureza é como empregá-la para dominar completamente a ela e aos homens. Nada mais importa. Sem a menor consideração consigo mesmo, o esclarecimento eliminou com seu cautério o último resto de sua própria autoconsciência. Só o pensamento que se faz violência a si mesmo é suficientemente duro para destruir os mitos. Diante do actual triunfo da mentalidade fatual, até mesmo o credo nominalista de Bacon seria suspeito de metafísica e incorreria no veredicto de vacuidade que proferiu contra a escolástica. Poder e conhecimento são sinônimos. Para Bacon, como para Lutero, o estéril prazer que o conhecimento proporciona não passa de uma espécie de lascívia (Adorno e Horkheimer, 1995, p. 8, grifos nossos). 
A dinâmica incessante da complexificação da técnica e sua centralidade na sociabilidade capitalista forja uma realidade que as projeções de Bacon do conhecimento como forma de poder sobre a natureza não alcançaram, sendo que qualquer reflexão sobre o processo é vista como um atraso, pois não existe espaço sobre a reflexão humanitária inerente ao processo da racionalidade técnica instrumental. Conforme os autores tem-se que:

\begin{abstract}
O que não se submete ao critério da calculabilidade e da utilidade torna-se suspeito para o esclarecimento. A partir do momento em que ele pode se desenvolver sem a interferência da coerção externa, nada mais pode segurá-lo. Passa-se então com as suas ideias acerca do direito humano o mesmo que se passou com os universais mais antigos. Cada resistência espiritual que ele encontra serve apenas para aumentar sua força. Isso se deve ao fato de que o esclarecimento ainda se reconhece a si mesmo nos próprios mitos.
\end{abstract}

Quaisquer que sejam os mitos de que possa se valer a resistência, o simples fato de que eles se tornam argumentos por uma tal oposição significa que eles adotam o princípio da racionalidade corrosiva da qual acusam o esclarecimento. O esclarecimento é totalitário. (Ibid, p. 8)

Afinal de contas, qual a associação do domínio da natureza e, consequentemente, da técnica instrumental na sociabilidade para a problemáticas e objetos sociais em saúde ou propriamente na influência na teoria social presente na saúde coletiva. Em nosso entendimento, as relações sociais denominadas como medicalização são elementos tanto do "desencantamento do mundo" (Weber, 2013), sendo o esclarecimento entendido, inclusive, sua característica totalitária. Dito de outro modo, o indivíduo se insere em uma relação social histórica que compreende o conjunto das relações sociais de saúde pautada pela racionalidade, na qual as suas alternativas são limitadas ao conjunto das relações com sentidos definidos nesses parâmetros.

$\mathrm{O}$ aspecto diferencial da obra de Canguillem em relação as teses frankfurtianas que seu objeto não é sobre a racionalidade, mas sim a centralidade sobre a relação do desenvolvimento científicos e sua conformação sócio histórica sobre o corpo e sobre as definições de normal e patológico na medicina. Embora, o autor realize a história dos conceitos de forma minuciosa é com a utilização de recursos de cunho psicológico no processo de atribuições do normal e patológico que parece que o indivíduo chancela as definições da medicina. Para além da epistemologia empregada para apreender as questões envoltas no processo do normal e patológico. O homem com as definições tem 
a tranquilidade de que as técnicas possam resolver o mal ou a doença. Nos termos de Canguillem pode-se depreender:

(...)A convicção de poder restaurar cientificamente o normal é tal que acaba por anular o patológico. A doença deixa de ser objeto de angústia para o homem são, e torna-se objeto de estudo para o teórico da saúde. É no Patológico, com letra maiúscula, que se decifra o ensinamento da saúde, de certo modo assim como Platão procurava nas instituições do Estado o equivalente, ampliado e mais facilmente legível, das virtudes e vícios da alma individual.. (grifos nossos) (Canguillem, 2009. P.13)

Nesse sentido, a leitura das contribuições clássicas nos possibilitam entender dois pilares da relação contemporânea em saúde, ao mesmo tempo, que a humanidade deposita esperanças nas definições de normatização e sobretudo na técnica sua recuperação (Canguillem, 2009). Essas intervenções ocorrem sobre a dinâmica operativa da técnica instrumental por sua racionalização inerente não tem espaço para reflexão ou para consideração desse humano no processo (Adorno e Horkheimer, 1995). Em que pese todas as críticas fundamentais às iatrogênias (Illich,1975), seria socialmente inviável imaginar que a medicina e os conhecimentos biomédicos do conjunto das formações em saúde se manteriam na contemporaneidade se fossem meras ideologias autoreferenciadas, na qual os danos se manifestariam em relação às intervenções bem sucedidas na vida dos indivíduos. Dessa forma, negar os resultados práticos e o sucesso de intervenções ou mesmo minimizá-los, enfraquece potencial crítico da contradição. A questão é o quanto essa forma social com o mesmo de sucesso na redução do humano à condição anátomofisiológica do indivíduo e na sua vida, carrega os aspectos regressivos da racionalidade técnica instrumental manifesta também nas intervenções na saúde humana. 


\section{Capitulo 3: Balanço Crítico da Interpretação Marxista sobre o Trabalho em Saúde no Brasil}

Em Cadernos do Cárcere, Gramsci (2011) considera que o marxismo ou, em seus termos a filosofia da práxis, deve analisar a sua própria produção teórica nos termos do materialismo histórico, ou seja, a formulação teórica correspondia a quais condições objetivas e históricas? Qual era o propósito de intervenção da crítica sobre determinada realidade? Do mesmo modo, a autocrítica da teoria era necessária sobre suas lacunas e equívocos, sendo a apreensão do real "a prova de teste" da filosofia da práxis.

Na realidade brasileira, a luta por direitos sociais estabelece a saúde como um centro político na década de 1970, logo, o termo comumente utilizado do direito à saúde como reinvindicação é histórico. A luta das parcelas urbanas da população pela a universalização dos serviços em saúde integrou um conjunto de mobilizações presentes (Sader, 2001), o operariado, característico do fordismo periférico (Lipietz, 1989), expressava sua insatisfação nas pautas econômicas por meio do sindicalismo, todavia, ampliava seu questionamento para outras esferas sociais. Contraditoriamente, o desenvolvimento capitalista periférico que combinava industrialização e urbanização aceleradas a partir da década de 1930 precisava "compatibilizar" a assistência médica e de saúde a essas parcelas, ou melhor, viabilizar a reprodução ampliada do capital ${ }^{84}$.

O Estado nacional expressava sua natureza autocrática através do regime político da ditadura militar (Fernandes, 2008) e associado ao setor privado de assistência médica viabilizaram determinados serviços. Todavia, tal processo de oferta assistencial era inerentemente conflituoso, porque a formação social brasileira deveras desigual e o caráter peculiar da cidadania no país (Carvalho, 2002) exigiam lutas sociais das classes urbanas para a provisão dos serviços sociais. A historiografia destaca a luta dos movimentos sociais próximos aos espaços populares da igreja católica vinculados à teologia da libertação, na oposição política institucional através dos espaços ocupados

\footnotetext{
${ }^{84}$ Reprodução ampliada do capital, entendida como processo posterior à produção e circulação de mercadorias, considerando que a mais valia produzida e realizada apropriada como capital é reinvestida em maior volume para um novo ciclo produtivo, todavia, para viabilização desse maior aporte de capital, parte dessa mais valia precisa ser investida no conjunto social, pois é necessário possibilitar a recuperação da força de trabalho, para além do consumo regular dos assalariados (Marx, 2014)
} 
pelo MDB e suas prefeituras progressistas. Carvalho (2013) atribui especial destaque ao papel cumprido por determinadas gestões municipais, justamente pelo contato direto com as necessidades da população e na priorização da atenção primária. Ainda do ponto de vista político, a influência da luta clandestina das organizações de esquerda pelo fim da ditadura também é aspecto influenciador da produção teórica e da resultante do saldo político das forças que lutaram pela redemocratização colocassem o direito à saúde como um centro político de seus programas.

No âmbito acadêmico, as faculdades de medicina realizaram movimentos de contato com a realidade social através de projetos de integração docente assistencial e os departamentos de higiene se transformaram em departamentos de medicina social ou os departamentos de Medicina Preventiva ampliaram o seu escopo para a incorporação crítica da dimensão do social na saúde (Carvalho, 2013). Esse rico processo das décadas de 1960 e 1970, visto de forma retrospectiva indica a gestação do movimento da reforma sanitária da década posterior. Contraditoriamente, a luta por acesso e ampliação dos serviços também resultou na generalização da ordem biomédica através do fenômeno da medicalização. Assim como, esse processo é associado ao momento de constituição empresarial capitalista dos serviços, equipamentos e medicamentos sintetizados na expressão consagrada de Cordeiro (1980) da indústria da saúde no Brasil.

No presente capítulo, primeiramente, destacamos o desenvolvimento da temática central da intepretação marxista clássica referente à transição do assalariamento do trabalho e as reflexões acerca do trabalho coletivo e da complexificação das práticas em saúde. Posteriormente, vinculamos a análise da inserção no mercado de trabalho dos profissionais médicos às formas de organização geral do trabalho no capitalismo e na definição da proletarização peculiar. Criticamente identificamos que a centralidade analítica acerca do trabalho médico é chave para o entendimento das práticas em saúde e desvelou aspectos cruciais da dinâmica contemporânea. Todavia, também impôs limites de perspectivas em relação às demais categorias profissionais e na leitura do trabalho coletivo em saúde. Por fim, apontamos a pertinência dos fundamentos críticos desenvolvido pela linhagem na dinâmica contemporânea da relação de saúde e da organização do trabalho, sobretudo, acerca da interseção entre mercantilização e medicalização em um período de complexificação do trabalho social combinado. 


\subsection{Da Centralidade da Prática Médica à Teoria do Processo de Trabalho em}

Saúde: O Sentido Social da Complexidade

A construção social das práticas de saúde tem fundamentação nos processos históricos de medicalização, inclusa, a constituição moderna da profissão médica nos países capitalistas centrais da Europa nos séculos XVII e XIX. A medicina constituiu-se em trabalho social central para a vida social nesse processo e alcançou a legitimidade social de um trabalho de caráter técnico-científico embasado intelectualmente, diferenciando seus profissionais do conjunto dos trabalhadores reconhecidos como, por exemplo, o proletariado fabril, mas também, dos demais ofícios ou negócios inclusive aqueles próximos a dimensão da saúde humana como farmacêuticos ou dentistas ${ }^{85}$. Na ampliação da medicina como oficio liberal no século XIX, o centro da prática estava resguarda pela autonomia do profissional (Schraiber, 1993; Freidson, 2009)

Arouca (2003), Donnangelo (1976), Mendes-Gonçalves (1979) e Schraiber (1993) interpretam a prática médica na estrutura social capitalista e a fundamentam a partir da teoria social em saúde. Os seus objetos centrais de pesquisa remetiam às tendências contemporâneas: a ampliação da clínica, entendida como instituição legitimada de diagnóstico e terapêutica pela medicina; a generalização do consumo e a racionalização dos serviços no século XX, sendo a medicina comunitária expressão dessa relação sócio histórica em Donnangelo e a medicina preventiva em Arouca. Os autores contextualizaram como os serviços e a política estatal de saúde estavam condicionadas pela acumulação do capital e às pressões das classes sociais para sua provisão.

As práticas de saúde foram centralmente interpretadas na articulação com as demais práticas sociais, especificamente, na subordinação dos serviços de saúde à reconstituição da reprodução da força de trabalho é um ponto de partida, mas a produção

85 "Essa desproporção no valor dado ao ético e ao técnico igualmente se observa através da distinta conceituação formada em torno de intervenções tecnicamente próximas, cuja base em relação à outra: “(...) mesmo em 1878 o British Journal declarava ser a medicina uma profissão e a odontologia ('dentistry'), predominantemente, um negócio. (...) O farmacêutico continuou um simples comerciante mesmo depois de fundada em 1841 a Pharmaceutical Society, até que os Pharmacy Acts de 1851 e 1868 criaram pela primeira vez uma profissão de pessoas formadas e qualificadas e vedaram a venda de tóxicos por estranhos à mesma mesa. (...) Os óticos continuaram a ser homens de negócios até a década de 30" (Lewis, R. and Maud, apud Schraiber, 1993, p.152) 
dos autores não se encerra sob tal condição básica. Contudo, as obras se diferenciam no aspecto metodológico, Donnangelo (1975) identifica tal dimensão na pesquisa de campo a partir dos elementos concretos, a inserção do profissional médico no mercado de trabalho na região metropolitana de São Paulo, no tempo em que, Arouca (2003) faz o caminho inverso, alcança o trabalho médico a partir das relações gerais : a crítica geral do ideário da medicina preventiva e da formação social capitalista, à maneira ensaísta utilizando-se de ampla bibliografia. Essa observação não implica que a tese de Arouca era desprovida de elementos empíricos, mas ao recurso metodológico da elaboração teórica. Referente à atividade laboral propriamente dita, os autores se concentraram na principal figura do processo contemporâneo da medicalização e da generalização da clínica pelo Estado (Foucault, 2002): o médico.

Nesse âmbito, Donnangelo funda uma escola de pensamento denominada teoria do processo de trabalho em saúde (Mendes-Gonçalves, 1994). Os autores dessa concepção pautaram a construção dos seus objetos de pesquisa alicerçados na concepção social acerca da técnica e da ciência, isto é, o predomínio técnico não poderia ser visto como elemento neutro desassociado das formas sociais e históricas, pressupostos de Conti (1972). Inquestionavelmente, a compreensão crítica sobre a prática médica a partir dos elementos constitutivos de trabalho na sociedade capitalista possibilitou a interpretação da historicidade e a crítica ao tecnicismo e à ideologia. Cabe o destaque que Donnangelo não analisou o processo de trabalho médico como objeto de pesquisa. Na realidade ela desvelou como a prática médica não poderia ser vista como uma atividade técnicocientífica neutra, ou melhor, que essa prática deveria ser vista enquanto trabalho, sendo a localização do objeto da medicina externo a ela, pois as transformações sobre o corpo ou meio físico eram socialmente determinadas (Donnangelo e Pereira, 1976).

Desse modo, para análise da atividade do profissional caberia instrumental analítico distinto da conformação biomédica, baseada na redução anátomo-fisiológica sobre o corpo e prescritora de técnicas. A constatação crítica do caráter social da técnica prática médica na estrutura social capitalista e, logicamente, dos demais profissionais de saúde é crucial. Polack (1972) e Donnangelo (1976) diagnosticam que a dimensão técnica marca tanto a ascensão da clínica quanto o seu posterior declínio como meio de trabalho 
liberal sob bases do desenvolvimento capitalista no setor ${ }^{86}$. Ademais, a combinação da medicina privada focada na clientela livre e a medicina socializada financiada pelo Estado em alguma medida também se mantém. Contudo, as transformações técnico-científicas na relação social do capital alteram o exercício autônomo da abordagem individual do profissional, supera-se à "imediatez na relação entre o trabalhador e os instrumentos de trabalho" (Donnangelo, 1976, p. 18), e aumenta-se a complexidade.

Esse processo transforma a inserção do médico nos serviços de saúde e culmina no processo de especialização e heterogeneidade ocupacional. Essa heterogeneidade de inserção no mercado de trabalho apresenta a tendência da ampliação do assalariamento sobre as formas liberais "clássicas" da clínica nos moldes originários. Para a autora, esse resultado tem as transformações explicadas a partir da base técnica e científica do setor de produção dos serviços em saúde no capitalismo da segunda metade do século XX, com aumento da complexificação e da especialização das ocupações.

A contribuição de Schraiber (1993) pode ser caracterizada como um ponto de chegada das reflexões acerca da transição do trabalho e das transformações da medicina de seu caráter predominantemente liberal autônomo para o assalariamento empresarial e estatal, e sobretudo, pela incorporação de tecnologias materiais e a progressiva especialização da profissão prenunciada anteriormente. $\mathrm{Na}$ análise da autora, a tendência histórica de destituição do exercício liberal da medicina para a organização capitalista dos serviços é caracterizada como transição da medicina liberal à medicina tecnológica. A ampliação analítica sobre diversos aspectos de trabalho e de modo de vida nesse processo histórico para além da inserção do médico no mercado de trabalho e da propriedade dos meios é o aspecto diferencial de sua obra em relação aos seus predecessores.

Do ponto de vista teórico, a autora incorpora e aprofunda as contribuições de Freidson (2009) ${ }^{87}$ na abordagem do trabalho médico, estritamente, sobre a construção da autonomia profissional dos médicos e as insere no entendimento marxista sobre o trabalho

\footnotetext{
${ }^{86}$ Contudo, os aspectos originários da constituição moderna da clínica se acentuam com a prática do diagnóstico e terapêutica incrementada cientificamente na contemporaneidade, assim como, o entendimento comum dos indivíduos de que os diferentes momentos da sua vida passaram pelo crivo da medicina

${ }^{87}$ Mendes-Gonçalves (1994) apresentou as exposições de Freidson, todavia, em nossa opinião trabalhou com grau de prioridade distinto ao realizado por Schraiber.
} 
médico e vinculado às contribuições anteriores do campo da saúde coletiva. Desse modo, o epicentro da análise é a prática médica nas tendências históricas gerais e não o seu contrário, em outros termos, da característica particular, a autonomia, se analisa o movimento geral. O termo autonomia abrange tanto a dimensão objetiva do agente no trabalho, aspectos técnicos do oficio na divisão interna do trabalho médico e na divisão social do trabalho geral, assim como, quanto subjetivamente, a validação social da categoria profissional e a representação simbólica da prática, e ainda mais a autonomia também projetada como ideal da prática médica.

A transição do ofício liberal para a medicina tecnológica tem profundas implicações na integralidade do trabalho médico. A autonomia se reconfigura nesse processo histórico contraditório de permanência e mudança, na perspectiva ideológica e subjetiva, o ideal se mantém, em contraste, concretamente, existe solapamento da forma anterior com o processo de trabalho tecnologizado. Em síntese, enquanto o assalariamento e a forma empresarial e tecnológica avançam, a representação dos médicos valoriza a especialização e incorporação tecnológica como ressignificação e manifestação de autonomia (Schraiber, 1993).

Donnangelo (1975) abordou a heterogeneidade de inserção no mercado de trabalho e o paralelo com posições na ideologia ocupacional, logo da dimensão material desdobra-se dialeticamente à dimensão ideológica dos profissionais. A questão ideológica para a autora não versa sobre um aspecto subjetivo desvinculado do trabalho ${ }^{88}$, ao contrário, Donnangelo indica que o entendimento dos profissionais a respeito de sua condição se relacionava em qual posição de propriedade dos meios de produção, da estratificação interna da categoria, vínculo empregatício e da renda (Donnangelo, 1975, p.120). Contudo, em Schraiber (1993) as práticas desiguais e identidades diferenciadas se inserem em uma integralidade. As pluralidades das trajetórias de vida e de formação resultam na atuação profissional em distintas especialidades, sendo característico do processo de especialização, o desenvolvimento da divisão interna do trabalho médico

\footnotetext{
${ }^{88}$ Provavelmente influenciada pela crítica de Gramsci (2008) ao fordismo "A ideologia nasce do chão da fábrica". A heterogeneidade vincula-se à posição no mercado, todavia, a ideologia não é reflexo mecânico da condição objetiva, a autora cita como os médicos mantinham, muitas vezes, o ideal do exercício liberal em contraste com sua própria inserção no mercado de trabalho.
} 
através das mediações técnicas, mas configuradas socialmente. Nesse sentido, as assimetrias e desigualdades entre os profissionais estão presentes.

Na complementaridade de Donnangelo, Mendes-Gonçalves se debruça sobre as formas sociais do trabalho médico como "ângulo estratégico" para a análise dos serviços de saúde na estrutura social capitalista. $\mathrm{O}$ autor parte do estudo da história do trabalho médico, contudo ao investigar as determinações estruturais, aborda a prática médica como um todo, sendo o trabalho, o núcleo para o entendimento das características gerais da historicidade da prática (Mendes-Gonçalves, 1979). No prosseguimento de sua obra se aprofunda qualitativamente a reflexão do trabalho em saúde. O trabalho é abordado como como categoria social fundamental, logo, tem significado maior do que o entendimento pela articulação com as demais práticas. Para tal desenvolvimento, o autor se baliza pela teoria marxiana ${ }^{89}$ e reconstitui ontologicamente o trabalho em saúde, assim como, analisa a historicidade da dimensão das necessidades e das práticas em saúde no capitalismo. Em nosso entendimento, trata-se da principal obra de conceituação do trabalho em saúde baseada na teoria marxiana.

O principal desenvolvimento de Mendes-Gonçalves refere-se à transição de objetos de estudo: da exclusividade do trabalho médico para o trabalho em saúde em geral e suas expressões particulares entendidas também na dimensão da atuação das demais profissões nos serviços. Em Tecnologia e Organização Social das Práticas de Saúde. Características Tecnológica do Processo de Trabalho na Rede Estadual de Centros de Saúde de São Paulo (1994), aborda a realidade dos médicos subdivididos por suas funções (sanitárias ou consultantes), as enfermeiras e os funcionários de nível médio de enfermagem. Essa transição da prática médica para o conjunto dos profissionais em saúde, não ignorou o predomínio do ofício médico sobre os demais processos.

${ }^{89}$ Conforme termos de Marx e Engels:

O modo pelo qual os homens produzem seus meios de vida depende, antes de tudo, da própria constituição dos meios de vida já encontrados e que eles têm de reproduzir. Esse modo de produção não deve ser considerado meramente sob o aspecto de ser a reprodução da existência física dos indivíduos. Ele é, muito mais, uma forma determinada de sua atividade, uma forma determinada de exteriorizar sua vida, um determinado modo de vida desses indivíduos. Tal como os indivíduos exteriorizam sua vida, assim são eles. O que eles são coincide, pois, com sua produção, tanto com o que produzem como também com o modo como produzem. O que os indivíduos são, portanto, depende das condições materiais de sua produção. (Marx e Engels, 2007, p.87) 
Obviamente, Donnangelo $(1975,1976)$ e Arouca (1975) tinham o entendimento da composição profissional plural dos serviços de saúde, contudo não elaboraram teoricamente para tal composição. $\mathrm{Na}$ transição do trabalho médico para o trabalho coletivo em saúde, Mendes-Gonçalves, cuidadosamente, observa que a utilização do termo "trabalho em saúde" é uma abstração ${ }^{90}$, concretamente não existe trabalho em saúde porque se trata de uma ideia geral, o trabalho é realizado na dinâmica concreta e particular por cada categoria profissional em seu processo de trabalho específico. Contudo, na abstração se percebe a combinação social desses trabalhos e o seu caráter geral ao passo que por meio de diferenciações desenvolve as suas particularidades.

Nessa perspectiva, a análise de Mendes-Gonçalves desmistifica a abordagem ideológica da prática médica e baliza esse como qualquer outro trabalho que se diferencia por seu estatuto técnico (ampara-se categoria marxiana de trabalho concreto); em segundo lugar, pondera que essa concepção parte da aparência social de superioridade de trabalho por maior acesso dos sujeitos a renda e poder; em último lugar, vinculada a essa aparência ao entendimento dos consumidores desses serviços que reforçam o prestigio da categoria médica. Observamos pelo último aspecto que a dimensão ideológica presente na história e sociabilidade são aspectos fundamentais para o entendimento do trabalho médico. Mendes-Gonçalves assinala que formas do conhecimento que corroborem positivamente na diferenciação ideológica tradicional da pratica médica reforçam "o caráter da reprodução da reprodução alienada e alienante” (Mendes-Gonçalves, 2017, p.300).

Assim sendo, destaca que a valorização do ofício médico provida pelo processo histórico de medicalização associado ao Estado conferindo as prerrogativas de domínio intelectual do processo e da estratificação social desse segmento profissional são características próprias em relação aos demais trabalhadores das ocupações em saúde. Logicamente, esse aspecto será fundamental na divisão social do trabalho capitalista em saúde. Acerca da prática médica como oficio liberal, Mendes-Gonçalves sinaliza que a constituição do trabalho em saúde no capitalismo tem no profissional médico sua figura central, responsável pelo diagnóstico e terapêutica. Em uma fase de relativa "escassez de instrumentos", esse profissional pode ser proprietário e ter controle do processo laboral.

90 "É claro que não se pode, entretanto, pensar algo como o "trabalho em saúde em geral"(...) só cabendo, em níveis ainda relativamente abstratos, mas não "gerais", referir-se a formas históricas de sua realização.” (Mendes-Gonçalves, 2017, p.333-334) 
Contudo, esse tipo de trabalho pode ser dividido na elaboração e na execução, com o processo de especialização e complexificação do trabalho coletivo, a divisão social do trabalho se aprofunda.

A distinção do caráter ontológico e do processo histórico capitalista do trabalho em saúde, permitem ao autor não "sacralizar" ou "eternizar" as profissões em saúde. Desse modo, diferencia as possibilidades da realização do trabalho humano coletivo teologicamente orientado e não sua dimensão alienada que se volta contra o próprio homem. Nesse sentido, o autor aponta a contradição da dimensão técnica e das relações sociais, desse modo, a naturalização dos escopos de atividades ou competências não se resume as questões de ordem pragmáticas racionais da melhor disposição técnica, ao contrário é clivado pelos interesses de classe. O domínio intelectual e a definição de prerrogativas são simultâneas à reprodução das classes sociais conformando uma realidade de trabalho que, não necessariamente o potencial, do trabalho coletivo humano é efetivado devido as premissas históricas capitalistas.

Distintamente dos autores da teoria do processo de trabalho em saúde, Arouca (2003) não aborda a conformação técnica do trabalho médico. No entanto, o autor percorre caminho alternativo e desvela aspectos relevantes da prática, fundamentando o cuidado como processo de trabalho médico. Mais precisamente, Arouca expõe como a relação entre o médico e o paciente é profundamente assimétrica, cabendo a concentração do saber ao primeiro e a destituição do conhecimento aos demais indivíduos. O cuidado se insere em relação de troca na sociedade capitalista, na qual o médico por deter tal conhecimento se encontra em posição diferenciada na divisão social do trabalho. Na definição do autor, a dinâmica do processo de trabalho era entendida como produção da vida concreta enquanto atividades "infra estruturais" uma supra determinação do econômico sobre o conjunto da formação social, devido a interpretação althusseriana. Todavia, Arouca amplia o leque teórico e associa a atividade laboral do médico ao tipo de trabalho especifico produtor de mercadorias vinculadas à intervenção de valores vitais.

De todo modo, em Arouca também está presente a transição do estudo da prática médica articulada com outras formas sociais para o trabalho em saúde de forma ampla. $\mathrm{O}$ autor a realiza na forma mediatizada da política canalizada na projeção da proposição de sistema de saúde encampada pelo movimento da reforma sanitária. Sendo assim, o autor aponta que desenvolvimento técnico científico poderá desenvolver um caráter 
progressivo ao se transformar o trabalho médico por meio do Estado, esse aspecto se desdobra na perspectiva política do autor, embora destoe das análises dos autores da teoria do processo de trabalho em saúde acerca do caráter histórico da técnica capitalista e da relação com o Estado (tecnocracia).

3.1.1 O Sentido Social da Complexificação do Trabalho Médico e das Ocupações em Saúde

$\mathrm{O}$ conjunto dos autores ao analisarem os seus respectivos objetos apontam a crescente complexidade técnica e social relacionada ao trabalho médico e das demais ocupações em saúde, ou melhor, as transformações significativas do processo de organização capitalista do setor são expressões da complexificação do trabalho social combinado. Nessa seara, as transformações produtivas inerentes ao capitalismo nos serviços de saúde correlatas ao desenvolvimento científico desembocam no aumento da especialização e da incorporação tecnológica.

Arouca (2003), não obstante, a crítica ideológica à medicina preventiva, especificamente ao caráter ideológico discursivo e a consideração dessa como uma reorganização de conhecimentos anteriores, observa que essa é proponente da transformação da "atitude médica", pois se apresenta como contraposição ao modelo da medicina curativa, sobretudo, em relação a sua ineficiência. De acordo com a medicina preventiva o processo de especialização concentrada nos paradigmas biológicos sucumbiu à formação humanística e o contato nas relações de saúde em comunidades exigiriam outros conhecimentos.

Paralelamente, Arouca observa a instauração de uma nova relação de trabalho mais complexa, na qual o escopo do cuidado amplia os elementos transitando da abordagem clínica individual para a coletiva: família e comunidade. Temporalmente, da intervenção momentânea da enfermidade para todos os momentos da vida ${ }^{91}$. É nessa chave que o autor localiza o médico como trabalhador social no sentido mais amplo do

${ }^{91}$ Conforme texto de $O$ Dilema Preventivista "O próprio Abad Gomes especifica o conteúdo deste movimento ao dizer que ".... Medicina Preventiva trata de... mudar uma atitude tradicionalmente isolada e conquistada dentro da cura individual dos doentes para uma atitude de compreensão da missão médica como aquela de alcançar para todos os seres humanos da comunidade, em que o médico trabalha, um estado de saúde" (Arouca, 2003, p.38) 
termo: "O médico deve compreender a complexidade do campo da saúde, bem como seus objetivos e o papel desempenhado por todos seus elementos" (Arouca, 2003, p.39). Arouca sintetiza a complexidade envolvida no trabalho médico em três âmbitos: o progresso científico tecnológico; a concepção social e histórica de saúde para além da acepção fisiológica e a complexificação da vida social.

Em Mendes-Gonçalves (2017), a complexidade contemporânea na relação em saúde é interpretada a partir da teoria marxiana, logo, o desenvolvimento das técnicas na relação homem e natureza complexifica toda formação social. A reflexão sobre os instrumentos e meios de trabalho, consequentemente, a técnica e sua complexificação permeiam sua obra. Nesse sentido, o desenvolvimento das forças produtivas tem a tecnologia como grande expoente do processo histórico de intervenção humana potencializada na transformação da natureza.

O autor desenvolve a acepção ampla do termo tecnologia vinculada ao trabalho coletivo em saúde visando responder à complexidade da relação social contemporânea em saúde. As formulações sobre o trabalho coletivo em saúde partem do pressuposto da cooperação humana na atividade laboral e objetivam uma efetivação do trabalho dotado de significado e sentido praxiológica no autor. Sendo assim, a categoria teórica tecnologia é desenvolvida para conciliar a dimensão técnico-científico da epidemiologia e a centralidade da prática clínica entendida como processo de trabalho, dessa maneira, o objeto, finalidades e processos de articulação dos instrumentos com a ação propriamente dita das práticas em saúde se condensam nessa acepção ampla ${ }^{92}$ (Mendes-Gonçalves, 1994).

A crescente complexidade do trabalho em saúde refletiu proposições de processo trabalho coletivos com diversas denominações: trabalho em equipe; trabalho multiprofissional, nos quais a realização de novas formas organizativas, responderiam a

92 “A crítica à concepção restrita do conceito de tecnologia foi tomada como uma das motivações gerais deste estudo, e algumas considerações foram feitas, no sentido de se precisar as alternativas gerais de aplicação desse conceito por referência ao processo de trabalho. Tratar-se agora de particularizar essas questões em relação aos processos de produção de serviços de saúde" (MendesGonçalves, 1994,p.55). 
necessidade de ampliação e alteração de escopo e objetos das ocupações em saúde e na configuração de modelos não médico-centrados.

A discussão sobre o papel desempenhado na teoria da complexidade tem influenciado muitos debates no ambiente intelectual contemporâneo. Na crítica à ciência moderna, Morin (2007) apresenta como os fundamentos epistemológicos e paradigmas científicos operam simplificações para sua viabilização, transpondo o debate para nossa temática. A discussão de Morin aponta aspectos significativos para as formações em saúde. Contudo, diferenciamos a abordagem da complexidade a respeito do caráter da ciência moderna, sobretudo, por uma questão de estatuto, parte dos estudos sobre a ciência utilizam da premissa weberiana de autonomia relativa desse campo, decerto para a interpretação de seus agentes a mera aplicação de tendências gerais históricas são insuficientes para a apreensão da esfera científica. Todavia, em nosso entendimento, as ações dos indivíduos tanto no âmbito da elaboração científica quanto na dinâmica laboral ocorreram sob a racionalidade instrumental que para além dos seus limites paradigmáticos, atuaram em consonância com o regime de acumulação do capital e da produção de mercadorias. Dessa forma, não abordamos a ciência, a técnica ou mesmo o trabalho como campos de autonomia relativa, mas como componentes de totalidade. Nos autores da interpretação marxista clássica do trabalho, transcender o paradigma biomédico e corresponder a complexidade da relação de saúde ocorre pela complexidade do trabalho social combinado e demais relações sociais históricas.

\subsubsection{Proletarização Peculiar dos Médicos no Brasil e as Ocupações em Saúde}

A significativa análise do assalariamento dos profissionais médicos e o solapamento do ofício liberal é elemento central da interpretação marxista clássica sobre o trabalho em saúde. Sobre essa transição realizada pioneiramente por Polack (1972), destacamos que o processo histórico de assalariamento no capitalismo industrial não é elemento isolado e integra um processo histórico e social mais amplo. No processo histórico capitalista típico, o assalariamento é uma "resultante" de um longo período constituído por trabalhadores "formalmente livres" que vendem sua força da força de trabalho, com a capacidade de atividade laboral e desprovimento de meios de auto subsistência. O processo histórico de destituição direciona a proletarização. Essa destituição é ampla e condensa fatores materiais: os meios e instrumentos e, aspectos sociais como o conhecimento e o controle do trabalho, sendo que a constituição da 
manufatura e posteriormente através da maquinaria e grande indústria viabilizam a extinção do ofício. Essa separação é pré-condição para a acumulação capitalista nos moldes industriais ${ }^{93}$.

Na análise da constituição moderna da medicina, a consolidação do profissional liberal com o monopólio da prática e com a prerrogativa de auto regulação da corporação (Freidson, 2009) são aspectos fundamentais. Nas análises da sociologia das profissões da medicina, encontra-se o paralelo com o modo "artesanal" de oficio ${ }^{94}$ e o exercício liberal da medicina. Tal analogia se baseia na relação do conhecimento do artesão com o seu fazer, sua propriedade dos meios e instrumentos, logo, existira semelhanças entre a destreza manual e a base técnica tipicamente artesanal. Contudo, tal paralelo histórico deve ser relativizado, pois as corporações de ofício tinham prerrogativas para o seu exercício autorreferenciado baseadas na tradição características típicas de relações sociais pré-capitalistas. A constituição contemporânea dos médicos inaugura-se na associação com o Estado nos parâmetros laicos da modernidade tipicamente capitalistas. Desse modo, sua inserção profissional liberal e relação com o conjunto da sociedade ocorre por meio da chancela estatal do monopólio da profissão, ou no emprego e função das intervenções estatais.

Interpretamos que as considerações de Polack (1972) analisavam a vinculação do ofício liberal na constituição capitalista industrial no qual o paradigma taylorista se ampliava para os setores fabris e o conjunto das profissões liberais ainda resguardaram autonomia do mercado (Braverman, 1987). Dessa maneira, a massiva aplicação do taylorismo nos países industrializados durante o período de expansão do capitalismo no

${ }_{93}$ Historicamente, sobretudo no caso inglês, acontece sob a base do processo violento de proletarização dos camponeses associado ao processo de acumulação primitiva do capital (Marx, 2010).

94 “A marca mais característica do primeiro é a proximidade com o trabalho artesanal, designação aqui usada apenas no sentido ilustrativo do termo, dado que curiosamente é sob esta modalidade que a prática médica adentra a produção social no modo capitalista de realizá-la. Este traço, aparentemente curioso mas mais exatamente tradução da peculiaridade do trabalho médico, chama a atenção pelo contraste com os demais trabalhos na sociedade, pois a medicina manter-se-á "artesanal" por quase um século e meio, tempo em que a dinâmica das forças produtivas dos outros trabalhos sociais já terão de muito ultrapassado até mesmo as formas mais simples de trabalho cooperativo" (Schraiber, 1993, p. 179) 
final do século XIX e início do XX, em especial, a racionalização sob os princípios da separação entre elaboração e execução (parcialização); padronização e prescrição de movimentos; disciplina no trabalho; do trabalho e especialização não atingiu a "forma de trabalho" dos médicos. Embora, o aumento da produtividade considerável possibilitou o surgimento de parcelas da população com renda para o consumo dos serviços médicos, reafirmando a sua posição liberal.

Posteriormente, a transição para o assalariamento ocorre em período correspondente a predominância da modo de regulação fordista. Se por um lado, os elementos concernentes a base técnica do ofício não são atingidos com a automatização da linha produção e a maior produção de bens, por outro, o fordismo instaurou um regime de acumulação do capital sustentado na produção de massa, do aumento da produtividade dos bens e possibilitou o aumento das taxas de lucro. Esse processo culminou na organização capitalista do setor de saúde para atender o consumo massivo dos trabalhadores, e consequentemente, a ampliação das estruturas empresariais em saúde, incorporação tecnológica e assalariamento.

Sendo assim, as análises dos autores da interpretação marxista são realizadas entre as décadas de 1970 à 1990 com olhar retrospectivo direcionado ao processo de industrialização e posteriormente ao fordismo na realidade do capitalismo central. Para além dessa visão retrospectiva, a configuração do fordismo periférico (Lipietz,1987) ocorreu de forma significativamente distinta em relação a base produtiva fabril e constituição do operariado, justamente por isso o peso dos empregos estatais e corporativos-previdenciários na atenção médica são tão significativos no Brasil no século $\mathrm{XX}$, pois não existiam parcelas urbanas significativas com renda para consumo de tais serviços. Desse modo, reafirmarmos a constatação de que a natureza do assalariamento do profissional médico é consideravelmente distinta do processo clássico de assalariamento no capitalismo industrial, ainda mais, se compararmos as características do assalariamento na realidade brasileira que não ocorre nos moldes clássicos.

Todavia, Braverman (1987) assinala o desenvolvimento capitalista abrange diversas funções de ofícios liberais, sobretudo, trabalhadores de escritório, comércio menor e "prestadores" de serviço transitam para uma relação de proletarização entre o século XIX e XX. A partir dos elementos expostos, a tendência do assalariamento destacado pelos autores da interpretação marxista pode ser caracterizada, mais precisamente, como um processo de proletarização peculiar. As características próprias 
do processo de proletarização são a cisão entre o agente da atividade e os meios de produção entendido em acepção ampla, a incorporação de capital e a organização empresa inviabiliza o ofício liberal.

A peculiaridade dessa condição proletária é a permanência da formação técnico científica como fundamento da qualificação, mesmo que contraditoriamente esse componente contribua para o menor domínio do trabalhador individual em relação ao trabalho coletivo em um crescente processo de complexificação, pois com o aprofundamento da heterogeneidade e especialização, cada trabalhador conhece qualitativamente menos o conjunto das atividades. Contudo, tal condição de qualificação se mantém tanto pelo elevado desenvolvimento técnico cientifico quanto pelo poder conferido na constituição moderna da medicalização. Particularmente, a respeito dos médicos e em menor medida das demais ocupações tradicionais em saúde, a ampliação da clínica através da medicina social ou política de saúde do Estado configura socialmente a legitimidade da medicina como forma dominante de intervenção sobre o corpo e confere status diferenciado em relação ao conjunto da sociedade.

Concernente à formação educacional, as demais profissões de saúde desenvolvidas intrinsecamente ao processo de especialização, resguardam seu posicionamento pelo domínio técnico e o relativo prestígio social da formação. Contudo, sua inserção na divisão social do trabalho é desprovida do poder constituinte da medicalização do profissional médico, inclusive, o poder médico lhes afronta porque mesmo que possuam domínio técnico sobre determinada situação, a prerrogativa do diagnóstico e terapêutica cabe ao médico. A associação política da categoria médica com o Estado persiste mesmo com diversas transformações, a valorização da qualificação profissional e o posicionamento "privilegiado" no mercado de trabalho os distancia dos demais trabalhadores proletarizados dos serviços de saúde e dos outros segmentos qualificados.

A definição de proletarização peculiar insere o assalariamento na configuração mais ampla da relação social de trabalho e objetiva entender a dinâmica contemporânea do trabalho médico e, suas consequências, para os demais trabalhadores em maior ou menor medida. Por um lado, a simples denominação de proletarização reduz a dinâmica 
de trabalho do médico a uma condição não correspondente a realidade ${ }^{95}$. Por outro lado, o destaque das condições peculiares diferenciando da dinâmica proletária não considera os aspectos gerais da sociabilidade capitalista, entre eles o assalariamento, também não correspondem a vida concreta.

Ainda sobre a proletarização, não se aborda somente a inserção no mercado de trabalho ou a dimensão interna do processo de trabalho, discute-se também estratificação social, ou mais precisamente, em qual fração de social se posicionam esses profissionais. Wright Mill na década de 1960 nos Estados Unidos, forjou o conceito amplo vago da "classe média" para o assalariamento de profissionais liberais, posições análogas as gerências industriais e setores ultra qualificados. Para fins de nosso desenvolvimento, Larson (1980) confere indicações relevantes, sobre a proletarização de profissionais qualificados “não operários manuais" ou “White collar categories” (Larson, 1980) acerca das relações entre posição social, condições de trabalho, as ideologias vinculadas aos tipos de personalidade típicos da classe média.

A título de apontamento crítico à interpretação marxista clássica, o esforço de teorização dos autores parte do pressuposto da constituição capitalista da categoria médica, combinando as características sociais configuradas pelo predomínio biomédico sobre o corpo e na normatização da vida e as transformações do mercado de trabalho. Todavia, ao priorizarem a prática médica não se atentaram ao conjunto do trabalho e dos trabalhadores em saúde, distintamente, dos estudos acerca dos trabalhadores no Brasil. Na produção teórica da constituição da saúde se priorizou a análise da categoria profissional mais qualificada atribuída socialmente e que goza de prestígio nos serviços de saúde, enquanto sobre o conjunto das demais ocupações existem lacunas consideráveis.

Observamos que a maior parte dos trabalhadores das ocupações pertenciam a outras categorias profissionais na década de 1970 e se inserem na relação laboral de saúde nos moldes da proletarização ordinária majoritariamente, ainda que pautados pelo domínio do ofício médico, mas com parâmetros dispares desse profissional. Certamente, a análise desses profissionais apontaria aspectos muito ricos da realidade dos

${ }^{95}$ Embora, a identidade da proletarização com uma acepção da homogeneidade seja um exagero analítico. 
trabalhadores de saúde, por exemplo, a precariedade, a incipiência de profissionais e a exploração características do trabalho capitalista na formação social brasileira.

De outro modo, as relações de trabalho desses profissionais eram indicativos interessantes sobre as influências que os profissionais médicos se deparariam ainda que mantivessem uma posição destacada em relação as demais ocupações. Por exemplo, a proletarização peculiar dos médicos atualmente convive com a instabilidade e flexibilidade dos vínculos empregatícios no mercado de trabalho contemporâneo, situações vivenciadas anteriormente por outros setores dos trabalhadores de saúde ou mesmo as formas organizadas de ação coletiva por melhores condições de trabalho.

\subsection{Trabalho, Estado Nacional e Serviços de Saúde}

As apreciações dos autores da interpretação marxista clássica são díspares em relação a caracterização acerca do Estado, em Donnangelo (1975 e 1976) o Estado cumpriu papel fundamental nos processos de medicalização das sociedades modernas. Não é possível pensar esse processo moderno sem a centralidade do Estado. A obra de Foucault é referência na exemplificação das formas de medicina social, especialmente, a medicina de estado na Alemanha. Em uma sociedade com peso estatal considerável, forjou-se uma medicina com sistema de controle de morbidade e a elaboração de estatísticas sobre o diagnóstico do perfil população. Também nesse exemplo histórico surgiu a carreira estatal para médicos, ou seja, o surgimento da administração médica na estrutura organizativa do Estado, posição privilegiada no século XVIII. No plano social, a medicalização dos indivíduos opera nas famílias, sendo o privilégio da higiene e o funcionamento da medicina como instância de controle social (Foucault, 2003) sob a tutela estatal. Na sua fase moderna, o Estado constituiu formas diferenciadas e articuladas de política de saúde com objetivos distintos: focalização nos pobres, a política para a saúde da população geral e o mercado para a saúde privada para os ricos

Se por um lado, a referência foucaultiana serve para compreensão da atuação do Estado na provisão moderna de serviços de saúde, por outro, cabe 
desenvolvimento teórico para o papel desempenhado pelo Estado na realidade brasileira ${ }^{96}$. Na apreciação de Donnangelo, o Estado como agente político-econômico privilegiado no caso brasileiro, tem a noção implícita do subdesenvolvimento, e formata a política estatal de saúde sob tal condição ${ }^{97}$. A autora destaca que as classes urbanas pressionaram pela provisão de serviços e contraditoriamente o Estado cedeu para atenuar às tensões sociais. Assim como, a política estatal de saúde conformou o mercado consumidor dos serviços privados. Também cabe frisar, que em Donnangelo e nos autores da teoria do processo de trabalho em saúde não existe elaboração de intervenção sobre o Estado.

Na avaliação de Arouca (2003), embora parta do mesmo entendimento do caráter estatal da medicalização, desenha um parêntese para a formulação de qual papel o Estado poderia cumprir em relação à política pública de saúde na América Latina. Ao analisar a influência da medicina preventiva no continente, estabelece que três dimensões ideológicas justificam sua ampliação na década de 1950. O primeiro e mais nítido, referese as condições de vida e de saúde de amplas parcelas da população na qual intervenções relativamente simples poderiam alterar significativamente diversos agravos; na segunda dimensão, o preventivismo ofereceu um conjunto articulados de conceitos com perspectivas de mudanças de atuação práticas sintetizadas no termo "nova atitude"; terceira dimensão, os departamentos de medicina preventiva se constituiriam um “aparelho ideológico material" (Arouca,2003). Nesse horizonte, o autor caracteriza que o discurso preventivista carrega em si três perspectivas conflitantes, a crítica: que vincularia a medicina a estrutura social; apologética que entenderia a medicina preventiva com uma nova "doutrina" que resolveria as questões e a perspectiva tecnocrática das intervenções própria da saúde pública. De acordo com o autor:

Esta configuração do seu discurso diante da realidade política latinoamericana, em que o Estado tem frequentemente assumido total ou parcialmente o controle das ações de saúde, através dos diferentes sistemas previdenciários, leva, como tendência, a que a Medicina Preventiva se afaste, progressivamente, das suas relações com a sociedade civil para aproximar-se do Estado em sua dimensão tecnocrática. (Ibid, p.142)

\footnotetext{
${ }^{96}$ Por exemplo, o Estado e as corporações profissionais foram grandes empregadores da categoria médica para a prestação assistencial por meio de assalariamento, inclusive, em maiores proporções do predomínio do ofício liberal nos países capitalistas desenvolvidos.

${ }^{97}$ Essa caracterização do papel desempenhado pelo Estado é desenvolvido por Pereira (1970)
} 
Para fins de nossa análise essa aproximação do caráter tecnocrático e do Estado é um ponto chave na perspectiva política de Arouca, embora o autor sinalize que essas características possibilitaram outras influências teóricas sobre os objetos de saúde. O autor desenvolve que os sujeitos envolvidos nos aparelhos do Estado não estariam submetidos às relações de produção, mas às representações de igualdade, onde a educação e saúde seriam tratadas como bens sociais por esses agentes ${ }^{98}$, sustentados pelos preceitos formais de cidadania e da igualdade formal e a universalidade dos direitos humanos. A partir dessas premissas, Arouca defende a possibilidade da existência de outro modelo sob o controle do Estado que poderia conferir condições distintas para o trabalho e para a prática de saúde em si. O Estado reconfiguraria o setor de saúde, mantendo a função da medicina no sistema capitalista, porém com aspectos progressivos baseados no pressuposto da igualdade e bens sociais. O poder político estatal seria um agente de controle das empresas e do modus operandis da dinâmica capitalista ${ }^{99}$. Nos termos de Arouca:

"O outro modelo, quando o Estado assume o controle das ações de saúde; é possível, a partir de uma reforma completa nas condições de trabalho, incorporar aos praticantes as chamadas "atitudes preventivas", desde que elas façam parte das relações sociais de produção e consumo do cuidado e, a partir daí, estabelecer uma reforma do ensino que se adapte às novas condições de prática.

O Estado pode promover uma rearticulação do setor de saúde, mantendo as funções da Medicina diante da sociedade capitalista, através de uma reorganização do trabalho médico, de uma recolocação do seu poder político e de um controle das indústrias ligadas ao setor. Evidentemente, tal procedimento pode levar a uma maior eficácia no desenvolvimento das funções da Medicina diante da sociedade, pela introdução de um sistema racionalizador do trabalho médico. Neste caso, as concepções preventivistas podem se incorporar à prática, abandonando seu berço de origem junto à sociedade civil. " (Ibid, p.239-240)

98 “ $4^{\circ}$ A sociedade capitalista no,plano do social afirma-se igualitária e universal.(...)

Para os sujeitos das ações no interior dos aparelhos de Estado, não é a lógica de produção que está imperando, mas, sim, as representações desta lógica, de onde a dimensão do universal e do particular regem as relações concretas entre os homens, no mundo das representações. A educação e a saúde são bens sociais e não mecanismos de reprodução das relações e características da força de trabalho. Portanto, a escola deve ser democrática e a Medicina integral, no plano das representações que enfatizam na prática as suas demonstrações. (Ibid, 236-237)" 
Em nosso entendimento, contraditoriamente, enquanto o autor utiliza a crítica o caráter supostamente neutro da ciência quando na verdade cumpre um papel "funcional" ao status quo, aposta em um papel do Estado como se fosse um instrumento político que poderia ser desvinculado da formação social capitalista, mesmo na sua dimensão tecnocrática. Possivelmente, tal posição parte de uma interpretação discutível da autonomia relativa do Estado conferida por Poulantzas (1977) ${ }^{100}$. Em síntese, a tese desenvolvida por Poulantzas (1977) apregoa que o Estado enquanto instrumento político necessita de autonomia relativa diante da fração de classe ou bloco no poder com vistas a cumprir o papel de organizador do interesse geral da burguesia e do conjunto de suas frações, em determinado momento, mediando conflitos entre essas. Essa reflexão também desvela que o funcionamento político do Estado não é totalmente determinado pela estrutura econômica, logo, a dimensão da política também teria relativa autonomia da dimensão econômica, essa reflexão que permeia a obra de Poulantzas também é relacionada para a dimensão do "campo da luta de classes", sendo um dos seus elementos que os interesses e posicionamentos dos agentes integrantes da burocracia estatal não são coincidentes às frações de classe que dirigem o Estado, esses agentes seguiriam valores e interesses próprios, sintetizados pelo autor no termo "burocratismo" (Poulantzas, 1977 e Saes,1988). Arouca (2003) a partir dessa reflexão projeta que os agentes técnicos da burocracia - tecnocracia - poderão cumprir aspectos progressivos, visto que se pautam pela defesa de direitos universais da cidadania em sua visão.

A formulação de Arouca sobre o Estado vincula-se à proposição de outro modelo vinculado a uma concepção reformista da sociedade brasileira por meio do Estado e contribuiu no plano teórico e político do movimento da reforma sanitária. Não à toa, o próprio Arouca foi liderança do movimento social, da comunidade acadêmica e liderança parlamentar. Contudo, referente ao objeto trabalho em saúde, a perspectiva de que o Estado cumprirá papel de transformador das relações de capital e trabalho nos serviços de saúde é influente. A discussão contemporânea deve problematizar o papel do Estado na gestão e nas condições do trabalho em saúde, vários aspectos do programa da reforma sanitária foram estabelecidos na Constituição de 1988 e na criação do SUS, por exemplo, o aumento da oferta assistencial, em contrapartida, a política estatal encampou iniciativas

100 Ver Saes (1998), acerca da questão da autonomia relativa do Estado. 
no sentido de intensificação e precarização em relação ao trabalho e aos trabalhadores das ocupações em saúde de forma semelhante da organização geral do trabalho no trabalho no capitalismo contemporâneo.

Os autores da teoria do processo de trabalho em saúde não desenvolveram projeção política do Estado nacional na perspectiva reformista próxima a posição de Arouca (2003) Criticamente, pode-se considerar que a temática do Estado foi tratada de forma mais incipiente com o transcurso dos autores dessa escola de pensamento. Para eles a discussão do Estado nacional não é relevante. Contudo, acerca da projeção do papel que os agentes técnicos desempenhariam na produção em saúde por meio do Estado, os autores se diferenciam da caracterização de Arouca. Esses autores partem do diagnostico que a técnica e a ciência não são autoreferenciadas, mas práticas sociais com contradições inerentes. $\mathrm{Na}$ acepção histórica e crítica da técnica, o desenvolvimento técnico é instrumental eficiente, porém, a técnica não seria um compêndio de conhecimentos aplicados como meio para determinados fins alheios de sua lógica, ao contrário, a viabilidade técnica também conformaria tais fins. Tal acepção impediria, por exemplo, a aposta de que o caráter tecnocrático do Estado cumpriria um papel progressivo caso fosse direcionado politicamente para tal, porque inerentemente a sua conformação reside um caráter político de forma análoga à crítica à formação científica na medicina.

\subsection{Perspectivas Contemporâneas da Interpretação Marxista do Trabalho em Saúde}

Os autores marxistas relacionaram a organização dos serviços de saúde ao avanço das relações sociais capitalistas em seus objetos de pesquisa, especificamente, com atenção direcionada à compreensão de como o trabalho médico se articulava com o movimento do capital descrito como monopolista na década de 1970. Mais precisamente, a discussão se concentra na polêmica sobre produtividade ou improdutividade do trabalho médico. De acordo com Arouca (2003), o trabalho médico é produtivo ${ }^{101}$, pois sua ação

${ }^{101}$ Desta forma, o trabalho médico, ao contrário do que consideram alguns autores (Donangelo, 1976 e Pollack, 1972), pode ser diretamente produtivo, ao incorporar-se ao trabalhador coletivo, cuidando da força de trabalho, contribuindo para o aumento da razão, pelo aumento do numerador, ao participar da organização do processo produtivo e mantendo a força do trabalho em condições de ser consumida.

Em síntese, podemos dizer que a articulação fundamental da Medicina refere-se à manutenção, recuperação e reprodução da força de trabalho, à manutenção e recuperação de valores de uso para as 
resultava em melhores condições de reprodução de trabalho aumentando a produtividade do conjunto do sistema, intermediaria a troca e consumo das mercadorias e viabilizaria a realização da mais valia do setor industrial e, consequentemente, resultaria em aumento no processo de acumulação do capital.

Em Arouca (2003), a saúde configura-se uma mercadoria e o trabalhador médico transita em formas de assalariamento: pela indústria; por empresa de prestação de serviços médicos; pelo Estado via a assistência da previdência social no cenário institucional prévio ao SUS (Arouca, 2003, p.231). Segundo o autor, trabalho é diretamente produtivo, devido a compra da força de trabalho se transforma em capital acumulado. No terceiro caso seria mais complexo, visto o custeio dos serviços de saúde pagos pelo trabalhador e pela empresa, mas o fim seria o mesmo a manutenção da força de trabalho. O cuidado médico destinado à superpopulação relativa seria uma relação comercial custeada pelo Estado por uma relação política e ideológica e não de acumulação de capital ${ }^{102}$.

Donnangelo (1976), Mendes-Gonçalves (1979) e Nogueira (2012) discordam e caracterizam o trabalho médico como improdutivo, acerca da relação entre a medicina e o processo de produção econômica, Donnangelo ampara-se na formulação de Polack, em termos compartilhados:

\footnotetext{
"A atenção médica não é um produto, um objeto separável de seu agente, uma mercadoria suscetível de circular como um autêntico valor de troca. Este produto não desaparece ao ser consumido. Quando se dirige à força de trabalho, o ato terapêutico eleva o nível dessa força de trabalho ou contribui para sua manutenção, no quadro de uma reprodução. Ao contribuir para elevar o nível de produtividade, a atenção é indiretamente produtiva". O autor atribui, portanto, uma especificidade ao conceito de trabalho indiretamente produtivo quando aplicado ao trabalho médico "Esta nosologia ambígua não permite confundir a saúde como um setor terciário qualquer, um processo de comercialização, de publicidade, um
}

classes hegemônicas, sendo o trabalho médico diretamente produtivo quando possibilita um acréscimo na mais-valia, e improdutivo quando se refere a pura relação de troca comercial e, finalmente, é indiretamente produtivo quando se refere à reprodução da força de trabalho e atendimento do exército de reserva.

${ }^{102}$ Em síntese, podemos dizer que a articulação fundamental da Medicina refere-se à manutenção, recuperação e reprodução da força de trabalho, à manutenção e recuperação de valores de uso para as classes hegemônicas, sendo o trabalho médico diretamente produtivo quando possibilita um acréscimo na mais-valia, e improdutivo quando se refere a pura relação de troca comercial e, finalmente, é indiretamente produtivo quando se refere à reprodução da força de trabalho e atendimento do exército de reserva. (AROUCA, 2003, p.232) 
serviço. A medicina não tende, essencialmente, ao domínio dos quadros administrativos de economia, mas à definição permanente de um nível de produtividade. As forças produtivas são, por excelência, o seu objeto, razão pela qual a influência da medicina sobre a marcha. O sistema de atenção (médica) tem sob seu controle a parte humana da atividade produção, o trabalho". (Polack, 1972, p.35 apud Donnangelo, 1976, p.34)

Distintamente da caracterização do trabalho improdutivo, Arouca prossegue e desenvolve uma antinomia ao desenhar duas tendências dispares para o mesmo processo. Ao mesmo tempo que a medicina se tornou ela em si a organizadora da produção, distribuição e consumo dos cuidados médicos, existiria uma crise do ponto de vista capitalista na organização dessa produção, ao passo que a prática médica não pode ser transformada em atividade capitalista.

Em nossa leitura, para a apreensão das principais características do trabalho e valor nos serviços de saúde, os autores marxistas do contexto italiano, francês e brasileiro abordaram a reconstituição da força de trabalho com vistas ao operariado fabril e na ampliação do consumo dos serviços de saúde característicos do século XIX e XX. A reconstituição da mercadoria força de trabalho permanece fundamental para qualquer sociedade capitalista, essa dimensão permanece explicita, por exemplo, na reconstituição da força de trabalho na China, considerada como o grande parque industrial mundial ${ }^{103}$. Contudo, a multiplicação de mercadorias como serviços e produtos vinculados à saúde e a consequente, multiplicação das "necessidades próprias do capitalismo" (MendesGonçalves, 2017) ampliam o repertório de produção e realização do valor e são fundamentais para o regime de acumulação flexível (Harvey, 2004). Nesse ponto, a reestruturação produtiva e a crescente automação são a base material para alterações das relações típicas do capitalismo industrial e do regime de acumulação fordista.

Ainda resta a nós, a questão analítica a respeito da relevância da discussão acerca produtividade ou improdutividade do trabalho das ocupações em saúde na contemporaneidade. Contrastamos com a interpretação marxista clássica da saúde

${ }^{103}$ A correspondente disciplina fabril é correlacionada à uma medicina do trabalho que guarda semelhanças com o período da revolução industrial clássica com a atuação de inspetores de fábrica e ingresso na produção de imigrantes de origem rural na produção fabril (Zhang, Wang e Li, 2010). No Brasil, em um cenário de vertiginosa desindustrialização, os aspectos da recomposição da força de trabalho são "fluídos" à vista do observador, pois ocorrem no trabalho informal, na realidade de desgaste do emprego nos serviços entre outros e os agravos de saúde são vistos sob perfis epidemiológicos no território não vinculados à ocupação 
coletiva, pois a dualidade entre produtivo e improdutivo (abstração categorial) não consegue alcançar uma definição geral para o conjunto das atividades laborais no contexto de complexificação do trabalho social combinado, na qual a dinâmica do valor realiza uma simbiose de trabalhos produtivos e improdutivos de ordem material ou imaterial. Nesse sentido, a dedicação de apreensão deve se atentar a relação social histórica de valor e das características centrais do presente regime de acumulação. Consequentemente, com vistas a relação social do valor nos serviços de saúde e o trabalho das ocupações em saúde, destacamos a consideração acerca do valor enquanto uma relação social ${ }^{104}$. Rubin ao comentar a teoria marxiana, aponta:

O valor é uma forma social adquirida pelos produtos do trabalho no contexto de determinadas relações de produção entre as pessoas. Deste ponto de vista, o valor é uma forma social adquirida pelos produtos do trabalho no contexto de determinadas relações sociais de produção entre as pessoas. Devemos passar do valor como magnitude quantitativamente determinada para o valor abordado como uma forma social qualitativamente determinada. Em outras palavras, devemos passar da teoria da "magnitude do valor" para a teoria da forma do valor.

O trabalho não confere, por si mesmo, valor aos produtos; somente o trabalho organizado numa determinada forma social (na forma de uma economia mercantil). Se os produtores estão vinculados uns aos outros como organizadores da atividade econômica formalmente independentes e como produtores mercantis autônomos, então os valores [produtos] de seus trabalhos se confrontam no mercado enquanto "valores" (...). O valor das coisas expressa um determinado tipo de relações entre as pessoas. (Rubin, 1987, p.83-84)

Sendo assim, a reflexão sobre a compreensão das características contemporâneas da relação em saúde passa pelo entendimento da forma social estabelecida e sintetizada no processo moderno de medicalização. Advogamos a pertinência da interseção das relações sociais caracterizadas como medicalização e mercantilização realizada pela interpretação marxista e de como essa chave permanece significativa para apreensão das transformações sociais contemporâneas. Essa interseção desenvolve outra configuração na relação contemporânea em saúde no regime de acumulação flexível e da organização do trabalho pós-fordista ou toyotista.

104 "A teoria de Marx sobre o valor (...) não analisa a relação entre coisas, ou relações entre pessoas e coisas, mas sim as relações entre pessoas que estão vinculadas entre si através das coisas" (Rubin, 1987, p.83) 
Para fins de nossa análise, torna-se necessário o entendimento desse processo posterior a década de 1970. Nesse período, instaurou-se a crise do regime de acumulação fordista nos países capitalistas centrais, em que o epicentro da crise se referiu à tendência de queda da taxa de lucro no movimento do capital. Na economia política, Mandel (1985) caracteriza a ocorrência do fenômeno denominado de supercapitalização que resulta, na hipertrofia dos serviços no capitalismo tardio, visto como, realocação de uma massa de capital sem possiblidade de ser investido e revalorizado no setor produtivo, devido à queda da taxa de lucro. A saída possível para esse capital é viabilizar o lucro médio nas —atividades intermediárias, entendidas como atividades de serviços ${ }^{105}$. As considerações dessas transformações produtivas nos serviços de saúde fundamentarão como os serviços de saúde se convertem em área de valorização e as consequentes repercussões laborais.

Do ponto de vista da organização do trabalho, essas alterações são denominadas amplamente de reestruturação produtiva, toyotismo (ohnismo) ou pós-fordismo. Suas principais características são o just in time (prática de diminuição dos estoques e a produção correspondente com a demanda do mercado); flexibilidade das relações de trabalho; círculos de controle de qualidade; terceirização e subcontratação (Boyer e Durand, 1997). Nitidamente, independente do acesso ao debate da economia política do período no diagnóstico do movimento do capital, os autores da interpretação marxista não tinham possibilidade de interpretação do processo com todos esses elementos.

Destacamos a diversificação da produção e desenvolvimento da variedade de bens e serviços como aspecto central do regime de acumulação instaurado e uma principal alternativa encontrada para a realização do valor na crise do regime fordista. O exemplo clássico da empresa Toyota se baseou na reestruturação da linha produtiva que se organizava na reatividade às demandas do mercado consumidor, mas a variedade de

${ }^{105}$ Em última instância, todas essas tendências correspondem à característica básica do capitalismo tardio: o fenômeno da supercapitalização, ou capitais excedentes não investidos, acionados pela queda secular da taxa de lucros e acelerando a transição para o capitalismo monopolista. Enquanto o — capital era relativamente escasso, concentrava-se normalmente na produção direta de mais-valia nos domínios tradicionais da produção de mercadorias. Mas se o capital gradualmente se acumula em quantidades cada vez maiores e uma parcela considerável do capital já não consegue nenhuma valorização, as novas massas de capital penetrarão cada vez mais em áreas não produtivas, no sentido de que não

criam mais valia, onde tomarão o lugar do trabalho privado e da pequena empresa de maneira tão inexorável quanto na produção industrial de 100 ou 200 anos antes. (MANDEL, 1985, p.272) 
produtos oferecidos diferenciava a empresa na disputa do mercado automobilístico (Ohno,1988). Embora, o exemplo pioneiro do ramo automobilístico seja elucidativo, a relação semelhante de diversificação e aumento do volume da produção ocorre de forma diferenciada na relação social do valor em saúde.

Na dimensão global, a dimensão do fetichismo das mercadorias em saúde atinge níveis inimagináveis nos termos do capitalismo industrial clássico e garantem o regime de acumulação contemporâneo. A mundialização do capital refletiu a hipertrofia das “inovações" das mercadorias da saúde e dos desejos-necessidades vinculados à ela, tanto referente aos medicamentos, produtos, aos procedimentos nos serviços, tais como, análises genéticas, acessos a inovações tecnológicas contínuas de exames de imagem diagnósticas. Bem como, o acesso de planos de saúde como desejo de consumo e expressão das formas securitárias da vida social. A conversão majoritária dos serviços de saúde em área propícia à valorização do capital ou sua subordinação à lógica da acumulação,ou seja, os espaços dos serviços não necessariamente produtivos cumprem aspecto complementar, consomem produtos da indústria e a sua própria prática está conectada com o regime de acumulação.

Sobre o aspecto de mercadorização na relação social da saúde e doença, Polack (1972) afirma um princípio essencial da produção capitalista:

O território da doença e da medicina oferta um campo aparentemente ilimitado da exploração de consumidores; por meio da educação sanitária, opera-se uma transformação pela vulgarização e distorção dos conhecimentos destinados à fornecer as normas alimentares, higiênicas, corporais ou rítmicas favoráveis à expansão da demanda individual por diversos produtos industriais

As revistas "médicas" são geralmente mais nocivas em suas abordagens do que a ansiedade hiponcondriaca dos pacientes, consumidores virtuais. Um amontoado de slogans publicitários se sustentam diretamente ou exclusivamente a partir das assertivas médicas. Dentro desse domínio, o exemplo oriundo dos Estados Unidos e, mais particularmente, a propaganda televisa. A longevidade, a beleza, a disposição sexual são correlacionadas a saúde fisiológica do corpo em um sincretismo desconcertante. Leveduras e vitaminas, alimentos selecionados, aparelhos físicos diversos, cremes dentais. nesses itens excepcionais se resumem as qualidades necessárias para nos elevarmos ao fardo de nossa condição terrena ${ }^{106}$ (Polack, 1972, p.111) (tradução nossa)

${ }^{106}$ Le territoire de la maladie et de la médecine offre un champ apparememente ilimité d'exploitatiton des consommateurs; seule peut le borner l'education sanitaire ambiante, ele-même travestie par une vulgarisation et une distorsion des connaissances destinées à fournir les normes alimentaires, 
Ao se apreender as relações contemporâneas em saúde, observamos que a fronteira dos estados considerados patológicos e normais são redimensionados pela valoração social dos interesses do capital, logo as situações devida não normatizadas por tais valores se ampliam consideravelmente. Por certo, os padrões de desempenho estabelecidos pela sociabilidade capitalista por meio do ritmo de vida e dos valores vigentes conformam adoecimentos e formatam essas dimensões no parâmetro de normalidade (Conti, 1972). Ainda referente à medicalização, os serviços de saúde e a formatação da conduta de vida dos indivíduos em todas as suas fases atingem patamares inéditos ao passo que o volume das intervenções técnicas e protocolos sobre o corpo e a mente acompanham tal universalização. Do mesmo modo, o predomínio biomédico de caráter positivista permanece como norte para os profissionais especializados pela educação formal. Desse modo, a intervenção respaldada tecnicamente e ideologicamente sobre o corpo e o meio e as práticas em saúde como ação social reiterativa dos indivíduos permanece, sendo a melhor expressão disso, o aumento da ultra-especialização.

Essa ampliação das mercadorias, do consumo e da racionalidade instrumental em saúde fundamenta-se no estabelecimento de princípios em determinadas operações: primeiro, a ampliação da prevenção para todos os momentos da vida, nos aspectos concernente às "ameaças" e a projeção de riscos dos hábitos de vida (Illich, 1975 ;Castiel,1999); segundo, diversos procedimentos estritamente necessários para determinadas condições fisiológicas ou psíquicas especificas são ampliadas e "generalizadas" para maioria indivíduos, por exemplo, a utilização massiva de medicamentos psiquiátricos para tratamento de déficit de atenção (Brant e Carvalho, 2012 e Domitrovich e Caliman, 2017) ou aumento vertiginoso de cirurgias bariátricas (Marcelino e Patricio, 2011). O exercício contemporâneo de reflexão acerca das

hygiéniques, corporelles, esthétiques ou rythimiques favorables à l'expansion de la demande individuelle des diver produits industriels.

Les revues < médicales> sont généralement les moins nocives de ces formes d'inscursion dans l'anxieté hypocondriaque des patients, conssomateurs virtuels. Une foule de slogas publicitaires s'appuie directement ou allusivemente sur des assertation médicales. Dans de domaine, l'exemple vient des Etats-Unis et plus particulièrment de la publucité télévisée. La longevité, la beauté, la force sexuelle soont corrélées à la saine physiologie du corps dans uns syncrétism déroutant. Levures et vitamines, aliments choisis, appareils physiques divers, pâtes dentrifices aux ingredientes excpeptionnel résument em eux ler qualités nécessaires pour l'arrachment à notre pesanteur terrienne; 
"necessidades necessárias em saúde" contemporâneas (Mendes-Gonçalves, 2017) nos remete ao movimento mercantil de expandir procedimentos técnicos específicos e generalizá-los como "único meio" de homens e mulheres devem passar nos momentos da vida. Para além da conversão do específico no universal, o supérfluo também vira necessário.

A multiplicação de mercadorias nos serviços de saúde e a construção das necessidades com a fundamentação ideológica da sociedade do desempenho na qual o complexo dos suplementos alimentares, academias, drogas psiquiátricas, cirurgias estéticas, cosméticos, clareamento dental e várias outras, sinalizam que o regime de acumulação do capital tem suas próprias necessidades e os indivíduos projetam todo esse rol de necessidades como meios de viver (Heller, 1986; Mendes-Gonçalves, 2017), logo o sono e o despertar são regulados pela medicalização, o humor durante o dia não poderia ser diferente. As formas de relações afetivas são valoradas pela preparação estética para a competição em aplicativos de relacionamento.

A alteração do consumo em saúde com a significativa ampliação do rol de atividades das mercadorias e serviços de saúde e, consequentemente, da participação econômica do segmento no conjunto da economia e da lucratividade, necessariamente precisa impor sobre o trabalho das ocupações em saúde o estabelecimento de inúmero protocolos e procedimentos pautados pela mensuração de produtividade. A teoria crítica desenvolvida acerca da multiplicidade das mercadorias em saúde não implica desconsideração do aumento da capacidade humana de intervenção reparadora mantenedora da vida, de intervenções revolucionárias diante da natureza de novos diagnósticos e terapêuticas. Todavia, essa mesma capacidade produz intervenções desnecessárias e mercadológicas ${ }^{107}$.

Indubitavelmente, na seara da complexificação do trabalho social combinado, o processo de trabalho e processo de valorização nas atividades materiais e imateriais significam um movimento do capital que arregimenta milhões de trabalhadores no Brasil.

\footnotetext{
${ }^{107}$ A contradição se estabelece na condição humana, a redução significativa da mortalidade infantil em sociedades medicalizadas caminha em paralelo com inúmeros protocolos e procedimentos técnicos sobre a saúde reprodutiva feminina que reflete necessidades econômicas ou corporativas, a exemplo, da multiplicação de cesárea de forma indiscriminada no caso brasileiro
} 
A posição dos trabalhadores dos serviços em sua pluralidade guarda sempre relação com a cadeia produtiva do valor no âmbito da produção, circulação, realização ou reprodução do capital. A questão clássica da relação do valor se recoloca no século XXI, pois tamanha multiplicação de mercadorias e ampliação de estatutos patológicos correlacionadas à expansão do setor não poderia estar dissociada do movimento de valorização e reprodução ampliada do capital.

A critério de balanço das obras da interpretação marxista clássica, o conjunto dos elementos contemporâneos não estavam presentes de forma plena na organização dos serviços de saúde na década de 1970 no Brasil, isto é, a forma de organização dos serviços se assemelhavam a organização fordista do trabalho e logicamente, as relações de emprego, exigência e aumento do ritmo de trabalho não estavam colocados. Em síntese, o processo de trabalho não tinha o presente nível de intensificação. Contudo, a concentração analítica dos autores sobre o processo de proletarização peculiar dos profissionais médicos pode ter limitado sua apreensão acerca da intensificação do processo de trabalho, seja pela realidade de outros profissionais de saúde que convivam com formas de exploração consideráveis que ainda não tinham atingido os profissionais médicos. Mesmo em relação aos médicos, é improvável analisar que o movimento de assalariamento pela organização capitalista não continha elementos de um processo de intensificação de ritmo de trabalho em relação ao padrão anterior de ofício liberal.

Desse modo, o diagnóstico de intensificação do processo de trabalho nos serviços em saúde não é abordado pelos autores, mesmo considerando que para análise marxista, o processo de trabalho e o processo de valorização tem no incremento da intensificação um fundamento do trabalho assalariado desde a constituição do capital como forma predominante de produção social. Desse modo, constatamos como a principal lacuna da intepretação marxista clássica a ausência temática acerca da sobrecarga ou intensificação no processo de trabalho das ocupações em saúde. Atualmente, esses aspectos associados às formas contemporâneas de precarização de vínculo são o principal vínculo entre o processo de trabalho das ocupações em saúde e o regime de acumulação.

Como vimos, a inserção no mercado de trabalho do profissional médico é a primeira temática central da interpretação marxista e o consequente diagnóstico da tendência de assalariamento e o aprofundamento da heterogeneidade dos profissionais (Donnangelo, 1975 e Schraiber, 1993). Do ponto de vista da organização contemporânea 
do trabalho, o emprego se insere em nova composição da relação salarial (Castel, 1998) alterada devido ao esgotamento relativo do fordismo como forma produtiva dominante da acumulação do capital no capitalismo central. Consequentemente, para o mercado de trabalho, houve o crescimento do desemprego de longa duração e do trabalho parcial e temporário sem os direitos do período anterior existentes.

Esses aspectos inseridos no processo de proletarização peculiar da categoria médica servirá como parâmetro de entendimento das características flexíveis dos vínculos de trabalho desses profissionais e das demais ocupações em saúde na atualidade. Na dinâmica contemporânea, a heterogeneidade amplia-se em diversas esferas, inclusive, na flexibilização de regimes de trabalho e na conformação de regimes de trabalho sem qualquer vínculo ou regulação pública nos termos trabalhistas, embora se mantenha o vínculo corporativo com o conselho de classe. Muito além da transição para o assalariamento característico do fordismo, o desmonte do emprego permanente e estável é apresentada enquanto tendência da organização contemporânea do trabalho para os profissionais de saúde ${ }^{108}$. Essa instabilidade não é referente somente a salários, mas também a outros benefícios e direitos., a flexibilização é a tendência geral, a reforma trabalhista aprovada em 2017 contém esses elementos e podem nortear as relações de emprego no próximo período das ocupações em saúde. Recentemente, a modalidade de contratação por serviço denominado como a "uberização" também se espalha em diversos segmentos (Abilio e Machado, 2017).

Aliás, a relação contemporânea de oferta de serviços ou propriamente da prestação de serviços através de aplicativos é uma mudança significativa da contemporaneidade do trabalho. O trabalhador e "prestador" de serviços mais típico é motorista de viagens particulares da empresa mundial "Uber", porém, essas formas ampliam-se para diversos segmentos inclusive os considerados qualificados. Nos profissionais de saúde, observa que para determinados segmentos embora não seja a forma exclusiva, é a forma complementar de obtenção de renda. Poderíamos denominar que a uberização já tem sido

\footnotetext{
108 Por exemplo, a prática comum dos empregadores do setor privado da contratualização "pejotista" e das contratações temporárias na administração pública (Souza e Mendes, 2016). Existe amplo repertório de medidas de flexibilização de vínculos trabalhistas, apesar de não estar nítido quais serão os instrumentos utilizados: cooperativismo, trabalho parcial e temporário , contrato por agência de emprego ou agency labour, contratação temporária por projetos e programas, "pejotismo" etc..
} 
um aspecto configurador do trabalho e cumpre aspectos no gerenciamento, controle e organização do trabalho. Por exemplo, a incorporação das tecnologias de informação e comunicação é muito mais incisiva na influência do trabalho relacionada a esse processo, sendo que a maior consequência é a total disposição dos profissionais ao emprego, justamente pela facilidade de comunicação por aplicativos de mensagens instantâneas direto com os usuários dos serviços (as diversas propostas de avaliação dos usuários sobre os procedimentos são exatamente a mesma forma avaliativa dos aplicativos).

Para além da mudança de não vinculo de trabalho, a generalização da lógica da terceirização se consolidou nos serviços de saúde. O trabalho sem vínculo empregatício elimina as convenções de terceirização convencional e as complementa. A análise do vínculo empregatício é determinante para o entendimento da conformação dos regimes de trabalho dos profissionais nos serviços de saúde, entendidos na acepção ampla de relações de poder no local de trabalho (Burawoy, 1990). Desse modo, o tipo de contrato ou da inserção profissional no mercado de trabalho é fundamento de questões como: autonomia, mercado interno de trabalho (promoção, transferências, demissão), remuneração, ação coletiva entre outros.

No caso dos profissionais médicos, a análise deve considerar os elementos de particularidades, pois existe uma gradação atenuante da tendência geral por sua proletarização peculiar. Contudo, assim como outros setores do mercado de trabalho nacional, as tendências gerais da organização e os regimes de trabalho os impactam de forma diferenciada, se por um lado, ainda persiste a escassez de profissionais que possibilitam maior poder de mercado e o predomínio do diagnóstico e terapêutica sobre outros profissionais. Por outro lado, a generalização de formas flexíveis diminui a estabilidade ou configura a relação salarial de combinação de diversos tipos de trabalho para parcelas da categoria médica. Em relação aos demais profissionais de saúde que não tem a mesma posição de mercado, a tendência de fim de emprego permanente é ainda mais agressiva. Por exemplo, constata-se que a realidade de emprego e de sua precariedade de outros profissionais de saúde, sobretudo, profissionais de nível médio.

A interpretação de que a intensificação e precarização dos vínculos de trabalho para o conjunto dos trabalhadores médicos ou das demais ocupações em saúde aproximadamente dois milhões de empregos no Brasil (Machado, 2011) seria incipiente, decerto o trabalho e trabalhadores comportam heterogeneidades, disparidade em todos os 
aspectos da realidade de diferentes segmentos das frações da classe trabalhadora até segmentos profissionais associados ao capital pelo "hibridismo profissional" (alta qualificação e/ou empresariamento). 


\section{CONSIDERAÇÕES FINAIS}

A interpretação marxista clássica do trabalho do saúde como construtores da saúde coletiva ancora-se em referencial teórico plural, logo, realiza associação pluriparadigmática de três postulados distintos críticos da modernidade: a epistemologia histórica nas definições dos estados normal e patológico para a crítica das práticas de saúde (Canguillem, 2009); a historiografia da medicina social (Foucault, 2003) e a mercantilização da vida social e a crítica à sociedade capitalista inspirada em Marx. Essa associação teórica, embora, eclética do ponto de vista epistemológico é consideravelmente fértil nas mediações estabelecidas pelos autores e sobretudo nos objetos de seus estudos.

No desenvolvimento teórico dessas associações, os autores realizam mediações, por exemplo, transitam os elementos da epistemologia histórica de Canguillem à análise de situações concretas nas práticas de saúde de forma crítica. Do mesmo modo, incorporam reflexões e teses dos meios intelectuais, italianos e franceses na década de 1960, logo, a recepção de Foucault em parte é realizada pelas elaborações dos marxistas franceses, Polack (1972) e Boltansky (1979), no entendimento da disciplina sobre o corpo na estrutura produtiva e da generalização e do declínio da clínica. Do ambiente intelectual italiano, as produções de Conti e Berlinguer são decisivas para a crítica da técnica na medicina e da historicidade das práticas, assim como, na determinação social do processo saúde-doença. À primeira vista, tal diagnóstico pode parecer uma constatação que as produções teóricas dos autores abordados não seriam originais, ao contrário, a síntese de diversos paradigmas de teorias sociais na relação social em saúde e do referencial teórico marxista ocorreu na produção brasileira, inclusive, porque o diálogo entre a produção francesa e italiana era escasso no período assinalado.

No curso dessas incorporações, advogamos que duas teses fundamentais da Escola de Frankfurt são decisivas para a construção da teoria social em saúde: a crítica a supremacia da racionalidade técnica de Adorno e Horkheimer (1996) e a crítica a Ideologia do Progresso de Walter Benjamim (1987), apesar da influência ocorrer pela mediação de outros autores, sendo Conti responsável pelo desenvolvimento da crítica a ideologia do progresso na história tradicional da medicina e Illich (1975) responsável pelo desvelamento da crítica à racionalidade na saúde contemporânea, com conteúdo próximo à caracterização da racionalidade instrumental. 
A riqueza dessa teoria formulada tem como pressuposto o entendimento crítico do caráter da modernidade capitalista implicitamente. Desenvolve as contraditoriedades vinculadas ao domínio racional da natureza corpórea e seu meio, situação na qual se agudizam os contrastes entre as possibilidades e (não) realizações do progresso técnico, cientifico e tecnológico e as condições de vida das classes sociais no capitalismo. Desse modo, essa abordagem sobre a modernidade, especificamente, como a consolidação da ordem burguesa, transforma totalmente a relação com a natureza e é chave fundamental para uma série de transformações produtivas e da própria vida social, inclusive, na relação com o corpo, aspecto basilar para as associações das teorias críticas.

Nesse sentido, explicitamos que a categoria medicalização utilizadas pela interpretação marxista clássica, embora tenha ganhado contornos polissêmicos, trata-se de uma categoria em referência ao processo histórico da modernidade social e interpretada por paradigmas críticos. Em síntese, três concepções de medicalização estão presentes nas obras estudadas: 1- Em Foucault, corresponde a três dimensões integradas: a generalização da clínica através das formas de medicina social desenvolvidas pelos estados na Europa ocidental; a concentração do saber nos profissionais médicos em relação aos demais indivíduos; e a tecnologia disciplinar sobre o controle dos corpos, o biopoder; 2- Illich analisa os aspectos contemporâneos da relação social de saúde após a consolidação da medicalização como uma racionalidade estabelecida, em especial, os efeitos deletérios sobre a autonomia do indivíduo que perde seu direito de escolha e está submetido às iatrogênese clínica e social; 3- Na acepção de inspiração marxista, o domínio racional sobre o corpo porta as contradições da relação homem com a natureza na modernidade capitalista, sinteticamente, se o homem consegue alterar o curso do orgânico ou psíquico no sentido de vida, morte ou sofrimento pela sua intencionalidade. Também é verdade que essa capacidade sistematizada pela racionalidade técnica instrumental na sociabilidade capitalista carrega os aspectos regressivos e desumanizadores.

No horizonte estabelecido, essas contradições inerentes à medicalização significam que a maior capacidade de intervenção humana sobre o corpo, no sentido de sua reconstituição/normalização também é uma ação social de domínio político entre indivíduos e classes. Sendo assim, a intervenção técnica, as práticas em saúde, balizada 
pela normatividade vital são pautadas pela racionalidade técnica instrumental na sociabilidade capitalista. Desse modo, a exemplo da concepção de história de Benjamin (1987), seria possível indicar que o complexo das relações sociais denominadas como medicalização podem ser interpretadas enquanto "monumento da cultura e da barbárie humana", contraditoriamente, por um lado, capaz de feitos humanos notáveis, por outro, do desenvolvimento de relações desumanizadoras. Justamente, a crítica à apologia do progresso em saúde problematiza a tendência histórica da legitimação do maior número de intervenções, medicamentos e técnicas ou mesmo de orçamentos para essas medidas que não necessariamente geram relações emancipadas. Ainda que de modo incipiente, os autores da interpretação marxista clássica buscam a síntese das três acepções se amparando no fundamento metodológico da totalidade histórica para apreciação de situações concretas. Dessa maneira, a dedicação majoritária da interpretação marxista pelo trabalho médico, figura expoente do processo de medicalização moderna, tem fundamento nas diversas acepções e procura entender como a sociabilidade capitalista no trabalho se vincula à medicalização da vida social.

Se por um lado, a formação técnica científica demonstra sucesso nas intervenções sobre a natureza, e especificamente, na relação da intervenção em saúde sob o corpo na dimensão vital do indivíduo, por outro lado, o pressuposto da formação sob a racionalidade técnica instrumental é um dos principais elementos de alienação dos indivíduos no trabalho em saúde. Nesse sentido, o conjunto das ocupações em saúde são alicerçadas em tal racionalidade inserida no paradigma biomédico de ordem positivista, logo, a ação dos indivíduos e do trabalho em saúde estão forjados sob a marcha do progresso presente na concepção de "dobrar a natureza" (Canguillem, 2009) conforme sua intencionalidade, muitas vezes, desconsiderando as iatrogênias. Embora, o estatuto diferenciado do médico sobre outras ocupações capitalistas na modernidade seja relevante pelo seu predomínio das relações de saúde e doença, a racionalidade instrumental em saúde se amplia na constituição do do conjunto das profissões independente do estatuto conferido na constituição moderna, atingindo inclusive as profissões historicamente proletarizadas.

Referente as principais contribuições da interpretação marxista clássica frisamos que o conjunto dos autores abordam a transição do oficio liberal da medicina para o assalariamento promovido pela medicina tecnológica empresarial no regime de acumulação do capital monopolista. Os autores elaboram diante da tendência de 
destituição do exercício liberal da medicina devido às formas de transição da política estatal de saúde, a organização da produção dos serviços de saúde e do mercado. Da mesma maneira, diagnosticam o aumento da complexificação do trabalho em saúde.

Nesse processo, a articulação da medicina com a sociedade teria fundamento no trabalho médico. Em Arouca, o cuidado é o ponto de partida do processo de trabalho do destacando a natureza relacional entre o médico e o paciente. Em sua apreciação, esse cuidado configuraria uma mercadoria cujo o valor de uso, seria a intervenção sobre as necessidades humanas vitais. Todavia essa relação do cuidado estava inserida na relação social do valor e o médico também seria um intermediário da relação de troca de mercadorias da indústria

O horizonte de Donnangelo $(1975,1976)$ desvelou os princípios da medicina enquanto prática histórico-social e desmitificou o predomínio da técnica e a ciência. Desse modo, o objeto da medicina seria externo a ela e seria forjado na estrutura econômica e política das sociedades. Donnangelo também ressalta que as inovações nas técnicas de produção, diversificação e a ampliação dos meios de trabalho, fornecem as bases para o solapamento progressivo dessa forma de organização, ao reduzirem as possibilidades de controle e constituem a heterogeneidade da inserção dos médicos no mercado de trabalho pela oscilação entre os polos de assalariamento e a autonomia por exercício liberal ou empresarial. Schraiber (1993) realiza o estudo da integralidade do trabalho médico e a centralidade a partir do depoimentos e trajetórias de vida dos profissionais e ressalta como a centralidade da autonomia para a profissão médica se mantém mesmo com o incremento da especialização da incorporação de capital expressos nas tecnologias de diversas ordens.

Em Mendes-Gonçalves (2017) temos uma "virada" no âmbito teórico e de pesquisa. $\mathrm{O}$ autor, alicerçado na teoria marxista, vinculou o pressuposto filosófico da ontologia do trabalho como constituidor do humano na relação de modificação da natureza na relação com a saúde Do ponto de vista de objeto, altera o estudo histórico da prática médica nas sociedades capitalistas medicalizadas para uma amplitude temática sobre o trabalho coletivo em saúde e desenvolve a reflexão entre a correspondência entre processos de trabalho e necessidades em saúde e da proposição da acepção ampla da categoria tecnologia. Mendes-Gonçalves (2017), sem prescrever modelos “ideais”, aposta em novos processos de trabalhos conectados com as necessidades radicais em saúde com 
o propósito de mudança social. As combinações desses processos têm a potencialidade de corresponder às necessidades em saúde conformadas sócio historicamente por meio das práxis coletivas.

No tocante às diferenças entre os autores, ressaltamos a divergência acerca do possível papel cumprido pelo Estado no Brasil. Enquanto Donnangelo ressalta o papel de fomentador dos serviços privados em saúde, Arouca aposta na desvinculação do Estado da formação capitalista para propiciar forma progressiva de trabalho e serviços em saúde. A mesma ordem de diferença aparece sob a análise da técnica, isto porque, enquanto Donnangelo apresenta a crítica ao seu caráter social, Arouca acredita que a técnica pode cumprir um papel progressivo no sentido do desenvolvimento das forças produtivas e sua possível socialização.

Acerca do balanço crítico nos temas específicos do trabalho em saúde, referente a transição do assalariamento dos médicos, por entender que o assalariamento se vincula ao processo histórico mais amplo, desenvolvemos a caracterização de proletarização peculiar dos profissionais médicos vinculados a organização do trabalho fordista. Justamente, pela concentração analítica no assalariamento e no estudo da prática médica, a principal lacuna da intepretação marxista clássica é a ausência temática acerca da sobrecarga ou intensificação no processo de trabalho das ocupações em saúde. Embora a ausência deva ser relativizada, pois o nível de intensidade sobre os profissionais na década de 1970 não se assemelhasse ao presenciado na forma contemporânea de organização do trabalho toyotista nos serviços de saúde. Contudo, a respeito da categoria médica, provavelmente o movimento de assalariamento pela organização capitalista em saúde já apontava elementos de intensificação, assim como, os demais profissionais de saúde conviviam com formas de exploração e precariedade das condições de trabalho características da formação social brasileira, assim como, não se aborda aspectos vinculados aos conflitos no local de trabalho e a ação coletiva desses trabalhadores.

Por fim, defendemos a pertinência da interseção entre os processos sociais da mercantilização e da medicalização para apreensão das relações e sobre trabalho em saúde na sua forma contemporânea. Para tal tarefa é necessário superar a antinomia tipológica de antinomia entre trabalho produtivo e improdutivo na caracterização geral do trabalho em saúde. Nesse sentido, a forma social do valor em saúde no regime de acumulação flexível está vinculada com as formas abundantes de medicalização, no âmbito do 
trabalho, da intensificação do processo de trabalho e da precariedade de vínculos de emprego. Todos esses aspectos constituem principal indicio da relação do processo de trabalho social imbricado com a relação de valor. 


\section{REFERÊNCIAS}

ABILIO, L. C. ; MACHADO, R. . Uberização traz ao debate a relação entre precarização do trabalho e tecnologia. IHU ON-LINE (UNISINOS. IMPRESSO), v. 01, p. 20-28, 2017.

ABRASCO. Anais do $6^{\circ}$ Congresso Brasileiro de Ciências Sociais e Humanas em Saúde. Circulação e Diálogo entre saberes e práticas no campo da Saúde Coletiva. Rio de Janeiro, 2013.

. Anais do II Congresso Brasileiro de Política, Planejamento e Gestão em Saúde: Estado e Democracia. O SUS como direito social, Belo Horizonte, 2013.

. Anais do $7^{\circ}$ Congresso Brasileiro de Ciências Sociais e Humanas em Saúde.

Pensamento Crítico, Emancipação e Alteridade: Agir em Saúde na (ad)diversidade. Cuiabá, 2016.

Anais do III Congresso Brasileiro de Política, Planejamento e Gestão em Saúde: Estado e Democracia. O SUS como direito social, Natal, 2017.

ADORNO, Theodor W, HORKHEIMER, Max. A dialética do esclarecimento. Rio de Janeiro: Jorge Zahar Editor,1995.

ALTHUSSER, L. Sobre la relacion de Marx com Hegel. In: Escritos I. Bogotá, Ediciones Contacto, 1971.

ALMEIDA, P. V. B., \& ZANOLli, M. L. O Papel do Pediatra no PSF-Paidéia de Campinas (SP). Ciência \& Saúde Coletiva, 16(Suplemento 1), 9, 2011

ALMEIDA MCP, ROCHA JSY. O saber de enfermagem e sua dimensão prática. São Paulo: Cortez; 1986.

ALMEIDA MCP, ROCHA SMM. O trabalho de enfermagem. São Paulo: Cortez; 1997. AMÂNCIO FILHO, A. MOREIRA CGB (Org.) Saúde, trabalho e formação profissional. Rio de Janeiro: FIOCRUZ, 1997 
ANDERSON, Perry. Considerações sobre o marxismo ocidental. 2.ed. São Paulo: Brasiliense, 1989

AROUCA, S. O dilema preventivista: Contribuição para a compreensão e crítica da medicina preventiva. Rio de Janeiro, Editora Fiocruz/Unesp.2003

A.T. Arouca e S. Arouca. "Medicina de comunidade: implicações de uma teoria" . Revista Saúde em Debate do CEBES, Vol 1, 1976. Disponível em: http://www.docvirt.com/asp/saudeemdebate/default.asp

AYRES, JRCM. Teoria do trabalho e construção de conhecimento em saúde coletiva: para uma epistemologia reconstruída como práxis emancipadora. Divulgação em saúde para debate. CEBES, Londrina, 1996

Do processo de trabalho em saúde à dialógica do cuidado: repensando conceitos e práticas em saúde coletiva. São Paulo, 2002. Tese (Livre Docência) Faculdade de Medicina, Universidade de São Paulo.

- Ricardo Bruno: história, processos sociais e práticas de saúde. Ciênc. saúde coletiva, Rio de Janeiro , v. 20, n. 3, p. 905-912, Mar. 2015 Available from <http://www.scielo.br/scielo.php?script=sci_arttext\&pid=S1413$81232015000300905 \& \operatorname{lng}=$ en\&nrm=iso $>$. access

on 13 Aug. 2018. http://dx.doi.org/10.1590/1413-81232015203.00112015.

Georges Canguilhem e a construção do campo da Saúde Coletiva Brasileira. Intelligere, Revista de História Intelectual. - v. 2, n. 1 [2], 2016

ARENDT, H. A condição humana. Trad. Roberto Raposo. Rio de Janeiro: Forense Universitária, 2001.

AUGUSTO, MHO. Natural, Racional, Social: Discussão de uma sociabilidade. Tempo Social. Rev. Sociol. USP, São Paulo 1 (I): 247-257, 1 sem, 1989.

BACON, F. Os pensadores. São Paulo: Nova Cultura, 1999,

BASSO, L. apud MARCUSE, H. Contra-revolução e revolta. Rio de Janeiro, Zahar, 1973. 
BENJAMIN, W.- Teses sobre o conceito da história In Obras escolhidas. Vol. 1. Magia e técnica, arte e política. Ensaios sobre literatura e história da cultura. Trad. Sérgio Paulo Rouanet. São Paulo: Brasiliense, 1987, p. 222-232.

Berlinguer. Introducción. IN MEDICINA Y SOCIEDAD (org) Aloisi et al. Libros de Confrontacion-Editorial: Fontanella, Barcelona, 1972

BOURDIEU, P. Razões Práticas: sobre a teoria da ação. Campinas, Papirus Editora, 2008 BOLTANSKY, L. As classes sociais e o corpo. Rio de Janeiro: Edições Graal, 1979.

BRASIL. Constituição da República Federativa do Brasil. Disponível em: http://www.planalto.gov.br/ccivil_03/Constituicao/Constituicao.htm

Lei de Responsabilidade Fiscal. Lei complementar $n^{\circ} 101$, de 4 de maio de 2000. Estabelece normas de finanças públicas voltadas para a responsabilidade na gestão fiscal e dá outras providências. Disponível em: https://www.planalto.gov.br/ccivil_03/leis/lcp/lcp101.htm. Acesso em: 26 nov. 2013.

BRAVERMAN, H. Trabalho e Capital monopolista. Rio de Janeiro, Zahar. Edição original, 1987.

BRESSER-PEREIRA LC. A reforma gerencial do Estado de 1995. Revista de Administração Pública, 2000. 34 (4):55-72.

BRANT, L.C.; CARVALHO, T.R.F. Metilfenidato: medicamento gadget da contemporaneidade. Interface - Comunic., Saude, Educ., v.16, n.42, p.623-36, jul./set. 2012.

BURAWOY, M. A transformação dos regimes fabris no capitalismo avançado. Revista Brasileira de Ciências Sociais.n²13.ANPOCS: 1990

The Extended Case Method: Four Countries, Four Decades, Four Great Transformations and One Theoretical Tradition. University of California Press. 2009.

CAMARGO JR., K.. Racionalidades médicas: a medicina ocidental contemporânea. Rio de Janeiro: IMS-UERJ, 1993 (Série Estudos em Saúde Coletiva, 65). 
. "As armadilhas da concepção positiva de saúde", Physis: Revista

de Saúde Coletiva, 17, 1 (2007)

CAMPOS, G. W. S. Subjetividade e administração de pessoal: considerações sobre modos de gerenciar o trabalho em equipes de saúde. In E. E. Mehry \& R. T. O. Campos (Eds.), Agir em saúde: um desafio para o público. (pp. 229-266). São Paulo: Hucitec, 1997

O Anti-Taylor: sobre a invenção de um Método para co-governar instituições de saúde produzindo liberdade e compromisso. Cadernos de Saúde Pública (FIOCRUZ), v. 14, n. 4, p. 863-870, 1998.

Equipes de referência e apoio especializado matricial: um ensaio sobre a reorganização do trabalho em saúde. Ciência \& Saúde Coletiva, 4(1), 9, 1999.

. Saúde Paidéia. São Paulo: Editora Hucitec, 2003.

Cogestão e neoartesanato: elementos conceituais para repensar o trabalho em saúde combinando responsabilidade e autonomia. Ciência \& Saúde Coletiva, 15(5), 7, 2010.

CAMPOS, GWS; AMARAL, MA. A clínica ampliada e compartilhada, a gestão democrática e redes de atenção como referenciais teórico-operacionais para a reforma do hospital. Ciênc. saúde coletiva, Rio de Janeiro, v. 12, n. 4, p. 849-859, Aug. 2007 . Available from <http://www.scielo.br/scielo.php?script=sci_arttext\&pid=S141381232007000400007\&lng=en\&nrm=iso>. access on 18 Jan. 2017. http://dx.doi.org/10.1590/S1413-81232007000400007.

CANGUILHEM, Georges. O normal e o patológico. Trad. Maria Thereza R. C. Barrocas. 6. ed. rev. Rio de Janeiro: Forense Universitária, 2009

CARVAlHO, G. A saúde pública no Brasil. Estud. av., São Paulo , v. 27, n. 78, p. 726, 2013 . Available from $<$ http://www.scielo.br/scielo.php?script=sci_arttext\&pid=S010340142013000200002\&lng=en\&nrm=iso $>$ access on $17 \quad$ Sept. 2018. http://dx.doi.org/10.1590/S0103-40142013000200002. 
CARVALHO, José Murilo de. Cidadania no Brasil. O longo Caminho. $3^{\mathrm{a}}$ ed. Rio de Janeiro: Civilização Brasileira, 2002.

CASTRO, P. Sociologia do trabalho (Clássica e Contemporânea).Niterói: EdUFF,2003. $242 \mathrm{p}$.

CASTELlANOS, M.E.P; LOYOLA, M.A, IRIART, J.A.B. Ciências Sociais em Saúde Coletiva. In. PAIM, J.S; ALMEIDA-FILHO, N. (org.). Saúde Coletiva-Teoria e Prática. 01 ed. Rio de Janeiro: MedBook Editora Científica Ltda, 2013

CASTEL, R . As metamorfoses da questão social: uma crônica do salário. Petrópolis: Vozes, 1998.

CECILIO, LCO; LACAZ, FAC. O trabalho em saúde Rio de Janeiro: Cebes, 2012

CECILIO, L. C. O.; MENDES, Taniella Carvalho . Propostas alternativas de gestão e o protagonismo dos trabalhadores: por que as coisas nem sempre acontecem como os dirigentes desejam?. Saúde e Sociedade (USP. Impresso), São Paulo, v. 13, n.2, p. 39$55,2004$.

CECILIO, L. C. O. . Escolhas para inovarmos na produção do cuidado, das práticas e do conhecimento: como não fazermos "mais do mesmo". Saúde e Sociedade (USP. Impresso), v. 21, p. 280-289, 2012.

CECILIO, L. C. O. Inventando a mudança na saúde. São Paulo: HUCITEC, 1994. 334p .

CECILIO, L. C. O. . Autonomia versus controle dos trabalhadores: a gestão do poder no hospital. Ciência \& Saúde Coletiva , Rio de Janeiro, v. 4, n.2, p. 315-329, 1999.

CECÍLIO LCO. As necessidades de saúde como conceito estruturante na luta pela integralidade e equidade na atenção em saúde. In: Os sentidos da integralidade na atenção e no cuidado à saúde / Roseni Pinheiro e Ruben Araújo de Mattos, organizadores. 6. ed. Rio de Janeiro: IMS/UERJ - CEPESC - ABRASCO, 2006. 180p. Disponível em: http://www.uff.br/pgs2/textos/Integralidade_e_Equidade_na_Atencao_a_saide_-

_Prof_Dr_Luiz_Cecilio.pdf

CANGUILHEM, G. O Normal e o Patológico. Editora Forense Universitária, Rio de Janeiro: 2009 
CASTIEL, L. D. Vivendo entre exposições e agravos: a teoria da relatividade do risco. A medida do possível - saúde, risco e tecnobiociências. Rio de Janeiro: Editora, 1999. Disponível em: <http://www.ensp.fiocruz.br/projetos/esterisco/inicio1.htm>

CHIAVEGATO, L.G e NAVARRO, V.L.A Organização do Trabalho Em Saúde em um Contexto de Precarização e do Avanço da Ideologia Gerencialista. Revista Pegada, v. 13 n.2, Dezembro-2012.

COELHO, M. T. A. D.; ALMEIDA E F. N. . "Normal-patológico, saúde-doença: revisitando Canguilhem”, Physis: Revista de Saúde Coletiva, 9, 1 (1999): 13-36

COFEN/FIOCRUZ. MACHADO, M H (Coord.). Perfil da enfermagem no Brasil: relatório final: Brasil / coordenado por Maria Helena Machado. - Rio de Janeiro : NERHUS - DAPS - ENSP/Fiocruz, 2017. 748 p.

COHN, A. e DONNANGElO, M. C. F. - Condições do exercício profissional da medicina na área metropolitana de São Paulo, Cruesp, FMUSP, 1983, (mimeo).

CONTI, L. Estructura Social y Medicina. IN MEDICINA Y SOCIEDAD (org) Aloisi et al. Libros de Confrontacion-Editorial: Fontanella, Barcelona, 1972, pp. 287-310

CORDEIRO, Hésio. A Indústria de saúde no Brasil. Rio de Janeiro, Graal, 1980. 229p

Domitrovic, N. \& Caliman, L. V. As controvérsias sócio-históricas das práticas farmacológicas com o metilfenidato. Psicologia \& Sociedade, 29, e163163, 2017.

DONNANGELO, M. C. Medicina e sociedade (o médico e seu mercado de trabalho).São Paulo: Pioneira 1975.

DONNANGELO, M. C e PEREIRA, L. Saúde e Sociedade. São Paulo, Livraria Duas Cidades. 1976

DURAND, J-P. A refundação do trabalho no fluxo tensionado. IN: Revista Tempo Social. v.15, n.1.São Paulo Abril/2003.

EMERENCIANO, C B. As raízes do pensamento econômico em saúde no Brasil: a concepção do "trabalho médico e a produção" na obra o dilema preventivista de Sérgio Arouca. Curitiba, 2017.139 f. 
ENGELS, Friedrich. A Situação da classe trabalhadora na Inglaterra. São Paulo: Boi tempo, 2008.

Fernandes F. Sociedade de classes e subdesenvolvimento. São Paulo: Global Editora; 2008.

FOUCAULT, M. O Nascimento da Clínica. Rio de Janeiro. Editora ForenseUniversitaria, 1977

. Vigiar e Punir: nascimento da prisão. Trad. Lígia M. Ponde Vassalo. Petrópolis: Vozes, 1987.

Introdução a uma vida não fascista. In: Deleuze, G. e Guattari, F. Anti-Edipus: capitalism and schizophrenia. Minneapolis: University of Minnesota Press, 2000. Disponível em: http://michelfoucault.weebly.com/uploads/1/3/2/1/13213792/vidanaofascista.pdf .Microfísica do poder. Rio de Janeiro: Graal, 2002. As palavras e as coisas: uma arqueologia das ciências humanas. Trad. Salma Tannus Muchail. 9. ed. São Paulo: Martins Fontes, 2007. , "A vida: a experiência e a ciência”, em M. Foucault, Arqueologia das ciências e história dos sistemas de pensamento (Rio de Janeiro: Forense Universitária, 2008) 352-366 (Ditos e Escritos II), 353. . Nascimento da biopolítica. Curso dado no Collège de France (1978-1979). São Paulo: Martins Fontes, 2008b . O governo de si e dos outros. Curso dado no Collège de France (19821983). São Paulo: Martins Fontes, 2010.

FLEURY, S. Giovanni Berlinguer: socialista, sanitarista, humanista!. Ciênc. saúde coletiva, Rio de Janeiro , v. 20, n. 11, p. 3553-3559, Nov. 2015

FREIDSON, E. Profissão médica. Um estudo de sociologia do conhecimento aplicado. São Paulo, Editora Unesp, 2009

FRIEDMANN, G. Sete estudos sobre o homem e a técnica. São Paulo: Difusão Europeia do Livro, 1968 
FRIEDMANN, G.; NAVILLE, P. Prefácio. In: FRIEDMANN, G.; NAVILLE, P. (Org.). Tratado de sociologia do trabalho. São Paulo: Cultrix, 1973. v.2, p. 13-15.

GAJARDO, M. Ensaio In Ivan Illich. Recife: Fundação Joaquim Nabuco, Editora Massangana, 2010. 150 p.: il. - (Coleção Educadores)

GIANOTTI, J. A. O ardil do trabalho. São Paulo: Estudos Cebrap 04, 1973.

GIROTTI, MT. A Crítica de Hegel ao dualismo Sujeito-Objeto de Kant. Rev. SimbioLogias, V.3, n.4, Junho/2010.

GOMES, R. M. As mudanças no mundo do trabalho e a qualificação do trabalho em saúde. 2007. Dissertação, Programa de Pós-Graduação em Educação - Área Educação e Trabalho, Setor de Educação, Universidade Federal do Paraná, Curitiba.

GOMES, R. M. Trabalho médico e alienação: as transformações das práticas médicas e suas implicações para os processos de humanização/desumanização do trabalho em saúde. [Teses de Doutorado]. Universidade de São Paulo, São Paulo, 2010.

GOMES, R. M. Humanização e desumanização no trabalho em saúde: algumas contribuições conceituais para uma análise crítica. In NOGUEIRA, R. P e GOMES, R. M. Capitalismo e Saúde. Rio de Janeiro: CEBES, 2012.

GRAMSCI, A. Os Intelectuais e a Organização da Cultura. Trad. de Carlos Nelson Coutinho. 4. ed. Rio de Janeiro: Civilização Brasileira, 1982.

Americanismo e Fordismo. São Paulo: Hedra, 2008.

Cadernos do Cárcere - Volume 1: Introdução ao estudo da filosofia- a

filosofia de Benedito Croce. 5 ed. Rio de Janeiro: Civilização Brasileira, 2011

HABERMAS, J. Mudança estrutural da esfera pública: investigações quanto a uma categoria da sociedade burguesa. Rio de Janeiro: Edições Tempo Brasileiro, 1984.

.Consciência Moral e Agir Comunicativo. Tempo Brasileiro, Rio de Janeiro. 1989

Técnica e Ciência como Ideologia. Edições 70, Lisboa. 1994 
O Discurso Filosófico da Modernidade, São Paulo, Livraria Martins Fontes Editora LTDA. 2000.

HARVEY, D.. Condição Pós-Moderna. 13 ed. São Paulo: Edições Loyola. 2004 .Para compreender o Capital. Editora Boitempo. São Paulo, 2013.

HELLER, A. Teoría de las necesidades en Marx. Barcelona: Península, 2 ed. 1986.

HOCHMAN, G; NUNES, E. D. Apresentação de uma Nova Seção na RC\&SC: Construtores da Saúde Coletiva. Ciênc. saúde coletiva, Rio de Janeiro, v. 20, n. 1, p. 137, Jan. 2015 . Available from $<$ http://www.scielo.br/scielo.php?script=sci_arttext\&pid=S141381232015000100137\&lng=en\&nrm=iso>. access on $04 \quad$ June 2019. http://dx.doi.org/10.1590/1413-81232014201.00202014.

HOLANDA,. Sergio Buarque. Raízes do Brasil. Companhia das Letras, Edição comemorativa. 70 anos. 2006

IANNI et all, Democracia Radical en Brasil: el pensamiento crítico em Salud Colectiva (1970-1980). Congresso da ALAMES, 2016

ILLICH, I. Une société sans école. Paris: Seuil, 1971 La convivialité. Paris: Seuil, 1973

A Expropriação da Saúde Nêmesis da Medicina 3. ${ }^{a}$ Edição. Editora: Nova Fronteira, 1975.

IANNI, A. O campo temático das ciências sociais em saúde no Brasil. Tempo Social, revista de sociologia da USP, v. 27, n. 1, 2015.

THOMPSON, EP- A Miséria da Teoria ou Um Planetário De Erros: uma crítica ao pensamento de Althusser. Zahar Editores, Rio de Janeiro, 1981

LAURELL, A. C. A saúde-doença como processo social. In: NUNES, E. D. (Org.). Medicina social: aspectos históricos e teóricos. São Paulo: Global, 1983. p. 133-158.

LARSON, Magali Sarfatti.. Proletarianization and educated labor. Theory and Society, v. 9, n. 1, p.131-

175, jan. 1980. Disponível em: <goo.gl/EMYP8h>. Acesso em: 25 jan. 2014 
LACAZ, F. A. C., 1983. Saúde no Trabalho. Dissertação de Mestrado, São Paulo: Faculdade de Medicina, Universidade de São Paulo

LACAZ, F.A.C.. Saúde do trabalhador: um estudo sobre as formações discursivas da academia dos serviços e do movimento sindical. 1996. 432 f. Tese (doutorado) Universidade Estadual de Campinas, Faculdade de Ciências Médicas, Campinas, SP. Disponível em: <http://www.repositorio.unicamp.br/handle/REPOSIP/313672>. Acesso em: 22 jul. 2018

LEAVELL, H. \& CLARK, E. G. (1965), Preventive medicine for the doctor in his community. Nova York, McGraw-Hill.

LIPIETZ, A. Fordismo, fordismo periférico e metropolização. Ensaios FEE, Porto Alegre, 10 (2): 285-302, 1989.

. O Mundo do Pós Fordismo. . Ensaios FEE, Porto Alegre, 24,(4) 1997 79130,1997

Li Sun \& Tao Liu (2016) Occupational diseases and migrant workers' compensation claiming in China: an unheeded social risk in asymmetrical employment relationships, Health Sociology Review, 25:1, 122-136, DOI: 10.1080/14461242.2015.1099113

LOWY, M. A Dialética Marxista do Progresso. In: BENSAÏD, D.; LÖWY, M. Marxismo, Modernidade e Utopia. São Paulo: Xamã, 2000. p.58-67

A Teoria da Revolução no Jovem Marx. Petropólis: Vozes, 2002.

LUZ, M. T. Natural, racional, social: razão médica e racionalidade científica moderna. 2. ed. São Paulo: Hucitec, 2004. 209 p

LUKÁCS, G. Para uma ontologia do ser social I. São Paulo: Boitempo, 2012 Para uma ontologia do ser social II. São Paulo: Boitempo, 2014

LUKÁCS, G. Tecnologia e debate com Bukharin

MACHADO, Roberto. Ciencia e Saber: a trajetória da arqueologia de Michel Foucault. Rio de Janeiro: Edições Graal, 1981.

MACHADO, MH. Profissões de Saúde: Uma abordagem sociológica. Rio de Janeiro, FIOCRUZ, 1995. 
MACHADO, MH et al. Perfil dos médicos no Brasil: Análise Preliminar. Rio de Janeiro, FIOCRUZ, 1996

MACHADO, MH., coord. CARACTERÍSTICAS SOCIOLÓGICAS DA PROFISSÃO MÉDICA In. Os médicos no Brasil: um retrato da realidade. [online]. Rio de Janeiro: Editora FIOCRUZ, 1997. 244 p. ISBN: 85-85471-05-0.

MACHADO, M.H. Trabalho e Emprego em Saúde. IN GIOVANELLA, L et al. (Org) Políticas e Sistemas de Saúde no Brasil. Rio de Janeiro : Editora FIOCRUZ, 2011

MACHADO, MH; VIEIRA, ALS; OLIVEIRA, E. Construindo o perfil da enfermagem. Revista Oficial do Conselho Nacional de Enfermagem. Enfermagem em Foco 2012; 3(3): 119-122

MACIEL FILHO, R. E PIERANTONI, C. R. O médico e o mercado de trabalho em saúde no Brasil: revendo conceitos e mudanças. In A. F. R. Barros,(org.), Observatório de Recursos Humanos em Saúde no Brasil: estudos e análises. (Vol. 2, pp. 139-162). Rio de Janeiro: Fiocruz, 2004

MANDEL, E. O Capitalismo Tardio. Tradução Carlos E Silveira Matos, Regis de Castro Andrade e Dinah de A. Azevedo. $2^{\mathrm{a}}$ ed. São Paulo: Nova Cultural, 1985.

Marcelino LF, Patrício ZM. A complexidade da obesidade e o processo de viver após a cirurgia bariátrica: uma questão de saúde coletiva. Ciência \& Saúde Coletiva, 16(12):4767-4776, 2011.

MARX, K. O Capital- Crítica da Economia Política. São Paulo: Boitempo Editorial, Livro I, 2013.

O Capital. Crítica da Economia Política. São Paulo: Boitempo Editorial, Livro II, 2014.

A Ideologia Alemã: crítica da mais recente filosofia alemã em seus representantes Feuerbach, B. Bauer e Stirner, e do socialismo alemão em seus diferentes profetas (1845-1846). São Paulo: Boitempo,2007.

Manuscritos econômico-filosóficos.[4.reimpr.], São Paulo: Boitempo Editorial, 2010.

. Grundrisse : Manuscritos Econômicos de 1857-1858 : Esboços da Crítica

Da Economia Política / São Paulo : Boitempo ; Rio de Janeiro : Ed. UFRJ, 2011 
MARQUES, MB. Ciência, Tecnologia e Qualificação Profissional em Saúde. IN AMÂNCIO FILHO, A. MOREIRA CGB (Org.) Saúde, trabalho e formação profissional. Rio de Janeiro: FIOCRUZ, 1997.

MENDES-GONÇALVES, R. B. Medicina e História: Raízes Sociais do Trabalho Médico. Dissertação (Mestrado) - Universidade de São Paulo, São Paulo, 1979. .. Tecnologia e organização social das práticas de saúde. Características tecnológicas do processo de trabalho da rede estadual de Centros de Saúde de São Paulo [tese]. São Paulo: Universidade de São Paulo; 1994

Prefácio. In: AYRES, J. R. C. M. (org.).Epidemiologia e emancipação. São Paulo: Hucitec, 1995a, pp.13-20.

Saúde, Sociedade e História / Ricardo Bruno Mendes-

Gonçalves ; organização José Ricardo de C. M. Ayres, Liliana Santos. - 1. ed. - São Paulo : Hucitec ; Porto Alegre : Rede Unida, 2017.

MERHY, E.E. Saúde: a cartografia do trabalho vivo. $3^{\circ}$ ed. São Paulo: HUCITEC, 2007. MERHY, E.E et al.. Diálogos pertinentes: micropolítica do trabalho vivo em ato e o trabalho imaterial. Novas subjetivações e disputas por uma autopoiese anticapitalística no mundo da saúde. In COCCO, G e SIQUEIRA, M (org.). Por uma política menor: arte, comum e multidão. Rio de Janeiro, Fundação Casa de Ruy Barbosa, 2014.

MERHY, E.E ; CECILIO, LC O. Por um modelo tecno-assistencial em defesa da vida. Saúde em Debate, Londrina/PR, v. 33, p. 83-89, 1991.

MÉSZÁROS, István. A teoria da alienação em Marx. São Paulo: Boitempo editorial, 2006.

MINAYO, M. C. S. Estrutura e sujeito, determinismo e protagonismo histórico: uma reflexão sobre a práxis da saúde coletiva. Ciência \& Saúde Coletiva, 6(1): 7-19, 2001

MILLS, C.W. A Nova Classe Média (White Collar). Tradução de VERA BORDA, Rio de Janeiro, 1969.

MORIN, E. Introdução ao Pensamento Complexo. 3. ed. Porto Alegre: Sulina, 2007

NAVARRO, V. Medicine under capitalism. Nova York: Prodist, 1976, pp. 33-66 
NICHOLS T et al.. Factory regimes and the dismantling of established labor in Asia: a review of cases from large manufacturing plants in China, South Korea and Taiwan. Work Employment \& Society, Dec 2004, Volume: 18 Issue: 4 pp.663-685.

NOGUEIRA, R.P. A Força de Trabalho em Saúde. Revista de Administração Pública., Rio de Janeiro, 17(3):61-70. jul./set. 1983

Pessoal de saúde: a discussão teórica e a produção científica sobre o tema. In: Nunes, E. D. Nunes ED. As ciências sociais em saúde na América Latina: tendências e perspectivas. Brasília (DF): OPAS; 1985

As Dimensões do Trabalho Em Saúde. . IN AMÂNCIO FILHO, A. MOREIRA CGB (Org.) Saúde, trabalho e formação profissional. Rio de Janeiro: FIOCRUZ, 1997.

O trabalho em saúde: novas formas de organização. In: NEGRI, B.; FARIA, R. \& VIANA, A. L. D. (Orgs.) Recursos Humanos em Saúde: política, desenvolvimento e mercado de trabalho. Campinas: Unicamp/IE, 2002. . A saúde pelo Avesso, Natal, RN: Seminare, 2003. 260p.

.A Segunda Crítica Social da Saúde de Ivan Illich Revista Interface Comunic, Saúde, Educ, v7, n12, p.185-90, fev 2003

- Introdução ao Estudo do Capital nos Serviços de Saúde. In NOGUEIRA, R. P e GOMES, R. M. Capitalismo e Saúde. Rio de Janeiro: CEBES, 2012

NUNES, E. D. Cecília Donnangelo: pioneira na construção teórica de um pensamento social em saúde. Ciênc. saúde coletiva, Rio de Janeiro , v. 13, n. 3, p. 909-916, June 2008. Available from <http://www.scielo.br/scielo.php?script=sci_arttext\&pid=S141381232008000300013\&lng=en\&nrm=iso>. access on $15 \quad$ Sept. 2018. http://dx.doi.org/10.1590/S1413-81232008000300013.

Texto e Contexto: A Prática Médica Como Trabalho. A narrativa de RB Mendes-Gonçalves ( In Saúde, Sociedade e História / Ricardo Bruno MendesGonçalves ; organização José Ricardo de C. M. Ayres , Liliana Santos. - 1. ed. - São Paulo : Hucitec ; Porto Alegre : Rede Unida, 2017.

OHNO, T. Toyota Production System: Beyond Large Scale Production. Productivity Press, New York. 1988 
OLIVEIRA FILHO, J-J. Patologias e regras metodológicas, São Paulo, Estudos Avançados USP- Vol9, n²3, Jan/Abril 1995, p 263-268

PAIM, J.S Recursos humanos em saúde no Brasil: problemas crônicos e desafios agudos. São Paulo, Faculdade de Saúde Pública/USP, 1994.

PEDUZZI, M. Equipe multiprofissional de saúde: a interface entre trabalho e interação. Tese de Doutorado. Faculdade de Ciências Médicas - FCM, Universidade Estadual de Campinas, São $1999 . \quad$ Paulo, Disponível http://www.bibliotecadigital.unicamp.br/document/?code=vtls000186836.

Equipe multiprofissional de saúde: conceito e tipologia. Revista de Saúde Pública 2001;35(1):103-9.

. Trabalho em equipe de saúde da perspectiva de gerentes de serviços de saúde: possibilidades da prática comunicativa orientada pelas necessidades de saúde dos usuários e da população. 2007. Tese (Livre Docência em Gestão de Recursos Humanos em Saúde e Enfermagem) - Escola de Enfermagem, Universidade de São Paulo, São Paulo, 2007. Disponível em: <http://www.teses.usp.br/teses/disponiveis/livredocencia/7/tde-02072009-105425/>. Acesso em: 2017-01-16

PEDUZZI, M. e ANSELMI M.L. O processo de trabalho de enfermagem: a cisão entre planejamento e execução do cuidado. Revista Brasileira de Enfermagem, Brasília, v. 55, n. 4, p. 392-398, jul./ago. 2002

PEDUZZI, M. e SCHRAIBER, L. Processo de Trabalho em Saúde. Verbete do Dicionário da Educação Profissional em Saúde. Fundação Oswaldo Cruz. Escola Politécnica de Saúde Joaquim Venâncio, Rio de Janeiro, 2009. Disponível em: http://www.sites.epsjv.fiocruz.br/dicionario/verbetes/protrasau.html

PEREIRA, L. Ensaios de Sociologia do Desenvolvimento. São Paulo, Livraria Pioneira Editora, 1970.

PEREIRA, L. D. A Gestão da Força de Trabalho em Saúde na Década de 90. PHYSIS: Revista de Saúde Coletiva,, 14(2), 19, 2004.

PIERANTONI, C.R. As reformas do Estado, da saúde e recursos humanos: limites e possibilidades. Ciência \& Saúde Coletiva, 6(2):341-360, 2001 
PIRES, D. Reestruturação produtiva e trabalho em saúde no Brasil. São Paulo, Annablume. 2007.

PIRES, D. Reestruturação produtiva e trabalho em saúde no Brasil. São Paulo, Annablume. 2007.

Divisão Técnica do Trabalho em Saúde. Verbete do Dicionário da Educação Profissional em Saúde. Fundação Oswaldo Cruz. Escola Politécnica de Saúde Joaquim Venâncio, Rio de Janeiro, 2009a. Disponível em:http://www.epsjv.fiocruz.br/dicionario/verbetes/divtectrasau.html

PIRES, D et al.. Organização do Trabalho em Enfermagem: Implicações no Fazer e Viver dos Trabalhadores de Nível Médio. Revista Trabalho, Educação e Saúde, v. 2 n. 2, p. 311$325,2004$.

.Inovação tecnológica e cargas de trabalho dos profissionais de saúde: revisão da literatura latino-americana. Revista Eletrônica de Enfermagem. [Internet].UFG;12(2):373-9. 2010.

POLACK, J. La Médicine du Capital. Paris, Maspero, 1972.

POULANTZAS, N. Poder político e classes sociais. São Paulo: Martins Fontes, 1977.

QUEIROZ, V. M. de; SALUM, M. J. L. Globalização econômica e a apartação na saúde: reflexão crítica para o pensar/fazer na enfermagem. Trabalho apresentado no $48^{\circ}$ Congresso Brasileiro de Enfermagem. São Paulo, 1996

RATTNER, H. Tecnologia e Sociedade. Editora Brasiliense, São Paulo, 1980.

RÊGO, E. Do Gatt à OMC: O que Mudou, como Funciona e para onde Caminha o Sistema $\begin{array}{lllll}\text { Multilateral de } & \text { Comércio, } & 1996 & \text { disponível }\end{array}$ http://www.bndespar.gov.br/SiteBNDES/export/sites/default/bndes_pt/Galerias/Arquivo s/conhecimento/revista/gatt.pdf. Acessado em 15/12/2013 as 3h30

RIBEIRO, G. Afinal, o que a organização mundial do comércio tem a ver com a educação superior? Revista Brasileira de Política Internacional. 49 (2): 137-156, 2006.

ROUANET, As Razões do Iluminismo, São Paulo, EDITORA SCHWARCZ LTDA.1998 
SADER, E. Quando novos personagens entraram em cena: experiências, falas e lutas dos trabalhadores da Grande São Paulo, 1970-80. Rio de Janeiro: Paz e Terra, $4^{a}$ edição 2001. SAES, D. "A Questão da Autonomia Relativa do Estado em Poulantzas". Crítica Marxista, $\mathrm{n}^{\circ}$ 7, pp. 46-66, (1998).

SCHMITZ, A. A.. Max Weber e a corrente neoweberiana na sociologia das profissões. Em Tese, Florianópolis, v. 11, n. 1, p. 10-29, jul. 2014. ISSN 1806-5023. Disponível em: <https://periodicos.ufsc.br/index.php/emtese/article/view/1806-5023.2014v11n1p10>. Acesso em: 05 set. 2018. doi:https://doi.org/10.5007/1806-5023.2014v11n1p10.

SCHRAIBER, L. B. Educaçäo médica e capitalismo: um estudo das relações: educação e prática médica na ordem social capitalista. Säo Paulo; HUCITEC; 1989. 133 p. (Saúde em Debate, 27).

.O Médico e seu Trabalho. Limites da liberdade. São Paulo: Hucitec, 1993. O médico e suas interações: a crise dos vínculos de confiança. São Paulo: Hucitec, 2008.

SCHRAIBER, L.B et al. Planejamento, gestão e avaliação em saúde: identificando problemas. Ciênc. saúde coletiva [online]. 1999, vol.4, n.2, pp.221-242. ISSN 14138123. http://dx.doi.org/10.1590/S1413-81231999000200002.

SCHRAIBER, Lilia Blima; MOTA, André. O social na saúde: trajetória e contribuições de Maria Cecília Ferro Donnangelo. Ciênc. saúde coletiva, Rio de Janeiro , v. 20, n. 5, p. 1467-1473, May 2015 . Available from $<$ http://www.scielo.br/scielo.php?script=sci_arttext\&pid=S141381232015000501467\&lng=en\&nrm=iso>. access on $15 \quad$ Sept. 2018. http://dx.doi.org/10.1590/1413-81232015205.00482015.

SENNET, R. O Declínio do Homem Público: as tiranias da intimidade. São Paulo; Companhia das Letras, 1989

SOUZA, H. A interpretação do trabalho em enfermagem no capitalismo financeirizado: um estudo na perspectiva teórica do fluxo tensionado. 2015. Dissertação (Mestrado em Serviços de Saúde Pública) - Faculdade de Saúde Pública, Universidade de São Paulo, 
São Paulo, 2015. Disponível em: <http://www.teses.usp.br/teses/disponiveis/6/6135/tde20012015-100501/>. Acesso em: 2015-08-13.

SOUZA, HS; MENDES, AN. A terceirização e o "desmonte" do emprego estável em hospitais. Rev. esc. enferm. USP, São Paulo, v. 50, n. 2, p. 286-294, abr. 2016 . Disponível em <http://www.scielo.br/scielo.php?script=sci_arttext\&pid=S008062342016000200286\&lng=pt\&nrm=iso>. acessos em 19 jan. 2017. http://dx.doi.org/10.1590/S0080-623420160000200015.

SOUZA, H. S.; MENDES, A. N. (Org.). Trabalho e Saúde no Capitalismo Contemporâneo: Foco em Enfermagem. Editora Doc Content, Rio de Janeiro, $1^{\text {a }}$ Edicão, 2016

TARTUCE, G. Algumas Reflexões sobre a Qualificação do Trabalho a partir da Sociologia Francesa do Pós-Guerra. Revista Educ. Soc., Campinas, vol. 25, n. 87, p. 353382, maio/ago 2004.

THOMPSON, EP.A Miséria da Teoria ou Um Planetário De Erros: uma crítica ao pensamento de Althusser. Zahar Editores, Rio de Janeiro, 1981

VIEIRA-DA-SILVA, L.M. Gênese Sócio-Histórica da Saúde Coletiva no Brasil. In: LIMA, N.T.,SANTANA, J.P., and PAIVA, C.H.A., orgs. Saúde coletiva: a Abrasco em 35 anos de história [online]. Rio de Janeiro: editora FIOCRUZ, 2015, pp. 25-48. ISBN: 978-85-7541-590-0. Available from: doi: 10.7476/9788575415900.0003. Also available in ePUB from: http://books.scielo.org/id/q4gzb/epub/lima-9788575415900.epub.

VIEIRA-DA-SILVA LM, PAIM JS, SCHRAIBER LB. O que é Saúde Coletiva IN: PAIM JS, ALMEIDA FILHO N (orgs). Saude Coletiva. Teoria e Prática. Rio de Janeiro: MedBook , 2014. p.3-12

VILLERMÉ LR. Reseña del estado físico y moral de los obreros de las industrias del algodón, la lana y la seda. En: Buck C, Llopis A, Nájera E, Terris M, eds. El desafío de la epidemiología. Washington DC: Organización Panamericana de la Salud; 1988. 
VITA L. Apogeo y crisis de la ciudadanía de la salud: Historia del derecho a la salud en el siglo XX. Salud colectiva [Internet]. 2012 [citado 11 nov 2016]; 8(3): 337-340. Disponible en: http://www.scielo.org.ar/scielo.php?script=sci_arttext\&pid=S1851$\underline{82652012000400010 \& \operatorname{lng}=\mathrm{es} \& \mathrm{nrm}=\mathrm{iso}}$

WEBER, M. A ética protestante e o espírito do capitalismo. São Paulo: Companhia das Letras. 2013.

ZHANG, XUEYAN \& WANG, ZHONGXU \& LI, TAO. (2010). The current status of occupational health in China. Environmental health and preventive medicine. 15. 263-70. 10.1007/s12199-010-0145-2. 